\title{
Respectable Women, Ambitious Men: Gender and Family Networks in Victorian Sheffield
}

\author{
Autumn Mayle \\ aumayle@mix.wvu.edu
}

Follow this and additional works at: https://researchrepository.wvu.edu/etd

Part of the European History Commons, History of Gender Commons, History of Religion Commons, and the Women's History Commons

\section{Recommended Citation}

Mayle, Autumn, "Respectable Women, Ambitious Men: Gender and Family Networks in Victorian Sheffield" (2020). Graduate Theses, Dissertations, and Problem Reports. 7530.

https://researchrepository.wvu.edu/etd/7530

This Dissertation is protected by copyright and/or related rights. It has been brought to you by the The Research Repository @ WVU with permission from the rights-holder(s). You are free to use this Dissertation in any way that is permitted by the copyright and related rights legislation that applies to your use. For other uses you must obtain permission from the rights-holder(s) directly, unless additional rights are indicated by a Creative Commons license in the record and/ or on the work itself. This Dissertation has been accepted for inclusion in WVU Graduate Theses, Dissertations, and Problem Reports collection by an authorized administrator of The Research Repository @ WVU.

For more information, please contact researchrepository@mail.wvu.edu. 
Respectable Women, Ambitious Men: Gender and Family Networks in Victorian Sheffield Autumn Mayle

Dissertation submitted to the Eberly College of Arts and Sciences at West Virginia University In partial fulfillment for the requirement for the degree of Doctorate in History

\author{
Katherine Aaslestad, Ph. D., Chair \\ Joseph Hodge, Ph. D. \\ Matthew Vester, Ph. D. \\ Marilyn Francus, Ph. D. \\ Alison Twells, Ph. D. \\ Department of History
}

\author{
Morgantown, West Virginia
}

2020

Keywords: philanthropy, domesticity, Victorian England, nineteenth-century Sheffield, family business, kinship, women and gender

Copyright 2020 Autumn Mayle 


\begin{abstract}
Respectable Women, Ambitious Men: Gender and Family Networks in Victorian Sheffield Autumn Mayle
\end{abstract}

"Respectable Women, Ambitious Men: Gender and Family Networks in Victorian Sheffield" offers a family study of Nonconformist manufacturers in nineteenth-century Sheffield through several thematic case studies on such subjects as gender, family networks and businesses, bankruptcy, piety, and charitable work. This project focuses on the Reads, a family of middleclass Congregationalist smelters who owned a smelting works, named Read \& Co., in nineteenth-century Sheffield. The Reads' experiences contribute to recent scholarship on gender and kinship studies by addressing the role of nineteenth-century conceptions of masculinity and femininity on family, charity, and business and the enduring influence of nuclear families and family networks in modern Europe. Analyzing the Reads' family network demonstrates that families utilized these structures to sustain and promote their businesses and philanthropic work during periods of financial crisis. The Reads' charitable activism also reveals the integral role of inward religion and piety within their philanthropic ventures - aspects that many other studies of middle-class charity dismiss as primarily representations of middle-class respectability, social authority, and self-interest. 
Table of Contents

Acknowledgements iv

Introduction 1

Map $1 \quad 38$

$\begin{array}{ll}\text { Chapter } 1 & 39\end{array}$

$\begin{array}{ll}\text { Map } 2 & 74\end{array}$

Read Family Tree $\quad 75$

$\begin{array}{ll}\text { Chapter } 2 & 76\end{array}$

Chapter $3 \quad 118$

$\begin{array}{ll}\text { Chapter } 4 & 147\end{array}$

Chapter 5 177

Conclusion 215

Bibliography 224 
Acknowledgements

I owe sincere thanks and gratitude to the many colleagues who I have been fortunate enough to be mentored, inspired, and encouraged by. Special thanks first and foremost to my dissertation chair and advisor, Katherine Aaslestad, whose patience, guidance, encouragement, and feedback carried me through the exciting and stressful periods of graduate coursework, candidacy, and dissertating. I would also like to thank the other members of my dissertation committee, Matthew Vester, Joseph Hodge, Marilyn Francus, and Alison Twells who supported my project and offered constructive and inspiring feedback. Of these four, special regard is due to Matthew Vester, who offered insightful comments and suggestions on various chapters, and Alison Twells, who showed kind interest and support for work that was largely inspired by her own.

I was also fortunate to receive support and encouragement while conducting archival research in England. Special thanks to local historian and fellow Read-enthusiast, Penny Rea, who was kind enough to invite me to participate in her vital and inspiring work that honored the Read family's legacy and whose discussions about the Reads' and Wilsons' roles in local history helped to shape this project. I also owe a great debt of gratitude to Tim Knebel and the staff at the Sheffield City Archives and Local History Library for their help and support. Thanks also to the archivists and librarians at the Sheffield University Archives, Nottingham Archives, Dr. Williams' Library, and the Evangelical Library. Thanks, finally, to West Virginia University's History Department, Women and Gender Studies Department, Humanities Department, and Eberly College of Arts and Sciences without whose generous grants and fellowships this research would not have been possible. 
Introduction

Many of these records would be considered trivial and egotistical to strangers, but they are intended to be read by my own Family only, to whom references to ourselves will not be altogether devoid of interest. I wrote to amuse myself; and began to arrange my recollections interspersed with Montgomery's letters, at the suggestion of my Elizabeth. They were for her-Who will care for them now-M.A.R. ${ }^{1}$

Though Mary Anne Rawson alleged that she only wrote the "Memorials of James Montgomery" for her "amuse[ment]," the text makes it clear that she deemed her family's contributions as important parts of the community's history. Mary Anne's decision to create her own, in her opinion, more accurate biography on James Montgomery's life that presented not only his achievements, but his personality and interests, evidences her belief in the importance of her family's perspective on the life of this great man..$^{2}$ It is telling that Mary Anne's depiction of Montgomery's life was not so much the story of Montgomery as the story of her family's relationship with him — to the extent that she caught herself digressing from Montgomery's story while relating details about her family's lives. What's more, Mary Anne's self-conscious humility on its content and her final, tragic note on her daughter, Lizzie Rawson's, early death, bely her earlier comment on the project only being written for the family-her ongoing compilation of these recollections proved her conviction that they should be preserved. Like Mary Anne's “Memorials of James Montgomery," this project seeks to reintroduce her family’s lives into the local and national narrative of British nineteenth-century history.

\footnotetext{
${ }^{1}$ Mary Anne Rawson, “Memorials of James Montgomery,” James Montgomery Collection, (hereafter JMC) Sheffield University Archives (hereafter SUA).

2 Ibid.
} 


\section{Methodology and Notes on Primary Sources}

This project provides a series of case studies drawing on the Reads' lives to reveal insights into the role of gender, family networks, kinship ties, and middle-class morality in family businesses and charitable endeavors. In effect, this dissertation acts as a blend between a microhistory and a family study: a study of the Reads that unveils how their experiences reflect their worldviews as Nonconformist, manufacturing men and women in nineteenth-century Northern England and the role of this community within British history. My work uses a combination of microhistory and family studies to analyze how individuals in the family worked together by studying their personal correspondence and diaries to determine the individual's gendered, familial role in the family network. The Read's family network sheds light on problematic assumptions in the current historical narrative: an overshadowing emphasis on marriage, motherhood, and fatherhood in family history and fiscal success and expansion in studies of manufacturing in the era of industrial capitalism. This study explores broader notions of family, the experiences of bankruptcy and financial crisis, and commitments to philanthropic activism through the perspective of gender and family networks.

My project contributes to gender scholarship by examining how men and women in the Read family worked together using their gendered, kin roles to support the family business and pursue meaningful charitable work; revealing that each sex performed certain tasks or held specific responsibilities according to contemporary ideas about masculinity and femininity. Likewise, it reacts to seminal works of family history that highlighted the enduring influence of family networks and kinship ties into the modern era by presenting the Reads as yet another example of families that heavily relied upon their kinship networks to sustain their professional and philanthropic interests. 
My work also reflects a theme in scholarship that connects middle-class associational life and charitable work in civil society with the creation of a middle-class identity that asserted its influence within the community as moral authorities. The Reads engaged in many causes that championed middle-class morality as the solution to public evils-anti-slavery, poor relief, temperance, and lower-class education. As other works on middle-class charitable endeavors have shown, these enterprises were rife with inherent power relationships. Regardless of the middle classes' 'good intentions', a larger ideological narrative of superior civilized cultures and inferior "heathen" cultures ensured that these projects aggrandized middle-class norms at the expense of those receiving their aid. ${ }^{3}$

This project acknowledges that middle-class charitable work enabled them to assert social and moral authority over the lower classes. Yet, it aims to reconcile this narrative of social power and local authority with the Reads' visceral Christian piety and authentic morality. My purpose, however, is not to idolize or exalt the Reads' charitable work, but to reintroduce the crucial role of personal religious and moral sentiments in these projects by studying how individual and collective remarks on their faith influenced their religious impulses to minister to their family members as well as the lower classes. In order to uncover these themes, this thesis relies heavily on the Reads' personal papers and correspondence.

The Mary Anne Rawson Collection and Sheffield Smelting Company Collection at the Sheffield City Archives features an extensive array of family correspondence, personal journals, public records and business papers. These sources serve as crucial tools in revealing the story of a family who - though recognized by their contemporaries as a prominent family of community leaders and activists-- did not appear in the contemporary press or other public documents. And,

\footnotetext{
${ }^{3}$ Alison Twells, The Civilising Mission and the English Middle Class, 1792-1850: The Heathen at Home and Overseas (Palgrave Macmillan, 2009), 10-11.
} 
who remained marginal in the national and even local history of nineteenth-century England.

Alison Twells' and Claire Midgley's seminal works, which heavily inspired this project, are the exception. ${ }^{4}$ Without their pioneering studies of the family's letters and papers, the Reads would be lost to history.

In addition to serving as the foundational primary source material available on the Reads' experiences, these letters and family documents also provide necessary details and context unavailable from other types of primary sources, such as the press or government documents. As the scope of this thesis focuses largely on gender and family, personal correspondence offers crucial insights into individual roles, opinions, and experiences. These sources are especially important for insights into the lived experiences of middle-class women. Unlike studies of aristocratic or royal women, there are not traces of these women's lives available through primary sources that demonstrate popular culture like political cartoons, government officials' reports, or political broadsheets. What's more, letters and diaries allow a vantage point into these figures' personal thoughts and representations of their lives and opinions to others. These primary sources therefore enable scholars to address the experience of men and women who represented a social class rising in prominence and influence during the eighteenth and nineteenth centuries whose voices would otherwise be lost and absent in the historical record.

\footnotetext{
${ }^{4}$ Twells, The Civilising Mission and the English Middle Class; Alison Twells, 'We Ought to Obey God Rather than Man': Women, Anti-Slavery, and Nonconformist Religious Cultures, 1800-1840," in Women, Dissent, and AntiSlavery in Britain and America, 1790-1865, eds. E. J. Clapp and J .R. Jeffrey (Oxford: Oxford University Press, 2011); Alison Twells, "Missionary Domesticity, Global Reform, and the 'Woman's Sphere' in Early NineteenthCentury England," Gender and History 18, no. 2 (2006): 266-84; Alison Twells, 'Let Us Begin Well at Home': Class, Ethnicity, and Christian Motherhood in the Writing of Hannah Kilkam, 1774-1833," in Radical Femininity: Women's Self-Representation in the Public Sphere, ed. Eileen Yeo (Manchester: Manchester University Press, 1998); Clare Midgley, Women Against Slavery: The British Campaigns, 1780-1870 (London: Routledge, 1992). David Price's book, Sheffield Radicals, also merits mention for its recognition of the Reads' engagement in radical politics in the late eighteenth century and Mary Anne's involvement in the Anti-Slavery movement. See David Price, Sheffield Trouble Makers: Rebels and Radicals in Sheffield History (Andover, Hampshire: Phillimore \& Co., 2008).
} 
That being said, relying heavily on correspondence as a primary source presents a few potential weaknesses and challenges that must be addressed. One unavoidable drawback comes from the fact that such sources are often fragmented and do not portray the entire picture. This limited framework necessarily impacts the scope of the overall project and directly determines its focus. Often only one side of the conversation is shown, the other letters unfortunately having been lost to history. In some cases, scholars assume that many pieces were destroyed by family members or descendants who felt that the items contained compromising or embarrassing details that would dishonor the family name. ${ }^{5}$ This setback requires historians to use the context of the surviving letters and the other primary source or scholarly evidence to make inferences and form arguments on these exchanges. In other words, there are places where the historian must piece together slim bits of historical evidence to make suppositions.

Another potential weakness that other scholars have raised is correspondence's viability as a tool to study individual thoughts and feelings. As many studies have admitted, letters were written in a language purposed to the individual in question's goals and circumstances.

Christopher Johnson's study addressed this by acknowledging that these sources do not offer "transparent statements of feeling;" rather they allow "people [to] represent themselves... as they wish to be seen, as they want to be recognized." ${ }^{\prime 6}$ Likewise, in her work on nineteenth-century women, Kathryn Gleadle clarified that she used women's letters and diaries not primarily as "transparent indicators" of their lived experience, but as a way to understand how women shared

\footnotetext{
${ }^{5}$ Christopher H. Johnson, Becoming Bourgeois: Love, Kinship, and Power in Provincial France, 1670-1880 (Ithica: Cornell University Press, 2015), 2.

${ }^{6}$ This comment is a quote from advice that Joan Wallach Scott offered the author on the pitfalls of using correspondence as a central primary source. See Johnson, 5. See also Sarah Horowitz, Friendship and Politics in Post-Revolutionary France (University Park, PA: Penn State University Press, 2014), 11; Denise Z. Davidson, "The New (Emotional) Regime: Bourgeois Reactions to the Turmoil of 1814-1815," French History Studies 42, no. 4, (2019): 595-621, 596, 601.
} 
their interests with others and fashioned themselves. ${ }^{7}$ These examples demonstrate that even if all the letters had survived scholarly interpretation and analysis would still demand that the historian make inferences about biases, true objectives, and thought processes which are hidden among the pages due to constrictions of propriety, pragmatism, or cultural conventions. In order to address this complication, scholars like William Reddy study the manipulation or communication of emotions in "emotives" (words and gestures) to trace the conventionalization of certain tropes—or "emotional regimes." 8

Some scholars also question the utility of correspondence as accurate reflections of lived experiences due to the common convention of writing in form - using standard models of writing and responding; they argued that the prevalence of these epistolary practices obscured any true representation of family life and only showed idealized family relationships and tropes of civility. ${ }^{9}$ For example, Horowitz's work argued that individuals often used emotional language such as the "salutation" "mon cher ami" as a "formula" or matter of convention—or more compellingly— " for strategic purposes." ${ }^{10}$ My work responds to this point by arguing that though subterfuge may be involved in these representations of family life, analyzing these letters to uncover strategies and hidden agendas in letters permits historians to illuminate contemporary thoughts about family, love, emotion, etc. In other words, by unpacking these letters one can get a glimpse of reality — the situation correspondents are trying to change or protect-and the ideal grasped for-their advice, suggestions, or concerns that point towards a higher goal. Though we cannot prove the validity of one person's feelings for another, my project is most concerned with

\footnotetext{
${ }^{7}$ Kathryn Gleadle, Borderline Citizens: Women, Gender, and Political Culture in Britain, 1815-1867 (Oxford: Oxford University Press, 2009), 15.

${ }^{8}$ See William Reddy, The Navigation of Feeling: A Framework for the History of Emotions (Cambridge: Cambridge University Press, 2001). For more on the utility of Reddy's work, see Davidson, 598.

${ }^{9}$ Johnson, 2; Horowitz, 11.

${ }^{10}$ Horowitz, 11.
} 
the strategy or reasoning behind why these figures evoked this language of feelings and affection in their letters. ${ }^{11}$

The Mary Anne Rawson Collection and family papers in the Sheffield Smelting Company Collection appear to be exceptional in terms of primary sources on family history in public archives. Like Johnson's study of the Galles in mid-eighteenth to mid-nineteenth century France, this project benefits from a prolific number of letters that discuss family matters in intimate detail, particularly concerning women's roles in the network. ${ }^{12}$ The Reads' letters offer direct references to the family's daily lives, reveal quarrels and tensions between family members, and refer to unsavory topics like the threat of promiscuity within the community as well as gossip about neighbors. ${ }^{13}$

\section{Introduction to the Family}

My dissertation focuses on the generation of Mary Anne Rawson and her siblings Eliza Wilson, Catherine Read, Emily Read, and Edmund Read as adults (1820-1860). A brief summary of the family history establishes a crucial overview for the following chapters. The father of these siblings, Joseph Read, was the eldest son of John Read (hereafter Grandfather John) and the brother of John (hereafter Uncle John) and Anne Read. In 1795, Grandfather John made Joseph partner in the family smelting business, Read \& Co., which he had established with his maternal uncle in $1760 .{ }^{14}$ Joseph married Elizabeth Smith in 1800 and the couple had five daughters-Mary Anne, Eliza, Catherine, Emily, and Sarah — and a son, Edmund. As the owner of the family business, Joseph earned sufficient profits to move his family from the smoky,

\footnotetext{
${ }^{11}$ Horowitz makes a similar argument. See page 11.

12 Johnson, 1.

13 Other scholars have argued that such accounts are rare. See Johnson, 2-3; Horowitz, 14.

${ }^{14}$ Before 1824, the family business was named Read \& Lucas Co., however, due to this project's focus on the period when the company was called Read \& Co., this project will simply refer to it as Read \& Co. for the sake of simplicity. R.E. Wilson, Two Hundred Precious Metal Years: A History of the Sheffield Smelting Company Limited 1760-1960 (London: Ernest Benn Limited, 1960), 57.
} 
industrial conditions of the works at Green Lane to a farm in Attercliffe's countryside in c. 1814 and purchased the country estate, Wincobank Hall in $1816 .{ }^{15}$ At Wincobank Hall, the Reads lived the type of lives expected for wealthy middle-class families as evidenced by their allotment of thirty five pounds a year alone for several servants' wages; ownership of horses and carriages; subscriptions to newspapers and shares in the Yorkshire Coal Mines; and the many notable guests they entertained in their home, such as members of the landed elite like the Duke of Norfolk and their famous "friends" James Montgomery, George Bennet, Robert Moffat, and Joseph and Ann Taylor Gilbert. ${ }^{16}$ Despite their wealth and status, the Reads dedicated themselves to religious worship, charitable work, and faith outreach.

The Reads' lifestyle conforms with the narrative of middle-class manufacturer Congregationalist evangelicals in the nineteenth century who had a reputation for deep personal piety and philanthropic activism. ${ }^{17}$ Joseph's wife, Elizabeth, played an especially pivotal role in the family's religious and philanthropic ventures. She personally shepherded her children's religious development and personal piety by "read[ing] to them from the Bible, pray[ing] with them, and encourag[ing] them to care for others. ${ }^{18}$ In addition to the daily domestic practices of their faith, the Reads attended Sunday services at the Congregationalist church, Attercliffe Chapel.

Though the Reads were dedicated, active members of Attercliffe Chapel's congregation, the family feared that the long distance and "strenuous" journey to the only chapel available in their community dissuaded the rural poor in the nearby village from attending church services.

\footnotetext{
${ }^{15}$ Wilson, Two Hundred Precious Metal Years, 64, 69-70; Norma Taylor, "The Life of Mary Anne Rawson," (Sheffield University: unpublished BA dissertation, 1972), 3.

16 Taylor, "Life of Mary Anne Rawson," 3.

${ }^{17}$ Meacham Standish, “The Evangelical Inheritance,” Journal of British Studies 3, no. 1 (1963): 88-104, 89, 91.

18 Taylor, "Life of Mary Anne Rawson," 4.
} 
The Reads remedied this setback by establishing a community chapel in their carriage house at Wincobank Hall in 1817. The Wincobank villagers took advantage of this opportunity and the chapel's success spurred the Reads' eldest daughters, Mary Anne and Eliza, to start holding Sunday School classes for the neighborhood children in the family's laundry room. In addition to serving as a Sunday School teacher, Mary Anne also engaged in religious outreach by hosting cottage meetings, conducting home visits, handing out religious tracts, reading to the poor, and teaching them to read and write. ${ }^{19}$

The Read women served as religious models and charitable benefactors within their community. Once again, their mother, Elizabeth, took the lead in these endeavors. She encouraged them to "care for others" by having her daughters fashion "pincushions" that they sold to provide donations to the poor and took the girls on visits to needy families where they provided them with gifts of produce from their garden. ${ }^{20}$ Their generosity was especially necessary in the three years after 1816 when climate abnormalities and exceptional rainstorms led to crop failures, famine, and rising food prices across Britain. ${ }^{21}$ For example, in February 1817, a time of economic "distress... beyond what [Elizabeth] ha[d] ever witnessed," the Reads escalated their charitable engagement by offering gifts of beef and clothing and selling homemade baskets, dolls, needle-cases, and screens. ${ }^{22}$ This model of generosity and charitable engagement would continue to influence the Read daughters throughout their lives.

The Read family was part of a larger family network that also requires a brief introduction to explain the interconnection between the Reads, Lucases, Rawsons, and Wilsons

\footnotetext{
19 Taylor, "Life of Mary Anne Rawson," 4.

${ }^{20}$ Ibid.

${ }^{21}$ Mount Tambora erupted in Indonesia in April 1815 and disrupted weather systems across the Western hemisphere for several years. See John D. Post, The Last Great Subsistence Crisis in the Western World (Baltimore: Johns Hopkins University Press, 1977); William and Nicholas Klingaman, The Year Without Summer: 1816 and the Volcano that Darkened the World and Changed History (New York: St. Martin's Press, 2013).

22 Taylor, "Life of Mary Anne Rawson," 5.
} 
in the later chapters. The Reads and Lucases shared blood ties through Grandfather John's maternal line. Grandfather John assembled financial resources with his maternal uncle, Samuel Lucas, to start Read \& Co. in 1760 . The Lucases played an integral role in the early years of the company as Samuel Lucas' son and grandson, also named Samuel Lucas, served as partners alongside Joseph and Uncle John until they decided to dissolve their partnership with the Reads in 1824. According to R. E. Wilson, the Lucases left Read \& Co. because the company could not offer Samuel Lucas II's youngest son, William Lucas, a position. After departing Read \& Co., the Lucases formed a partnership with Samuel Lucas III's wife's family, the Shores, who also had kinship ties with the Reads. The Lucases and Shores started an enterprise in Devonshire that went bankrupt in $1831 .^{23}$

Only two of Joseph's five daughters married. Eliza married William Wilson, a Nottingham Congregationalist cotton spinning mill proprietor, in February 1829 and had seven children who survived past infancy: Mary Eliza, William Cecil, Henry Joseph, Rebecca Sophia, John Wycliffe, Catherine, and Emily Gertrude. ${ }^{24}$ Mary Anne also formed marital links with a fellow middle-class dissenter. In 1828, she married William Bacon Rawson-- a Nottingham Baptist banker and iron founder. Mary Anne's husband suffered from poor health and died in July 1829 — only eight months after the birth of their "delicate" daughter, Lizzie Rawson, in December 1828. Only four days after Mary Anne's husband died, their sister, Sarah Read, also passed. ${ }^{25}$ In addition to personal grief, the period of the 1820s also represented a period of economic hardship for the family. The French Revolutionary and Napoleonic Wars caused strains on trade that lasted long beyond 1815. Unfortunately for the members of this case study,

\footnotetext{
${ }^{23}$ Wilson, Two Hundred Precious Metal Years, 74.

${ }^{24}$ William Wilson also had a daughter from his first marriage to his maternal cousin, Sarah Morley, named Sarah Wilson. William and Eliza's second child, a son named Joseph Read Wilson, died in infancy.

${ }^{25}$ Taylor, "Life of Mary Anne Rawson," 6.
} 
1837 marked the start of a "prolonged economic depression... with ups and downs until the mid1840s." ${ }^{26}$ My study of the family examines these decades of economic decline and the family's ongoing commitment to philanthropic activism.

\section{Studies of the Middle Classes, Dissenters, and Family Networks in Northern England}

This project builds upon pivotal previous works of scholarship on the Reads by Alison Twells, Clare Midgely, and R. E. Wilson. Twells' work, The Civilising Mission and the English Middle Class, 1792-1850, linked the growth of Sheffield's philanthropic associations and auxiliary societies in the early nineteenth-century with the "newly emerging middle class," whom she called "missionary philanthropists." ${ }^{, 27}$ Her study of the middle classes in the late eighteenth- to mid-nineteenth-century argued that their engagement in "missionary philanthropy" helped to formulate middle-class identity thanks to its dependence upon regional, national, and international "networks." 28

As Twells pointed out, middle-class engagement in religious, voluntary, and philanthropic communities were an integral aspect of their larger familial, local, regional, and national networks; these communities linked them with likeminded individuals and helped them assert a common identity and culture despite disparate denominational, vocational, and regional characteristics. ${ }^{29}$ This was especially crucial for Dissenters who were denied political participation and government offices by the Test and Incorporation Acts. In addition to cementing middle-class identity, engagement in charitable work in the empire also connected

\footnotetext{
${ }^{26}$ Price, 42.

${ }^{27}$ Twells, The Civilising Mission and the English Middle Class, 4-5. Twells argued that professional and religious identities played a key role in this culture and noted it was dominated by merchants, manufacturers, clergymen, journalists, and "other professionals" and evangelical Anglicans, Baptists, Congregationalists, Methodists, as well as Unitarians and Quakers.

${ }^{28}$ Ibid., 3.

${ }^{29}$ Ibid., 5.
} 
ordinary people to the empire. Twells demonstrated that missionaries established important links between imperial interests abroad and local communities like Sheffield — in essence establishing an "imperial culture at home" through voluntary and missionary networks. ${ }^{30}$ Though this experience was empowering for the English middle classes, it was problematic in terms of ideological class power. Similarly, studies of women's anti-slavery societies in Sheffield noted how they influenced wider political and national culture through forming charitable networks and associations.

Twells' and Midgley's works demonstrated how women's use of the ideology of separate, gendered spheres influenced and empowered their engagement in anti-slavery. Twells' work on Mary Anne Rawson's abolitionism noted that though Mary Anne adhered to nineteenthcentury conceptions of femininity and domesticity, she refused to accept the Sheffield men's association's interference in her anti-slavery society's agenda. ${ }^{31}$ Furthermore, Mary Anne rejected the nineteenth-century feminist movement and demands for women's political participation because she saw herself as playing a crucial gendered role as a reformer; she did not feel unfulfilled or dissatisfied with her life or limited by domesticity rather her domestic and moral expertise legitimated her interest and engagement in charitable movements like antislavery. ${ }^{32}$

Likewise, Clare Midgley demonstrated the empowering nature of regional and national networks in her analysis of women's engagement in the British anti-slavery movement. Midgely noted that women's roles had not previously been recognized in scholarship because women's work was "primarily community based." This did not, however, mean that their efforts were

\footnotetext{
${ }^{30}$ Twells, The Civilising Mission and the English Middle Class, 10.

31 Twells, "We Ought to Obey God Rather Than Man."

${ }^{32}$ Twells, "Missionary Domesticity, Global Reform, and Women's Sphere in Early Nineteenth-Century England."
} 
"small in scale [or that they were merely] auxiliaries to local men's societies"; rather, they, like male abolitionists, served as pivotal activists in the anti-slavery movement who played gendered roles to support a national, public, political issue. ${ }^{33}$ Midgley noted how women participated in activities that were acceptable for women by adhering to their "natural" charitable, domestic, and emotive roles through engaging in "local and national abolition societies, abstaining from slavegrown produce, and writing anti-slavery verse."34

Moreover, women promoted the abolitionist cause amongst women—and legitimized their interest in national politics and economics—by purposefully using moral and emotive language to compel women to support their cause via women's "natural" familial, moral, and emotional natures. These gendered ideals and concerns justified their interest in slavery by placing them within the accepted feminine wheelhouses of women's moral, domestic, and benevolent roles as wives, mothers, and philanthropists who sought to protect slave women and children in order to obscure slavery's controversial connection to the public worlds of economics and politics. $^{35}$

Midgely represents one of the central scholars on Mary Anne Rawson's engagement in anti-slavery and the work of the Sheffield Female Anti-Slavery Society and Sheffield Ladies' Anti-Slavery Society. Her work is pivotal for its analysis of how women's gendered status legitimized their interests in anti-slavery and how their domestic, filial duties hindered their participation. My work seeks to build upon her interpretation of women's gendered roles in philanthropy by analyzing how men and women's gendered roles impacted their engagement in

\footnotetext{
${ }^{33}$ Midgley, Women Against Slavery, 3, 5.

${ }^{34}$ Ibid., 9.

${ }^{35}$ Ibid., 93, 95-6. See also Midgley, Feminism and Empire: Women Activists in Imperial Britain, 1790-1865, 20, 42, 67-8.
} 
the family business and philanthropy. Nevertheless, Midgely makes some problematic claims about Mary Anne and the Reads' lives that my work seeks to rectify and expand upon. Midgley correctly pointed out that Mary Anne's lesser domestic duties as a widowed woman with only one child (who was greatly helped by her spinster sisters) enabled her to focus on philanthropic activism. She attributes Mary Anne's father Joseph Read's wealth as a factor that permitted her to pursue this project. Yet, my research reveals that after 1834, Joseph Read experienced financial difficulties and the family moved back to the house at the mills to economize, which shows that Mary Anne continued her active philanthropic work despite the family's financial troubles. ${ }^{36}$ What's more, my work in chapters 2,3 , and 5 refutes her association of certain responsibilities-- promoting the family business and raising children — as solely the concerns of married women rather than other family members like widows or spinsters. $^{37}$

The final secondary source on the Reads that this study relied heavily upon was a study of the family business written by one of the Wilsons' descendants, R. E. Wilson. Wilson's Two Hundred Precious Metal Years' traditionalist approach and association with the family present both opportunities and challenges to this project. R. E. Wilson's work offers valuable information on the nature of the trade and the history of the company, details that are particularly valuable as a base for my own work's analysis of the business and understanding this study's supporting characters like Grandfather John, the Lucases, etc. Nevertheless, R. E. Wilson's book is a product of its time - a period of historical studies before the advent of women's history and new trends in business history. His study glorifies his forefathers as intrepid business leaders and remains completely silent on the female family members' roles in the smelting company.

\footnotetext{
${ }^{36}$ Midgley, Women Against Slavery, 74-5.

${ }^{37}$ Ibid., 81.
} 
My project also receives inspiration from and contributes to local urban histories of the middle classes in Birmingham and Leeds. Like Catherine Hall's study of Birmingham's Baptist community in Civilising Subjects, my work seeks to place the Reads within a wider middle-class Nonconformist culture in Sheffield. Catherine Hall noted that, as a center of manufacturing, Birmingham, like Sheffield, had a reputation as an grim, unpleasant place to live in the midnineteenth-century that galvanized a middle-class civic presence. ${ }^{38}$ Furthermore, both Catherine Hall's work on Birmingham and Alison Twells' work on Sheffield demonstrated the link between charitable work at home and abroad in the empire through the creation of voluntary and associational networks like anti-slavery societies and the British and Foreign Anti-Slavery Society. Hall's and Twells' studies highlighted local religious communities and associational life to show how middle-class men and women represented themselves as instructors on proper practices and used constructions of class and race to assert their authority over lower class and native peoples. ${ }^{39}$

Hall's analysis of dissenting middle-class culture in urban settings like Birmingham relates to my study on Sheffield. Civilising Subjects demonstrates that despite their "marginal" social and political status "in rapidly growing towns such as Birmingham [Nonconformists could] exert influence beyond their numbers." ${ }^{20}$ Though Hall analyzed Baptists, her point that their influence and position in local affairs stemmed from their "autonomy" and "free[dom] to interpret Scripture in their own ways, guided by the Holy Spirit" applied also to

\footnotetext{
${ }^{38}$ Chapter one will illuminate how Sheffield's unique geographical position made it both like and unlike other industrial cities.

${ }^{39}$ Catherine Hall, Civilising Subjects: Metropole and Colony in the English Imagination, 1830-1867 (Chicago: University of Chicago Press, 2002); Twells, The Civilising Mission and the English Middle Class. These scholars' focus on the impact of empire on British identity is indicative of a trend in British historiography known as the "new British history" or the "new imperial history." See also, Kathleen Wilson, Sense of the People: Politics, Culture, and Imperialism in England, 1715-1785 (Cambridge: Cambridge University Press, 1998); Kathleen Wilson, The Island Race: Englishness, Empire, and Gender in the Eighteenth Century (New York: Routledge, 2003).

${ }^{40}$ Hall, Civilising Subjects, 290.
} 
Congregationalists; who particularly valued the individual congregation's right to control their own affairs and informed, individual interpretation of the Bible. ${ }^{41}$

Hall's work on Birmingham Baptist families also offered additional areas for expansion in this study. According to Hall, "family union" constituted a central aspect of Nonconformist life that united spouses in a partnership to further the "family and mission enterprise." 42 This project will elaborate upon this theory by demonstrating how this applied not only to husbands and wives, but also to brothers, sisters, uncles, and in-laws. This aim is particularly apt because Catherine Hall included a detailed account of Sophia Sturge's status as a spinster "partner" to her brother, the famous abolitionist Joseph Sturge..$^{43}$ Yet, Hall did not address the nonconformity of Sophia's marital status to the ideal model of wives and husbands included in her assertion on the links between Baptist families. My work integrates unmarried women and the centrality of Nonconformist religious views in its examination of family networks.

R. J. Morris' works on family networks in Leeds serves as another important localized study on the urban middle class. He emphasized religion and political affiliation as the foundation of middle-class identity and pointed to the role of women's participation in family networks as contributors. Though Morris acknowledged women's crucial services as suppliers of capital and property who advanced their family's professional and economic interests, he limited their involvement to serving as resources rather than demonstrating how women influenced and tempered family relations and family strategies. ${ }^{44}$ In contrast, my work draws on gendered analysis of inter-familial relations, charitable work, and professionalism rather than focusing on

\footnotetext{
${ }^{41}$ Hall, Civilising Subjects, 290.

${ }^{42}$ Ibid., 295-6.

${ }^{43}$ Ibid., 312.

${ }^{44}$ Robert John Morris, Class, Sect, and Party: The Making of the British Middle Class: Leeds, 1820-1850 (Manchester: Manchester University Press, 1990); R. J. Morris, Men, Women, and Property in England, 1780-1870: A Social and Economic History of Family Strategies amongst the Leeds Middle Classes (Cambridge: Cambridge University Press, 2005), 233-4.
} 
the role of capital and property in middle-class formation. Instead of highlighting the exchange of property, my study analyzes the Reads' family network through their support of the family business and philanthropy.

Finally, Morris studied the middle classes without addressing how gendered identities influenced day to day life. His work noted the large percentage of the middle classes who remained unmarried compared to the other social classes but did not analyze these individuals' experiences from a gendered perspective. In other words, he observed that single men and women could not fulfill contemporary societal models as "husbands and wives" but did not utilize gendered analysis to study how their lives were impacted by traditional models of masculinity and femininity a la domesticity. ${ }^{45}$ My research examines avenues of engagement within middle-class society and family networks beyond conventional studies of marriage and the nuclear family.

\section{Historiographical Trends: Gender, Domesticity, and the Family}

This work and many of the others mentioned above were heavily influenced by the rise of women's history, gender history, and cultural history over the past forty years. Women's history and the methods of cultural history represented a trend in scholarship that rejected the conception of class as a structure in favor of studying how identities were formed based upon constructions of one's identity. Many works of scholarship during this period analyzed how constructions of class, gender, and race shaped individual experiences and the social order. In the 1990s, scholarship shifted from women's history to gender history, as many scholars viewed women's history's focus on patriarchal oppression as too limited of a narrative and understanding of the lives of women and men. By focusing on gender, furthermore, they were able to look at

\footnotetext{
${ }^{45}$ Morris, Men, Women, and Property in England, 37-8.
} 
constructions of sex to see how and why past societies established gender differences rather than focusing exclusively on how men had restricted women's access to power.

Leonore Davidoff and Catherine Hall's Family Fortunes represented a burgeoning work of scholarship that exemplified this new understanding of how constructions like class and gender shaped individual experience, which in many ways inspired the shift to gender history. Their work demonstrated how the "middling sort" constructed a class identity by differentiating themselves from the working classes and how gendered ideas of men and women's biological and social roles impacted individual experience. Davidoff and Hall's monograph responded to the previously accepted Marxist interpretation of class as a structure and criticized these historians' oversight of the role of women and the family.

Family Fortunes inspired a pivotal trend in historical scholarship that addressed the separation of spheres ideology. Their work coincided with Joan Scott's seminal essay on gender that established a new trend in scholarship: utilizing gender analysis to determine how contemporary ideas about biological difference (i.e. womanhood and manhood) contributed to power relationships within the social hierarchy. ${ }^{46}$ Since the Enlightenment, notions of inherent biological distinctions between men and women combined with existing patriarchal religious and legal traditions to create the paradigm of separate spheres. According to this theory, industrialization and the movement of work outside of the home created two separate spaces; the masculine, public sphere of men with business, politics, and economics and the feminine, private sphere of the home and family where women were "natural" authorities on domestic life. Contemporary notions about women's inherently affectionate, caring, and emotional natures vindicated their role as overseers of familial, housekeeping, and moral matters within the home;

\footnotetext{
${ }^{46}$ Joan W. Scott, "Gender: A Useful Category of Historical Analysis," The American Historical Review 91, no. 5 (1986): 1053-1075.
} 
they also, however, barred them from engaging in public life as the very qualities that empowered their domestic roles — affection, sensitivity, and vulnerability — contradicted the norms necessary to engage in the public sphere-namely reason, strength, and determination. The ideal of nineteenth-century women, therefore, entailed providing essential supportive services for their male family members as "angel[s] of the house" who curated the home into a center of domestic comfort and moral righteousness to counteract the evils of vice, competition, and dirtiness associated with the public sphere. ${ }^{47}$

For scholars of the eighteenth and nineteenth centuries, the gendered binary of the male public sphere and feminine private sphere offered a ripe arena to study the construction of gendered identities. Davidoff and Hall's Family Fortunes addressed how middle-class men and women's gendered roles helped them to assert their position in society. For instance, it demonstrated that women continued to influence the family through providing domestic services and aid even after they stopped serving formal positions in the family business. Domesticity played a crucial role in middle-class identity formation; it created a model of family life that appealed to the middle classes because it reinforced their moral principles and social status by making middle-class women the proper models of respectable womanhood. ${ }^{48}$

In addition to middle-class women's status as domestic authorities, they also became moral authorities within families due to the influence of the Evangelical Revival. The prevalence of religiosity and middle-class morality such as notions of chastity, sobriety, and thrift placed the middle-classes as a reforming element within society who saw it as their duty to reform the

\footnotetext{
${ }^{47}$ Annette F. Timm and Joshua A. Sanborn, Gender Sex and the Shaping of Modern Europe: A History from the French Revolution to the Present Day (Oxford: Berg Publishers, 2007), 76.

${ }^{48}$ Leonore Davidoff and Catherine Hall, Family Fortunes: Men and Women of the English Middle Class 1780-1850 (London: Routledge, 1987); Timm and Sanborn, 76-77, 86; Simon Morgan, A Victorian Woman's Place: Public Culture in the Nineteenth Century (London: Tauris Academic Studies, 2007).
} 
lifestyles of vice entertained by the landed elite and the working classes. Family Fortunes and Kathleen Wilson's The Sense of the People argued that middle-class professional organizations, educational societies, philanthropic associations, and voluntary societies provided middle-class men with a venue to assert their position and power in their community as a means to prove their capability for helping the lower classes and ergo their deservedness for political participation. ${ }^{49}$ More recent scholarship, largely inspired by Family Fortunes' critical analysis of the separation of spheres, has challenged and revised some of Davidoff and Hall's assertions — such as the impact of the separation of spheres on middle-class masculinity and middle-class women's abilities to engage in philanthropy as a way to assert their civic roles. For example, John Tosh's A Man's Place concurred that domesticity not only impacted women's roles in the home but also shaped men's domestic duties and engagement in the community by dictating that men engage in the process of affectionate guidance of children and to take part in family outings and spend less time in public activities like male club life. ${ }^{50}$ Similarly to Tosh's work on men's familial roles, Karen Harvey's and Joanne Bailey's studies of masculinity noted that men's domestic duties as household authorities required them to serve as financial and managerial administrators; they supported the family and its interests, balanced the budget, and oversaw purchases of goods. ${ }^{51}$

\footnotetext{
${ }^{49}$ Davidoff and Hall, Family Fortunes, 30, 416, 419; Dror Wahrman, 'Middle Class' Domesticity Goes Public: Gender, Class, and Politics from Queen Caroline to Queen Victoria," Journal of British Studies 32, no. 4 (1993): 396-432, 400.

${ }^{50}$ John Tosh, A Man's Place: Masculinity and the Middle-Class Home in Victorian England (Yale University Press, 1999), 1, 25; John Tosh, "The Old Adam and the New Man: Emerging Themes in the History of English Masculinities, 1750-1850," in English Masculinities, 1660-1800, eds. Tim Hitchcock and Michèle Cohen (London: Routledge, 2016), 223. Davidoff and Hall's work also makes a similar claim about the role of the father in their case study of Isaac Taylor. See Family Fortunes, 329-335. See also: Simon Gunn and Rachel Bell, Middle class: Their Rise and Sprawl (London: Phoenix, 2002), 6-7; Catherine Hall, "The Sweet Delights of Home," in A History of Private Life: From the Fires of Revolution to the Great War, ed. Michele Perrot (Harvard University Press, 1990), 61-2.

${ }^{51}$ Joanne Bailey, "Masculinity and Fatherhood in England, 1760-1830," in What Is Masculinity? Historical Dynamics from Antiquity to the Contemporary World, eds. John Arnold and Sean Brady (Basingstoke, Hampshire: Palgrave Macmillan, 2011)); Karen Harvey, "Men Making Home: Domesticity in Eighteenth-Century Britain," Gender and History 21, no. 3 (2009): 520-40; Pete Newbon, The Boy-Man, Masculinity and Immaturity in the Long Nineteenth Century (London: Palgrave Macmillan, 2019), 132.
} 
Other works built upon Davidoff and Hall's analysis of middle-class women's engagement in civil society and assertion of their local authority through associational life to revitalize understandings of women's influence within the public sphere by analyzing how women's charitable work offered similar opportunities to their male counterparts. For instance, Amanda Vickery's The Gentleman's Daughter pointed out the fallacy of women's complete exclusion from the public sphere as women clearly engaged in public life through such acts of sociability as social calls and attending concerts, pleasure gardens, operas, etc. ${ }^{52}$ Other scholars examined how women's local authority in engagement and commitment to charitable works provided them with opportunities to participate in public life. Andrea Geddes Poole's Philanthropy and the Construction of Victorian Women's Citizenship showed that like middleclass men, women were able to advocate for citizenship through their engagement in charitable reform movements such as urban housing, working-class education, and the rehabilitation of prostitutes and "fallen women." Poole's and Twells' works represented a greater trend in scholarship that utilized women's engagement in philanthropy to prove that gendered conceptions of middle-class women's roles as domestic and moral authorities empowered them by legitimizing their interest in the public sphere and placing them as instructors on proper familial, moral, and religious practices to the lower classes in England and the native peoples of empire. ${ }^{53}$ These questions address how women could be public actors and members of the

\footnotetext{
${ }^{52}$ Amanda Vickery, The Gentleman's Daughter: Women's Lives in Georgian England (London: Yale University Press, 1998).

${ }^{53}$ Twells, The Civilising Mission and the English Middle Class; Twells, "Missionary Domesticity, Global Reform, and the 'Woman's Sphere' in Early Nineteenth-Century England;" Anna Geddes Poole, Philanthropy and the Construction of Victorian Women's Citizenship: Lady Frederick Cavendish and Miss Emma Cons (Toronto: University of Toronto Press, 2014). See also: Michelle Perrot, "Stepping Out," in A History of Women in the West, Emerging Feminism from Revolution to World War, eds. Genevieve Fraise and Michelle Perrot (Cambridge: Harvard University Press, 1993); Sarah Richardson, The Political Worlds of Women: Gender and Politics in Nineteenth-Century Britain (Hoboken: Taylor and Francis, 2013).
} 
community even when denied political rights. Finally, scholars like Krista Cowman revealed how middle-class women drew on their authority and experiences in their local communities as philanthropists to engage in civic membership in the community through local public offices. ${ }^{54}$ These works demonstrate that middle-class women carved out spaces of activism in the public sphere through their success in local charity work.

Like these scholars, my work has been inspired and shaped by Davidoff and Hall's Family Fortunes. Similar to their study of the Cadburys, my project analyzes the family business, and in particular, the role of men and women in the business. This thesis, however, uses the family's letters to demonstrate that even after women stopped working within the business due to the separation of work from the home, they continued to promote and influence the family business through correspondence, negotiations, and strategic planning. ${ }^{55}$ Likewise, just as Family Fortunes highlights the influence of Nonconformist (Quaker) networks, my study provides a useful comparison emphasizing the Reads' and the Taylors' shared Congregationalism and engagement in the Sunday School movement. In fact, these networks overlapped as one of the Taylors' eldest daughters, Ann Taylor Gilbert, became a personal friend and fellow female abolitionist of Mary Anne Rawson after she married the Congregationalist minister, Joseph Gilbert. ${ }^{56}$

Though the ideology of separate spheres limited women's engagement in politics and the economy, my work, like Twells', shows that even pious, respectable women used domesticity as a means to legitimate their interest in engagement in the public sphere through philanthropy,

\footnotetext{
${ }^{54}$ Krista Cowman, "Women, Locality and Politics in Nineteenth-Century Britain," in Gender in Urban Europe: Sites of Political Activity and Citizenship, 1750-1900, eds. Krista Cowman, Nina Javette Koefoed, and Karlsson Sjogren (London: Routledge, 2014), 212-213. Kathyrn Gleadle also recognized that women were key participants in local reform, or as she called it, the "parochial realm." Gleadle, 47, 61.

${ }_{55}^{55}$ Davidoff and Hall, Family Fortunes, 55-7.

${ }^{56}$ Ibid., 61, 66.
} 
religious outreach, and social reform. This study further builds upon this historiographical trend to demonstrate how the Read women used the contemporary ideal domestic setting, their home, as the site of their charitable work to enable them to use gendered ideals of women's roles to engage in philanthropy and even assume leadership in some of the family's philanthropic enterprises. Therefore, this project does not deny that women faced limitations in public life; rather, it explores the ideological barrier between the private and public by highlighting how men and women articulated and interpreted assumptions about their gendered roles in both arenas. The family's letters and diaries reveal how women maneuvered around these limitations by using the concept of domesticity to legitimize their involvement in the public worlds of philanthropy and business and how conceptions of masculinity influenced men's public and private roles as husbands and providers.

As scholars reevaluated women's history, they also turned their attention to family history. Hans Medick and David Warren Sabean, among others, challenged the binary conception that family life was based either on strategies of interest and advantage or grounded on notions of sentiment. Since both interest and sentiment became understood as social constructs, new research in the 1980s, emphasized the interplay of the nexus of obligations, responsibility, and emotions in kinship dynamics. ${ }^{57}$ Similarly, a shift in scholarship questioned Lawrence Stone's assertion of the centrality of the nuclear family in modern Western culture in The Family, Sex, and Marriage. Works by scholars like Sabean challenged the narrative of the modernization model, which linked industrialization with the rise and increasing influence of the nuclear family and the corresponding decline amongst the extended family and community relations.

\footnotetext{
${ }^{57}$ Hans Medick and David Warren Sabean, eds., Interest and Emotion: Essays on the Study of Family and Kinship (Cambridge: Cambridge University Press, 1984).
} 
David Warren Sabean's study of eighteenth- and nineteenth-century Neckarhausen was perhaps the most foundational example of works that contested Stone's nuclear family model. Sabean challenged the assumption that "obligations to extended kin" were a "liability," instead proving that generations of families established relationships that created a system of networks they used to bring together capital and resources ${ }^{58}$ For Sabean and other scholars, family networks proved that this period was actually "kinship-hot" as evidenced by families' dedication to "maintaining and developing extensive, reliable, and well-articulated structures among connected families over many generations. ${ }^{" 59}$ According to Sabean, reconfiguring notions of the family in the modern period also represented opportunities to revitalize studies of class; he argued that what past historians identified as a class identity actually developed as a result of families choosing to repeatedly engage in endogamous marriages (marriages among social equals) with the same kin groups ${ }^{60}$ My research also indicates that marriages and friendships within shared religious convictions were central to nineteenth-century middle-class networks. More recently, The Family Story by Leonore Davidoff and her co-authors represents another important study that questioned the determinist connection between the nuclear family and modernization. In their efforts to reconceptualize historic family life beyond the "single model" of the nuclear family, they explored a range of family dynamics and traced scholarly preoccupation with the nuclear family and male breadwinner to a mythical "golden age" of the

\footnotetext{
${ }^{58}$ Lawrence Stone, The Family, Sex, and Marriage (London: Harper \& Row Publishers, 1977); David Warren Sabean, Property, Production, and Family in Neckarhausen, 1700-1870 (Cambridge: Cambridge University Press, 1990); David Warren Sabean, Kinship in Neckarhausen, 1700-1870 (Cambridge: Cambridge University Press, 1998). For more on the role of family historians in displacing the modernization model, see Richard Grassby, Kinship and Capitalism: Marriage, Family, and Business in the English-Speaking World, 1580-1740 (Cambridge: Cambridge University Press, 2001).

${ }^{59}$ David Warren Sabean and Simon Teuscher, "Kinship in Europe: A New Approach to Long-Term Development," in Kinship in Europe: Approaches to Long-Term Development (1300-1900), eds. David Warren Sabean, Simon Teuscher, and Jon Mathieu (New York: Berghahn Books, 2007), 3.

${ }^{60}$ Ibid.
} 
industrial family. ${ }^{61}$ Their work identified the role of the separate spheres in constructing this false image of a prominent modern, nuclear family and addressed how this limited perspective hindered scholarship by disguising the truly complex nature of family life. ${ }^{62}$ My work addresses these points as well. The Reads' family network showed that men and women within the nuclear family cooperated with their extended kin to protect their shared business, religious, and charitable interests. In the Reads' correspondence, one finds both the strong connections of obligation and sentiment amongst extended family as well as strategies to promote the nuclear family. What's more, their experiences present an opportunity to broaden scholarship on the family. Unlike most family histories that focus on marriage and parenthood, my case study features a family in which spinsters, widows, and bachelors predominated.

\section{English Middle-Class Culture and Civil Society}

Wealthy, professional, and urban appear to sum up the popular perceptions of the Victorian middle class. Historians, however, identify several additional key characteristics: the separation of work from home, the cult of domesticity, civic and philanthropic activism, and performative engagement in the public sphere to enhance status and reputation. Scholarship on the middle class has generated a rich literature. Traditionally historians associated the rise of the English middle classes to its close relationship with expanding trade and industry. Yet, since the 1990s, scholars analyzed the middle class as more than an emerging socio-economic group by emphasizing culture, values, religion, and politics. For example, if Peter Earle attributed eighteenth-century "enterprise culture" as the force that compelled merchants, shopkeepers, and manufacturers to amass fortunes and articulate their status as a new economic elite; Robert John

\footnotetext{
${ }^{61}$ Leonore Davidoff et al., The Family Story: Blood, Contract, and Intimacy 1830-1960 (New York: Longman, 1999), 4-5, 23-5.

${ }^{62}$ Ibid., 16-18. These authors isolate the work of sociologist Talcott Parsons in establishing the "influential sociological paradigm for the family of advanced capitalism" in the 1940s and 50s. See pg. 21.
} 
Morris cited religious and political affiliation as the crux of middle-class identity; Dror Wahrman linked the birth of the (maneuverable) concept of a middle class to their reactions to late eighteenth- and nineteenth-century radical politics; and Simon Gunn highlighted the middle classes' engagement in urban high culture through the establishment of town halls, chapels, concert halls, theatres, museums, public libraries, and literary societies. ${ }^{63}$ Other important studies, addressed below, assert gender's central role in the establishment of nineteenth-century middle-class identities. ${ }^{64}$ My study of a middle-class family network in Sheffield takes a broader approach that seeks to encompass varied components—-professional goals, religion, domesticity, and philanthropy — instead of emphasizing one feature of middle-class identity over another.

Beyond identifying the origins and key characteristics of the middle classes, scholars have studied inter-class relations between the middle and lower classes. These works that explore middle-class efforts to address the social problems of the industrial era through pragmatic reform also influenced my case studies of Sheffield. Many scholarly works have shown that men and women's roles in the public sphere enabled the middle classes to address social problems and improve their communities as they simultaneously established and reinforced power relationships of class, race, and gender. These opportunities were largely reliant on enlightened ideas and discourse found in the public sphere that stimulated open discussions of contemporary public matters and social concerns. ${ }^{65}$ According to Roy Porter, these debates not only fostered a

\footnotetext{
${ }^{63}$ Peter Earle, The Making of the English Middle Class: Business, Society and Family Life in London 1660-1730 (London: Methuen London, 1989); Morris, Class, Sect, and Party; Dror Wahrman, Imagining the Middle Class: The Political Representation of Class in Britain, c. 1780-1840 (Cambridge: Cambridge University Press, 1995); Simon Gunn, The Public Culture of the Victorian Middle Class: Ritual Authority and the English Industrial City 1840-1914 (Manchester: Manchester University Press, 2000).

${ }^{64}$ For more on this, see Davidoff and Hall, Family Fortunes; Tosh, A Man's Place; Hall, Civilising Subjects; Catherine Hall, White, Male, and Middle Class: Explorations in Feminism and History (New York: Routledge, 1992); Twells, The Civilising Mission and the English Middle Class.

${ }^{65}$ James Van Horn Melton, Rise of the Public in Enlightenment Europe (Cambridge: Cambridge University Press, 2001).
} 
sense of responsibility amongst the upper classes, but also helped establish a British public culture that banded them together into social networks designed to address social problems: voluntary societies and philanthropic associations. ${ }^{66}$ Associational life had an enduring influence on the development of middle-class culture throughout eighteenth and nineteenth century Europe. Wolfgang Kashuba's work showed that contemporary norms demanded that those who wished to claim their place as a member of the middle class demonstrate an awareness of contemporary events, issues, and ideas being published and disseminated in the rising print industry. ${ }^{67}$

Lastly, middle-class identity relied on a biased comparison of themselves vis a vis the aristocracy and the working classes that alleged that the latter groups were consumed by vices such as drunkenness, adultery, fornication, and laziness. On the one hand, the middle classes characterized the aristocracy as wastrels who did not work and squandered their fortunes on lifestyles of bodily pleasure; on the other, they portrayed the working classes as a mob who was either too lazy or too immoral to protect and provide for their own families. ${ }^{68}$ This sanctification of work and morality thereby articulated the special position that the middle classes held within society and justified their demands for more power and influence within national politics. Therefore, engagement in the community via civil society - associational life, newspapers, local governing structures-- represented a crucial part of middle-class urban identity. Their participation in civil society played a vital role in the establishment of a middle-class identity in Britain.

\footnotetext{
${ }^{66}$ Roy Porter, Creation of the Modern World: The Untold Story of the British Enlightenment (London: W. W. Norton and Company, 2000), 22-3, 482.

${ }^{67}$ Wolfgang Kashuba, "German Burgerlichkeit after 1800: Culture as Symbolic Practice," in Bourgeois Society in Nineteen Century Europe, eds. Jurgen Kocka and Allen Mitchell (London: Bloomsbury Academic, 1993), 392.

${ }^{68}$ Gunn and Bell, 6-7.
} 
By the early nineteenth century, many middle-class individuals considered professionalism, philanthropy, and reform as crucial elements of their class status. The middle classes used the combined force of their work in respectable trades and their participation in charitable ventures to articulate their special social position. Their status as successful, prosperous professionals played a crucial part in their conceptions of respectability. Middle-class men obtained a sense of pride from their respectable vocations as doctors, bankers, merchants, factory owners, and manufacturers, among others, because these positions provided both respectable status and the necessary funds to support themselves and their families. ${ }^{69}$ As Penelope Corfield's and Anne Digby's works showed, the increasing association of professionalism with high levels of expertise and specialized knowledge vindicated their elevated place within the social hierarchy and the urban, public sphere by suggesting that their skills contributed to the public good. ${ }^{70}$

In the Victorian era, the English middle class seemed to epitomize economic, political, and social power. The Read family embodied these three central elements through their smelting business, civic and charitable engagement, and apparent respectability. Many studies of middleclass philanthropy have linked these enterprises to aspirations or affirmations of social power over the laboring classes. Social power was implicitly tied to reform work and even projects based on good intentions generated greater social authority for the benefactors. Though I acknowledge the social advantages tied to middle-class philanthropy, my work seeks to use the family's personal papers to reincorporate the role of devout religious convictions in middle-class charitable work. Analyzing personal papers and correspondence serves as a means to uncover

\footnotetext{
${ }^{69}$ Gunn and Bell, 27.

${ }^{70}$ Penelope J. Corfield, Power and the Professions in Britain, 1700-1850 (London: Routledge, 1995); Anne Digby, Making a Medical Living: Doctors and Patients in the English Market for Medicine, 1720-1911 (Cambridge: Cambridge University Press, 1994).
} 
how religious sentiment shaped the middle classes' engagement in philanthropy by utilizing the lens of individual beliefs and reflections rather than using charitable associations' official reports or reflections.

\section{Evangelicalism and Religion}

Concepts of middle-class moral authority and men and women's gendered roles in society stemmed from religious convictions, particularly evangelicalism in the eighteenth and nineteenth centuries. The Evangelical Revival of the eighteenth century fostered an upsurge in religiosity that inspired many middle-class families like the Reads. Evangelicals influenced by the revival sought to awake a "slumbering national church" by resolutely educating the public on the importance of the Bible - as the locus of "all spiritual truth"-- and Christ's redemption of our sins on the cross. ${ }^{71}$

Their dedication to these aims impressed upon evangelicals the importance of personal faith powered by the "vital heat of the soul itself" which was inherently inward looking and “deeply personal" as it was based on the individual's relationship with God. ${ }^{72}$ Evangelical outreach focused on four core principles-- personal conversion, faith outreach, reading the Bible, and the redemption of sinners through the crucifixion. ${ }^{73}$ These concepts fueled an evangelical culture that called all "converted Christian[s]" to aid others, especially by sharing "the gospel" and saving their community's souls. ${ }^{74}$ Convictions of the necessity of "work" in one's faith impressed upon them the necessity of not only convincing others to attend church services, but to provide 'warning, encouragement, instruction... and identify themselves with [the] spiritual

\footnotetext{
${ }^{71}$ Standish, 89; David Bebbington, Victorian Nonconformity (Bangor, Gwynedd: HEADSTART HISTORY, 1992), 12.

${ }^{72}$ Standish, 89, 91.

${ }^{73}$ Bebbington, Victorian Nonconformity, 3-5.

${ }^{74}$ D. W. Bebbington, Evangelicalism in Modern Britain: A History from the 1730s to the 1980s, (London: Routledge, 1993), 5.
} 
interest[s] [of the unsaved]. ${ }^{75}$ In other words, evangelicals believed they had a responsibility to help others and to redeem sinners.

The Evangelical Revival inspired a growth in Congregationalism in the early nineteenth century due to the increased activism of the denomination's outreach. ${ }^{76}$ Shared principles between Evangelicalism and Congregationalism, such as the importance of personal "conversion" and "the power of salvation and grace" made Congregationalists particularly active contributors in eighteenth and nineteenth-century religious life. ${ }^{77}$ Congregationalists, or Independents, represented a segment of the "Old Dissent" of the seventeenth century who were influenced by Calvinist ideas about the elect. ${ }^{78}$ By the eighteenth century, the persecutions of the seventeenth century, which had forced Independents to worship in secret, gave way to the creation of "a thriving network of chapels placed prominently on main streets."79 Throughout this century, this denomination turned away from the name Independents — which stressed the necessity of retaining freedom from "external control" - and embraced the term Congregationalists — which concentrated on the congregation's "responsibility " for "govern[ing] themselves." 80

Congregationalists' acceptance of Calvin's concept of predestination became increasingly weak over the eighteenth and nineteenth century. In the eighteenth century, Congregationalists promoted extensive religious outreach efforts because they believed that no one knew who God's elect were. Therefore, their mission became to reach as many people as possible and save

\footnotetext{
${ }^{75}$ Bebbington, Evangelicalism in Modern Britain, 11. See also, Daniel L. Brunner, "The 'Evangelical' Heart of Pietist Anthony William Boehm," in Heart Religion: Evangelical Piety in England and Ireland, 1690-1850, ed. John Coffey (Oxford: Oxford University Press, 2016), 72-3, 79-80.

76 Thompson, ed., Nonconformity in the Nineteenth Century (London: Routledge and Kegan Paul, 1972 ), 3.

${ }^{77}$ Hall, "The Sweet Delights of Home," 60-1.

${ }^{78}$ David Bebbington, Victorian Nonconformity, 6, 8.

${ }^{79}$ Ibid., 9.

${ }^{80}$ Ibid.
} 
whoever they could.$^{81}$ By the Victorian period, Congregationalists largely rejected Calvinist theology due to their conviction that it misrepresented God as a harsh and uncaring absolute authority who arbitrarily condemned some to hell and allowed others who were just "as sinful" to go to heaven; this interpretation disturbed them as it contradicted the "God of love, mercy, and forgiveness [shown in] the Bible." 82 Their elevation of the Bible over theological interpretation presents another crucial component of Congregationalism: their refusal to establish a formalized concept of a liturgy because they believed that only Scripture held spiritual truth. ${ }^{83}$

This emphasis on the Bible created a tendency for Congregationalist religiosity to focus on sermons and hymns as these mediums suited their concentration on Scriptural truth and their rejection of spiritual ritualism. ${ }^{84}$ It also related to their origins as Independents - or those who asserted the right of individual congregations to control church affairs. This desire to evade establishing a top-down infrastructure led them to avoid the development of any sense of an established sect identity because they wanted to uphold the independence of individual congregations rather than establish a centralized religious entity; these beliefs led them to champion individual, spontaneous prayer as well as educated, private interpretations of scriptural meaning. ${ }^{85}$ The culture of this religious revival amongst evangelicals and Congregationalists had an enormous impact on middle-class philanthropy as evidenced by the Reads' commitment to social outreach.

\section{Family Businesses in the Era of Industrial Capitalism}

\footnotetext{
${ }^{81}$ David Bebbington, Victorian Nonconformity, 8-9.

${ }^{82}$ Mark Hopkins, Nonconformity's Romantic Generation: Evangelical and Liberal Theologies in Victorian England (Carlisle, Cumbria: Paternoster Press, 2004), 249-50.

${ }^{83}$ Karen Dieleman, Religious Imaginaries: The Liturgical and Poetic Practices of Elizabeth Barrett Browning, Christina Rossetti, and Adelaide Procter (Athens: Ohio University Press, 2012), 19.

${ }^{84}$ Ibid., 24, 30.

85 Ibid., 29, 37, 46.
} 
Like recent works on women's engagement in philanthropy, studies of women's roles within their family networks also prove that women engaged in matters outside of their own home. R. J. Morris's work, for example, demonstrated that, regardless of laws limiting women's control over their property, family networks relied on the capital and property that their female family members could offer the network. ${ }^{86}$ Their influence within the family was not simply limited to contributing resources, however, women-- even unmarried ones-- actively sought to promote their family's interests by using their social networks to garner patronage and support the family's economic and professional goals. ${ }^{87}$ Sometimes women performed tasks directly connected to the family business. Women in the cutlery trade in Sheffield served as workers, managers, and sometimes even owners; female family members of shopkeepers aided their brothers and husbands by taking customers in their stead; and widows sometimes gained control over the family business - whether or not they had adult sons — depending upon their level of expertise and influence in the family network. ${ }^{88}$ Even genteel ladies assisted their families in business matters by performing clerical tasks for their male family members, such as reading to them or writing letters. ${ }^{89}$ Similar to the revisionary scholarship on women's participation in the public world of business, recent works on family businesses demonstrate the importance of familial ties to the administrative and financial aspects of running a company in the industrial era.

\footnotetext{
${ }^{86}$ Morris, Men, Women, and Property in England, 233.

${ }^{87}$ Alison Duncan, "Power and the Old Maid: The Never-Married Gentlewoman in Her Family, 1740-1835," Women's History Magazine 63 (2010): 11-18, 12; Ruth Larsen, "For Want of a Good Fortune: Elite Single Women's Experiences in Yorkshire, 1730-1860," Women's History Review 16, no. 3 (2007): 387-401, 396-7. ${ }^{88}$ Geoffrey Tweedale, "Backstreet Capitalism: An Analysis of the Family Firm in the Nineteenth-Century Sheffield Cutlery Industry," Business History 55, no. 6 (2013): 875-91, 888; Nancy Cox, The Complete Tradesman: A Study of Retailing, 1550-1820 (Aldershot, Hants: Ashgate, 2000), 59; Hannah Barker, Family and Business During the Industrial Revolution (Oxford: Oxford University Press, 2017), 103.

${ }^{89}$ Margaret R. Hunt, The Middling Sort: Commerce, Gender, and the Family in England, 1680-1780 (Berkeley: University of California Press, 1996), 86.
} 
Family ties were "central" aspects of the "organization" of many businesses during the Industrial Revolution because they offered protection against the challenges and risks of the market. ${ }^{90}$ In the industrial period, the rapidly expanding commercial world of business gained a bad reputation for moral depravity and dubiousness due to speculative practices. Establishing family businesses guarded against the uncertainties of the public world of business by permitting families to form professional arrangements grounded on "trust and morality" that pooled together resources and capital. ${ }^{91}$ Ties of trust not only referred to familial relations, but also included relationships with members of the same congregation or association. ${ }^{92}$ Limited sources of cash made such relationships crucial in the early and mid-nineteenth century.

Most commonly, individuals looking to establish a business relied upon their familial networks or social ties to borrow the capital necessary to start the enterprise- demonstrating once again the pivotal role of family networks in accumulating money and resources. If these avenues were not available, individuals sought loans from the bank by taking a mortgage that offered their property as collateral for payment. ${ }^{93}$ Though individuals turned to family and friends first for loans, parochial banks, known as country banks, catered to those who needed different resources for acquiring capital. Businessmen particularly relied on banks to get access to bills of exchange, which allowed them to sell their customers' promises of payment to the bank for cash. ${ }^{94}$ The reliance on such practices and the dependence upon banks for the large

\footnotetext{
${ }^{90}$ Barker, 11; Gillian Cookson, "Family Firms and Business Networks: Textile Engineering in Yorkshire, 17801830s," Business History 39, no. 1 (1997): 1-20, 1.

${ }^{91}$ Sabean, Kinship in Neckarhausen, 36; Sabean and Teuscher, 12-13,17, 24; Lynda Holland, "A Family Affair: A Nineteenth-Century Tale of One Family and Its Business," Family and Community History 14, no. 1 (2011): 24-40, 29; Barker, 123; Morris, Men, Women, and Property in England, 57; Cookson, 1.

${ }^{92}$ Cookson, 1; Alastair Owens, "Inheritance and the Life Cycle in Family Firms in the Early Industrial Revolution," Business History 44, no. 1 (2002): 21-46, 24-5; Pat Hudson, "Financing Firms," in The Rise of the Modern Firm, eds. Geoffrey Jones and Walter A. Friedman (Cheltenham: Edward Elgar Publishing Limited, 2012), 157-81, 157, 159.

${ }^{93}$ Charles More, The Industrial Age: Economy and Society in Britain, 1750-1995 (London: Longman, 1997), 37.

${ }^{94}$ Ibid., 38.
} 
loans necessary to facilitate the running of industrial businesses made the middle-class industrial elite increasingly dependent upon banks. This dependency became problematic because banks held the power within this relationship and could deny aid or demand payment on short notice. For this reason, individuals increasingly had to represent themselves as persons the bank could trust by evidencing their status as respectable business owners with assets to offer as "collateral" or gain influence within the bank's administration by serving as partners or shareholders. ${ }^{95}$ Those who failed to display any of these characteristics and did not have any family or social network ties to fall back on found themselves in a nearly impossible position if the bank demanded payment for their debts. ${ }^{96}$ This study explores the fate of family businesses within the Read network and traces their grave financial difficulties to analyze the experiences of debt and bankruptcy in the nineteenth century.

\section{Conclusion}

This project incorporates the Read family's experiences into the historical narrative by utilizing their lives as a case study to address the role of gender, family networks, kinship, and middle-class morality in family businesses and charitable work. Family correspondence and personal papers play a vital role in this endeavor. These sources show that income, professionalism, religion, middle-class morality, and respectable sociability influenced the family's middle-class identity and daily life. Moreover, they provide insights into a family that does not conform to the traditional narrative of nineteenth-century family history, which predominately focuses on married women. My case study’s focus on widows' and spinsters' roles in the family network represents women whose stories have been neglected in scholarship because their lives did not conform to the stereotype of the bourgeois housewife. Their examples

\footnotetext{
${ }^{95}$ Hudson, 173-4.

${ }^{96}$ Ibid., 177-8.
} 
challenge the notion that women were passive actors within the family network who relied on male breadwinners.

Though the Read sisters faced severe economic dependence on their male relations, they also showed great independence in their charitable outreach, philanthropic activism, and their active participation in the family network's discussions of business and financial matters. The letters demonstrate that though domesticity served as a central ideological framework in women's lives, it did not hinder their engagement in the public sphere; rather, it provided these women with opportunities to harness domestic skills and values to participate in public life that extended beyond their families and traversed the public private divide. Though past works have acknowledged women's important roles in family networks and businesses, the Reads' correspondence offers new insights into how women engaged in their family's efforts to promote stability and cohesion during financial crises and family conflicts.

Furthermore, an examination of the family's personal papers underscores the importance of religion and inward faith in philanthropic work. Many studies of middle-class charitable associations have focused solely on the social power and recognition that the middle classes gained through these endeavors rather than the religious or moral motivations that drove their philanthropy. Often absent an individual voice to address their personal motivations, these studies have generalized that all such actions were simply a means to assert middle-class selfinterest. The Reads' letters, in contrast, present clear evidence on the importance of piety and moral conviction within their religious outreach and charitable engagement. Their examples demonstrate that faith and social responsibility also played an integral part in middle-class charitable work, as well as asserting one's social stature and local influence. 
Divided into five chapters, this project addresses the themes raised here through a series of thematic case studies. Chapter one, The Birth of the "Great Chimneyopolis": Middle-Class Dissenter Manufacturers and the Creation of Urban, Industrial Sheffield, introduces the city and underscores the pivotal role that Nonconformist manufacturers like the Reads played in the city's manufacturing industry and urban development. The second chapter, For Richer or Poorer: Family Networks, Household Strategy, and Gender Roles in Nineteenth-Century Business, 18201837, moves from the city to the family as it explores the Reads' financial crisis to demonstrate the role of men and women within family networks and businesses.

Chapter three, Spinster Domesticity: Middle-Class Single Women's Appropriation of Motherly Roles in Family Networks and Sunday Schools, 1830-1850, analyzes how middle-class spinsters performed their societally sanctioned domestic roles as mothers in their positions within the family network and Sunday Schools. The fourth chapter, Going Tea-Total: The Role of Middle-Class Women and Teetotal Events Within Teetotalism in England, 1830-1850, examines the Read sisters' teetotal leadership to analyze the impact of sociability and domesticity on the temperance movement in an organization led by the Read women. Chapter five, My Brother's Keeper: Conflicts between Personal Ambition and Family Strategy in Nineteenth-Century Family Businesses, evaluates how tensions between personal, professional goals and familial obligations led to strains within the family network. The conclusion observes Wincobank Hall's role in the Reads' story, offers a brief glimpse into the family's legacy in Sheffield, and sums up the main themes and contributions of the project.

The Read family_recognized as influential manufacturers and philanthropists by other leading men and women in Sheffield, Britain, and abroad-- hold an important, but overlooked place in the historical narrative of Victorian Sheffield. In addition to representing a social group 
with rising influence at this time, the family also provides crucial evidence of the enduring influence of family networks and the gendered roles men and women played in supporting the family's interests and philanthropic activism. Ultimately, their example reveals the enduring significance of family networks, religion, and the wide scope of domesticity that sanctioned social outreach in Sheffield during a time of rapid economic growth and transformation. 


\section{Map of Sheffield With Attercliffe's Industrial Area, Around the River Don}

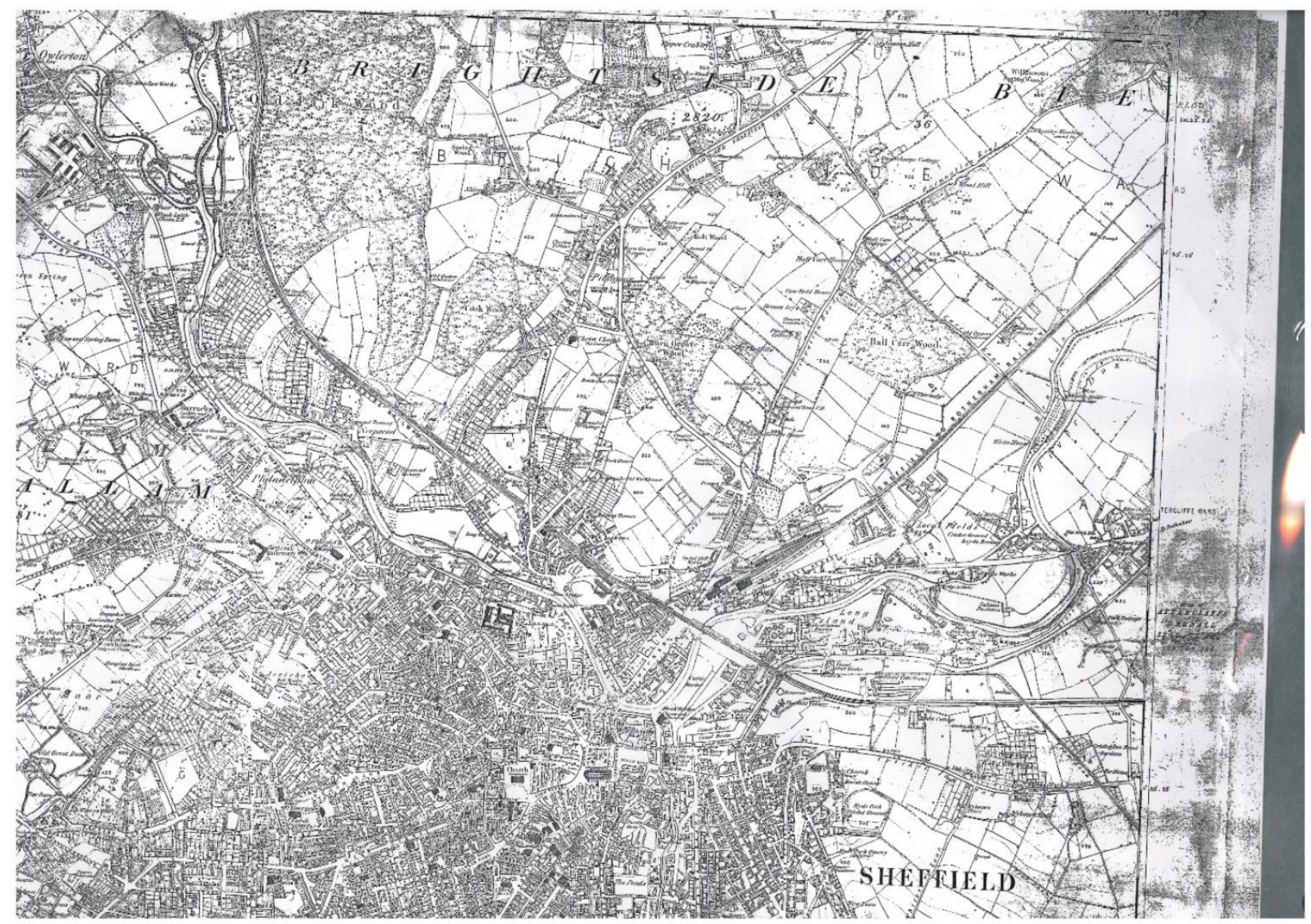

Sheffield City Archives: Ordinance Survey Map Collection 


\section{Chapter 1}

The Birth of the "Great Chimneyopolis": Middle-Class Dissenter Manufacturers and the Creation of Urban, Industrial Sheffield

The day was oppressively dull and heavy, the smoke could not rise, and the aspect of every thing was deplorable. I looked through the not-very-clean windows, upon nothing but dark shabby houses, and thought what a shabby place for the habitation of a Poet! [James Montgomery] came and stood by me and seemed to read my thoughts, and said rather sorrowfully, 'You think this is a rather dingy scene - and so it is,' and then with that sudden change in manner and countenance, I have so frequently observed in him, he added, quite cheerfully, 'But on a clear day, and clear and bright days do sometimes come, even here, though you look so skeptical, I can see between the chimneys your wooden hilly top, and it is wonderful how the slightest peep...of the country, at once carries me away to wander amongst the woods and fields and streams; and this is a privilege we enjoy in Sheffield in a singular degree: on account of the hilly nature of the neighborhood, and of the town itself — on a hill in the midst of hills - there is not a single street from some part of which the country cannot be seen, a blessed source of health to both mind and body. $^{97}$

Mary Anne's lament about the conditions of the city, which she referred to as a "great chimneyopolis" and the gloom surrounding the home of her friend, the renowned poet and philanthropist, James Montgomery, demonstrates the paradoxical nature of life in eighteenthand nineteenth-century Sheffield: a city of smoke and dirt surrounded by a beautiful, almost paradise-like countryside. As this exchange suggested, the atmospheric effects of the city's growing industrial economy made the city an unpleasant place to live. ${ }^{98}$ John Taylor's 1879 Illustrated Guide to Sheffield also described the city as a place of industry amongst remote, stunning scenes of nature. He argued that though they could not "claim [that Sheffield's] manufacturing parts [were] cleaner or less smoky than other similar centres of industry... its extensive suburbs [were] remarkably beautiful, and perhaps no large town [was] situated in so

\footnotetext{
${ }^{97}$ Mary Anne Rawson, “Memorials of James Montgomery,” JMC, SUA.

98 Ibid.
} 
charming and picturesque a district." 99 Using these two accounts as a jumping off point, this chapter addresses the role of middle-class dissenting families like the Reads in the city's rapidly industrializing culture.

Part of the respectable, yet radical middle-class Nonconformist culture in Sheffield, the Reads benefited from the cutlery industry by establishing the smelting company, Read \& Co. in $1760 .{ }^{100}$ Success in this business provided the first two generations with the wealth necessary to establish a mill and company home on Green Lane in Attercliffe-a suburb of the city increasingly becoming the site of industrial works in the eighteenth-century — and three country estates. Grandfather John, the founder of the company, rented Norton House in the village of Norton approximately four miles south of Sheffield; his eldest son, Joseph, the father figure of this case study, bought Wincobank Hall farther into the countryside of Attercliffe in the clean air far away from the parish's industrializing Don Valley; and his younger son, Uncle John, renovated the farmhouse at Derwent Hall into a "gentlemanly seat" worthy of a man of his wealth and taste. ${ }^{101}$

In addition to their engagement in Sheffield's industrial culture, the Reads' Congregationalist convictions also compelled them to support projects that addressed material and spiritual poverty in the city. This chapter explores Sheffield from the perspective of middleclass Nonconformist industrialists to introduce the Reads and their economic, social and religious context in this bustling northern English industrial town. In doing so, it places the

\footnotetext{
${ }^{99}$ John Taylor, The Illustrated Guide to Sheffield And the Surrounding District Comprising Accounts of the Early History and Progress of the Town, Its Public and Religious Bodies, Edifices, and Institutions, Descriptions of Its Manufactures, and of the Suburban Scenery and Places of Interest in the Surrounding District, \&c. (Sheffield: Pawson and Brailsford, 1879), 1.

${ }^{100}$ At the time of its creation, the family company was known as Read \& Lucas, however, for simplicity it is referred to throughout as Read \& Co. as this was the name of the company as of 1824.

${ }^{101}$ Wilson, Two Hundred Precious Metal Years, 62, 69-71. R. E. Wilson attests that Grandfather John acquired wealth and prominence as "one of the most prosperous men in the town." See 35.
} 
Reads within their cultural milieu and provides further context for the following chapters which analyze their engagement in local philanthropy and business from 1837-1860.

\section{Sheffield: Its Geography, Landmarks, and Medieval and Early Modern Legacy}

Located among the rolling and wooded hills at the intersection of Yorkshire and Derbyshire, the city of Sheffield laid claim to a very colorful past that included Romans, Saxons, Normans, Robin Hood, Mary Queen of Scots, and several battles of the English Civil War. Sheffield sits in the southern county of York on the border of Derbyshire and was the capital of the historic shire, Hallamshire - a region encompassing the modern day parishes of Sheffield, Ecclesfield, and Bradfield. ${ }^{102}$ The city's waterways played a central part in its geography and emerging industrial culture. ${ }^{103}$ Sheffield has five streams - the Don, which serves as its main waterway, and its tributaries the Loxley, Rivelin, Porter, and Sheaf- that serve as important geographical boundaries in the city's landscape, and effectively divide the town into its five townships. ${ }^{104}$ The five townships include: Brightside Bierlow north of the River Don, Sheffield on the "south side" of the Don; Ecclesall Bierlow with township of Sheffield to its south which stretches from Moorhead to Cambridge-street and Barker's Pool; Attercliffe-a triangular region above the River Don bordered by Parkhill and the township of Tinsley on each side; and, Nether Hallam and Upper Hallam with the former "southward" of the Don to Crookes and Crosspool bordered on the Rivelin in the Northwest and the latter from Ecclesall and Nether Hallam west to Stanedge with the Rivelin as its northern boundary and the Derbyshire moors as its southern. ${ }^{105}$

\footnotetext{
102 John Holland, The Picture of Sheffield: Or, An Historical and Descriptive View of the Town of Sheffield (Sheffield: Ridge, 1824), 10.

${ }^{103}$ Ibid.

104 Taylor, Illustrated Guide to Sheffield, 2.

105 Ibid., 3.
} 
Sheffield experienced a rapid course of industrialization in the eighteenth and nineteenth century. As local historian John Holland noted, by 1824 what had been "parks and baronial halls" served as "sites of warehouses and manufactories... with busy workmen... surrounded with the bustle of commerce, and the din of the hammer and engine."106 This visceral depiction of the clash between an idyllic, pastoral past and a newly emerging modern, industrial identity underscores Sheffield's unique position as a city on the borders of the country. Though Sheffield had a reputation as the center of cutlery as far back as the fourteenth century, as made most famous by references to Sheffield knives in Geoffrey Chaucer's The Canterbury Tales, the city's industrial, civic, and philanthropic components truly coalesced in the late-eighteenth and earlynineteenth century. Middle-class families, including the Reads and their kinship and philanthropic networks, played a vital role in the city's transformation from isolated town to urban manufacturing city with a crucial role in national industries like cutlery, metalworking, and steel.

Historians have traced Sheffield's production of cutlery as far back as 1341. In the Middle Ages, however, the domination of local affairs by the aristocratic lords who owned the land in Sheffield and its surrounding neighborhoods - the De Lovetots (c. 1160) and later the De Furnivals (c. 1296) - imposed restrictions that severely limited the production of these tools. ${ }^{107}$ Though Taylor's Guide does not argue this point, it seemed clear from Price's work that the aristocratic control over the town had dwindled by the late eighteenth century. The decreasing interest and influence of the landed elite and resulting increase in manufacturing interests amongst the group which would become the middle classes played a pivotal role in the transformation of the town's industries, civil society, and philanthropic life.

\footnotetext{
${ }^{106}$ Holland, The Picture of Sheffield, 10.

107 Taylor, Illustrated Guide to Sheffield, 42, 44, 46-7.
} 


\section{Industry, Dissent, Local Governance, and Radical Politics}

Cutlery production played an integral role in Sheffield's development during the eighteenth and nineteenth centuries due to Sheffield's status as the "foremost centre of cutlery production in Britain." The Cutlers' Company came into being after Parliament passed an act in 1624 allowing the producers of these goods to establish an institution to promote 'good order and government' amongst their tradesmen. ${ }^{108}$ This act established a "corporate" structure made up of a master, two wardens, six searchers, and twenty four assistant searchers which regulated the production of these goods by the other cutlers who did not hold executive positions - known as the "commonality."109 The Cutlers' Company effectively granted its corporate officials a monopoly over the trade by ensuring that only members of the society, known as freemen, could engage in the trade and accepting only a small number of new members each year until Parliament repealed this measure in $1814 .{ }^{110}$ Until 1814 , therefore, the Company acted as a "selfperpetuating oligarchy" within local trade and town affairs. ${ }^{111}$ This unchecked authority led to tensions between free men in the company and the corporate body, especially among the master manufacturers seeking to retain control over the labor within their workshops. ${ }^{112}$ Their influence within the community outlasted their domination of the cutlery trade, as seen in their continued influence within philanthropic projects - especially to aid the working classes during periods of famine and economic instability. ${ }^{113}$ The Cutlery trade, however, only represented one of the

\footnotetext{
108 Taylor, Illustrated Guide to Sheffield, 54.

109 Ibid., 55.

110 Ibid.

111 Price, 1-2.

112 Price, 8; Caroline Reid, "Middle Class Values and Working-Class Culture in Nineteenth-Century Sheffield" (Ph. D. diss, Sheffield, University of Sheffield, 1976), 7.

113 "Distress. To the Master Cutler," Sheffield Iris, Tuesday, January 7, 1817; "Reservoirs on the Moors," Sheffield Iris, Tuesday, January 7, 1817; “The Iris," Sheffield Iris, Tuesday January 7, 1817; “The Iris," Sheffield Iris, Tuesday January 7, 1817.
} 
town's pivotal industries that denoted a rising middle-class manufacturer presence in the town in the eighteenth century.

In the mid-eighteenth century, Sheffield gained an manufacturing interest which would become its "second most important industry[:]" Sheffield Plate. ${ }^{114}$ In 1743, Thomas Boulsover began producing silver and copper fused products known as 'Old Sheffield' plate. ${ }^{115}$ He received a great profit due to its usefulness in producing fashionable items like metal buttons and snuffboxes. Similarly, Joseph Hancock produced larger items that had previously only been made with sterling, such as the lining of saucepans, spoons, forks, tankards, cups, tea urns, and candlesticks-- a lucrative business thanks to middle-class consumer demands for more affordable home goods. In other words, manufactories like Hancock's perpetuated the middle-classes' position by buttressing middle-class fortunes from the production of goods that supported middle-class cultural conventions of domesticity and luxury for prices suitable to this growing section of society.

Most importantly for this project, the predominance of metal goods in Sheffield from these two trades presented the paterfamilias of this case study -- Grandfather John-- with an incredible opportunity. The growth of the cutlery industry and new Sheffield Silver Plate led to a need for silver refining, which salvaged scraps of silver from both industries and transformed them into reworkable materials. Smelting refers to the "separation of metal from dross" or the extraction of metal particles left behind during the production of metal goods. In producing items like gold jewelry manufacturers inevitably lost "fragments" of precious metal while melting the materials to produce the necessary alloy or conducting other parts of the manufacturing

\footnotetext{
${ }^{114}$ Price, 2; Wilson, Two Hundred Precious Metal Years, xvii.

115 Wilson, Two Hundred Precious Metal Years, xvii.
} 
process. ${ }^{116}$ Though only small remainders are left behind in each of these processes, when collected en masse the leftovers have substantial value. ${ }^{117}$ During the production of these goods, precious metal particles became intermixed with a larger percentage of non-valuable materials and the remaining precious metals could only be retained by "sweep[ing] up and collect[ing] the dust and rubbish" created during these processes. ${ }^{118}$ For this reason, the leftover product that smelters process is called sweep. Only through smelting and refining can gold, silver, copper, and lead be extracted from the other "rubbish" materials. ${ }^{119}$

Though Taylor's guide referred to smelting as a "very old industry" in the city, the silver refining business only started in the mid-eighteenth century. ${ }^{120}$ The Reads played a pivotal role in establishing this industry—whose importance within the town led Taylor to mistakenly imagine it had been carried out in Sheffield for a longer time than it truly had. ${ }^{121}$ In 1760 , Grandfather John moved to Sheffield to start a smelting company, Read \& Co., with his maternal uncle and fellow refiner, Samuel Lucas in order to take advantage of its "small but rapidly growing silver trade." 122 Most importantly for Grandfather John, the town did not have a smelter in the neighborhood, which meant that they essentially monopolized the increasing amount of silver particles produced. ${ }^{123}$ Even though Grandfather John and his uncle had limited resources and had to initially focus on refining silver copper scrap, the business became so profitable that Grandfather John soon had the capital to move to the industrializing region of Attercliffe. There,

\footnotetext{
${ }^{116}$ Wilson, Two Hundred Precious Metal Years, xii.

117 Ibid.

${ }^{118}$ Ibid., xii-xiii.

${ }^{119}$ R. E. Wilson includes the process of refining —or the "separation and purification of metals" in his definition of smelting within this study of the family company and therefore this study does as well. Wilson, Two Hundred

Precious Metal Years, xiii.

${ }^{120}$ Taylor, Illustrated Guide to Sheffield, 294.

${ }^{121}$ Wilson, Two Hundred Precious Metal Years, xi.

122 Ibid., 3, 8.

${ }^{123}$ Ibid., 8.
} 
he built the larger premises and refining plant necessary to expand the types of sweep the company processed. ${ }^{124}$ This success marked the origin of a family business that would remain in the hands of its descendants for two hundred years. ${ }^{125}$ Like many dissenter manufacturers in eighteenth-century Sheffield, Grandfather John used his wealth to engage in the city's public life and participated in a growing middle-class culture.

The middle classes played an integral role in local governance due to decreased aristocratic interest in the city in the eighteenth and nineteenth centuries. Despite the fact that aristocratic elites like Earl Fitzwilliam, the Duke of Devonshire, the Duke of Norfolk, and the Stuart-Wortleys of Wortley Hall owned land in and around the city and profited from the town's growth, the landed elite did not show any interest in town affairs or intervene in local administration. Aristocratic ambivalence meant that the city's middle classes dominated the three central "bodies" of local "governance:" the Church Burgesses, the Town Trustees, and the Cutler's Company. ${ }^{126}$ The Church Burgesses oversaw Anglican religious and educational endeavors in Sheffield, the Town Trustees took initiative for public matters like roads, bridges, water supplies, etc., and the Cutler's Company managed the town's industry. In addition to local power structures, religious dissent and middle-class urban leadership generated a reformoriented, radical environment in Sheffield.

The prevalence of Nonconformity in Sheffield shaped the political, economic, and social makeup of the town. By the nineteenth century, Sheffield gained a reputation as a hub of radical ideas-- the presence of a liberal, Nonconformist middle class contributed significantly to the

\footnotetext{
${ }^{124}$ Wilson, Two Hundred Precious Metal Years, 8, 9-10.

${ }^{125}$ Ibid., xi.

126 Price, 3.
} 
city's character. This radical, reforming presence was particularly influential within Sheffield due to the imbalance between its Nonconformist chapels and Anglican churches. ${ }^{127}$

Local histories of Sheffield emphasize the longstanding history of the city's

Nonconformist majority. During the English Civil War many of the city's inhabitants supported Parliament and following the 1662 Act of Uniformity, the city's clergy refused to conform to the liturgy of the established Church. Indeed, during the Restoration, the non-conforming clergy faced the monarchy's retribution when the government imprisoned their "puritan vicar" James Fischer. Fischer's followers refused to attend the state parish church and eventually founded Unitarian and Congregationalist chapels. Given the diversity of Nonconformity in SheffieldMethodists, Congregationalists, Baptists, Unitarians, Presbyterians, and Friends-- the city was well supplied with Dissenter preachers. ${ }^{128}$ Conversely, during the eighteenth century there were only three Anglican churches, including a parish church that needed serious repairs. ${ }^{129}$

Congregationalists, or "Independents," had a prominent and visible role in the community, though they were outnumbered by the Methodists. Chapel building started rapidly in the eighteenth-century thanks to the Act of Toleration of 1689, which lifted banns of dissenter worship in public and by 1870 the city held seventeen Congregationalist places of worship. ${ }^{130}$ This trend started with the construction of four chapels from the early to late eighteenth century: Nether Chapel (1715), Queen Street Chapel (1783), Garden Street Chapel (1780), and Howard Street Chapel (1790). The oldest of these churches, the Nether Chapel, still stands on Norfolk

\footnotetext{
${ }^{127}$ Price, ix, 4. David Price's study of eighteenth- and nineteenth-century Sheffield argued that one of the town's radicalizing forces was the "effective balance between its Church establishments and religious dissent." Though Price referred to this phenomenon as balance, I argue that it may be more accurately described as a religious imbalance because of the growing public presence of Nonconformity in Sheffield compared to its Anglican congregations.

${ }^{128}$ Taylor, The Illustrated Guide to Sheffield, 96-100; Price, 4.

${ }^{129}$ Price, 4, 6.

${ }^{130}$ Holland, The Picture of Sheffield, 113; Taylor, The Illustrated Guide to Sheffield, 99-100; Twells, The Civilising Mission and the English Middle Class, 28.
} 
Street. ${ }^{131}$ Grandfather John played a pivotal role in the investment and supervision of the Queen Street Chapel, which became the "hub of Sheffield evangelicalism."132 According to R. E. Wilson, Grandfather John served as a principal subscriber to the chapel's funds and took personal responsibility for acquiring its first minister, Mr. Brewer. ${ }^{133}$

In addition to the rapidly growing number of chapels, the successful abolition of the church rates in 1819-19 —making it "one of the first towns to end payment of church rates"-attests to the Sheffield dissenters' influential presence in town affairs. ${ }^{134}$ Government subsidization of the Anglican church compelled Nonconformists to financially support the state church by paying these church rates. Unlike Anglican churches, Dissenter chapels did not receive any funding from Parliament and relied entirely on the voluntary contributions of its congregation. Dissenters therefore resented the enforcement of church rates and largely advocated for the separation of church and state via the disestablishment of the Church of England. ${ }^{135}$ Since the Compulsory Church Rate Abolition Act did not take place until 1868, the local abolition of this burdensome fee in Yorkshire demonstrated the local influence of Nonconformists. The city's pioneering reform illuminates a transformation amongst Dissenters in Sheffield in the eighteenth and nineteenth centuries from a marginalized group of angry radicals who defied religious and cultural norms to an active, essential element of the city's political and philanthropic culture.

\footnotetext{
131 Taylor, The Illustrated Guide to Sheffield, 96-100.

${ }^{132}$ Wilson, Two Hundred Precious Metal Years, 36; Twells, The Civilising Mission and the English Middle Class, 61.

${ }^{133}$ Wilson, Two Hundred Precious Metal Years 36.

134 Price, 32.

${ }^{135}$ Isaac Kramnick, "Religion and Radicalism: The Political Theory of Dissent," in Republicanism and Bourgeois Radicalism (Cornell University Press, 1990), 53-4.
} 
In addition to religious life, dissenter culture also heavily influenced local governance. The Test and Incorporation Acts restricted even educated Nonconformists from holding political offices or voting in elections. ${ }^{136}$ For example, according to an early biographical account of the Reads' lives, the father of this case study, Joseph Read, was so prominent within the city's affairs that some suggested he run for Justice of the Peace. He was not eligible for office, however, because he refused to take Anglican communion. ${ }^{137}$ Nonconformists' exclusion from national politics led these men to utilize opportunities for civic activism in local affairs through societies like the Cutlers Company, Town Trustees, Overseers of the Poor, and the General Infirmary and Dispensary as proof of their capacity for political participation and dedication to the town. ${ }^{138}$ Sheffield's example was not unique as various scholars' studies of other cities in the eighteenth and nineteenth centuries demonstrate similar behavior and incentives amongst the middle classes, especially Nonconformists. ${ }^{139}$ Their engagement in local administration enabled them to shape the town and also fueled Sheffield's radical political culture.

In addition to making middle-class Nonconformists adamant about using whatever entities they could to engage in town government and philanthropy, their exclusion from political office attracted them to radical political ideas that stressed the need for drastic changes in national political culture. ${ }^{140}$ According to Isaac Kramnick's study of nineteenth-century middleclass dissenters, their experiences of seclusion and persecution by the Anglican majority shaped their self-image as outliers, which in turn fueled their acceptance of radical ideas that celebrated

\footnotetext{
136 Price, 4.

137 Taylor, "Life of Mary Anne Rawson," 1.

${ }_{138}$ Price, 4; Twells, The Civilising Mission and the English Middle Class, 63.

${ }^{139}$ See Porter; Wilson, Sense of the People; R. Tudur Jones, Congregationalism in England, 1662-1962 (London: London Independent Press Ltd., 1962), 187.

${ }^{140}$ Price, 5.
} 
their otherness by reforming the status quo. ${ }^{141}$ In Sheffield, this sense of isolation and the injustice of their own exclusion from politics fostered an openness to liberal ideas and sympathetic support for the lower classes' radical political demands. By the late eighteenthcentury, the reform-oriented middle classes and the lower classes shared "common interest[s] in reform [and sympathies with] new libertarian ideas [from] Paris [and] Thomas Paine['s writings] if only "superficially." Though the middle classes claimed that they promoted political change, they were often supporting lower property requirements for voting, whereas the working classes championed universal manhood suffrage. ${ }^{142}$

One of these prominent radical, middle-class dissenters was a member of the Reads' kinship network-Samuel Shore. Shore served as a member of the Town Trust, a High Sheriff in the County of Derby in 1761, and a pivotal member of the Yorkshire Association-- a society that promoted parliamentary reform. ${ }^{143}$ Despite his sympathy for radical working-class demands for political reform, he rejected their demands for voting rights. ${ }^{144}$ Shore was not a unique case- the middle classes were largely receptive to radical political ideas like the challenges to monarchical and aristocratic power in the first phase of the French Revolution; as attested by the popularity and prominence of pro-revolutionary newspapers like the Sheffield Register and the Sheffield Iris - the latter of which was edited by the Reads' friend, James Montgomery, a prominent poet, reformer, and (erstwhile) supporter of early revolutionary politics. ${ }^{145}$ The political cohesion of these two groups' political ideas - even if more in theory than in practice - led to cooperation amongst the middle and working classes.

\footnotetext{
${ }^{141}$ Kramnick, 46-49. Lucy Aikin, a member of the Priestley circle, recorded her recollections of a childhood where the other children not only rejected her, but called her names and physically assaulted her. See "Religion and Radicalism," 47.

142 Price, 7,9, 28.

143 Ibid., 5.

144 Ibid., xi, 16.

145 Ibid., 10.
} 
According to Pollard's study, Sheffield did not experience class tensions because manufacturers, small masters, and artisans generally held the same radical, liberal political views. Moreover, the desire and ability for artisans to achieve social mobility by becoming small masters and the retainment of artisans' "possession of their tools and other means of production" combined with the narrow [social] gap [between the] master and workman" in Sheffield fostered class cohesion. ${ }^{146}$ The lack of social distinction in the late eighteenth-century, shared political principles, and sustainment of control over their occupational implements led the working classes to reject socialism as a political alternative and to support similar liberal, radical politics as the middle classes. ${ }^{147}$ Traces of this cooperation remained as late as the 1820 s and 30 s when the working classes and middle classes supported the same causes, such as the crusades for Catholic emancipation, anti-slavery, and aid for climbing boys (chimney sweeps) and agitation for political reform leading up to the Reform Act (1832). ${ }^{148}$ This fluid gap between the middle classes and the working classes also played a large role in the development of a middle-class identity from the late eighteenth to nineteenth centuries. The path of industrialization had a large impact on another facet of the city's civic culture: civil society and philanthropy.

\section{Industrialization, Civil Society, and Philanthropy in Nineteenth-Century Sheffield}

The rise in industry had an important impact on life in the town, especially for the working classes. In the eighteenth century, artisans lived with their families and apprentices in cottages situated around the River Don, which powered their grinding wheels. ${ }^{149}$ After the

\footnotetext{
${ }^{146}$ Sydney Pollard, A History of Labour in Sheffield (Liverpool: Liverpool University Press, 1959), 41.

${ }^{147}$ Ibid.

148 Ibid.

${ }^{149}$ Massiliano Mollona, "An Ethnography of Industrial Work and Politics," in Made in Sheffield, (Berghahn Books, 2009), 63. In larger "hamlets" artisans, known as "little mesters' or "artisan capitalists" established their own works which included crucible furnaces, workshops that "finished... scythes and blades," and separate homes for the workers and the 'little mester.'
} 
invention of the steam engine and the growth of industry in the mid-nineteenth century, artisans moved from homes on the river to back-to-back houses in Endcliffe and "tightly packed dwelling $[\mathrm{s}] \ldots$ in Ecclesall and Nether Hallam.." ${ }^{\prime 50}$ The problematic nature of this change in working-class living space is perhaps best seen in the back-to-back houses at Endcliffe; where an average of twenty families shared courtyards that housed pigs, domestic animals, tool workshops, and privies, around 5.2 people slept in one bedroom, and smells and debris permeated homes through broken windows, missing doors, and holes in the roof. ${ }^{151}$ The inferior condition of living in towns with dirt and smoke as well as the concerns raised by poverty, irreligion, and drunkenness provided middle-class manufacturers with social crusades that legitimized their interest and involvement in the lower classes' affairs. These projects, though designed to help the working classes, often broadened the gap between the two segments by endorsing or enforcing codes of conduct and principles identified with this increasingly cohesive section of society.

The rise of civil society via associational life in late eighteenth- and nineteenth-century Sheffield can be directly linked to the creation of a manufacturing and commercial identity in the town through engagement in the public sphere. Although inspired by their religious vocation, the Read family's engagement in philanthropic activities represented an important component of their reform oriented middle-class identity. Studies on the English and continental middle classes since the 1980s have demonstrated that middle-class engagement in philanthropy demonstrated how men and women employed charitable work to address social problems and secure middleclass authority. ${ }^{152}$ On one hand, throughout the eighteenth and especially the nineteenth century,

\footnotetext{
${ }^{150}$ Pollard, 5; Mollona, 63-4.

${ }^{151}$ Mollona, 64.

${ }^{152}$ See Davidoff and Hall, Family Fortunes; Twells, The Civilising Mission and the English Middle Class; Wilson, Sense of the People; Porter; Midgley, Women Against Slavery.
} 
the middle class remained consumed with shaping "civic culture." In Sheffield with its cutlery, silver plate, and crucible steel industries, a "middle-class manufacturer interest" emerged over time to initiate an infirmary, various hospitals, the Boys' Charity School, Girls' Charity School, Birley's Charity, Barlow's Charity, Kirkby's Charity, Parkins' Charity, Humane Society, Aged Female Society, Church Missionary Association, Society for Promoting Christian Knowledge, Church Tract Society, Literary and Philosophical Society, various Missionary Societies, Mechanics' Library, and Mechanics' Institute. ${ }^{153}$ Moreover, central institutions within the town's public culture like the Tontine Inn, which served as a meeting place and center for travel thanks to its accommodations and the coach services it offered, relied on the financial investments of men like Grandfather John. ${ }^{154}$ Middle-class societies and organizations participated in the public sphere not only through their meetings and projects, but by advertising their work, literature, events, and membership lists in another crucial aspect of civil society-the press. ${ }^{155}$ The press in Sheffield reflected this rising civil culture through the battles between conservative papers like the Sheffield Advertiser, the Sheffield Courant, the Sheffield Mercury and radical, liberal ones like the Sheffield Register, the Sheffield Iris, and the Sheffield Independent. ${ }^{156}$

${ }^{153}$ Holland, The Picture of Sheffield, 201-30; Twells, The Civilising Mission and the English Middle Class, 53-60.

${ }^{154}$ Wilson, Two Hundred Precious Metal Years, 35; Taylor, The Illustrated Guide to Sheffield, 116-7.

155 "Society for Bettering the Condition of the Poor in Sheffield," Sheffield Iris, Tuesday, September 4, 1821; "Society for Bettering the Condition of the Poor," Sheffield Iris, Tuesday, March 27, 1821; "Society for Bettering the Condition of the Poor in Sheffield," Sheffield Iris, Tuesday, August 9, 1825; "Subscriptions for the Relief of the Poor," Sheffield Iris, Tuesday, January 27, 1817; "Subscriptions for the Relief of the Poor," Sheffield Iris, Tuesday, February 4, 1817; "At a Meeting of the Overseers of the Poor," Sheffield Iris, Tuesday, March 4, 1817; "To the Rate-Payers of Ecclesall- Bierlow," Sheffield Iris, Tuesday, October 23, 1821; "At a Meeting of the Overseers of the Poor," Sheffield Iris, Tuesday, March 4, 1817; "To the Public," Sheffield Iris, Tuesday February 25, 1817; "Bible Society," Sheffield Iris, Tuesday August 26, 1823; "Sheffield Auxiliary Bible Society," Sheffield Iris, Tuesday, September 30, 1823; "Tract Society," Sheffield Iris, Tuesday, October 23, 1821; "Religious Tract Society," Sheffield Iris, Tuesday, September 30, 1823; "Church Missions," Sheffield Iris, Tuesday, June 21, 1825; "Wesleyan Methodist Missions," Sheffield Iris, Tuesday, March 22, 1825; "Wesleyan Methodist Missions," Sheffield Iris, Tuesday, March 29, 1825; "Missions to Africa and the East," Sheffield Iris, Tuesday, June 10, 1823; "Church Missions," Sheffield Iris, Tuesday, June 21, 1825; "Moravian Missions," Sheffield Iris, Tuesday, September 16, 1823; Reid, "Middle-Class Values and Working-Class Culture in Nineteenth-Century Sheffield," 169.

${ }^{156}$ Price, 17, 19-20, 32. 
Organizational meetings, fundraising events, and advertisements in papers and pamphlets represented key components of middle-class activities that sought to reform and improve their city. For middle-class men, their participation in such "voluntary bodies soon mapped onto other sites of urban power" as well as "social power" endorsing their status as moral authorities and advocates for progress and reform. ${ }^{157}$ As historian Alison Twells has demonstrated, benevolence emerged as a central theme within middle-class masculine ideals as it offered men opportunities to engage in matters that demonstrated their status as "reformed, Christian middle-class" men by using their "sensitivity, morality, and guidance to [help] others." 158

In addition to bolstering their authority within the social hierarchy, philanthropic work provided men with public occasions to perform their masculine roles as protectors of dependents. It is therefore not surprising that the most well-known group of middle-class men in Sheffield at this time were renowned for their dedication to philanthropic works. Twells' study of "the four friends" - George Bennet, Rowland Hodgson, James Montgomery, and Samuel Robertsdemonstrated that their common interest in improving life in Sheffield led to the creation of numerous charitable societies. Their services in the Society for Bettering the Condition of the Poor (1804), Sheffield Auxiliary Bible Society (1810), Anti-Slavery Society (1824), and the Temperance Society (1831), as well as various Sunday and Lancastrian Schools (1809) evidences their dedication to poor relief and religious outreach. ${ }^{159}$ The father figure of this case study, Joseph Read, supported these causes and formed a friendship with half of this influential group—James Montgomery and George Bennet frequently dined at Wincobank Hall. ${ }^{160}$

\footnotetext{
157 Twells, The Civilising Mission and the English Middle Class, 5, 63.

${ }^{158}$ Ibid., 53.

${ }^{159}$ Ibid., 54-6.

${ }^{160}$ Mary Anne Rawson, “Memorials of James Montgomery,” JMC, SUA.
} 
Though men may have been the most prominent figures in civil society, charitable work was not solely a male pursuit-- middle-class women also engaged in voluntary societies and their gendered roles as caretakers played a pivotal role within their philanthropic activism. The Sheffield branch of the Society for Bettering the Condition of the Poor (hereafter referenced as SBCP) provides a pivotal example of middle-class men and women's engagement in poor relief. William Wilberforce, Shute Barrington, and Thomas Barnard established the first SBCP in London in 1796, which became a forerunner of Victorian reform. The Sheffield auxiliary branch was established in 1804 to "alleviate distress [by reforming] bad habits [that] exacerbate[d] poverty."161 The Read women joined other middle-class families who supported poor relief as members of the SBCP: Mary Anne Rawson, her mother, and her sisters were active supporters of the Society by $1814 .{ }^{162}$ In 1824 local historian John Holland described the well-known Society’s goals: "promot[ing] the welfare and comfort of the poor, by ... encouraging... industry, economy and order."163 Combining poor relief and religious outreach, this organization focused on offering material aid and teaching middle-class values.

Women played an important role in the SCBP as it was one of many charitable endeavors that used home visits to aid needy families. According to Holland, home visits involved offering assistance to sick or poor families, married women during their confinement, and inhabitants of work houses or debtors prisons, and ensuring that children received a proper moral education. ${ }^{164}$ As moral and domestic authorities, middle-class women helped the lower classes by teaching them the skills and knowledge necessary to construct a safe, healthy and respectable home. ${ }^{165}$

\footnotetext{
161 Twells, The Civilising Mission and the English Middle Class, 57.

162 Ibid., 9.

${ }^{163}$ Holland, The Picture of Sheffield, 219.

164 Ibid., 120-121

165 Twells, "Missionary Domesticity, Global Reform, and 'Woman’s Sphere' in Nineteenth-Century England,” 2 , 268, 279; Twells, The Civilising Mission and the English Middle Class, 9.
} 
For example, the SBCP encouraged the cultivation of middle-class patterns of domesticity by loaning or selling domestic materials like "bedding and clothing" at a reduced price. These women's expertise was vital because nineteenth-century charitable associations often championed middle-class manners and values as a means to better the lives of the poor. Women's domestic roles prepared them to act as instructors on proper domestic, familial, and moral matters during their interactions with the working classes in outreach like home visits. ${ }^{166}$

Home visits provided opportunities for middle-class women to personally survey working-class living spaces and determine the sincerity of the families' needs and their willingness to reform themselves. Twells noted that the philanthropist and missionary, Hannah Kilham, envisioned home visits as a way to understand the working classes' lives 'by seeing them in their own houses, and hearing [their] suffering and privations'; whether their intentions were pure or not, middle-class women ultimately decided who would be supported and defined who were good and bad based on their "judgement and feelings" as moral authorities. ${ }^{167}$

Only working-class families who accepted middle-class reformist definitions of proper behavior and practices, therefore, received aid. The supervision of the working classes, including home visits and related practices, enhanced middle-class authority by placing middle-class women as judges of a working-class individual's deservedness or worthiness for assistance. Individuals had to prove themselves willing to commit to respectable, pious middle-class standards to be deemed eligible. ${ }^{168}$ This caveat demonstrates that though the intention may have

\footnotetext{
166 Twells, The Civilising Mission and the English Middle Class, 70.

167 Ibid., 74.

168 The concept of "deserving" and "undeserving" poor essentially categorized the working classes into categories that assumed the legitimacy of the individual receiving aid based on their personification of middle-class values like chastity, hard work, economy, and decency. Those who did not fit into these qualifications were social outcasts not worthy of aid. See Rachel F. Fuchs, Gender and Poverty in Nineteenth-Century Europe (Cambridge: Cambridge University Press, 2005), 38, 41, 198; Carolyn D. Williams, Angela Escott, and Louise Duckling, Woman to Woman: Female Negotiating During the Long Eighteenth Century, (Newark: University of Delaware Press, 2010$), 128$. Though Twells' uses an example from Thrift Clubs to demonstrate this point, this practice is an overreaching theme
} 
been to help the lower classes, the SBCP's work also reinforced their own middle-class notions of correct behavior and practices, which in turn helped to solidify the emerging middle-class culture surrounding these values.

Like the SBCP, Bible Societies also utilized home visits to condone proper domestic piety. These Societies promoted familial, spiritual, and domestic harmony by encouraging families to read the Bible as a manual on domestic happiness and morality. ${ }^{169}$ The British and Foreign Bible Society (hereafter BFBS) was perhaps the most famous example of a Bible society with national and global outreach that sought to help both the British lower classes and the natives in the empire by spreading Christianity and middle-class values. Like the SBCP, the Bible Society in Sheffield was a local auxiliary branch of a larger national society established in London. Dr. Charles Steinkopff, pastor of St. Mary's German Lutheran Church, established the BFBS, which distributed Bibles and pamphlets. He was inspired by the sermons of two itinerant preachers-- Reverend John Owen and Joseph Hughes—-who advocated Christians' obligations to spread the faith. ${ }^{170}$ The Reads supported the Sheffield auxiliary society of the BFBS in Sheffield and were members from the time of its origin in $1812 .{ }^{171}$ The BFBS and its auxiliary societies relied on middle-class women's engagement as it was predominantly women who conducted home visits, delivered Bibles, and collected money.

These associations promoted religious education and faith by subsidizing the lower classes' purchase of Bibles at a discounted rate. Though it may seem strange that the Society charged individuals for Bibles, Bible Societies strategically used this method to teach the lower

amongst all charitable societies that utilized home visits. See Twells, The Civilising Mission and the English Middle Class, 73.

169 Ibid., 76.

${ }^{170}$ Ibid.

${ }^{171}$ Ibid., 87. 
classes valuable lessons about economy. Individuals paid one guinea to join the society and purchased their Bibles either in one lump sum or in installments. ${ }^{172}$ This tactic, which represented the Society's civilizing mission, rewarded thriftiness and showed them the necessity of "making choices, forward planning, careful thought and frugality." "173 Bible Societies used testimonies from members who had already paid for their own Bibles and now wanted to save up enough money to buy them for someone else, took pride in their ability to donate to the Society, or read their Bibles to sick family members as proof of this method's success. ${ }^{174}$ This facet proves that Bible Societies not only sought to improve the spiritual lives of its members, but to also inculcate them with middle-class values.

Middle-class women's roles in collecting dues and payments for Bible Societies caused a backlash within nineteenth-century society. Whereas their work for the SBCP involved conducting domestic outreach and benevolent businesses, the latter muddled the boundaries of acceptable feminine behavior. Some critics questioned if it was morally right to coerce the lower classes to give money to help others when doing so diminished their abilities to support their own families. Bible Societies responded to this argument by asserting that only through learning to economize and to use one's wealth to aid the less fortunate could the lower classes better themselves. Other naysayers argued that women were taking too active of a role by aggressively canvassing working-class neighborhoods and accepting donations and payments-- actions that seemed to defy the feminine virtues of "modesty" and "diffidence." 175 Yet again members of these societies, particularly its female agents, contested this censure and asserted that women had

\footnotetext{
${ }^{172}$ Reid, "Middle-Class Values and Working-Class Culture in Nineteenth-Century Sheffield," 167. This was still presented as a great initiative because the Bibles were worth "five times" the price of "their subscriptions."

${ }^{173}$ Twells, The Civilising Mission and the English Middle Class, 79.

${ }^{174}$ Ibid., 77.

${ }^{175}$ Ibid., 80.
} 
an obligation to promote "truth and morals" within their community by participating in the “religious public.” Twells' work situated women's engagement in Bible Societies within the larger model of civil society by framing these women's insistence on participation in the "Christian public [as an] essential [aspect of] civilised society." 176 Though Norma Taylor's and Twells' studies did not discuss details of the family's involvement in Sheffield's Bible Society, they noted that, as members of the Missionary Society and the SBCP, the Read sisters carried out similar activities to those described above; the girls conducted home visits, handed out religious tracts, read the Bible aloud, collected for missionary expeditions, and beseeched families to enroll their children in the family's Sunday School. ${ }^{177}$ These roles fit into Twells' argument about engaging in the "Christian public" as the Reads' activism in these societies promoted both Christian and middle-class moral, civilizing values.

Middle-class men and women also engaged in the public sphere through separate male and female auxiliary societies like anti-slavery societies. Recent scholarship on the anti-slavery movement, such as David Turley's The Culture of English Anti-Slavery, links middle-class male dissenters' criticisms of the current political system with their activism to overthrow the tyrannical, immoral practice of slavery. ${ }^{178}$ Other scholars have analyzed the networks established by British abolitionists, revealing the important role that kinship networks played in anti-slavery activism. The Reads' experiences conform to the historiography on British abolitionism. Joseph Read and his philanthropic and kinship networks engaged in the anti-slavery movement in Sheffield. He was active with his friends James Montgomery and William Ford

\footnotetext{
176 Twells, The Civilising Mission and the English Middle Class, 80-1.

177 Taylor, "Life of Mary Anne Rawson," 4; Twells, The Civilising Mission and the English Middle Class, 87-88.

${ }^{178}$ David Turley, The Culture of English Anti-Slavery, 1780-1860, (London: Routledge, 1991). Though Turley focuses on rational dissenters, I argue that Joseph Read and James Montgomery's political stance on conservative power structures places them within this framework as well.
} 
Rawson - the latter of whom later became his eldest daughter Mary Anne's father-in-law.

Joseph, Montgomery, and Rawson played formative roles in the creation of Sheffield's auxiliary branch of the London Anti-Slavery Association. ${ }^{179}$ These three men shared dissenter backgrounds as Congregationalists, Moravians, and Baptists, suggesting that their anti-slavery work served as an extension of their protests against political injustice. The Sheffield AntiSlavery society also rejected the apprentice system as a poor solution to the abolition of slavery. On July 22, 1833, Joseph acted as chair of the Anti-Slavery Society meeting and voiced the Society's opposition to the apprenticeship of slaves, which they lambasted as "only a state of modified slavery under another name [that would lead to] insurrection and bloodshed in the Colonies." 180 Joseph, his philanthropic network, and his kinship ties were also supportive of the petition for the abolition of slavery. Joseph, Montgomery, Rawson, and Joseph's relative, John Shore Jr., drafted and signed a petition to Parliament advocating the "gradual abolition of slavery." 181 Joseph and his cohort's anti-slavery activism suggests that the Sheffield anti-slavery movement conforms to other anti-slavery activism as seen through the role of Nonconformity and social networks of family and friends.

Women began to form their own auxiliary anti-slavery societies in the 1820 s. The first of these was the Female Society for Birmingham founded in 1825 by Lucy Townsend. Women's involvement in the British anti-slavery movement has only been acknowledged in scholarship since the 1990s. ${ }^{182}$ Prior to these studies, most research focused on the role of important men

\footnotetext{
179 “Abolition of Slavery," August 14, 1824, Sheffield Independent, British Newspaper Archive Database (Hereafter BNA).

180 “Anti-Slavery Society,” July 22, 1833, Sheffield Independent, BNA.

181 "Petition To Abolish Slavery," April 26, 1823, Sheffield Independent, BNA.

182 For example, Midgley, Women Against Slavery; Charlotte Sussman, Consuming Anxieties: Consumer Protest, Gender, and British Slavery, 1713-1833 (Stanford: Stanford University Press, 2000); Kathryn Kish Sklar and James Brewer Stewart, Women's Rights and Transatlantic Antislavery in the Era of Emancipation (New Haven: Yale University Press, 2007); E. J. Clapp and J .R. Jeffrey, Women, Dissent, and Anti-Slavery in Britain and America, 1790-1865 (Oxford: Oxford University Press, 2011).
} 
who were the leaders of the anti-slavery movement like Thomas Clarkson and William

Wilberforce. Recent works like Clare Midgley's on imperial activists, however, have acknowledged women's contributions to important milestones throughout the campaign such as the passing of important pieces of legislation like the Slave Trade Act in 1807 and the Slavery Abolition Act of $1833 .^{183}$

Understood as an imperial and political question, many eighteenth- and nineteenthcentury contemporaries deemed abolitionism an inappropriate subject for women. However, recent scholarship demonstrates that women were able to overcome these censures by playing upon their domestic roles and their inherent sensibility as the moral guardians of the family. They emphasized the terrible injustices that slave women endured, such as rape, the sale of slave children, and the abuse and whipping of all slaves. ${ }^{184}$ Middle-class women's involvement in the abolition movement illustrated that women could blur the boundaries of the separation of spheres model by playing upon their role as moral and domestic guardians.

Like her father, friend, and future father-in-law, Mary Anne Rawson was deeply involved in the city's anti-slavery movement through the Sheffield Female Anti-Slavery Society and the Sheffield Ladies' Anti-Slavery Society, which were female auxiliary societies to the men's antislavery society. Mary Anne and her mother, Elizabeth Read, served as committee members for the Sheffield Female Anti-Slavery Society on its establishment in $1825 .{ }^{185}$ Women's anti-slavery work included crucial outreach efforts such as participating in boycotts, canvassing with

\footnotetext{
${ }^{183}$ Through this focus on sensibility, local women's societies aided the cause through distributing literature, collecting signatures for petitions, and raising awareness of the evils of slavery. Midgley, Women against Slavery. ${ }^{184}$ Sussman; Brycchan Carey, British Abolitionism and the Rhetoric of Sensibility: Writing, Sentiment, and Slavery, 1760-1807 (Basingstoke: Palgrave Macmillan, 2005); Midgley, Feminism and Empire.

185 Twells, The Civilising Mission and the English Middle Class, 99.
} 
petitions, and making and selling home goods as fundraising efforts. ${ }^{186}$ The reports of these auxiliary societies offer further evidence of women's dedication to educating the public about the evils of slavery and their militance in effecting the abolition of slavery in the empire and abroad. ${ }^{187}$

In addition to protecting slave families, the middle classes also sought to aid lower class families by addressing their supposed irreligious, immoral lifestyles through temperance societies. In some ways, Sheffield's temperance movement both conformed and deviated from the traditional temperance narrative in Great Britain. Like many larger northern cities, the temperance movement in Sheffield began as a response to contemporary concerns about the high rate of drunkenness amongst the working classes. ${ }^{188}$ As scholars like Twells have shown, it also served as both a reaction and potential solution to lower-class radical political traditions like Chartism. ${ }^{189}$ In September of 1831, temperance sympathizers established the Sheffield Temperance Society, which sought to address alcoholism by decreasing the consumption of spirits like gin. ${ }^{190}$ When this agenda failed to adequately reduce drunkenness, some within the movement asserted that all forms of intoxicants—including beer and wine—-were dangerous and should be entirely rejected. This idea led to the development of a branch of temperance known as

\footnotetext{
${ }^{186}$ Midgley, Women Against Slavery; Midgley, Feminism and Empire; Alison Twells, 'We Ought to Obey God Rather than Man'; Alison Twells, The Civilising Mission and the English Middle Class; Sussman.

${ }^{187}$ Sheffield Female Anti-Slavery Society, Report of the Sheffield Female Anti-Slavery Society, established midsummer 1825, Wilson Anti-Slavery Collection (hereafter WASC), University of Manchester, the John Rylands University Library; Sheffield Female Anti-Slavery Society, Report of the Sheffield Female Anti-Slavery Society 1827, WASC; Sheffield Female Anti-Slavery Society, Report of the Sheffield Female Anti-Slavery Society, delivered on Tuesday, Oct. 9, 1832, WASC; Sheffield Ladies Anti-Slavery Society, The annual report of the Ladies' AntiSlavery Society, Sheffield 1828, WASC; Sheffield Ladies Anti-Slavery Society, The Fourth Annual Report of the Sheffield Ladies' Anti-Slavery Society, for 1829, WASC; Sheffield Ladies' Anti-Slavery Society, The Annual Report of the Sheffield Ladies' Anti-Slavery Society, for 1830, WASC; Sheffield Ladies' Anti-Slavery Society, East India Sugar, WASC.

${ }^{188}$ Pollard, 29; Reid, "Middle-Class Values and Working-Class Culture in Nineteenth-Century Sheffield," 376, 378.

${ }^{189}$ Twells, The Civilising Mission and the English Middle Class, 101.

${ }^{190}$ Reid, "Middle-Class Values and Working-Class Culture in Nineteenth-Century Sheffield," 394, 399.
} 
the teetotal movement, a group of societies which argued that because all forms of alcohol were dangerous everyone should commit to "total abstinence" from all intoxicants.

In most cities, teetotalism was rejected by the majority of middle-class temperance supporters who favored the "moderate" approach of abstaining from spirits. In Sheffield, however, many middle-class dissenters who were active participants in local philanthropy supported teetotalism. ${ }^{191}$ Sheffield's temperance advocates proved particularly sympathetic to teetotal ideas because of their disillusionment with anti-spirit methods, especially the failure of the Beer Act of 1830, which sought to decrease the consumption of spirits by opening more pubs to encourage beer drinking. In 1834, the Methodist Surrey Street Chapel established the first teetotal society. Instead of creating tensions between teetotalers and moderates, the new teetotal society and the original temperance association cooperated and derived inspiration from each other.

By 1836, the Sheffield Temperance Society essentially behaved like a teetotal organization. Though it condoned abstaining from spirits, it also allowed members to take pledges of total abstinence and invited teetotal speakers like William Cruikshanks to give lectures on the "evils of beer."192 The most common middle-class supporters in Sheffield were reform-minded manufacturers and industrialists like the Ibbotsons who held teetotal meetings in the company teetotal societies they established for their workers. ${ }^{193}$ Nevertheless, not all middleclass temperance advocates accepted this assimilation: two of the leading figures of the townHugh Parker and James Montgomery-- left the movement in 1835 because they disagreed with

\footnotetext{
${ }^{191}$ Caroline Reid, "Temperance, Teetotalism, and Local Culture: The Early Temperance Movement in Sheffield," Northern History 13, (1977) :248-264, 248. Reid also credited the role of Nonconformity in Sheffield.

192 Reid, "Temperance, Teetotalism, and Local Culture," 256; Reid, "Middle-Class Values and Working-Class Culture in Nineteenth-Century Sheffield," 400.

193 Reid, "Temperance, Teetotalism, and Local Culture," 257.
} 
total abstinence. ${ }^{194}$ When asked if he would take the pledge of total abstinence, Montgomery quipped that "he was not sufficiently perfect in the ten commandments to be prepared to enter upon an eleventh." ${ }^{195}$ Even without the aid of influential men like Parker and Montgomery, Sheffield's temperance movement persevered. After 1836, the Sheffield Temperance Society embraced teetotal ideas and in 1841 it changed its name to the Sheffield Total Abstinence Society. ${ }^{196}$ Though Joseph Read and his family were teetotalers, there is not any evidence that they were members of the town's temperance organizations. Chapter four will therefore compare and contrast the family's teetotal activism to explain the Reads' lack of involvement in the city's organization.

Providing children with a moral education remained a key goal of many philanthropists in Sheffield in order to prevent children from falling into destructive habits like the abuse of alcohol. To diminish the influence of immorality, irreligion, and ignorance among the working poor, children needed a moral, religious education. Due to the absence of any comprehensive educational system for lower-class youth, Christian middle-class activists established educational enterprises like Sunday Schools. Middle-class ideals about the proper religious and moral values shaped Sunday Schools' goals. Especially prevalent in northern industrializing towns, Sunday Schools were a key source of providing basic education as well as religious principles. These schools taught biblical lessons, reading, and writing in the hopes of inspiring deep, personal piety amongst the students. ${ }^{197}$ These schools had the potential to empower their charges by teaching literacy and basic math skills; yet, the curriculum also indoctrinated students with such crucial

\footnotetext{
194 Reid, "Temperance, Teetotalism, and Local Culture," 257.

195 Reid, "Middle-Class Values and Working-Class Culture in Nineteenth-Century Sheffield," 401.

196 Reid, "Temperance, Teetotalism, and Local Culture," 256.

${ }^{197}$ K. D. M. Snell, “The Sunday School Movement in England and Wales: Child Labour, Denominational Control, and Working-Class Culture," Past and Present 164, no. 1 (1999):122-168, 123, 130.
} 
values as discipline, self-control, regularity, industriousness, thrift, and sobriety, which were all suitable behaviors for responsible, docile employees. ${ }^{198}$ The high percentage of middle-class manufacturing families who established and participated in these schools suggests that their family enterprises benefited from these lessons as businesses that relied on working-class labor. $^{199}$

It is important to note that Sunday Schools were not designed to provide the working classes with agency. If some children benefited from the skills they learned and became prominent members of society like chief magistrates, master cutlers, presidents of the National School Union, musicians, doctors, and missionaries, most were expected to learn "selfreliance."200 Sunday Schools therefore were heavily influenced by middle-class views on poverty and forbearance and their own class-centric understanding of working-class hardships. The moral qualities and religious teachings they espoused were not provided as a means to help the working classes advance themselves, but to teach them to "bear their lot with resignation."201 The basic education that working-class children gain helped them to better themselves through reading the Bible and living a respectable, pious life — not to provide them with an education to join or compete with the middle classes.

Sheffield gained a reputation for establishing various large Sunday Schools for its numerous denominations in the nineteenth century. In order to facilitate cooperation and interaction amongst these schools, James Montgomery, George Bennet, and other influential middle-class men established a Sunday School Union during a meeting at the Queen Street

\footnotetext{
198 Reid, "Middle-Class Values and Working-Class Culture in Nineteenth-Century Sheffield,” 233; Snell, $129-30$.

199 Reid, "Middle-Class Values and Working-Class Culture in Nineteenth-Century Sheffield," 171.

${ }^{200}$ Ibid., 174.

${ }^{201}$ Reid, "Middle-Class Values and Working-Class Culture in Nineteenth-Century Sheffield," 159; See also Twells, The Civilising Mission and the English Middle Class, 75.
} 
Congregational Chapel. ${ }^{202}$ The Reads played an active part in this organization as their Sunday School at Wincobank Hall participated in the Union and their father, Joseph, served as its president in 1823 and 1825 . The Sunday School Union addressed the need to stimulate collaboration across denominational lines by creating a "federation of the Sunday Schools associated with the Congregationalist and Methodist chapels in Sheffield." ${ }^{203}$ The goal of the Sunday School Union was to link all of the Sunday Schools in the city.

The Union attempted to standardized education by establishing "religious exercises" that would consolidate these schools' teachings. The connection between its members was maintained through anniversary meetings, half-yearly lectures, quarterly committees, and monthly prayer meetings. ${ }^{204}$ By 1824 , the Union reported the success of its work to the city in the Iris. As president, Joseph claimed that the society actively promoted the cooperation of different congregations due to the motivation of the Holy Spirit and that the yearly report illustrated the success of these aims of cooperation for "the active agents of this Union." 205 His presentations on the society in 1823 and 1825 acknowledged the difficulties facing the society which had failed to completely suppress vice in the town. He was particularly concerned with finding ways to eradicate "juvenile wickedness and Sabbath violation" within the community. ${ }^{206}$ Two schools, not specified by the author, were established in "the centre of a wild population [amongst] a Sodom-- notorious throughout the country for excesses of all kinds.” These schools were originally rejected by the community, but with the perseverance of its workers, the institution and its instructors were eventually accepted "as angels from heaven." ${ }^{207}$ Though

\footnotetext{
${ }^{202}$ Reid, "Middle-Class Values and Working-Class Culture in Nineteenth-Century Sheffield," 172.

${ }^{203}$ Twells, The Civilising Mission and the English Middle Class, 55.

204 "The Sunday School Union," Sheffield Iris, Tuesday, May 10, 1825.

205 "Sunday School Union," Sheffield Iris, Tuesday, May 27, 1823.

${ }^{206}$ Ibid.

207 “The Sunday School Union,” Sheffield Iris, Tuesday, May 10, 1825.
} 
Joseph's reports suggest that the middle classes asserted hegemonic moral authority over lower class communities through these schools, Mary Anne's reflections on the schools' religious purpose reveals the depth of spiritual conviction behind her family and philanthropic cohort's Sunday School activism.

The Sunday School Union played a pivotal part in these early initiatives for workingclass adult education until the mid-1820s. It included Sunday Schools sponsored by Nonconformist congregations like the Queen Street, Sycamore Street, Howard Street, and Garden Street Chapels, as well as the Wesleyan Methodists of Red Hill and Handworth Woodhouse. These attempts collectively taught two hundred and seventeen working-class adults. ${ }^{208}$ By 1824, the Union included " 48 Schools, 8,854 Scholars, 2,039 Teachers, which was three times the number as upon its formation. ${ }^{209}$

Mary Anne's accounts of the Sunday School Union depicted it as an entity that emphasized the importance of individual salvation, repentance for sin, and Christian forgiveness and sympathy. Her inclusion of her mother, Elizabeth's, recounting of James Montgomery's decision not to cast out a "bad" student at the Methodist Red Hill Sunday School after he had been caught stealing represented a Christian act modeled on God's forgiveness and offers insight into these figures' piety. ${ }^{210}$ As Montgomery explained to the Sunday School teachers, he could not in good conscience "banish this poor boy from the school [when Montgomery himself had] so often rebelled against the will of my Heavenly Father-[had] broken his laws, \&... wandered far from Him." ${ }^{211}$ According to Elizabeth Read's retelling, Montgomery's compassion and deep desire that his own sins should be forgiven touched the student so deeply that he "confessed [to

\footnotetext{
${ }^{208}$ Reid, "Middle-Class Values and Working-Class Culture in Nineteenth-Century Sheffield," 202-3.

209 "The Sunday School Union," Sheffield Iris, Tuesday, May 10, 1825.

${ }^{210}$ Mary Anne Rawson, “Memorials of James Montgomery,” JMC, SUA.

${ }^{211}$ Ibid.
} 
the crime,] implored forgiveness, \& ... gave evidence of being an entirely changed character. ${ }^{212}$ The fact that Elizabeth Read wrote this story down after hearing of it and her daughter, Mary Anne, included it in her celebration of Montgomery's life proves that the event moved both women and suggests that Montgomery and the Reads shared common religious convictions. This concept particularly suits evangelicals' emphasis on inward religion and Christ's atonement for our sins via his crucifixion and Congregationalist understandings of God as "loving, caring, and forgiving." 213 This decision to model piety and faith using his own failings suggests that Montgomery and the Reads' Sunday School work did not conform to other scholarship on Sunday Schools which depicts middle-class activists as driven purely by self-interest. ${ }^{214}$ Furthermore, it reflected evangelicals' and Congregationalists' emphasis on acknowledging one's sins and recognizing the power of God's salvation and grace, and his unceasing love and forgiveness for all sinners. $^{215}$

Like Sunday Schools, Lancastrian Schools were popular educational institutions that promoted middle-class principles as part of their educational curriculum. Joseph Lancaster established a program of education in 1798 which became known as the Lancastrian schools and dominated working-class education in nineteenth-century Britain and the United States. Lancaster's system was inspired by Andrew Bell's Madras School, as outlined in Bell's book Experiment in Education (1798). In Experiment in Education, Bell recounted how he was able to provide cheap and basic education for poor boys by assigning students as "assistants" to help teach other children and by using cost-effective methods like using sand on tables to teach

\footnotetext{
${ }^{212}$ Mary Anne Rawson, "Memorials of James Montgomery,” JMC, SUA.

${ }^{213}$ Brunner, 79; Isabel Rivers, "Inward Religion and Its Dangers in the Evangelical Revival," in Heart Religion: Evangelical Piety in England and Ireland, 1690-1850, ed. John Coffey (Oxford: Oxford University Press, 2016), 155; Hopkins, 249-50; David Bebbington, Victorian Nonconformity, 12.

214 This phenomenon is best seen when compared to works that study the broader Sunday School movement like Snell's. Snell, "The Sunday School Movement in England and Wales."

215 Bebbington, Victorian Nonconformity, 3-5; Hall, "The Sweet Delights of Home," 60-1; Hopkins, $249-50$.
} 
writing, reading, and arithmetic rather than purchasing "slates and paper."216 Lancaster

streamlined this process by teaching reading and writing simultaneously. Lessons in these subjects were taught through the identifying "syllables" which made up the words instead of its individual letters. This was also a cost-effective method because these lessons were printed on charts held by monitors at the front of the classroom. These charts saved the expense of requiring each student to have his own textbook. ${ }^{217}$ It was thus described as an efficient and economical way to provide the working classes with a basic education.

Due to its popularity and success, a Lancastrian school was established in Sheffield in 1809. Despite the fact that it was organized by dissenters, the school featured both Nonconformist and Anglican students of both sexes until the Anglicans established their own school, the National School in $1813 .{ }^{218}$ Like Sunday Schools, Lancastrian schools reformed working-class children from "idle and insolent" beings to individuals with "diligence, steadfastness, and integrity." 219 In 1815 , the town created a separate school for girls, the Lancastrian Girls' School, which focused on readying its pupils to fulfill their proper domestic roles as wives, mothers, and domestic servants. ${ }^{220}$ The Girls' School particularly stressed their duty to watch over their male family members by guarding them against the allure of the pub. ${ }^{221}$ Both schools promoted their hard work and success in transforming working-class children into respectable charges, as seen in testimonies of the students' "simple and intelligent manner.",222

\footnotetext{
${ }^{216}$ P.M. Zall, "The Cool World of Samuel Taylor Coleridge: Joseph Lancaster's System," The Wordsworth Circle 13, no. 2 (1982): 91-93.

217 Ibid.

218 Twells, The Civilising Mission and the English Middle Class, 62.

${ }^{219}$ Ibid., 68.

${ }^{220}$ Ibid., 65. See also Meg Gomersall, "Ideals and Realities: The Education of Working-Class Girls, 1800-1870," History of Education 17, no. 1 (1988): 37-53, 42.

${ }^{221}$ Twells, The Civilising Mission and the English Middle Class, 69. Though Twells does not specifically address teetotalism, this idea will play a vital role in chapter four.

222 “The Iris," Tuesday, March 14, 1817. The boys' school was also demonstrating the learning of its students before its meeting on June 19, 1823. See "Sheffield Lancasterian School for Boys," Sheffield Iris, Tuesday, June 17, 1823.
} 
The Reads and their philanthropic network of friends and family performed pivotal roles within Sheffield's Lancastrian Schools. Joseph served as a committee member for the Boys' School in 1821, 1822, and 1825 and acted as the treasurer, chairman, and "member for life" in the Girls' School in 1827-28. ${ }^{223}$ James Montgomery also held the position of treasurer of the Girls' school for most of the institution's existence. ${ }^{224}$ Joseph Read's wife, Elizabeth, also supported the Girls' School, acting as an "Honorary Member" and committee member. Similarly, male and female members of the Reads' kinship network, the Shores, held posts as committee members, "Honorary Members," and "Members for Life."225 By analyzing the Reads" role in industry and civil society and placing them within their middle-class dissenter cohort, this chapter has highlighted the role of dissenter families like the Reads in transforming Sheffield into a prominent industrial center as well as a site of philanthropical activism that included men and women committed to the educational and moral improvement of their city and its residents.

\section{Conclusion}

Much like Frankenstein's monster, industry brought manufacturers power and influence while simultaneously creating problems beyond their ability to resolve, such as pollution, working-class poverty, and immorality. If Mary Anne, who lived in the paradise-like countryside

\footnotetext{
And, in December of 1823 and June of 1825, the boys and girls school presented their accomplishments together in an examination on December 23, 1823. See "Sheffield Lancasterian Schools," Sheffield Iris, Tuesday, December 16, 1823. See also Sheffield Lancasterian Schools," Sheffield Iris, Tuesday, June 14, 1825.

223 "Lancasterian Boys' School," Sheffield Independent, June 30, 1821, BNA; "Lancasterian Boys' School," "Lancasterian Boys' School," Sheffield Independent, June 21, 1828; 223 "Lancasterian Boys' School," Sheffield Independent, June 29, 1822, BNA; "Lancasterian Boys' School," Sheffield Independent, March 19, 1825 BNA; "Lancasterian Girls' School," Sheffield Independent, March 15, 1828, BNA; "Girls' Lancasterian School of Industry, Sheffield Independent, March 17, 1827, BNA.

${ }^{224}$ Mary Anne Rawson, "Memorials of James Montgomery," JMC, SUA. Mary Anne claimed that he was treasurer from its creation to his death, however, newspaper reports show that her father, Joseph Read, was treasurer of the Girls' school in 1827-8. See footnote above.

225 “'Girls' Lancasterian School of Industry, Sheffield Independent, March 17, 1827, BNA. Mr. and Mrs. Shores from Deersbrook and Norton were "Members for Life" and Mrs. Shore of Deersbrook and Mrs. Shore of Tapton were "Honorary Members." Though they were not linked by kinship to the Reads or Montgomery, the Gale Sisters, who lived with Montgomery at the Hartshead, appear to also be committee members.
} 
of Wincobank Hall felt so much disgust at the conditions in the city, how much more must those who had to live there - especially the working classes who could not as easily escape it - have suffered from the results of rising industrial influence. As the opening vignette suggested, the Reads' unique experiences provide a vantage point to analyze the development of middle-class culture in late eighteenth- and nineteenth-century Sheffield.

The Reads' lives can only be fully understood within the wider national and regional social, cultural, and political circumstances that shaped them. This chapter observed the liberal, radical culture of Nonconformist manufacturers in nineteenth-century Sheffield to demonstrate how Sheffield both conforms and deviates from the traditional narrative of industrialization in England. The rise of a manufacturing middle class played an integral role in the town's transition from an obscure place without any of the comforts of civil society where only a small number of basic pieces of cutlery were made into an industrial urban center complete with a rich associational life and culture. As this chapter has shown, a decrease in aristocratic control and interest in the town and increase in middle-class interests and participation in local affairs through institutions like the Cutlers' Company, Church Burgesses, and Town Trustees facilitated this transformation. Once manufactures were free from the restrictions of the landed elites, industry flourished amongst not only the cutler trade but also in the discovery of silver plate in. Such an environ was the perfect situation for Grandfather John to settle and establish the first smelting works in the city.

In addition to seeking out their economic self-interests, middle-class dissenters also pursued a larger role within the community as a way to fight back against their exclusion from national politics. The Test and Incorporation Acts made it impossible for Nonconformists to hold political office unless they were willing to renounce their faith by taking Anglican communion. 
Resentment and indignance therefore drove many male dissenters to engage in the city's local governing structures as a means to prove their capacity and ability for political participation and demonstrate their dedication to the betterment and protection of their community. The same sense of discontent also inspired an acceptance and interests in radical, liberal politics in late eighteenth- and early nineteenth-century Sheffield. Sympathy for political reform and expanded suffrage for men created common ground between the middle classes and the working classes: the middle classes promoted extended political participation for property owners and the working classes demanded universal male suffrage.

The rising influence of middle-class manufacturing and commercial interests and resulting growth of industry within Sheffield also led to Sheffield becoming a dirty, crowded unpleasant place to live for the middle and working classes alike. Development in the cutlery manufactory and other industrial trades due to the advent of steam power led to terrible conditions in the working-class slums of Ecclesall and Nether Hallam and the back-to-back houses at Endcliffe. Deterioration of urban living condition, particularly for the working classes, compelled the middle classes to take an active interest in providing services to make life more pleasant in the city and to address social issues like working-class poverty, irreligion, and immorality.

Associational life and civil society played a vital part in the emerging middle-class identity within the town by providing them with an outlet to address local, national, and international problems while simultaneously reinforcing their position. Middle-class philanthropic work asserted their roles as moral authorities by championing a set of values increasingly becoming associated with this section of society. These principles served as a unifying force amongst otherwise disparate religions, professions, and localities that helped to 
create the concept of a middle-class identity and acted as a one stop solution to all of the evils of urban, working-class life — at least according to the middle-class perspective. Middle-class men and women's work in the Society for Bettering the Condition of the Poor, Bible Societies, antislavery societies, temperance organizations, Sunday Schools, and Lancastrian Schools utilized ideas about proper domestic life, family security, ignorance, irreligion, and immorality to reform the working classes while elevating their own worldviews and principles.

This scholarly framework should not, however, displace the integral role of a deep, spiritual faith within many of these individuals' lives. Many works on middle-class religious outreach in Bible Societies and Sunday Schools assume that these associations were merely a means to promote their self-interests. The Reads and their philanthropic cohort's example, however, reveal that an emphasis on inward spirituality, based upon their own reliance on Christ and the necessity of attaining spiritual salvation, drove their actions and services within these societies. These characteristics situate the Reads' and their philanthropic network within a larger culture of Nonconformity and evangelicalism that stressed the importance of individual conversion, personal salvation, and God's unfailing love and mercy. Scholars must therefore reconcile both the religious beliefs and altruistic attitudes that drove these endeavors with the potential for middle-class aggrandizement and social power. The following chapters in this dissertation will demonstrate how this cultural, political, and social background shaped the Reads' religious, cultural, professional, and charitable lives in case studies of the family's business and domestic philanthropic activism at Wincobank Hall. 


\section{Map of Wincobank, Including Wincobank Hall}

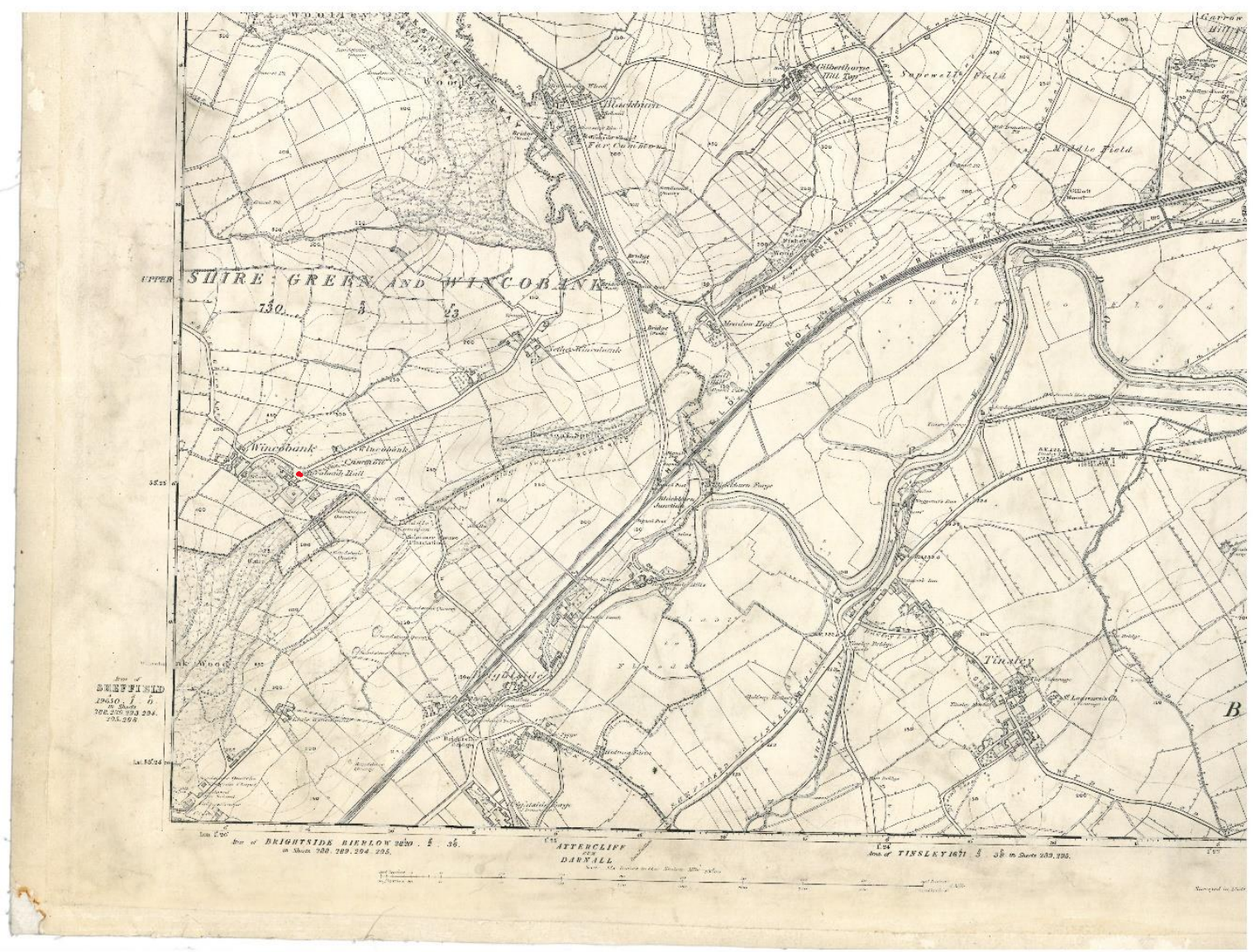

Image Courtesy of Sheffield City Archives: Ordinance Survey Map Collection 


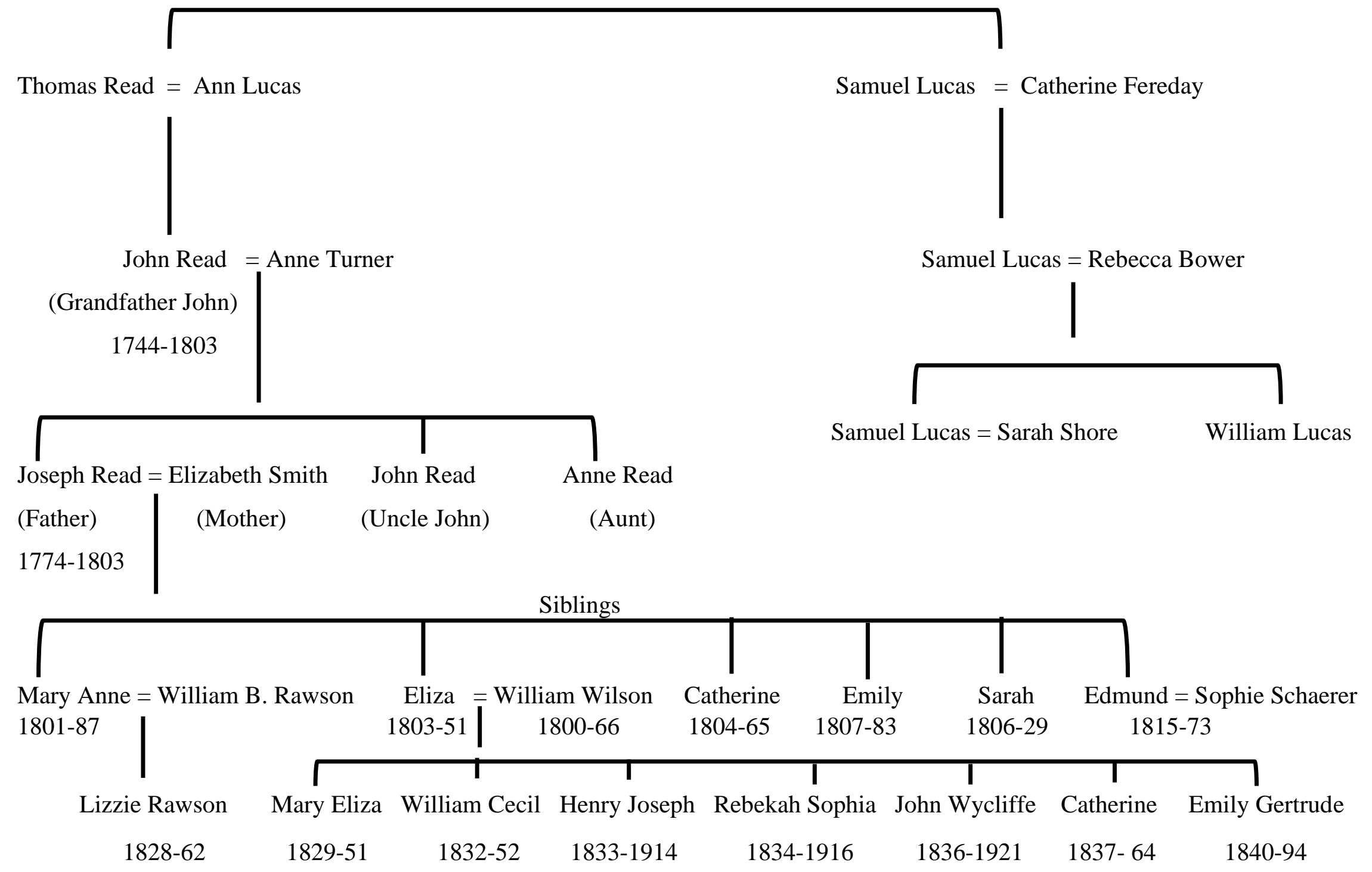




\section{Chapter 2}

For Richer or Poorer: Family Networks, Household Strategy, and Gender Roles in NineteenthCentury Business, 1820-1837

"In a field, about a score yards from the residence of Joseph Read, Esq." stood a “curiosity" that sparked local interest: "two large trees, an oak and an ash [which were] planted so close together, that their roots [were] completely grown into one compact boss; their expansive heads...so intimately ramified into each other, that the whole ha[d] the appearance of a single tree." With masterful artistry, a poet dubbed this phenomenon, "The Conjugal Trees" for its structure's embodiment of marriage which “year by year... added strength [and] new charms." 226 Though the poet was inspired by the likeness between the union of these two trees and the marriage of individuals, marriage likewise represented the formation of new ties between two families. Therefore, it is fitting that this poem utilized trees as a symbol of marriage because trees are also synonymous with family lineages.

Family ties were indispensable for promoting and protecting a family's financial interests, particularly in an era when many fathers, sons, and even cousins tarried on in the same enterprise. Consequentially, marriage was an important source of revenue and network formation that could advance family goals. Not all investments or connections were stable, however, and some marriage ties placed individuals and households in a state of risk and insecurity. Just as the image of intertwining roots could symbolize strength and stability, it could also signify duty and obligation. Conjugal unions created affinal links (those ties created by marriage) that sometimes

\footnotetext{
${ }^{226}$ Newspaper clipping, "Poetry. The Conjugal Trees," Mary Anne Rawson Collection (hereafter MAR), MD 6041, Sheffield City Archives (hereafter SCA).
} 
bound individuals with a commitment to support their in-law's professional, economic, and business ventures. Much like individuals pledged vows to take one another for richer or poorer, the Reads' kin ties reveal that investment in family businesses sometimes led to ruin rather than prosperity.

\section{Survey of Scholarship on the Family and Family Businesses}

Recent scholarship acknowledges the importance of family networks by reevaluating the implications of a progressive narrative that tied the rise of the nuclear family in the eighteenth and nineteenth centuries to the birth of modern Western life. This historiographical shift began when scholars like David Warren Sabean challenged Lawrence Stone's argument about the primacy of the nuclear family over the extended family and community by utilizing comprehensive studies of family networks to prove that the three actually coexisted. ${ }^{227}$ As more scholars contested the primacy of the nuclear family, it became increasingly apparent that assumptions about modernity, civilization, gender, and identity had skewed the study of the family. These presuppositions relied on an romanticized interpretation of the nuclear family and male-breadwinner in the modern, industrial world that overemphasized the prominence of a standard (yet inaccurate) archetype of the nuclear family; celebrated the impact of the individual's freedom from oppressive obligations to their extended kin as a symbol of modernity; and glorified the public sphere as the "progressive, male world of the modern economy" whilst relegating kinship and the domestic sphere to a "private, female, and primitive" world of little scholarly interest. ${ }^{228}$

\footnotetext{
${ }^{227}$ Stone; Sabean, Kinship in Neckarhausen, 2-3, 10-11, 19, 23; Grassby, 2; Sabean and Teuscher, 2-3, 20, 24. Sabean's work illustrated that loosening regulations of affinity (degree of blood relation between the couple) during the nineteenth century led to more unions between cousins and in-laws, which resulted in "endogamous marriages" that created networks of shared assets like capital, property, and influence. See, Sabean and Teuscher, 21.

${ }^{228}$ Davidoff et al., The Family Story, 4-5, 16-18, 23-5, 68; Sabean, Kinship in Neckarhausen, 2-3; Sabean and Teuscher, 1, 23; Sylvia Yanagisako, "Bringing It All Back Home: Kinship Theory in Anthropology," in Kinship in
} 
Studies of eighteenth- and nineteenth-century family networks played a central part in this revisionist scholarship. This work has shown that these alliances enabled families to accrue the capital, credit, and personnel necessary to capitalize on opportunities in "mining, metallurgy, textile production, and international trade" as they simultaneously combated the alienating experiences of urbanization and industrialization. ${ }^{229}$ Business ventures became inseparably connected with these families' identities as a "capitalist, bourgeois class," providing the middle classes with the respectable vocations necessary to transform work from a demeaning economic necessity to a source of pride symbolic of their loving, dedication to their families. ${ }^{230}$ In addition to economic benefits, family networks also secured important bonds that offered stability and safety in the rapidly changing atmosphere of industrial commerce and business. The extended family, therefore, was not a "liability;" rather, it was a key resource which distributed "risks.",231

The family's shared needs and interests generally ensured a spirit of cooperation known as reciprocity-- the performance of services that promoted the family network's goals in exchange for corresponding support of one's own interests within this purpose or agenda. ${ }^{232}$ When mutual benefit failed, family members used the affective bonds that united them, offering advice, opinions, suggestions, or reproofs couched in a language of love or 'dutiful feelings' in order to coerce family members into fulfilling their obligations to the network. ${ }^{233}$ My work seeks to demonstrate the utility of this language as a means to enforce the ties of love, duty, and

\footnotetext{
Europe: Approaches to Long-Term Development (1300-1900), eds. David Warren Sabean, Simon Teuscher, and Jon Mathieu (New York: Berghahn Books, 2007), 42-3.

${ }^{229}$ Sabean, Kinship in Neckarhausen, 36; Sabean and Teuscher, 12-13, 17, 24; Holland, "A Family Affair," 29; Barker, 123; Morris, Men, Women, and Property in England, 57; Cookson, 1. Cookson notes that this was also true for members of the same religious denomination or philanthropic societies.

${ }^{230}$ Davidoff et al., The Family Story, 106; Newbon, 132; Gunn and Bell, 6-7; Hunt, 47; Wilson, Sense of the People.

${ }^{231}$ Sabean and Teuscher, 20, 22; Sabean, Kinship in Neckarhausen, 2-3, 36; Cookson, 1.

${ }^{232}$ Duncan 17; Barker, 128.

${ }^{233}$ Barker, 79, 97, 111, 117, 152; Sabean, Kinship in Neckarhausen; Davidoff et al., The Family Story, 77.
} 
obligations in affinal relations by studying the exchange of correspondence among brothers-, sisters-, and mothers-in-law.

In addition to complicating the narrative of the nuclear and extended family, my work seeks to contribute to a recent debate within masculinity scholarship that analyzes the connection between men's public life and private, familial roles. Groundbreaking works of gender scholarship like Family Fortunes argued that middle-class men drew on their status as protectors of familial dependents to advocate for a role in the public sphere of politics and philanthropy; and, that consequently their public roles were more prominent in their identity formation and social status. ${ }^{234}$ Current studies of masculinity and the public sphere reveal, however, that men's professional and civic roles were directly connected to their familial responsibilities as protectors of dependents; i.e. that their professional roles were also their family roles. ${ }^{235}$ The duality of men's familial roles stemmed from the inherently gendered nature of eighteenth- and nineteenthcentury conceptions of the public and private. ${ }^{236}$ Whereas, the "naturally" private nature of femininity and motherhood (at least ideologically) appeared to relegate women to domestic and family concerns; men's masculine status as protectors of dependents traversed their public and private roles, making fatherhood and "household authority" simultaneously characteristics of their "domestic" and professional lives. ${ }^{237}$ Joanne Bailey demonstrated this point in her analysis of conceptions of fatherhood, which isolated "provisionary fatherhood"-- men's responsibilities

\footnotetext{
${ }^{234}$ Davidoff and Hall, Family Fortunes; Wilson, Sense of the People; Davidoff et al., The Family Story.

${ }^{235}$ Davidoff et al., The Family Story, 53, 67, 77, 79; Matthew McCormack, "Men, 'the Public' and Political History," in Public Men: Masculinity and Politics in Modern Britain (Basingstoke, Hampshire: Palgrave Macmillan, 2007), 22; Tosh, "The Old Adam and the New Man," 223, 238; Hunt, 4, 47, 49; Bailey, 171, 173, 176, 178-9; Newbon; John Tosh, "The History of Masculinity: An Outdated Concept?," in What Is Masculinity? Historical Dynamics from Antiquity to the Contemporary World, eds. John Arnold and Sean Brady (Basingstoke, Hampshire: Palgrave Macmillan, 2011); Davidoff et al., The Family Story, 151.

${ }^{236}$ McCormack, "Men, 'the Public', and Political History," 22.

${ }^{237}$ Tosh, "The Old Adam and the New Man," 217-8, 223, 238; Davidoff \& al., The Family Story, 151.
} 
to fulfill their family's basic and material needs-- as the most accepted model of this familial role. $^{238}$

This definition of masculinity was not exclusively applicable to father as sons were also expected to contribute to their family's finances. Sons were, therefore, valued for their ability to complement or bolster the family networks through their personal professionalism, thriftiness, and hard work or castigated for the pursuit of frivolous interests like fashion, drinking, gambling, and whoring that undermined their family's larger interests. ${ }^{239}$ My case study seeks to elaborate upon this point by demonstrating how the implication of one's masculine responsibilities influenced men's personal reputations.

Recent scholarship has claimed that, throughout the nineteenth century, men's personal, moral standards became increasingly associated with their public, professional success. Tosh argued that this phenomenon was the result of a convergence of two formerly independent social perceptions-- man's personal or inner "character" and his external "reputation"-- into a united concept of professional and "moral integrity." ${ }^{240}$ Accordingly, professional success became increasingly hinged on personal qualities that had little to do with one's professional "aptitude," such as “constancy, firmness, defiance, temper, sincerity, and good faith." ${ }^{241}$ Men's professional roles also provided them with the financial means to fulfill their private duties as protectors of dependents whilst granting them an arena to assert their independence from external control and display their professional aptitude. ${ }^{242}$ During the economically tumultuous Industrial Revolution, however, not all middle-class men enjoyed professional success. This chapter will further

\footnotetext{
${ }^{238}$ Bailey, 171, 173.

${ }^{239}$ Hunt, 4, 47, 49-50.

${ }^{240}$ Tosh, "The Old Adam and the New Man," 235.

${ }^{241}$ Matthew McCormack, "Introduction," in Public Men: Masculinity and Politics in Modern Britain, ed. Matthew McCormack (Basingstoke, Hampshire: Palgrave Macmillan, 2007), 4. The popularity of Evangelical Revival, the "Protestant work ethic," and "christian masculinity" also reinforced these moral standards. See Newbon, 212-3.

${ }^{242}$ Tosh, A Man's Place, 2, 111-2; Newbon, 132.
} 
investigate the emasculating nature of reliance in the context of Joseph and Edmund Read's lives.

Scholars have also acknowledged the importance of women's contributions to their family networks. Alison Duncan, Ruth Larsen, and R. J. Morris' works demonstrate that women played an integral role within family networks as mediators, alliance brokers, patronage negotiators, and advisors and suppliers of crucial resources like capital, property, and domestic management. ${ }^{243}$ Though these tasks appear to contradict the separation of spheres ideology, middle-class women's domestic roles included carrying out acts of reciprocity, such as regular correspondence, social calls, and extended visits, to promote their family networks' political, business, and social interests. ${ }^{244}$ In addition to serving as networkers and promoters, these women sometimes served their family businesses as laborers, managers, clerical workers, informal representatives, and even heads of the company. ${ }^{245}$ This chapter will contribute to this historiography by further illustrating how middle-class women's roles as networkers legitimized their participation in public matters like family businesses. Much like scholarship that acknowledges women's roles within these enterprises, scholarship on family businesses now analyzes the family's centrality within these ventures.

Traditional studies of family businesses assessed these firms using anachronistic business standards. As a result, these older works cited family businesses' inability to endure for more than one generation or amass a fortune as proof of their failure. ${ }^{246}$ Recent scholarship, however, challenges these arguments in favor of acknowledging the crucial role of the family's

\footnotetext{
${ }^{243}$ Sabean, Kinship in Neckarhausen, 2; Morris, Men, Women, and Property in England, 233; Duncan, 11-12; Larsen, 396-7.

${ }^{244}$ Duncan, 11, 17; Larsen, 396; Elisabeth Joris, "Kinship and Gender: Property, Enterprise, and Politics," in Kinship in Europe: Approaches to Long-Term Development, 1300-1900, eds. David Warren Sabean, Simon Teuscher, and Jon Mathieu (Oxford: Bergham Books, 2007), 234; Davidoff and Hall, Family Fortunes, 114-5. ${ }^{245}$ Hunt, 86; Tweedale, 888; Cox, 169; Barker, 103.

${ }^{246}$ Holland, "A Family Affair," 26; Barker, 1; Owens, 23, 41-2.
} 
motivations within their "social, cultural, and political context."247 This work shows that the family's primary incentive in business focused on providing an income for its members and that the expertise it required, its profitability, and the desirability of alternative ventures contributed to debates and discussions about whether to continue the business. ${ }^{248}$ Though family businesses benefitted from shared sources of capital and resources, feelings of "emotional investment" and "family pride" also served as hindrances because they made families less open to beneficial "mergers with other partners or firms." ${ }^{249}$ As this chapter will further illustrate, family indecision and uncertainty about the businesses' future often stemmed from the family's concerns about their reputation and professional legacy. These tensions were only compounded by financial crises and an increasingly competitive economy.

Despite the fact that studies of this period generally focus on the few middle-class families who accrued fortunes from advances in mechanization and production, the most common experience of those who engaged in the competitive market was financial loss and bankruptcy. ${ }^{250}$ Bankruptcy, therefore, serves as a "dark" foil to Victorian propaganda of accomplishment and progress. ${ }^{251}$ Nineteenth-century understandings of bankruptcy asserted that it was both an effect of industrialization's separation of the individual from the family and community and antithetical to Victorian social values like "thrift, self-help, and individual effort." 252 Therefore, contemporaries assumed that bankruptcy was a clear moral failing and that

\footnotetext{
${ }^{247}$ Owens, 24-5, 32, 35; Barker, 33.

${ }^{248}$ Holland, “A Family Affair,” 26, 29; Barker, 11, 33, 123; Owens, 22-5, 32, 35; Morris, Men, Women, and Property in England, 57.

${ }^{249}$ Grassby, 409.

${ }^{250}$ Barbara Weiss, The Hell of the English: Bankruptcy and the Victorian Novel (Lewisburg: Bucknell University Press, 1986), 14, 20; V. Markham Lester, Victorian Insolvency: Bankruptcy, Imprisonment for Debt, and Company Winding-up in Nineteenth-Century England (Oxford: Clarendon Press, 1995), 68.

251 Ibid.

252 Ibid.
} 
only those guilty of "weakness of character" or "dishonesty" would become bankrupts. ${ }^{253}$ By the mid-nineteenth century, however, these attitudes evolved into two distinct responses: sympathy for victims of the "commercial" market who had not committed any unscrupulous actions and harsh punishment for those guilty of fraud and duplicity. ${ }^{254}$ This chapter will utilize the Reads' example to analyze conceptions of bankruptcy through a case study of the family network's reactions to financial crisis.

Building on this rich scholarship on kinship networks, gender, and family businesses, my work illustrates that middle-class financial and business interests were enterprises in which men and women worked together to seek stability, if not prosperity. This chapter will focus on the period of 1820-1837 to examine the role of family networks and gender in the development of the Reads' financial crisis which culminated in the family company's first bankruptcy in 1837. It will therefore place the Reads' example within current scholarship by evaluating their experiences through four elements: reciprocity, professionalization and the family business, family strategy, and bankruptcy.

\section{Read \& Co.: 1760-1834}

The Reads' example demonstrates that businesses in the nineteenth century truly were a family affair. The family owned a smelting works, named Read \& Co., which in proper middleclass fashion thriftily converted sweep (particles left over from the production of gold or silver goods like jewelry) into reworkable pieces of precious metals by separating them from copper, iron, and lead. Read \& Co. was established by Grandfather John who pulled together resources with his maternal uncle, Samuel Lucas, to start a refinery in Sheffield in 1760. The next

\footnotetext{
${ }^{253}$ Weiss, 34-5; Lester, 68.

${ }^{254}$ Lester, 68. Though Lester does not make this point in his work, this principle parallels the increasing interest in distinguishing between those who were eligible for poor relief in the concept of the deserving and undeserving poor.
} 
generation of Reads and Lucases also served as partners; Grandfather John's sons, Joseph (the father of this case study) and Uncle John and Samuel Lucas's son and grandson worked together until the Lucases dissolved their partnership in $1824 .{ }^{255}$ Notwithstanding the Lucases' exit, the Reads' family network continued to heavily influence the family business. In fact, the Reads' decision to support their family network's business interests during a period of warfare and economic strain ultimately led to their own financial troubles.

In 1800, Joseph Read married Elizabeth Smith whose father and brothers owned Smiths' Iron Works of Chesterfield. Though an increased duty on silver in 1797 had caused Read and Co.'s profits to decline during the Revolutionary and Napoleonic Wars, the Smiths' production of "cannon balls and guns" ensured their prosperity at a time when other manufacturing interests suffered. After peace was declared in 1815 , however, Smiths' foundry faltered when they failed to find a new lucrative market of goods to replace wartime artillery. ${ }^{256}$ Unfortunately for the Reads, Joseph became partner in his wife's family business, the Smith's works, in 1816, just as the tide started to turn from profitable to problematic. As partner, he purchased so many "shares" in the Smiths' Iron Works that he became "the largest shareholder" despite not having any managerial influence over the enterprise. His decision to provide so much money to his in-law's business affected the future of Read \& Co. in several ways.

Joseph's financial representation of his filial devotion to his in-laws alarmed his partner at Read and Co, Uncle John, who feared that his brother was investing money in an unprofitable business over which he had little control. In order to establish a means of damage control for his brother's risky investment, Uncle John chose to retire from Read \& Co. in June $1831 .{ }^{257}$ This

\footnotetext{
${ }^{255}$ Wilson, Two Hundred Precious Metal Years, 57,63, 74, 93.

${ }^{256}$ Ibid., 60, 64, 70, 94.

${ }^{257}$ Ibid., $94-5$.
} 
decision was a calculated, tactical move which furthered the extended family's professional goals in several ways. It provided Joseph with a "larger income" to shield his family from his large investment in Smith's iron works; remunerated Joseph with a more appropriate percentage of the profits in proportion to his position's financial risks; enabled Joseph's only son Edmund to take a more active role in the works; and protected Uncle John's fortune so that he could "offer" his brother's family "a home" in the event of financial tragedy. ${ }^{258}$ These motives evince that Uncle John's retirement was a business strategy designed to promote Joseph Read and his nuclear family's interests and provide provisions against the complete ruin of the family network. Retirement held personal benefits for Uncle John as well.

Stepping away from the business allowed Uncle John to accommodate his own tastes and interests. Retiring did not mean entirely detaching himself from the family business; rather, he would continue to invest in the company by providing a bond of $£ 10,000$ in return for the "much smaller" yet "certain income" of a $£ 500$ annuity. ${ }^{259}$ This agreement allowed Uncle John to gain more leisure time and continue to profit from the family's business. With extra recreational time and a steady paycheck, Uncle John could dedicate more energy to his great project: turning his new home, Derwent Hall, into a proper "gentleman's seat" with an impressive library and art collection featuring works by Rubens, Tintoretto, Poole, and Moreland. ${ }^{260}$ This is not to suggest that Uncle John lived an idle life during his retirement. In addition to his cultural pursuits, he was also active in many other business enterprises, serving as chairman of the Company of Proprietors for the Sheffield Canal, director of the Sheffield Banking Company, and chairman of

\footnotetext{
${ }^{258}$ John Read to Joseph Read, July 12, 1830, Sheffield Smelting Company Collection (hereafter SSC), SSC 683, SCA.

${ }^{259}$ John Read to Joseph Read, [Suggested between May 1824 and January 1830], SSC, SSC 683, SCA. See Wilson, Two Hundred Precious Metal Years, 96.

${ }^{260}$ Wilson, Two Hundred Precious Metal Years, 70-1, 106.
} 
the River Dun Company. ${ }^{261}$ These circumstances suggest that Uncle John's retirement represented both personal goals and strategic motives that allowed all members of the family network to benefit. Moreover, it demonstrates that, unlike his brother Joseph's family who dedicated their home, property, and wealth to religious and philanthropic outreach, Uncle John utilized his wealth to pursue a path of conspicuous consumption that elevated his social standing within the town.

Unfortunately for Joseph and his household, Uncle John's concerns about his brother's investment were not unfounded; the Smiths' foundry went bankrupt in 1834, leaving Joseph with a personal loss of $£ 4,541$ and expected to pay further company debts of $£ 16,700 .{ }^{262}$ This created serious complications in Joseph's own finances, in particular his smelting business, that provided a vantage point into the role of family networks in the early nineteenth century.

\section{Case study: Read \& Co. Smelting}

Though the Reads' financial troubles seem exceptional, bankruptcy was a distressing, yet commonplace experience for the many Victorian families who fell victim to consequences of the Industrial Revolution's economic transformations. ${ }^{263}$ Interestingly enough, eighteenth- and nineteenth-century bankruptcy laws only applied to individual traders (businessmen); signifying that this condition and the legal responses to it were directly connected to an emerging and increasingly influential section of society: the urban industrial and commercial elite. ${ }^{264}$ Part of this group's vulnerability to bankruptcy stemmed from their reliance on flawed contemporary methods of borrowing capital and business procedures. In the nineteenth century, the contemporary system of credit allowed individuals to sell their debts to third parties through

\footnotetext{
${ }^{261}$ Wilson, Two Hundred Precious Metal Years, 70, 71, 97, 108.

${ }^{262}$ Ibid., 93, 95.

${ }^{263}$ Weiss 24, 26; Lester, 286.

${ }^{264}$ Lester, 2,4, 21; Weiss, 27-8, 43.
} 
practices like revolving credit, standing overdrafts, bills of exchange, commercial bills, and accommodation bills. ${ }^{265}$ When institutions like the London houses, which assumed responsibility for "large" numbers of these bills, failed, it created a "domino effect" of local or even national calls for payment. ${ }^{266}$

Similarly, unlimited liability drove many families into bankruptcy. This policy was designed to defer speculation by requiring any person who held a "share" in a business to be "responsible for" the company's "debts "to his last shilling and his last acre." ${ }^{267}$ Though there are not any direct references to unlimited liability in the Reads' correspondence, the family's description of the events leadings up to their bankruptcy in 1837 suggests that this may have been the origin of the Reads' financial problems. By the 1860s, societal concerns about unlimited liability's detrimental impact on families who lost their homes and property outweighed its utility as a policing tool. ${ }^{268}$ Consequently, it was replaced by limited liability which ensured that shareholders were only answerable for a percent of the debt equivalent to their investment. ${ }^{269}$ In concordance with the literature on masculinity, this alteration protected middle-class men's abilities to act as protectors of dependents by qualifying that they would only risk as much as they ventured to gain. Based on these circumstances, the Reads' model offers a crucial, yet perhaps unrecognized aspect of life during this period: social status was not necessarily static; rather, households were capable of rising, declining, and alternating between the two sporadically within their lifetimes. ${ }^{270}$

\footnotetext{
265 Weiss, 25-6; Francesca Trivallato, The Promise and Peril of Credit: What a Forgotten Legend About the Jews and Finance Tells Us About the Making of European Commercial Society (Princeton: Princeton University Press, 2019), 2-3.

266 Weiss, 26.

${ }^{267}$ Ibid., 23, 33.

${ }^{268}$ Davidoff et al., The Family Story, 106.

${ }^{269}$ Ibid.

${ }^{270}$ Barker, 7.
} 
The Reads' family network demonstrates that men and women worked together using their gendered, kin roles (fathers, mothers, brothers, sisters, in-laws, etc.) to come up with solutions to the family's problems. Correspondence demonstrates that women drew upon their filial ties to advocate for the business' interests on behalf of their family; whereas men focused on their masculine roles as professionals and familial duties as household providers to advance the family's goals. ${ }^{271}$ The family's actions in the aftermath of the Smith foundry bankruptcy demonstrate how men and women used their family networks to reestablish fiscal stability.

When seeking to address the family's financial problems, archival evidence shows that the Reads manipulated ideas about filial devotion and obligation to compel members of their kinship network into action. These sources demonstrate that middle-class women were not excluded from the world of business; rather, they harnessed their domestic roles to endorse family security or the interests of their male family members by engaging in acts of reciprocity like exchanging letters, social calls, and gifts. ${ }^{272}$ Though not serving any formal role in the family business, the Reads' female family members were important resources in their family network as demonstrated through the example of Joseph Read's spinster daughter, Catherine.

Middle-class single women like Catherine Read were pivotal agents who operated as gobetweens in their family networks. Catherine served as a link between her brother-in-law, William Wilson ${ }^{273}$, and her male family members thanks to her unique experience living for extended periods with her parents in Sheffield and with the Wilsons near Nottingham. Her frequent presence in both households made her an asset to the family network by enabling her to

\footnotetext{
${ }^{271}$ Catherine Hall also argued that women's ability to fulfill their gendered roles in the family granted them "influence" over men who must listen to their advice and appeals out of respect for their excellence in womanly domestic and familial matters. See Hall, "The Sweet Delights of Home," 59.

${ }^{272}$ Davidoff and Hall, Family Fortunes, 114-5; Joris, 234; Duncan, 17.

${ }^{273}$ William Wilson is referred to as Wilson throughout this project to differentiate him from Joseph Read's other son-in-law, William Bacon Rawson, and his second cousin, William Lucas, as well as to avoid the awkward appellation, son/brother-in-law William.
} 
negotiate on both parties' behalves. Tellingly, she played a crucial part in the first phase of the family crisis.

The Reads' financial troubles started in February 1834 when the Sheffield Banking Company's board of directors became apprehensive about "an overdraft" of $£ 10,198$ and asked Joseph to "mortgage... his freehold property at Wincobank and leasehold property at the Mills." ${ }^{274}$ A little over a year later, in March 1835, the bank continued to have concerns about the family's debts and demanded a reduction of the amount owed. Unsure of how to address these calls for further action, the family reached out to Wilson, the owner of a prosperous cottonspinning mill in Nottingham, for advice. ${ }^{275}$

In March 1835, Catherine wrote to her brother-in-law expressing her father's anxieties about the bank's request for further payment. Joseph felt unprepared to negotiate independently with them because he did not trust the bank to advise a course of action which would be most beneficial to the family. For this reason, Catherine wrote on her father's behalf, asking Wilson to visit and offer counsel. ${ }^{276}$ Though the letter is unclear about why Catherine wrote instead of Joseph, Joseph's increasing illness from 1834 suggests that he may have been too unwell to address Wilson himself. In such a case, it would be natural for Catherine to aid him by writing in proxy. ${ }^{277}$ Joseph's illness would also explain his inability to direct the situation. If this were true, it would also make sense that Joseph would feel uncomfortable writing a letter that would emasculate him by beseeching another man for help and admitting his own inabilities.

\footnotetext{
${ }^{274}$ Wilson, Two Hundred Precious Metal Years, 96.

${ }^{275}$ Ibid., 94 . Family correspondence also attests to Wilson's wealth and respectability by evidencing that the Wilsons employed more than three male servants in October 1831 and sought out governesses for their family, which included seven children by 1840, in 1833 and c. 1841. See Catherine Read to Joseph Read, Radford, October 11, 1831, MAR, MD 5694, SCA; Catherine Read to Mary Anne Rawson, Radford, September 22, 1831, MAR, MD 5694, SCA; Catherine Read to Mrs. Elizabeth Read, Radford, April 16, 1833, MAR, MD 5694, SCA; Catherine Read to Anne Read, Torquay, May 3, [Suggested 1841 or 1842], MAR, MD 5694, SCA.

${ }^{276}$ Catherine Read to William Wilson, March 12, [Suggested 1835], SSC, SSC 738, SCA.

${ }^{277}$ Hunt, 86.
} 
Catherine's correspondence allowed Joseph to take advantage of her feminine role as a compassionate and concerned daughter to implore Wilson to honor his obligations to his in-laws. It appears that the results of Catherine's plea and subsequent negotiations with the bank led to stricter measures of retrenchment in the family economy. Within the next two months, the Reads left Wincobank Hall, their home in the countryside, and returned to the house at their father's mill in hopes that the sale of the hall and its property would raise enough money to cover their debts. ${ }^{278}$

These changes in domestic life, however, did not mean that the family accepted their fate. Rather, just as Catherine utilized her filial ties as a sister-in-law to garner support from the family network, the Reads' only son, Edmund, strove to perform his familial role as the future head of the business. This endeavor was not without complications due to Edmund's personal circumstances and the family's economic problems. A crucial aspect of the Reads' anxieties over money matters was the decision of how best to provide for their family, especially their twentyone-year-old son and brother, Edmund. Before 1834, Edmund did not appear to have any professional experience; for unspecified reasons he became most involved in the business after his father became seriously ill. Prior to this, Edmund claimed that his father only dictated "orders about the works, without telling [him] anything about what things were to be done or how they were to be done." ${ }^{279}$ Edmund's admission of his lack of experience in the family business is interesting as his position as the only son in the family would suggest that he should have been better prepared to assist in the family business.

\footnotetext{
${ }^{278}$ Edmund Read to William Wilson, The Mills, April 8, 1835, SSC, SSC 738, SCA.

${ }^{279}$ Edmund Read to William Wilson, The Mills, December 17, 1836, SSC 738, SCA.
} 
The aberrant nature of Joseph Reads' decision not to take a more active role in mentoring his son becomes even more curious considering that, as the only son of the eldest brother and nephew of his bachelor uncle, Edmund was the clear candidate to take over the business. As a twenty-one year old man in 1836, Edmund was the same age as his father and Uncle John when their father, Grandfather John, accepted them as partners in 1795 and $1798 .{ }^{280}$ Moreover, Uncle John specifically mentioned the importance of providing Edmund with more business experience as one of his reasons for retiring, which suggests that Edmund should have received extensive training since June 1831. It is quite possible that Edmund's status as the youngest child infantilized him in many ways, perhaps even contributing to his father's neglect of his professional education. ${ }^{281}$ Conversely, Joseph Read's financial difficulties may have distracted him from his fatherly obligation to promote his son's professional interests-- a task that John Tosh specifies as part of a father's duty to ensure his own current and his son's “future masculine standing." 282 This note is just one of many that suggest that Edmund did not measure up to the contemporary professional expectations of men his age.

Edmund's experience radically differed from the norm presented in secondary sources on men's professional training. These works suggested that many middle-class families actively prepared their sons for their professional careers by teaching them accounting and bookkeeping as part of their formative education and used their extended family and community networks to secure suitable apprenticeships. ${ }^{283}$ Typically young men started their apprenticeships under the tutelage of a member of the extended family or family friend around the age of fourteen and

\footnotetext{
${ }^{280}$ Wilson, Two Hundred Precious Metal Years, 57, 63.

${ }^{281}$ Ibid., 104.

282 Tosh, A Man's Place, 4, 115.

283 Hunt, 58-61. 89; Davidoff et al., The Family Story, 148.
} 
concluded their training when they were twenty or twenty-one. ${ }^{284}$ Consequently, apprenticeship marked the passage from boyhood into manhood and boys were expected to dedicate themselves seriously to their professional future and cast off "Childish amusements [for] matters of more importance." 285

Edmund appears to have failed to gain these skills by the time he was twenty and instead relied on Wilson's aid as a mentor to teach him bookkeeping and accounting. This ignorance was strange as according to the professional model described above Edmund was old enough to be nearly finished with his apprenticeship; yet his letters suggest that he had not yet mastered the skills he should have learned as a fourteen-year-old apprentice, such as how to take "monthly totals from the Ledger" and correctly balance totals recorded in the "ledger" but not the "counting-house day book." 286 There is not any evidence that Edmund served an apprenticeship and the correspondence suggests that even if he did complete one, it was inadequate. In December 1836, he claimed that he had "learnt more in the last few months than..."since [he] left school. ${ }^{287}$ It was, therefore, necessary that Edmund use these remedial lessons to familiarize himself with proper business practices so that he could assume his expected role in the family business. ${ }^{288}$ What is certain is that after his father became too ill to oversee the smelting works, Edmund enthusiastically seized the opportunity to take on the professional role previously unavailable to him.

\footnotetext{
${ }^{284}$ Hunt, 47; Morris, Men, Women, and Property in England, 148; Holland, “A Family Affair,” 30.

285 Hunt, 57.

${ }^{286}$ Edmund Read to William Wilson, The Mills, December 17, 1836, SSC 738, SCA; Edmund Read to William Wilson, The Mills, April 8, 1835, SSC, SSC 738, SCA; Edmund Read to William Wilson, The Mills, October 22, 1835, SSC, SSC 738, SCA; Edmund Read to William Wilson, The Mills, December 14, 1835, SSC, SSC 738, SCA. ${ }^{287}$ Edmund Read to William Wilson, The Mills, December 17, 1836, SSC 738, SCA.

${ }^{288}$ Edmund Read to William Wilson, The Mills, April 8, 1835, SSC, SSC 738, SCA; Edmund Read to William Wilson, The Mills, October 22, 1835, SSC, SSC 738, SCA.
} 
Edmund's letters illustrated his determination to learn how to fulfill his clerical duties and address his and his associate Mr. Wilde's mistakes. ${ }^{289}$ Mr. Wilde was a counting house clerk with a dubious employee history; he had once tried to establish his own rival smelting works with another Read \& Co. employee and was caught secretly selling Read \& Co.'s “overweight in Silverstock" to a rival company. ${ }^{290}$ It is little surprise, therefore, that Edmund strove to learn these skills quickly so that he could prove his effectiveness as an employee and surveil Wilde until the company could dispense with this duplicitous employee. ${ }^{291}$ The correspondence demonstrates Edmund's sense of obligation to protect his family's assets and his growing pride in carrying out his gendered, family role as a professional in the family business.

As Edmund adapted to his position, he became more and more confident in his abilities and the future of the company. By February 1837, he developed a misguided complacency regarding the company's debts based upon his underestimation of their reliance on the bank and overestimation of their ability to run the works solely from their customers' steady payments. Edmund recognized that the company's debts were problematic, particularly because they drained so much of the profits; yet, he envisioned a future in which the company could endure the bank's challenges by using a steady influx of cash to continue running the works and gradually repay their debts. ${ }^{292}$ For this reason, he indulged the hope that the steadiness of their customer's pay, the bank's tolerance, and more time would allow him to restore the company to prosperity.

\footnotetext{
${ }^{289}$ Edmund Read to William Wilson, The Mills, April 8, 1835, SSC, SSC 738, SCA; Edmund Read to William Wilson, The Mills, December 14, 1835, SSC, SSC 738, SCA.

${ }^{290}$ Wilson, Two Hundred Precious Metal Years, 75-6, 103; Edmund Read to William Wilson, November 17, 1836, SSC, SSC 738, SCA.

${ }^{291}$ Edmund Read to William Wilson, November 17, 1836, SSC, SSC 738, SCA; Edmund Read to William Wilson, The Mills, February 4, 1837, SSC, SSC 740, SCA.

${ }^{292}$ Edmund Read to William Wilson, The Mills, February 4, 1837, SSC, SSC 738, SCA.
} 
Unfortunately for Edmund, time had already run out. By early February 1837, the failure of another enterprise linked to Joseph's family network-- the Boothby foundry in Nottingham-compounded the financial strains caused by the Smiths' and Read \& Co.'s debts. ${ }^{293}$ Joseph Read had invested in the venture to support his eldest daughter's Mary Anne's husband, William Bacon Rawson. Rawson had died in 1829 and left enough money to cover his debts, but in January 1837 the Boothby's creditors looked to Joseph to fulfil the rest. ${ }^{294}$ This second failure of an enterprise linked to his affinal ties pushed Joseph Reads' financial troubles to a critical point. These circumstances squashed Edmund's plan of restoring a cooperative relationship with the bank.

By the middle of February 1837, the Reads' financial situation had become even worse: the bank was demanding payment and "refusing to honour any more cheques." Edmund's letter revealed that this placed the already floundering business in even more strain; they only had enough money to pay their workers a week's wages. ${ }^{295}$ Nevertheless, Edmund strategized ways to keep the works running as smoothly as possible by using the "small amounts" of cash on hand to pay some and deferring larger sums until they received more. ${ }^{296}$ Edmund's intrepid response to this problem demonstrates that, even in these tense times, he sought to use these experiences to learn how to be a proper businessman. The Reads' worsening circumstances compelled the entire family network to contemplate how best to address their financial problems.

The bank's refusal to provide financial support until their debts decreased forced the Reads to consider what they should do with the family business. Should they sell the works and its equipment in hopes of covering Joseph's debts? At the bottom of this question was how this

\footnotetext{
293 "Bankrupts," Sheffield Independent, February 4, 1837, BNA.

${ }^{294}$ Wilson, Two Hundred Precious Metal Years, 93.

${ }^{295}$ Edmund Read to William Wilson, The Mills, February 16, 1837, SSC, SSC, 738, SCA.

${ }^{296}$ Edmund Read to William Wilson, The Mills, February 20, 1837, SSC, SSC 738, SCA.
} 
decision would impact Edmund's future. On the one hand, it was Edmund's birthright to take over the company. On the other hand, was it right to give him the company in its current dwindled prospects? Moreover, with his lack of experience in running the works, Edmund needed someone who could continue to guide him in its management.

Uncle John was the clear candidate who should take up the business since his main reason for retiring in 1831 had been to protect the extended family's fortune. He was not, however, enthusiastic about the prospect. ${ }^{297}$ Family correspondence demonstrates that from March 1835 to February 1837, Uncle John dithered in carrying out his responsibilities as steward of his brother's financial problems; he postponed appointments to discuss money matters with his nephew, failed to relay messages about the company, and worried most about how his brother's debts would burden him. ${ }^{298}$ These actions illustrate Uncle John's disinterest and reluctance to lead the family business. Uncle John's plans for the future of the company amplified the family's doubts about his trustworthiness.

If he took charge of the family business, Uncle John intended to hire his second cousin, William Lucas, as manager. William Lucas was the grandson of Grandfather John's uncle, Samuel Lucas. Uncle John's decision to re-establish the Lucas family at Read \& Co. suggests that he favored the old connections within the family network as hiring Lucas would recreate the familial partnership that founded Read \& Co. Moreover, this was not a sudden decision; family correspondence proves that Uncle John had first recommended hiring Lucas when he was

\footnotetext{
${ }^{297}$ Wilson, Two Hundred Precious Metal Years, 104.

${ }^{298}$ Catherine Read to William Wilson, March 12, [Suggested 1835], SSC, SSC 738, SCA; William Wilson to John Read, Radford, May 16, 1836, SSC, SSC 764, SCA; Edmund Read to William Wilson, Attercliffe, January 12 , 1837, SSC, SSC 738, SCA; Edmund Read to William Wilson, The Mills, February 4, 1837, SSC, SSC 738, SCA.
} 
retiring. ${ }^{299}$ Bringing the Lucas family back to the company, however, was not an arrangement that everyone supported.

Edmund and his sisters rejected William Lucas as a viable professional ally due to "reports" that he "b[ore] no good character in more things than one." ${ }^{300}$ These accusations stemmed from Lucas' penchant for "running about the town all day and being at parties, clubs, etc. at night," suggesting that Lucas had a passion for drinking and gambling-- pastimes that the Reads as devout, teetotal Congregationalists would find unrespectable. ${ }^{301}$ It must have been difficult to stomach the idea of being personally and professionally connected to someone who would tarnish their reputation. Edmund substantiated his supposition by alluding to the fact that Lucas' exploits were apparently public enough that only his friends' intervention "ke[pt] [him] out of the gazette." For all of these reasons, Edmund seriously doubted that Lucas' bad habits would make him of "any good" to Read \& Co. ${ }^{302}$ Unfortunately, there are not any other letters, newspaper articles, or diaries that discuss or corroborate these claims about Lucas' poor personal character. Nevertheless, the family's concerns about Lucas' work ethic and morality were especially acute due to their doubts about Uncle John's dedication to Read \& Co. If both Uncle John and Lucas had more pressing concerns than the running of the smelting works, how could Read \& Co. survive?

In testament to his aversion to working with his disreputable third cousin, Edmund declared that if Lucas should be accepted into Read \& Co., he would set aside his own future aspirations and find work elsewhere. ${ }^{303}$ This ultimatum shows that Edmund valued moral

\footnotetext{
${ }^{299}$ John Read to Joseph Read, July 12, 1830, SSC, SSC 683, SCA.

${ }^{300}$ Edmund Read to William Wilson, The Mills, February 4, 1837, SSC, SSC 738, SCA.

${ }^{301}$ Ibid. Though the Reads were a part of a unique segment of Congregationalists who supported teetotalism before the 1870s, their abhorrence of "dancing, ambling, and card[playing]" was common amongst Congregationalists during this part of the nineteenth century. See Tudur Jones, 231, 292-3.

${ }^{302}$ Edmund Read to William Wilson, The Mills, February 4, 1837, SSC, SSC 738, SCA.

${ }^{303}$ Ibid.
} 
integrity over his professional pursuits-- a view seconded in Wilson's letters. This moral high ground could also have been bolstered-- if not based upon-- Edmund's unwillingness to accept competition, especially from a third cousin. Edmund's convictions on this subject created a palatable tension within the family correspondence. Edmund was suspicious of his uncle, fearing that Uncle John deliberately withheld his plans regarding Lucas from him because of his vehement rejection of them. His sister, Catherine, however, assumed that her uncle had dropped his suggestion out of respect for Edmund's wishes as the clear heir to Read \& Co. ${ }^{304}$ Regardless of Uncle John's motives and intentions, the company's future personnel was a subject of importance to everyone in the Reads' family network, including William Wilson.

Wilson's concerns about his in-laws professional and economic security compelled him to seek out ways to help them. This is hardly surprising considering his role as an advisor to Joseph and Edmund since 1834. Wilson's own prosperity and sentimental concern for the Reads inspired him to offer to join Read \& Co. as a partner in the business in mid-February 1837 . When considering working with his in-laws, Wilson did not jump into the business blindly. Unlike his father-in-law, Wilson set clear boundaries as to what he was willing to do and was open about his limitations. Though he was "prepared to manage it and take Edmund under his wing," he clearly stipulated that he would only do so as long as he could determine that the business was stable, profitable, and would not sink him. ${ }^{305}$ Wilson was wary of his in-law's reaction to this suggestion, but he need not have been. The majority of the family were overjoyed by this

\footnotetext{
${ }^{304}$ Edmund Read to William Wilson, February 4, 1837, SSC, SSC 738, SCA; Edmund Read to William Wilson, Attercliffe, January 12, 1837, SSC, SSC 738, SCA; Catherine Read to William Wilson, The Mills, [Suggested February 20, 1837], SSC, SSC 738, SCA.

305 Wilson, Two Hundred Precious Metal Years, 102.
} 
proposition. ${ }^{306}$ What his father-in-law, Joseph, felt about the subject was most difficult to determine.

Unfortunately, there are not any letters from Joseph that provide his own words on the subject. There were, however, allusions to their father's opinion in some of his children's correspondence. Catherine confided to her brother-in-law that her father did not seem "at all sanguine" about his offer but reasoned that as he had "not object[ed,] [she] hope[d] he [was] pleased." ${ }^{307}$ Edmund's account described a much more positive reaction from their father. The day after Catherine's letter, he claimed that their father "quite approve[d] of the plan, at least as far as he ha[d] thought about it.” Perhaps Joseph's family's enthusiasm had made him susceptible to the idea; or, Edmund may have misinterpreted his father's receptiveness due to his own approbation of it. Unlike his brother, Uncle John enthusiastically supported Wilson's offer.

Uncle John welcomed Wilson's proposal to become a partner in the business, promising to "do everything in [his] power to forward it." This answer corroborates other evidence illustrating Uncle John's reluctance to take over Read \& Co. Now that there was a clearer alternative, Edmund and his family did not mind Uncle John's half-heartedness towards the business. In fact, they found his attitude on the matter "very satisfactory." 308 The family's concerns regarding Uncle John's dithering attention to Read \& Co., his plans to hire Lucas, and their mounting financial troubles likely made Wilson's offer even more desirable. Therefore, various members of the family tried to persuade Wilson to become a partner at Read \& Co.

\footnotetext{
${ }^{306}$ Catherine Read to William Wilson, The Mills, [Suggested February 20, 1837], SSC, SSC 738, SCA; Emily Read to Eliza Wilson, in Elizabeth Read to William Wilson, The Mills, February 17, 1837, SSC, SSC 744, SCA; Mary Anne Rawson to William Wilson, ND, [Suggested February 1837], SSC, SSC 749, SCA; Elizabeth Read to William Wilson, The Mills, February 17, 1837, SSC, SSC 744, SCA.

${ }^{307}$ Catherine Read to William Wilson, The Mills, [Suggested February 20, 1837], SSC, SSC 738, SCA.

${ }^{308}$ Edmund Read to William Wilson, The Mills, February 21, 1837, SSC, SSC 738, SCA; Catherine Read to Eliza Wilson, in Edmund Read to William Wilson, The Mills, February 21, 1837, SSC, SSC 738, SCA.
} 
As a man, not to mention the only son, Edmund's familial role was to earn money to support his family. Therefore, Edmund's letters focused on his awareness of business matters to encourage his brother-in-law's interest in Read \& Co. by assuring Wilson that they had "done more business within the last fortnight, than in any month last year [and] might increase... to any extent... if [they] had the means." ${ }^{\prime 309}$ Additionally, the fact that Edmund and Wilson had engaged in extensive correspondence on the topic since 1835 made it natural for them to continue collaborating on professional matters. Edmund's conviction to uphold his professional responsibilities were particularly pressing due to his family circumstances: he would have to provide for his two spinster sisters and to a lesser extent his widowed sister, Mary Anne, following his father's death.

Catherine and her mother, Elizabeth Read, practiced their gendered, feminine roles as advocates and supporters in the family network. Like Catherine's intervention in March of 1835, Catherine and Elizabeth's letters from 1837 demonstrate that the female family members utilized their "natural" role as caretakers and their affectionate connections to the members of their family network to shore up resources and aid. Catherine and Elizabeth therefore drew upon filial duty and emotional appeals to compel Wilson to fulfill his role within their family network.

Catherine's letters demonstrate that she used her influence to support her male family members' interests. She endorsed her brother Edmund by lauding his dedication and "attentive[ness] [to] business" while acknowledging his limitations. Though Edmund had a hardworking spirit, there were currently too many "difficulties [for him to be] managing a business alone." ${ }^{310}$ If Wilson would guide and mentor Edmund, however, these obstacles could easily be surmounted without endangering the business. Catherine's purpose in writing was

\footnotetext{
${ }^{309}$ Edmund Read to William Wilson, The Mills, February 16, 1837, SSC, SSC 738, SCA.

${ }^{310}$ Catherine Read to William Wilson, The Mills, [Suggested February 20, 1837], SSC, SSC 738, SCA.
} 
therefore to convince Wilson that Edmund deserved his attention and that his help could do her family much good, as Edmund's professional career and the family's livelihood depended on Wilson taking responsibility for his in-law's business.

Catherine was particularly well-situated to advocate on her family's behalf because she had formed a friendship with Wilson during extended visits with his family to help her frail sister, Eliza Wilson, raise her rapidly growing family. This relationship provided opportunities for her to remind Wilson of the impact that her family's downfall would have on his nuclear family's wellbeing, as they would likely be unable to visit in the present circumstances-- even if someone should become ill. ${ }^{311}$ Catherine described not only how the family's financial strains would prohibit travel but also its impact on the family's ability to serve as a support system to the Wilsons. Catherine accordingly reminded Wilson of his ties to the Reads and urged him decisively to commit to joining as partner. Catherine's letter offers evidence of the rules of reciprocity, according to which her services as a domestic aid to Wilson's nuclear family entitled her to ask for his support.

Wilson's mother-in-law, Elizabeth Read, also used her filial relationship and emotional ties to rally Wilson into action. Like Catherine, she wrote on Edmund's behalf, informing Wilson of her son's recognition of "how unequal he [was] at the present to be the first person in the concern." She assured Wilson, nevertheless, of her faith in him as a son-in-law, expressing her confidence that his "presence" would supply Edmund with moral "good influence" as well as "useful knowledge" and "business-like habits." 312 This flattery served a dual purpose: it recognized Wilson's worth by expressing his desirability as a mentor while simultaneously using

\footnotetext{
${ }^{311}$ Catherine Read to William Wilson, The Mills, [Suggested February 20, 1837], SSC, SSC 738.

312 Elizabeth Read to William Wilson, The Mills, February 17, 1837, SSC, SSC 744.
} 
her confidence and esteem towards him to coerce him into fulfilling his obligations to the family network.

Despite the family's strategizing and economizing, their financial state worsened when Joseph Read declared bankruptcy in March 1837. Now in the boiling point of their financial crisis, the bank's directors demanded that the Reads take more serious action; the bank blamed Uncle John for the protracted nature of his brother's financial issues, accused him of not taking the debts seriously, demanded that someone else take over management of Joseph's financial affairs, and enthusiastically accepted Edmund's suggestion that Wilson supplant him. Edmund desperately seized upon this opportunity to appease the bank, beseeching Wilson to vouch that "steps were being taken to reduce the account," which he assured him was the case-- though their efforts seemed "very little in comparison to the largeness of the a/c." ${ }^{313}$ This shift in allegiance demonstrates that the Reads used their family networks strategically to provide the best resources possible, substituting Uncle John with William Wilson when it best suited their interests. The Reads' decision placed them in a potentially awkward position; they needed to appease the bank and avoid insulting Uncle John with the news of his diminished role in the family network. The family's hesitation to communicate this news to him for days afterwards attests to the delicacy of this task. ${ }^{314}$ Unfortunately, Wilson would not prove any more enthusiastic about the role than Uncle John.

After communicating with the bank, Wilson appeared to doubt the wisdom of becoming a partner in the business and asked to review the accounts. ${ }^{315}$ Though there are not any direct statements that explain exactly what led him to reconsider, sometime between March 2nd and

\footnotetext{
${ }^{313}$ Edmund Read to William Wilson, March 2, 1837, SSC, SSC 738, SCA.

${ }^{314}$ Edmund Read to William Wilson, March 6, 1837, SSC, SSC 738, SCA. David Warren Sabean also makes this argument in his seminal work, Kinship in Neckerhaussen.

${ }^{315}$ Edmund Read to William Wilson, March 6, 1837, SSC, SSC 738, SCA.
} 
9th, Wilson rescinded his offer based on his "conviction that [he] ought not to do any thing... likely to destroy the prosperity and comfort of [his nuclear] family." ${ }^{316}$ At this point, he reasoned that the best course of action for both himself and his in-laws would be to buy Read \& Co. and create a "bond to support" them. ${ }^{317}$ This plan would allow him to continue mentoring Edmund without placing himself at financial risk for the company's past debts. ${ }^{318}$ Due to her intermediate position within both families, Wilson relied on Catherine to negotiate on his behalf by explaining the benefits and necessity of such a course of action. Wilson believed that it was in everyone's best interest to "sell" the company in order to "provide... provision for the family." 319 For these reasons, Wilson asserted that this course of action was best for the entire family network.

Secondary literature verifies the soundness of Wilson's advice by confirming that most sons served their apprenticeships outside of their nuclear homes to promote their attainment of "self-sufficiency" and avoid "complacency and dependence." ${ }^{320}$ Edmund's father's decision not to send him away for an apprenticeship attests to these concerns. Wilson's suggestion that Edmund secure a position within another company therefore served two purposes. It provided Edmund with an environment in which he could gain the necessary work experience and ensured him a secure position if Read \& Co. should fail. Edmund's age should also be taken into consideration as by this point he should have already established a secure professional position according to the standard professional life cycle. ${ }^{321}$ Therefore, Edmund's best chances of securing his professional future relied on him finding a situation which could provide him with a morally upright, business savvy mentor in a stable enterprise. This scheme also suited Wilson's

\footnotetext{
316 William Wilson to Catherine Read, Radford, March 9, 1837, SSC, SSC 747, SCA.

${ }^{317}$ Wilson, Two Hundred Precious Metal Years, 103.

318 Ibid.

${ }^{319}$ William Wilson to Catherine Read, Radford, March 9, 1837, SSC, SSC 747, SCA.

${ }^{320}$ Barker, 33; Grassby, 281-2.

${ }^{321}$ Morris, Men, Women, and Property in England, 148.
} 
self-interest by allowing him to fulfill his moral obligation to promote his brother-in-law's professional future without requiring him to take the same financial risks as becoming a partner in a business he could not control. ${ }^{322}$ This type of imprudent action was just what Joseph Read had done in 1816 - to catastrophic result, leading one to wonder how much of Wilson's framing of this matter used Joseph's own example to prove the soundness of his new proposal.

Though hindsight makes it easy to condemn Joseph's decision to join Smith's foundry as partner in 1816, he could not have predicted that the enterprise would deteriorate after the Napoleonic Wars, especially when Britain's global interests had expanded in scale. Instead, it likely seemed like a lucrative business opportunity which would allow him to support his affinal ties while increasing his wealth. When it became clear that business was unstable and Uncle John urged Joseph to remove himself from the concern, Joseph may have felt honor-bound to support his in-laws. Wilson, however, had the benefit of knowing beforehand that joining Read \& Co. as a partner was a risky venture. Under these circumstances, Wilson was able to distance himself from familial obligations by pointing out the dangerous impact that this would have on his nuclear family's well-being. When placed in the context of the historiography on masculinity and the public sphere, this decision suggests that Wilson sought to protect his masculine image as a protector of dependents; Wilson, therefore, prioritized his public image and his personal reputation over his obligations to his in-laws. These exchanges also demonstrate that family networks and nuclear families coexisted: individuals simultaneously attempted to draw upon family networks for material support and administrative aid or refused to fulfill these obligations due to conflicts with their duties to the nuclear family.

${ }^{322}$ William Wilson to Catherine Read, Radford, March 9, 1837, SSC, SSC 747. 
In contrast, Joseph and Edmund's reliance on Wilson's aid undermined their public, professional status. This supposition is supported by the marked changes in Joseph's participation in philanthropy after the Smith's bankruptcy in 1834. From 1821-1833, Joseph served as chairman and held offices in the local anti-slavery movement, Lancastrian Boys' and Girls' Schools, Sheffield and Attercliffe Auxiliary Missionary Society, and Sunday School Union. ${ }^{323}$ It also seems plausible that Edmund's late professional development and financial instability stifled his engagement in civil society, as demonstrated by his lack of involvement in the same causes his father and sisters supported. Regardless of his good reasons, the Reads must have found Wilson's opinions unfavorable or disappointing. Due to her intermediate position within both families, Catherine shouldered the burden of communicating Wilson's reasons to her family and sharing their responses with him.

As a networker, Catherine collaborated with her family to establish a beneficial plan for all parties. In this instance, she used her familiarity with the family's economic problems, hardships the company faced, and her family's feelings about the situation to advise Wilson about the chief obstacles to his plan. For instance, she warned him that her father and Uncle John may believe that the company was more "prosperous" than he did and would therefore "expect" him to pay more than he was willing. ${ }^{324}$ Her hint prepared Wilson for this eventuality, allowing him to avoid unintentionally insulting her family or being pressured into giving more than he

\footnotetext{
323 “Lancasterian Boys' School," Sheffield Independent, June 30, 1821, BNA; "Boys' Lancasterian School," Sheffield Independent, June 29, 1822, BNA; "Abolition of Negro Slavery in the Colonies," Sheffield Independent, April 26, 1823, BNA; "Christian Missions," Sheffield Independent, May 1, 1824, BNA; "Abolition of Slavery," Sheffield Independent, August 14, 1824, BNA; "Girls' Lancasterian School of Industry," Sheffield Independent, March 17, 1827, BNA; "Girls' Lancasterian School," Sheffield Independent, March 15, 1828, BNA; "Sheffield Sunday School Union," Sheffield Independent, May 31, 1828, BNA; "Boys' Lancasterian School," Sheffield Independent, June 21, 1828, BNA; “Anti-Slavery Society,” Sheffield Independent, July 27, 1833, BNA. ${ }^{324}$ Catherine Read to William Wilson, March 10, 1837, SSC, SSC 738, SCA.
} 
thought the business was worth. This letter also addressed another hinderance to his plan: her father's feelings about Wilson's proposal.

Despite his reliance on Wilson's advice and judgement, Joseph Read could not bring himself to place Edmund's future completely in his son-in-law's hands. Ironically, out of all the male family members, Edmund was the least disturbed by Wilson's scheme because he had faith in Wilson's good intentions. Joseph Read, however, refused to risk it; instead, he advocated selling some of the company's properties and shares so that he could appease the bank by reducing their debts and continue running the smelting works. ${ }^{325}$ Catherine's letters show, however, that the family was not united in this plan.

Catherine and her female family members favored Wilson's plan because it offered greater economic security. As Catherine explained, "two or three... wretched... years [of] anxiety and care" about money induced her to embrace the benefits of a reduced income so long as it was "sufficient to enable Papa and Mama...every comfort." Moreover, Catherine doubted the utility of her father's plan because her father often struggled with decisive action. For this reason, she advised that though they should "kindly" acknowledge his "opinion" and "feelings", they could not let her father's resistance towards "any great change" stop them from pursuing an alternative path-- or "nothing will ever be done." 326

Catherine's statement may seem harsh, but it was a pragmatic approach necessitated by the family's dire circumstances and her father and uncle's hesitancy to take action. It is clear that Catherine was not a passive contributor to the family network-- she weighed in on these serious matters and challenged her father's proposed course of action. Nevertheless, it seems that even Catherine's aid and support of the scheme could not fully shake the family's concerns about its

\footnotetext{
${ }^{325}$ Catherine Read to William Wilson, March 10, 1837, SSC, SSC 738, SCA.

326 Ibid.
} 
impact on their future. When Wilson introduced a new proposal, which he believed addressed the weak points of the two earlier ones, he again turned to his spinster sister-in-law, Catherine, as his advisor, negotiator, and supporter.

Wilson wrote to Catherine on March $25^{\text {th }}$ to share his latest proposal to form a joint partnership with Uncle John and asked her whether or not this would be "desirable." 327 This decision merits further analysis as it shows that Wilson chose to write this letter to his spinster sister-in-law rather than having his wife, their sister Eliza, address her family or directly communicating with either Edmund or Uncle John-- the two active professionals in the family. Though it may seem to have been more natural for his wife to have played this role, Eliza was not a useful ally because her position near Nottingham kept her detached from her natal family and their feelings and wishes. Edmund would also have been a poor candidate as his enthusiasm for working with Wilson would likely have caused him to overexaggerate his father's receptiveness to the proposal, making him an inaccurate source on the family's opinion. Lastly, it would not have been prudent to write to Uncle John personally because Wilson vacillated over whether or not he should form the partnership. Therefore, Catherine represented the best choice because she could use her understanding of the situation to determine whether or not the plan would work for all parties involved and, if she agreed with it, deploy her influence in Sheffield to negotiate on Wilson's behalf. The exchange of these letters between Wilson and Catherine demonstrates that Wilson valued Catherine's opinion, trusted her judgement, and found her capable as an emissary.

Wilson believed that a joint partnership would protect both his and the Reads' interests simultaneously by allowing him to safeguard his own fortune and the Reads' respectability and

${ }^{327}$ William Wilson to Catherine Read, Radford, March 25, 1837, SSC, SSC 764, SCA. 
connection to the business' future and profits. ${ }^{328}$ This affiliation would allow Wilson to help Uncle John oversee the company, ameliorating Wilson's concerns about financial responsibility and Joseph's family's anxieties about Uncle John's disinterest in the business. ${ }^{329}$ Wilson was right to believe that this scheme addressed all of the family's concerns for when Catherine shared this proposal with her nuclear family, it was joyously accepted. Edmund lauded it as the best possible situation; his uncle would maintain control over the business while Wilson helped him learn necessary skills and, perhaps most importantly, Wilson's "presence would inevitably... cause Willm. Lucas' absence.” More spectacularly, he claimed that even his usually morose "father... seemed to like [this plan] better than the others." ${ }^{330}$ Edmund and his natal family also favored Wilson's plans to become a partner because they assumed that this meant he and his family would move to Sheffield. ${ }^{331}$ Wilson's sentiments on what must be done to protect Edmund's future with or without his intervention in the company, however, suggest that this was not a part of his plans.

Regardless of whether they formed a joint-partnership, Wilson insisted that, for Edmund to reach his professional potential, he needed to work with a professional mentor who would shepherd him in practices of a proper businessman. Wilson's skepticism about the lucrativeness of Edmund remaining at Read \& Co. suggests that he did not intend to move to Sheffield and that he had concerns about Edmund training under Uncle John or William Lucas. Uncle John's distraction with other business interests and Lucas' unrespectable moral and professional behavior made neither of the two ideal candidates. For these reasons, Wilson urged that

\footnotetext{
${ }^{328}$ William Wilson to Catherine Read, Radford, March 25, 1837, SSC, SSC 764, SCA.

${ }^{329}$ William Wilson to Catherine Read, Radford, March 25, 1837, SSC, SSC 764, SCA; Edmund Read to William Wilson, The Mills, March 25, 1837, SSC, SSC 738, SCA.

${ }^{330}$ Edmund Read to William Wilson, The Mills, March 25, 1837, SSC, SSC 738, SCA.

${ }^{331}$ Elizabeth Read to William Wilson, The Mills, February 17, 1837, SSC, SSC 744, SCA.
} 
Edmund's mentorship have a "a beneficial influence [on his] moral and religious" growth. ${ }^{332}$

Even though Wilson did not name him specifically, the family correspondence suggests that he was most likely referring to Lucas' unsuitableness for the role.

To men like Wilson, moral and religious concerns were neither trifling matters nor disconnected subjects from business and professional goals: they were superior to all else "because the mischief in connection with them might be irremediable." 333 The family's concerns about Lucas' effectiveness as a professional model were compounded by their anxiety that Edmund might fall prey to Lucas' immoral lifestyle. Though Edmund was an upstanding young man who was free from "outward sin", his mother, Elizabeth, worried about the "unsafe state of his precious soul [because] he ha[d] yet given no satisfactory evidence that he ha[d] passed from death unto life." 334 As a devout evangelical, Congregationalist, Edmund's mother's religious beliefs stressed the importance of a deep, inwardly directed personal faith that sought personal betterment by asking for forgiveness for one's sins and striving to live a devout, Christian spiritual and personal life. ${ }^{335}$ For these reasons, she felt uneasy and alarmed at the idea that Edmund had not accepted Christ as his savior.

Unlike his mother and sisters' letters, Edmunds correspondence never directly addressed his faith. Mary Anne and Catherine's letters, in particular, often condemned avarice and advocated submissive acceptance of God's will. ${ }^{336}$ For example, when discussing her father's debts, Mary Anne confessed that "only [her beliefs about the] shortness of life... and that all

\footnotetext{
${ }^{332}$ William Wilson to Catherine Read, Radford, March 25, 1837, SSC, SSC 764, SCA.

333 Ibid.

${ }^{334}$ Elizabeth Read's Diary, December 22, 1844, MAR, MD 6042, SCA; Elizabeth Read's Diary, August 1, 1847, MAR, MD 6042, SCA; Elizabeth Read to Edmund Read, February 23, 1830, Wincobank, MAR, MD 5697, SCA. ${ }^{335}$ Standish, 89; Hall, “The Sweet Delights of Home," 60-1; Brunner, 79; Ceri Jones, 100.

${ }^{336}$ Mary Anne Rawson to John Read, [Suggested 1831], MAR, MD 5692, SCA; Catherine Read to Mary Anne Rawson, December 23, [1831], Torquay, MAR, MD 5692, SCA; Catherine Read to Mary Anne Rawson, [1831], MAR, MD 5692, SCA.
} 
these sorrow[s] [were] but necessary discipline inflicted by a wise and kind Heavenly Father to prepare us for that blessed state [offered her] any degree of cheerfulness or composure." ${ }^{337}$ This disparity within the family correspondence supports his mother's claims that he was not a devout Christian. It also explains why his resistance to devoting himself to his faith made his family suppose he would be vulnerable to the temptations of Lucas' worldly lifestyle: contemporary opinion asserted that one immoral behavior led to the cultivation of others. ${ }^{338}$ The family network's anxiety about this subject demonstrates that middle-class men's work had high professional and moral stakes that directly impacted their future economic and financial success and personal or spiritual happiness. Unfortunately, this perfect scheme was not to become a reality.

Despite the family's hope and optimism concerning Wilson's proposed joint-partnership with Uncle John, by early April the plan had fallen through. It seems that Wilson's concerns about the profitability of the company made him unwilling to enter into any venture except a joint-partnership. Though Edmund remained unrelentingly optimistic about the company's potential, he expressed his fear that his uncle's leadership would weaken it and his conviction that, in this case, it would be best to find work elsewhere. ${ }^{339}$ Despite his threats to leave, Edmund's emotional ties to the family company and his convictions about its rich potential deterred him from any drastic actions, no matter how frustrating the new regime might be.

Edmund's disappointment about Uncle John's leadership proved to be twofold; not only would Wilson not be joining the business, but he would also be forced to work with two men he distrusted: Wilde as the company's clerk and Lucas as “manager" of the works. Uncle John's

\footnotetext{
${ }^{337}$ Mary Anne Rawson to John Read, The Mills, [May or June 1837], SSC, SSC 765, SCA.

338 Hunt, 49-50.

${ }^{339}$ Edmund Read to William Wilson, The Mills, April 6, 1837, SSC, SSC 738, SCA.
} 
decision to hire Lucas over the protests of Edmund and his family suggests that Uncle John held conflicting familial obligations to both the Reads and the Lucases. It seems that Uncle John felt a strong conviction that he must find a position for Lucas in the family business without alienating his brother's family. Therefore, he appointed Lucas as manager (a position where he would "not meddle with the books... at least not much") to fulfill his duty to both parties. As sensible as this "plan" seemed, Edmund asserted that it could never work because the functions of "counting house and yard [were so] intimately connected that no arrangement could be made ... without a thorough understanding of the transactions in the other." ${ }^{340}$ The clash between Edmund and Lucas demonstrates Uncle John's difficulty in trying to please two conflicting branches of one's family network. ${ }^{341}$ Uncle John's desire to maintain this connection and his brother's family's indifference suggests that Uncle John remained more strongly tethered to his father's maternal kin; perhaps this circumstance resulted from his bachelor status which left him without competing obligations to affinal ties. Whatever feelings of obligation he held for the Lucases and the Reads, Uncle John remained unenthusiastic about his responsibilities as the new head of the business.

Despite the fact that he had already made plans regarding Read \& Co., in May 1837, Uncle John experienced cold feet. It is clear from his letters that he resented having to give up his own interests to oversee his brother's affairs. For this reason, he wrote to Wilson explaining that he would only seize control if no one else would to protect his investment and his father's legacy and bid Wilson to tell him about his intentions for Read \& Co. Even though Uncle John

\footnotetext{
${ }^{340}$ Edmund Read to William Wilson, The Mills, April 6, 1837, SSC, SSC 738, SCA.

${ }^{341}$ Uncle John's attachment to the Lucases is corroborated by other pieces of family correspondence that suggest Uncle John and his spinster sister, Aunt Anne, maintained ties with the Lucases. See Emily Read to Miss [Anne] Read, The Mills, August 8, 1835, MAR, MD 5696, SCA; Catherine Read to Anne Read, Torquay, May 3 , [Suggested 1841-2], MAR, MD 5694, SCA.
} 
did not want the responsibility of serving as head of the company, he still wished to protect the family's future interests; namely his nephew's connection to the company as a future partner. ${ }^{342}$ Wilson balked at Uncle John's insinuation that he had ulterior motives, reminding Uncle John that he had only offered to buy the company because bonds of obligation compelled him to help his in-laws, especially Edmund. ${ }^{343}$ Moreover, he reminded Uncle John that he had already withdrawn his offer to purchase the business, implying that Uncle John had previously rejected the joint-partnership. Even if he refused to take any unnecessary personal risks, Wilson was still willing to offer counsel, particularly regarding Edmund's future.

Regardless of past offers to purchase the business, Wilson argued that Uncle John's questions about whether he would accept Edmund as a partner were unreasonable due to Edmund's present state of unpreparedness. Wilson remained convinced that the only way to secure Edmund's future was to place him in a position that would teach him "close attention to business, good habits \& correct notions" and "the importance of establishing a character as a man \& a tradesman." Uncle John's distraction from the business and Lucas' poor work habits made it unlikely that Edmund could acquire these qualities at Read \& Co. Wilson insisted that Edmund's future prospects depended on his abilities as a professional because Read \& Co.'s precarious state made it unlikely that his family could ensure him a position in the only place he would currently be guaranteed promotions-- his family's firm. This was a serious consideration as Wilson himself noted that "neither [he] nor... any prudent man [could] be expected... to receive an unformed man as a future partner." 344 Wilson and Uncle John's exchange thus illuminates the connection between men's familial, masculine roles and their professional

\footnotetext{
${ }^{342}$ John Read to William Wilson, Trafalgar Hotel and Spring Gardens, May 12, 1837, SSC, SSC 763, SCA.

${ }^{343}$ William Wilson to John Read, Radford, May 13, 1837, SSC, SSC 763, SCA.

${ }^{344}$ Ibid.
} 
reputations by demonstrating the importance of professional education and experience in safeguarding a man's future business prospects.

Though it is unclear whether it was written before or after Uncle John wrote to Wilson in May, a letter from Mary Anne to Uncle John demonstrates her consciousness of the family's hardships and use of her filial influence to counsel Uncle John against purchasing Read \& Co. Even in cases where male family members did not seek out their female family member's opinion, women in the family clearly utilized their affective, filial ties to offer advice and suggest caution. This point illustrates once more that middle-class women were not only conscious of their family's financial and professional hardships - they actively engaged in the resolution of these problems.

Like her mother and sister's letters to William Wilson, Mary Anne's letter to Uncle John played upon notions of filial duty and affection by framing her advice as the worries of a caring, concerned niece. Mary Anne's fears that Uncle John was “involving [himself] in [unnecessary] risk or anxiety" out of a misguided sense of obligation to her family enabled her to comment on the family's current setbacks and present alternative solutions. Mary Anne's allusions to the company's financial difficulties in her subtle reference to the "very grievous and disappointing result of the stock-taking" established her awareness of these problems and vindicated her ability to advise Uncle John. ${ }^{345}$ In addition to this comment, one of Edmund's letters directly acknowledged his sisters' awareness and participation in “conversations" about the business's financial problems, which offers further evidence that women were not excluded from discussions about the family business. ${ }^{346}$ Even if her knowledge came entirely from male family member's accounts, Mary Anne's reference to the family business' concerns challenges the

\footnotetext{
${ }^{345}$ Mary Anne to John Read, The Mills, [May or June 1837], SSC, SSC 765, SCA.

${ }^{346}$ Edmund Read to William Wilson, The Mills, February 16, 1837, SSC, SSC 740, SCA.
} 
separation of spheres ideology and demonstrates that female family members had influence within the family network.

Mary Anne not only understood the seriousness of their family's financial situation, she felt compelled to write to her uncle to express her anxieties. Mary Anne's ability to do so shows that women's association with domesticity did not bar her from matters of business; rather, her gendered, familial position empowered her to act on behalf of the family network. After proving that she was aware of the company's current problems, Mary Anne used modesty and familial solicitude to ask Uncle John to reconsider. Though she did not have any "understanding of business affairs generally," she felt compelled to "ask... whither it would not be better to dispose of [the company since]... the business... seem[ed] such a poor concern." 347 This calculated statement shows that Mary Anne was not overstepping her boundaries by broaching this topic: she was fulfilling her duty as a caretaker and agent of the family network to seek its best interests.

Regardless of her humility concerning her business acumen, Mary Anne did not have any qualms about advising someone who held more traditional power and seniority within the family network. She clearly placed enough confidence in her own understanding of what was best for the family to try to persuade Uncle John to reconsider his plans. She assured her uncle that her family would be far happier living on "a small annual sum" than making him "risk [his] property." Though this notion may appear self-sacrificing, Mary Anne admitted there were "selfish" motives behind it: she knew that he would "never [allow] any of the family [to] want [so long as he had the means to protect them], but if [he] should [also] get involved there would

\footnotetext{
${ }^{347}$ Mary Anne to John Read, The Mills, [May or June 1837], SSC, SSC 765, SCA.
} 
be no [remaining] resource." ${ }^{348}$ This comment illustrates that she was not just driven by moral or emotional reasons, but was endorsing this course as a practical, defensive measure.

Mary Anne was not writing to him on a whim. Her argument, like Catherine's earlier statement to Wilson, reflected her experiences throughout her family's financial difficulties. The uncertainties of the last few years had convinced her that it would be far better to live under a strict, yet sure regime of economies than spend "another winter in the anxiety [of] the last-[when] sometimes [there was] scarcely a sovereign in the house or the counting house." ${ }^{349}$ As such, her status as a domestic authority within the family network endowed her with the right and responsibility to advocate for its welfare.

After the exchange of letters between Wilson, Uncle John, and Mary Anne, Wilson did not renew his offer to assist Read \& Co. and it seems that despite Mary Anne's advice, Uncle John felt compelled to take over the business as he did "not see how it" could "be avoided." 350 Regardless of the higher goals behind his self-sacrifice, Uncle John continued to be lackluster in his supervision of the works because of his preoccupation with other ventures. ${ }^{351}$ This behavior confirmed the family's fears about Uncle John's unwillingness to concentrate on Read \& Co. Joseph Read's death a month later in July 1837 compounded the family's emotional and financial trauma by making Uncle John responsible for repaying his brother's debts after Joseph's property in Attercliffe failed to sell at auction. This left Uncle John with little capital to reinvest in the business. ${ }^{352}$ Ergo, as was the pattern since February 1837, financial limitations made it impossible for Read \& Co. to advance itself into "profitability." 353

\footnotetext{
${ }^{348}$ Mary Anne to John Read, The Mills, [May or June 1837], SSC, SSC 765, SCA.

${ }^{349}$ Ibid.

${ }^{350}$ John Read to William Wilson, the Mills, June 5, 1837, SSC, SSC 763, SCA.

${ }^{351}$ Wilson, Two Hundred Precious Metal Years, 105.

${ }^{352}$ Ibid., 106.

${ }^{353}$ Ibid.
} 


\section{Conclusion}

As this chapter has shown, family ties bound men and women together-- for richer or poorer. Despite prior assumptions that the extended family lost influence during the modern period, new works of scholarship show that family networks continued to play a crucial role in the social, professional, and economic lives of the industrial middle class. It was specifically through these structures that the emerging middle class pooled together resources necessary to establish family businesses like capital, influence, and property. What's more, respectable work and dedication to one's business increasingly became a cultural calling card of middle-class identity, making the fact that family networks played an integral role in the creation and sustainment of these ventures doubly important. Though past studies assumed that only male family members performed roles to protect the family business, current scholarship challenges this view. Within these family networks, individuals collaborated in gender specific roles to further the family's interests and respond to crises. Using the Reads' examples as a vantage point on nineteenth-century family networks illuminates four themes: reciprocity, professionalization and the family business, family strategy, and bankruptcy.

Family networks created an alliance that protected the group's interests. In order to ensure that the ties of affection and obligation necessary to secure these interests remained intact, family members engaged in acts of reciprocity, such as writing letters, paying extended visits or social calls, and exchanging gifts. Female family members undertook particular responsibility for utilizing acts of reciprocity to protect and reinforce the stability of the family network. Their domestic roles within the family network, therefore, included securing and protecting the interests of the family business. Catherine Read, Elizabeth Read, and Mary Anne Rawson's letters to their male family members reveal how they utilized their gendered familial roles and 
practices of reciprocity to promote the nuclear family's needs and the family network's interests. In each example shown, these women used their gendered, kin status as an "affectionate" "sister[-in-law]," "mother[-in-law]" or "niece" to reinforce their arguments and compel male family members to uphold their responsibilities to the kinship network through their requests for favors or offering of advice. Conversely, the male family member's professional roles directly influenced their private, familial roles.

If women utilized familial roles to engage in public matters like family business, men's professional identities directly informed their roles as husbands, fathers, brothers, and sons. As demonstrated through Joseph, Uncle John, Edmund, and Wilson's examples, a professional identity served as a crucial part of their masculine family roles. Each of these men's experiences reveals the centrality of professional competence in protecting or endangering their future prospects. Edmund's example in particular shows the importance of professional education and training to a man's professional career and public image. In making decisions about the family, men and women came together to support and denounce alternative strategies based on the competence of their kin.

The Reads' family network evidences that family strategy did not always equate family success. The serious financial troubles the Reads found themselves in were the result of poor business choices made to support their affinal ties: Joseph's decision to invest money in his father-in-law's business, Smiths' Chesterfield Works and his son-in-law, William Bacon Rawson's, venture, Boothby's foundry in Nottingham. Alternatively, family ties could be a source of strength which allowed individuals to shore up resources, such as Grandfather John and his maternal uncle, Samuel Lucas' partnership that established Read \& Co. Likewise, families did not always agree on the best solutions: whether to sell the business or continue it, 
what roles each individual should play, and how to provide the entire family networks' best interest. As this chapter has also shown, family members also disagreed on who this network encompassed and what ties should be protected-old family ties such as the Lucases or new affinal ties like the Wilsons. In each of these questions, the answer depended upon how each option would advance their goals or address their current financial setbacks.

The Reads' examples offer valuable insights into the economic and professional world by demonstrating the benefits and dangers of the world of business. Though scholarship tends to focus on examples of success, the Reads' experiences of the vagaries between success, failure, and outright survival show a more common picture of the challenges of nineteenth-century business. Looking at the family business in its contemporary setting reveals the precarious nature of business ventures and the ways in which bankruptcy targeted the rising industrial and commercial elite. The family's experiences present an opportunity to readdress our understandings of debt, familial obligation, and business methods. The Reads' experiences illuminate how family networks used practices like reciprocity and family strategy to respond to the challenges posed by nineteenth-century business and finance. 
Chapter 3

Spinster Domesticity: Middle-Class Single Women's Appropriation of Motherly Roles in

Family Networks and Sunday Schools, 1830-1850

To my dear little Niece on her Birthday- Decr 24-1835

What--! seven years old! can it be true?

You surely must mistake my dear;

It seems but like a year or two,

Since first we bade you welcome here-

A few short days since first we looked and smiled

Upon the little, tiny, helpless child.

And yet when I the hours recall

Of sorrow passed through since that day;

And then remember above all

The countless mercies of way;

Oh then I think I could imagine even

That you had almost numbered three times seven-

But whether long or short the years,

You were a welcome little thing:

You found us full of anxious fears,

Pleasures of hope you came to bring--

Just like a beauteous beam of sunny light

When all the prospect round was dark as night.

And you have often been, my love,

Our little comforter and joy[.] ${ }^{354}$

Stashed away in a collection of family mementos, Catherine's touching birthday poem

dedicated to her niece serves as stirring evidence of her love and pride for her sister's child. This

ode bursts with the domestic imagery of motherly joy, affection, and pride by extolling the

pleasure she has derived from watching her niece, Lizzie Rawson, grow. Catherine's verses are

but one of many pieces of archival evidence which demonstrate how single women could

perform domestic, filial roles by caring for other women's children. As such, this chapter

${ }^{354}$ Catherine Read to Lizzie Rawson, December 24, 1835, MAR, MD 5694, SCA. 
addresses the concept of spinster domesticity and contributes to trends in historical literature that analyze the varied experiences of single, middle-class women in the nineteenth century.

\section{Spinsterhood: Limitations or Opportunities?}

The historiography on unmarried women in the late eighteenth and nineteenth centuries is divided into works that emphasize the limitations placed upon single women and case studies that acknowledge the opportunities open to them. Contemporary views on unmarried women, or as they were derogatorily called spinsters, assumed that single women's existence was automatically marginalized. The high number of women compared to men in nineteenth-century British society fed these stereotypes, leading many to fear for the fate of "surplus women [who were] doomed to an unhappily penniless and lonely existence." 355 Interestingly enough, early feminists established the first women's rights movement because of their concerns about women's vulnerability due to the population imbalance's impact on marriage opportunities, as many women relied on marriage for economic security. These women demanded reforms that would protect single and married women's interests, such as better education for women and married women's property and custody rights. ${ }^{356}$ The impact of these tropes continues to influence scholarship on this topic by furthering the assumption that unmarried women endured dissatisfied lives of poverty, disgrace, and shame.

Works like Bridget Hill's, for example, claimed that single women were dependent on their fathers and brothers for material support and as such were "regarded at best as an unpaid domestic servant [or] at worst a source of shame." ${ }^{357}$ According to Hill, their failure to marry

\footnotetext{
355 Phillipa Levine, "So Few Prizes and Many Blanks: Marriage and Feminism in Later Nineteenth-Century England," Journal of British Studies 28, no. 2 (1989): 150-74, 152.

356 Ibid.

${ }^{357}$ Bridget Hill, Women Alone: Spinsters in England, 1660-1850, (New Haven: Yale University Press, 2001), 2-3.
} 
relegated them to the "the background of family life" except during times of family crisis. ${ }^{358}$ More recent works focused on family networks, however, have repudiated the idea that all unmarried women remained un-empowered.

Many works have challenged the claim that spinsterhood represented a state of shame and degradation. Ruth Larsen's work pointed out that not all women intended to marry and that not all who chose "singlehood" did so due to poverty of money or personality. ${ }^{359}$ Moreover, those who decided not to marry were not necessarily ridiculed for it; instead, contemporaries lauded them as women of strong personal character who refused to marry if it meant "compromising [their] moral standards." 360 In other words, these women made conscious choices not to marry certain men despite receiving offers of marriage. Though some were "unlucky in love," others could not marry due to their responsibilities to family members. ${ }^{361}$ Similarly, Alison Duncan refuted the assumption that spinsters were not useful members of the family through her case study of the Adams, a Scottish family of landed elites. Duncan's work showed that even though families commonly used marriages as a means to secure their position and wealth, spinsters were not immediately viewed as "social and economic parasites." 362 Rather, many large families from the aristocracy and gentry chose to leave several children unmarried as a family strategy. ${ }^{363}$ Case studies of wealthy unmarried women therefore prove that they were crucial actors in the sustainment of the family network.

\footnotetext{
358 Hill, 3-4.

${ }^{359}$ Larsen, 388, 392.

360 Zsuzsa Berend, 'The Best or None': Spinsterhood in Nineteenth-Century New England,” Journal of Social History 33, no.4 (2000): 935-957, 936.

${ }^{361}$ Larsen, 390, 395. See also, Davidoff and Hall, Family Fortunes, 338, 342. Similarly, Ruth Perry’s chapter on aunt figures in nineteenth-century British literature argued that in literature women who were not related to motherless girls but took it upon themselves to aid and advise acted like aunts in their substitutionary maternal services. See Ruth Perry, "The Importance of Aunts," in Novel Relations: The Transformation of Kinship in English Literature and Culture, 1748-1818 (Cambridge: Cambridge University Press, 2004), 336-71.

362 Duncan, 11.

363 Ibid.
} 
Through the Adams' example, Duncan illustrates that even women who never married were active contributors to the family enterprise who used their networks to secure sources of patronage for their male family members and interceded during inter-family conflicts. ${ }^{364}$ What's more, Duncan's case study illustrates that only women who successfully fulfilled their roles as familial networkers and support systems earned their family members' esteem, respect, and protection. ${ }^{365}$ Despite their unmarried status, these women were also able to play powerful, important roles in their family networks by drawing upon their "natural" maternalism. If assumptions of unmarried women characterized them as "less able to fulfill the ideals of femininity," recent works like Larsen's and Duncan's pointed out that unmarried women often acted as "substitute motherers [by] nurturing and educating young relatives." 366 Larsen and Duncan demonstrated this through their study of Margaret Adam's and Harriet Cavendish's roles as "doting aunt[s]" and guardians of their nieces and nephews during their parent's absences or after their deaths. Duncan's study of Margaret Adam proves that the use of the term parent was not strictly biological; rather, it referred to individuals who performed roles associated with parenthood. ${ }^{367}$ This clarification shows that even contemporaries associated those women who fulfilled the offices of parental care with mother-like status.

Spinsters' engagement in the public sphere through philanthropic work also contests the stereotypical image of the isolated, despondent nineteenth-century unmarried woman. Single women's active participation in the anti-slavery movement and lower-class educational institutions like the Royal Jubilee School for Girls proved that these women were not confined to

\footnotetext{
${ }^{364}$ Duncan, 12. Margaret Adam wrote on her brother-in-law, John Clerk's, behalf to secure him patronage opportunities and promote his professional interests.

365 Ibid., 11, 17.

${ }^{366}$ Larsen, 388, 396, 392, 395.

${ }^{367}$ Duncan, 12.
} 
taking care of their elderly parents. Rather, associational activism enriched their lives by

providing them with outlets to help women and children within their communities and the wider world. ${ }^{368}$ This chapter will use the example of the Reads' two unmarried daughters, Catherine and Emily, to examine how single women utilized the ideology of domesticity to fulfill their societally sanctioned roles as nurturing mothers within their family networks and charitable work.

\section{Motherhood and Family Ties}

My work proposes that even though middle-class women like Catherine and Emily Read never married, they were able to draw upon their supposedly "natural" domestic roles by helping raise their sisters' children and educating children in charitable Sunday Schools. These channels provided them with outlets to assume duties as mothers, without transgressing the rules of propriety by having children outside of wedlock. Even though they were unmarried and childless, these middle-class women acted as "auxiliary mothers" to the children in their family and community by using these positions to perform their nurturing, pious, and moral nature; a concept that I call "spinster domesticity."369

In order to clarify how single women could participate in the domestic role of motherhood, perhaps it is first necessary to address what it meant to be a mother. During the years of this study, motherhood was discussed extensively in conduct books, the periodical press, and private correspondence. Though these sources offer representations of motherly ideals rather than true-to-life practices, they provide a crucial vantage point into a cultural phenomenon in

\footnotetext{
368 Jonathan Mood, "Women in the Quaker Community: The Richardson Family of Newcastle, c. 1815-1816," Quaker Studies 9, no. 2 (2005): 204-19, 215; Midgley, Women Against Slavery, 75-8.

${ }^{369}$ For more on the impact of enlightenment ideals on gender roles and the role of enlightenment values on domesticity in evangelicalism, see Davidoff and Hall, Family Fortunes; Twells, The Civilising Mission and the English Middle Class. I use the term "auxiliary mothers" to both describe middle class single women's roles as assistant mothers and also to play upon the fact that middle-class women formed "auxiliary societies."
} 
which some mothers celebrated their domestic and familial roles whereas others accepted it as their duty, obligation, and God's will. ${ }^{370}$ This study focuses on the former due to its prominence in Victorian maternal ideology. Along with the economic and social transformations in society, women's public depictions were increasingly shaped by middle-class ideas of domesticity that emphasized motherhood as a sacred duty. Beth Fowkes Tobin argued that this empowered conception of motherhood offered women the authority to question the patriarchy as well as to legitimate and support the gendered division of labor in the middle-class home. ${ }^{371}$

Contemporaries expected mothers to be good behavioral role models of modesty, morality, piety, thrift, and moderation and to develop close bonds with their children whilst overseeing the support staff who helped raise them—nurses, governesses, tutors, etc. ${ }^{372}$ They were also called to "nurture their children physically and emotionally without stint...to educate them, ...nurse them when ill, [and] watch over them anxiously at all times." ${ }^{373}$ Even women's "Christian status" emphasized their obligations to dedicate themselves to the "duties of home and family [within] their 'relative sphere' [as] wife and mother." 374 This last point reveals that marriage and motherhood had obtained such prominence in gendered ideas about women's societal roles that even their faith systems depicted a good Christian woman as a maternal figure. Nineteenth-century prescriptive literature offers a vantage point on how mothers were to carry out their maternal duties.

\footnotetext{
${ }^{370}$ See Amanda Vickery, The Gentleman's Daughter: Women's Lives in Georgian England (London: Yale University Press, 1998).

${ }^{371}$ Beth Fowkes Tobin, "The Tender Mother": The Construction of Motherhood and the "Lady's Magazine," Women's Studies 18, no. 2 (1990): 205-21, 217-8.

${ }^{372}$ Marilyn Francus, Monstrous Motherhood: Eighteenth-Century Culture and the Ideology of Domesticity (John Hopkins University Press, 2012), 12-13.

${ }^{373}$ Perry, 336-71, 340. See also Davidoff and Hall, Family Fortunes, 335-343.

${ }^{374}$ Hall, "The Sweet Delights of Home," 62.
} 
Prescriptive literature, conduct books, and periodicals clearly present expectations placed upon mothers. The popular Lady's Magazine, for example, depicted mothers as tender, sympathetic, selfless, and "anxious about their children's welfare." 375 These manuals show that motherhood meant more than giving birth to a child; women's duties as mothers were to use their affectionate feelings to raise their children to be upstanding, productive members of society. These sources instructed women to utilize their "natural" affection in order to inspire trust and obedience that would in turn enable them to shape their habits, beliefs, and feelings.

For example, Thomas Gisbourne's Enquiry into the Duties of the Female Sex (1810) observed that "the twig, however young and tender, may be bent and fashioned by the hand of gentleness." ${ }^{376}$ Others claimed that mothers" "natural" affection qualified them as teachers. Sarah Stickney Ellis' Mothers of England (1843) argued that “a mother's love, a mother’s watchfulness, and a mother's earnest zeal for the good of her children [authorized them as the best instructors for] the intellectual as well as moral education of [their] children." ${ }^{377}$ As this statement shows, motherhood entailed attention to the physical needs of their children as well as their basic education and moral development. In this role as educators, a mother's foremost responsibility was teaching their children Christian principles. On this subject, Fordyce's Sermons to Young Women (1809) beseeched mothers to "insinuate knowledge and piety by your conversation and example." ${ }^{378}$ It was therefore integral that mothers instructed the teachings of Christianity and modeled the actions of a good Christian. These sources underscore the connection between conceptions of motherhood and moral and religious education.

\footnotetext{
375 Fowkes Tobin, 209.

376 Thomas Gisbourne, An Enquiry into the Duties of the Female Sex, $8^{\text {th }}$ ed. (London: W. Heseltine, 1810), 381-2.

377 Sarah Stickney Ellis, Mothers of England: Their Influence and Responsibility (London: Fisher, Son, and C., 1843), 256.

378 James Fordyce, Sermons to Young Women, American ed. (Philadelphia: M. Carey, 1809), $26,28$.
} 
The messages presented to women in this literature demonstrate that contemporaries expected mothers to supervise the health and development of their children mentally, socially, and religiously by acting as kind, affectionate, and firm guides. My work shows that unmarried women could also fulfil these roles by utilizing their supposedly "natural" domestic natures. Catherine and Emily Read's correspondence evidences how they practiced the expected tenants of domesticity through their status as "auxiliary mothers." These letters reveal their services as nurturers, caretakers, advisors, and educators to the families of their married sisters. ${ }^{379}$

\section{The Reads' Family Network}

Catherine and Emily's experiences show that spinsters were critical actors in the family network. Their single status enabled them to act as support systems to their married sisters whose personal tragedies necessitated special aid: Mary Anne Rawson of Sheffield was a young widow with a sickly daughter and Eliza Wilson of Nottingham was a mother of a rapidly growing family with a frail constitution. ${ }^{380}$ Catherine and Emily performed crucial services by residing with their mother and Mary Anne in Sheffield or with Eliza and her husband, William Wilson, in

Nottingham or having the Wilson children stay with them in Sheffield for months at time. ${ }^{381}$ The

\footnotetext{
${ }^{379}$ Catherine Read to Anne Read, Torquay, May 3 [Suggested 1841-2], MAR, MD 5694, SCA; Catherine Read to Emily Read, [Suggested July 1844], MAR, MD 5694, SCA; Catherine Read to Joseph Read, Radford, August 27, 1831, MAR, MD 5694, SCA; Emily Read to Mary Anne Rawson, Radford, Wednesday, ND, MAR, MD 5696, SCA.

${ }^{380}$ Eliza Wilson was pregnant in 1829, 1831, 1832, 1833, 1834, 1836, 1837, and 1840 and had seven children (out of eight) that survived infancy. Catherine Read to Anne Read, Torquay, January 1, 1842, MAR, MD 5694, SCA; Emily Read to Joseph Read, Radford, November 27, 1832, MAR, MD 5696, SCA; Emily Read to Edmund Read, Radford, June 6, [Suggested 1831], MAR, MD 5696,SCA; Emily Read to Lizzie Rawson, Radford, February 2, 1833, MAR, MD 5696, SCA; Emily Read to Mary Anne Rawson, Radford, Wednesday, ND, MAR, MD 5696, SCA; Emily Read to Joseph Read, Radford, June 21, [Suggested 1831], MAR, MD 5696, SCA; Emily Read to Mary Anne Rawson, Radford, June 14, 1831, MAR, MD 5696, SCA. For information of Lizzie Rawson's frailty, see Taylor, "Life of Mary Anne Rawson," 6.

${ }^{381}$ Elizabeth Read to Eliza Wilson, The Mills, November 2, 1835, MAR, MD 2474, SCA. Single sisters commonly aided their married sisters in carrying out their domestic and household duties. See Sandra Stanley Holton, "Family Memory, Religion and Radicalism: The Priestman, Bright, and Clark Kinship Circle of Women Friends and Quaker History," Quaker Studies 9, no. 2 (2005): 156-75, 164.
} 
spinster sisters' letters prove their deep bond with their nieces and nephews as illustrated through the fact that they treated them as if they were their own children.

Catherine's birthday poem to her niece, which served as the opening vignette of this chapter, demonstrated her affection and fondness for her sister's daughter, Lizzie Rawson, by chronicling Lizzie's impact on both her own life and the family's. The reverence Catherine showed for the "little, tiny, helpless child" in her poem mirrored the same tone of adoration traditionally associated with a mother's bond with her infants. This "natural" connection was most certainly a trope and not a lived reality-- as proven by Queen Victoria's, notably the central figurehead of domesticity and motherhood in the Victorian period, own impatience and distaste for caring for her infant children. Nevertheless, the fact that contemporaries expected mothers to feel deep, personal attachments to their babies and dedicate themselves to their children's wellbeing reinforces the argument that Catherine assumed a mother-like role by playing upon these notions in her poem. ${ }^{382}$ She also utilized the same terms of affection to describe Lizzie as her sister Eliza's letters to her daughter, Mary Eliza Wilson, by referring to Lizzie as "my love." 383

In addition to proving Catherine's esteem and affection, the ode offered a touching chronicle of how Lizzie's presence blessed her family. Though Lizzie's birth and early childhood coincided with periods of “sorrow”-- the deaths Lizzie's father, William Bacon Rawson, her aunt (Catherine's sister), Sarah Read, her paternal grandparents, her maternal grandfather, Joseph Read, as well as the family's financial troubles; Lizzie gave her family "hope," "light," and

\footnotetext{
${ }^{382}$ Catherine Read to Lizzie Rawson, December 24, 1835, MAR, MD 5694, SCA; Davidoff and Hall, Family Fortunes, 339; Walter L. Arnstein, Queen Victoria (Basingstoke, Hampshire: Palgrave Macmillan, 2003), 58-9; Susan Kingsley Kent, Queen Victoria: Gender and Empire (Oxford: Oxford University Press, 2016); Hall, "The Sweet Delights of Home," 50.

${ }^{383}$ Catherine Read to Lizzie Rawson, December 24, 1835, MAR, MD 5694, SCA; Eliza Wilson to Mary Eliza Wilson, Letters of the Wilson Family (hereafter LWF), January 28, 1847, MD 2474, SCA; Eliza Wilson to Mary Eliza Wilson, May 13, 1847, Oak Hill, LWF, MD 2474, SCA.
} 
"joy." 384 This effusive account shows that Catherine loved her niece and saw her role as Lizzie's caregiver as a central aspect of her own life and her family's experiences as she described Lizzie's birth and growth as directly tied to the family's narrative.

Catherine and Emily also expressed their affection and filial bonds to their nieces and nephews through the many anecdotes shared in their letters. For example, Catherine delighted in reiterating a cute story about Eliza's daughter, Ruth Wilson, who was trying to tell her mother and Aunt Catherine about some "delightful eggs [which she (mistakenly) believed] came from a sort of pig." Catherine clarified that the "dear child...of course meant the Guinea fowl-- \& was confusing it, [she] suppose[d] with the Guinea pig." ${ }^{385}$ Catherine's endearment for her nieces and nephews and their growing sense of the world shined through in this example. Her report of such charming stories reflected not only her presence in the children's lives but also her joy in participating in these humorous, innocent moments.

Similarly, Emily expressed her affection and delight in Eliza's children. In one instance, she relayed Mary Eliza's antics as a toddler who, though she could not "say many words plain yet [was] a very drole [sp] child [that] laughs and makes such faces on purpose to amuse us, and screws up her little face to almost nothing. ${ }^{386}$ She also shared a charming account of William Cecil's demeanor as an infant. Emily confided that he was "such an affectionate little creature [who loved to] often kiss us all over our faces with his dear mouth quite wide open." ${ }^{387}$ These stories illustrate how Catherine and Emily's roles as "auxiliary mothers" to their sisters' children enabled them to experience the joys of motherhood. Despite societal expectations that mothers would thrive in the domestic bliss afforded by their children, women like Queen Victoria, who

\footnotetext{
${ }^{384}$ Catherine Read to Lizzie Rawson, December 24, 1835, MAR, MD 5694, SCA.

${ }^{385}$ Catherine Read to Anne Read, Torquay, May 3, [Suggested 1841-2], MAR, MD 5694, SCA.

386 Emily Read to Edmund Read, Radford, June 6, [Suggested 1831], MAR, MD 5696, SCA.

${ }^{387}$ Emily Read to Lizzie Rawson, Radford, February 2, 1833, MAR, MD 5696, SCA.
} 
preferred to allow nurses to carry out their motherly duties, demonstrate that Catherine and Emily's dedication and appreciation of their pseudo-motherly roles warrants recognition. ${ }^{388}$ Additionally, Catherine and Emily fulfilled parent-like roles by taking over supervision of the children in their sisters' absences. Catherine's letters prove that she took this post as guardian very seriously, calling it "such an important, responsible charge" and confessing that she was "scarcely easy [when they were] not in [her] sight." ${ }^{\text {" } 89}$ Similarly, another letter expressed her exhaustion after a trip to the beach at Watcombe. Catherine admitted that even though she was "very tired" after the excursion she could not bear the thought of staying at home while the children were at such a "dangerous place." ${ }^{" 390}$ These letters convey Catherine's sense of maternal affection, anxiety, and obligation towards her nieces and nephews.

Catherine also served another pseudo-motherly function as an advisor to her nieces and nephews. One of her letters helped her nephew, Johnny Wilson, prepare to return home at the end of the school year by recommending the best times to travel, identifying potential hardships and how to avoid them, and reminding him of social necessities expected, such as whom he should call upon in the area. She particularly sought to ensure that Johnny's trip would be as pleasant as possible by reminding him that he should have the school pack him a "sandwich" or buy something to eat at the "station" to sustain him for the long train ride home-- "or [he would] come home with a bad headache for fasting too long." ${ }^{191}$ These hints fulfilled a pseudo-motherly role by suggesting the best ways to come home for the holiday break and helping him to avoid the inconveniences and suffering of hunger and headaches. The two sisters also provided motherly services by caring for their nieces and nephews during periods of sickness.

\footnotetext{
388 See Arnstein, 58-9.

${ }^{389}$ Catherine Read to Anne Read, Torquay, May 3 [Suggested 1841-2], MAR, MD 5694, SCA.

${ }^{390}$ Catherine Read to Emily Read, [Suggested July 1844], MAR, MD 5694, SCA.

${ }^{391}$ Catherine Read to Johnny Wilson, December 11, [suggested 1837], Highstead, MAR, MD 5694, SCA.
} 
Catherine and Emily's letters demonstrate their maternal care and investment in their nieces' and nephews' health and well-being. For example, Emily wrote to advise their sister, Mary Anne, to fortify her daughter Lizzie's health with "regular meals of broth or gravy or beef teas" since she worried that Lizzie did not receive enough of "th[e]se nourishing kinds of things." ${ }^{392}$ This example shows that Emily felt knowledgeable enough about the subject that she advised her sister on how to take care of her own child. Catherine and Emily did not merely offer guidance, they also personally nursed their charges day and night throughout the stages of sickness and recovery. ${ }^{393}$ These services required Catherine and Emily to be brave in the face of anxiety and sometimes throughout gruesome medical procedures, such as Emily's (horrifying) account of supporting her niece, Mary Eliza, while the doctor drained her of "about a tea cup full of blood." ${ }^{394}$ In addition to medical knowledge, middle-class motherhood required a familiarity with the domestic apparatus required to raise children, including how to manage a household and its staff.

Catherine and Emily also mastered the necessary tools and structures to accommodate a large family. Wealthy women's motherly roles included overseeing a team of nurses, governesses, tutors, and maids who catered to child-centric parts of the home like the nursery and schoolroom. ${ }^{395}$ Though she was not their mother, Catherine was familiar enough with the routine practices of childrearing to identify the staples of ensuring the comfort of the entire

\footnotetext{
${ }^{392}$ Emily Read to Mary Anne Rawson, Radford, ND, MAR 5696, SCA.

${ }^{393}$ Elizabeth Read to Eliza Wilson, The Mills, November 2, 1835, LWF, MD 2474, SCA; Catherine Read to Mrs. Read, [Suggested April 21, 1841], MAR, MD 5694, SCA; Catherine Read to Emily Read, [Suggested July 1844], MAR, MD 5694, SCA; Catherine Read to Anne Read, Torquay, January 1, 1842, MAR, MD 5694, SCA; Catherine Read to Anne Read, Torquay, May 3, [Suggested 1841-2], MAR, MD 5694, SCA; Catherine Read to Joseph Read, Radford, August 27, 1831, MAR, MD 5694, SCA; Emily Read to Joseph Read, Radford, June 21, [Suggested 1831], MAR, MD 5696, SCA; Catherine Read to Joseph Read, Radford, August 27, 1831, MAR, MD 5694, SCA; Emily Read to Lizzie Rawson, Radford, February 2, 1833, MAR, MD 5696, SCA; Emily Read to Mary Anne Rawson, Radford, June 14, 1831, MAR, MD 5696, SCA.

${ }^{394}$ Emily Read to Mary Anne Rawson, Radford, January 21 [Suggested 1833], MAR, MD 5696, SCA.

${ }^{395}$ Davidoff and Hall, Family Fortunes, 399; Hall, "The Sweet Delights of Home," 81; Francus, 12-13.
} 
family and success in raising middle-class children. If the children were to be accommodated properly, they needed access to "proper nurseries, a schoolroom, [and] servants [like nurses who would see to their daily needs]." ${ }^{396}$ This comment highlights that Catherine was involved enough in their day-to-day care to understand the infrastructure necessary for middle-class children to grow and thrive.

Like biological mothers, Catherine and Emily's letters suggest that they were also invested in the education of their charges. In one letter to her brother Edmund, Catherine shared that she helped teach her niece Lizzie the alphabet and bragged that Lizzie had learned "many of her letters and always points to $\mathrm{U}$ for Uncle Edmund by gesturing to [his portrait in their mother's dressing room]. ${ }^{397}$ This interesting story suggested that Catherine assisted her sister in educating her child and also taught her one-year old niece about her family ties and relations.

Additionally, letters from Emily also illustrate her participation in the Rawson and Wilson children's education. Emily wrote to Johnny Wilson and Lizzie Rawson urging them to keep up with their lessons. ${ }^{398}$ She also shared a cute anecdote of teaching William Cecil Wilson the alphabet with a "large Board with... letters on [that] he... point[ed] [at] with his dear little finger... when [they] ask him where O is." ${ }^{399}$ These examples suggest that Catherine and Emily fulfilled motherly roles as educators. In addition to aiding and encouraging the children's formal education, Catherine and Emily also acted as "auxiliary mothers" by advising their nieces and nephews on religious matters.

\footnotetext{
${ }^{396}$ Catherine Read to Mary Anne Rawson, Plumptre House, [Suggested June 10, 1841], MAR, MD 5694, SCA.

${ }^{397}$ Catherine Read to Edmund Read, Wincobank, March 20, 1830, MAR, MD 5694, SCA.

${ }^{398}$ Emily Read to John Wycliffe Wilson, Wincobank, March 16, 1840, MAR, MD 5696, SCA; Emily Read to Lizzie Rawson, Radford, February 2, 1833, MAR, MD 5696; SCA.

${ }^{399}$ Emily Read to Lizzie Rawson, Radford, February 2, 1833, MAR, MD 5696, SCA. This appears to be the same method Catherine described in her anecdote about Lizzie Rawson learning the alphabet.
} 
Catherine and Emily's involvement in their nieces' and nephews' spiritual development demonstrates that their Congregationalist views influenced their stewardship of their charges, as both sisters stressed the importance of personal conversion and "the power of salvation and grace. ${ }^{" 400}$ Catherine actively contributed to the Wilsons' religious education by assisting the children in saying their morning prayers. ${ }^{401}$ Moreover, Emily's letters to Lizzie Rawson demonstrated her role as a spiritual mentor to her niece. Emily was distraught by Lizzie's continual inability to reach a state of personal salvation and conviction of Christ as her savoir. Consecutive letters from her aunt on Lizzie's seventeenth, twenty-first, and twenty-ninth birthday expressed Emily's disbelief that Lizzie had yet to fully commit her soul to God. ${ }^{402}$ In the foremost of these, Emily expressed her disappointment, asking Lizzie if it was "really possible that [she could] be seventeen, and still [her] heart not given to the Lord." Though this comment seems like criticism, Emily's objective was not to judge her niece, but to compel her to seek a personal relationship with Christ by beseeching her to "beg the Lord to take [her] heart and make it his." ${ }^{\text {"04 }}$ Emily's reference to "giv[ing]" one's "heart... to the Lord" reflected a trend in Evangelical piety that depicted "faith" [as a] living, busy, active mighty thing... which change[d] [individuals] and ma[de] [them]... born anew of God." ${ }^{405}$ In this way, Emily used personal milestones in Lizzie's life to remind her of the importance of inward faith and personal conversion.

\footnotetext{
${ }^{400}$ Hall, "The Sweet Delights of Home," 60-1; Tudur Jones, 147.

${ }^{401}$ Elizabeth J. Hale to Catherine Read, Oak Hill, August 17, 1845, MAR, MD 5694, SCA.

402 Emily Read to Lizzie Rawson, December 24, 1845, MAR, MD 5696, SCA.

${ }^{403}$ Ibid. Catherine also wrote to her aunt, Anne Read, on her birthday urging her to take her spiritual salvation more seriously. See Catherine Read to Anne Read, Torquay, January 1, 1842, MAR, MD 5694, SCA. Davidoff and Hall also noted an example of a letter from a mother beseeching her daughter to commit herself to her faith. See Davidoff and Hall, Family Fortunes, 340.

${ }^{404}$ Emily Read to Lizzie Rawson, Saturday, October 1, 1842, MAR, MD 5696, SCA.

405 Brunner, 79. John Wesley famously experienced a "warming" in his "heart" that led him establish Methodism. Also see, David Ceri Jones, "George Whitefield and Heart Religion," in Heart Religion: Evangelical Piety in England and Ireland,1690-1850, ed. John Coffey (Oxford: Oxford University Press, 2016), 100.
} 
Emily's guidance to her niece in these letters drew upon language of filial affection to counter any harshness as she urged Lizzie to take her personal salvation more seriously. In these letters, Emily replicated a model of evangelical motherhood established by her own mother, Elizabeth Read, that her sister Eliza Wilson also used in her letters to her daughter, Mary Eliza, expressing her "fear [that her] precious Child... [felt] less...earnest about [her] soul than [she] used to." ${ }^{\$ 06}$ Emily explained her repeated entreaties as the result of her inability to allow "such an important period of [Lizzie's] life to pass...without expressing some few of [her] earnest desires for [Lizzie]; all [her] most affectionate wishes that are... comprehended in one-that [Lizzie] may know Christ and be found in Him." ${ }^{.407}$

This notion of "know[ing]" Christ mirrored George Whitefield's popular evangelical concept of 'heart religion,' or that devout faith did not stem from external practices like fasting but rather "a knowledge... experienced at the core of one's being—in the heart and soul." ${ }^{408}$ For Congregationalists in particular, heart religion, or inward religion, did not mean "spontaneous emotion"- it required diligent personal "effort [and] manifested itself in a life of holiness [and] usefulness, in which public service, marriage, and family played a crucial part." ${ }^{409}$ The many pointed letters in this collection imply that Emily pestered her niece, however, they also suggest that this obsession about her personal salvation came from a feeling of obligation to her as an evangelical mother as testified by her mother's and sister's similar letters of entreaties to their children. These examples demonstrate that Catherine and Emily's services to their nieces and

\footnotetext{
${ }^{406}$ Elizabeth Read to Edmund Read, February 23, 1830, MAR, MD 5697, SCA; Elizabeth Read to Edmund Read, April 22, [Suggested 1830], MAR, MD 5697, SCA; Eliza Wilson to Mary Eliza Wilson, [January 1847], LWF, MD 2474, SCA; Eliza Wilson to Mary Eliza Wilson, November 28, 1847, Oak Hill, LWF, MD 2474, SCA; Eliza Wilson to Mary Eliza Wilson, May 13, 1847, LWF, MD 2474, SCA. For more on Elizabeth Read's evangelical, missionary motherhood, see Twells, The Civilising Mission and the English Middle Class, 88-89.

${ }^{407}$ Emily Read to Lizzie Rawson, December 23, 1849, MAR, MD 5696, SCA.

${ }^{408}$ Ceri Jones, 96-7.

${ }^{409}$ Rivers, 155.
} 
nephews and dedication to their welfare reflected the love and commitment of biological mothers. Their affectionate dedication to their sisters' children as nurturers, caretakers, and educators conformed with contemporary standards of motherhood and definitions of motherly care and duties espoused in nineteenth-century conduct books and periodical literature.

\section{Wincobank Sunday School}

In addition to supporting their sisters' children, Catherine and Emily also had the opportunity to practice "spinster domesticity" through their roles in the family's Sunday School. The Reads established a community chapel in the carriage house and a Sunday School in the laundry room of their home, Wincobank Hall, in 1817. In 1841, Mary Anne raised the funds to construct a building on the family's property which served as a new venue for church services, the Sunday School, and a day school. ${ }^{410}$ Wincobank Hall and its property served as the center of the family's many charitable enterprises, all of which promoted the religious and moral education of the poor. Like other scholars' works on women's philanthropy and domesticity, the spinster sisters' use of maternal tropes in their Sunday School work demonstrates how middleclass women manipulated conceptions of women's proper place to legitimize their engagement in the public sphere. ${ }^{411}$

Catherine and Emily's letters demonstrated that their philanthropic and evangelical goals gave them an obligation and interest in shaping the development and education of these children. As Twells' study on missionary work showed, middle-class women's status and values legitimized their role as models of morality, domesticity, and propriety. ${ }^{412}$ Catherine and Emily's work as Sunday School teachers reveals how their engagement in philanthropy ensured that the

\footnotetext{
410 Taylor, "Life of Mary Anne Rawson,” 4, 12.

411 Richardson, 14.

412 Twells, "Missionary Domesticity, Global Reform, and 'Woman's Sphere' in Nineteenth-Century England,” 267.
} 
children in their care received a proper moral and religious education. They utilized the principles of motherhood to guide and shape their Sunday School students.

Catherine's language in her letters to her Sunday School students reflected the terms of endearment and affection she used to address her nieces and nephews. This phenomenon suggests that Catherine wielded the language of familial sentiment, or even motherly affection, to build a relationship of esteem and trust with her students by referring to them as her "very dear children." 413 This strategy reflects Ellis' argument that a mother must employ her "naturally" affectionate nature in order for children to best learn proper behavior and principles. Moreover, it complicates the assumption that she used this role to assert her power over her lower-class neighbors by showing that she treated her Sunday School students similarly to her middle-class nieces and nephews. Regardless of any good intentions, however, the Sunday School's subject matter inherently promoted middle-class cultural and social interests as teaching children class appropriate behavior, worldviews, and moral principles formed a key part of middle-class children's formative education. In addition to Catherine and Emily's roles as teachers, the Read women also performed other services associated with motherhood for their community. Family letters note that Catherine, Emily, and their mother dedicated their free time to sewing and knitting for local children and making tippets and bonnets for the girls in their Sunday School. ${ }^{414}$ As a Sunday School teacher, Catherine employed maternal affection, scolding, and religiosity to guide her students to a righteous path.

In this position, Catherine also educated her students on seemingly secular and material matters. Though there is unfortunately not any reference to Catherine and Emily teaching their

\footnotetext{
${ }^{413}$ Catherine Read to her Sunday School Scholars, Ventnor, Isle of Wight, November 25, 1834, MAR, MD 5694, SCA; Catherine Read to Her Sunday School Girls, Torquay, April 5, [Suggested 1843-50], MAR, MD 5694, SCA. ${ }^{414}$ Catherine Read to Eliza Read, The Mills, September 20, 1813, MAR, MD 5694, SCA; Lizzie Rawson to Mary Eliza Wilson, Wincobank, January 11, 1843, MAR, MD 5698, SCA.
} 
Sunday School students to read and write, it is likely that they also taught these children basic literacy as many Sunday Schools covered these subjects in the nineteenth century ${ }^{415}$ Providing students with this skill served as a prerequisite for the model of faith espoused by evangelicals and Congregationalists, which stressed the importance of reading the Bible and developing a personal relationship with God. ${ }^{416}$ There is bountiful evidence, however, of other topics of instruction, such as matters of propriety. Catherine's tutelage was an opportunity for her to instruct her students, largely from the nearby village, in middle-class values and conduct. For example, after hearing about some of the Sunday School girls' "light trifling, frivolous [and] "bold....behavior... to some of the boys and young men in the neighborhood," Catherine felt obligated to share some "words of love and tenderness[, but also] words of reproof" with them. ${ }^{417}$ Her decision to share her affection as well as disapproval recollects Gisbourne's advice on how to raise one's children using affection and trust, demonstrating once again how Catherine's work as a Sunday School teacher reflected the qualities and purposes of motherhood. Moreover, Catherine's maternal role as a teacher directed her to remind her female charges of the consequences of such irresponsible behavior if it should remain unchecked. She scolded them for a lack of "regard for [their] own characters [and failure to] desire to be respectable, creditable young women.” This comment underscored Catherine's pseudo-motherly duty to educate lower-class young women to revere propriety and also relates to evangelicals' beliefs that Christian duty necessitated instructing and guiding others from the paths of $\sin .{ }^{418}$ These admonishments demonstrate that Sunday Schools were not only centers of religious

\footnotetext{
${ }^{415}$ Snell, 123, 130.

${ }^{416}$ Standish, 89, 91; Bebbington, Victorian Nonconformity, 3-5.

417 Catherine Read to Sunday School Girls, Torquay, April 5 [Suggested 1843-50], MAR, MD 5694, SCA.

${ }^{418}$ For more on Christians' duty to lead, forewarn, uplift, and sympathize with sinners, see Bebbington, Evangelicalism in Modern Britain, 11.
} 
education, but of moral and middle-class conduct. ${ }^{419}$ Catherine intoned to her students the risk of "bold" behavior with her statement, "you know, my dear girls, what such conduct generally leads to-- you know that improper familiarity with young men of your own age will, if encouraged, lead on to all sort of sin and misery." ${ }^{\prime 20}$ This comment underlined the link between sin, propriety, and women's honor to warn them away from a life of destitution and dishonor.

The letters indicated that Catherine felt obligated to help her students see the errors of their ways and the consequences of promiscuous types of behavior. In this example, however, Catherine appeared unable to fully express these consequences by either the standards of decorum, feminine "delicacy," or her own limited knowledge of the matter. ${ }^{421}$ Interestingly, Catherine expressed both her knowledge on these matters and her ignorance of the particulars. She was grateful that "through the providence of God [she had been] preserved even from hearing of the scenes of wickedness which... are common in our land [and] fe[tt]...scarcely qualified [to comment on it]." ${ }^{\wedge 22}$ This statement truly exemplifies the irony of Catherine's situation. On the one hand, as Alison Twells' work on women's charitable engagement in Sheffield and the British Empire has shown, middle-class women like Catherine Read viewed themselves as models and instructors of morality, domesticity, and propriety. ${ }^{423}$ On the other hand, Catherine found herself in a tricky position: how could she warn her students about this decidedly vulgar subject, which she herself was sheltered from by rules of propriety, and would likely feel uncomfortable speaking about as an unmarried woman?

\footnotetext{
${ }^{419}$ Reid, "Middle-Class Values and Working-Class Culture in Nineteenth-Century Sheffield," 269; Snell, 129-30.

${ }^{420}$ Reid, "Middle-Class Values and Working-Class Culture in Nineteenth-Century Sheffield," 233, 269; Snell, 12930.

${ }^{421}$ Davidoff and Hall addressed the complications mothers faced in advising their children against sexual immortality due to gendered constraints of "feminine delicacy." See Davidoff and Hall, Family Fortunes, 341. ${ }^{422}$ Catherine Read to her Sunday School Girls, Oak Hill, Torquay, April 5 [Suggested 1843-50], MAR, MD 5694, SCA.

${ }^{423}$ See Twells, The Civilising Mission and the English Middle Class.
} 
Her advice therefore was to recognize the negative examples within their own communities: "look at all the unsteady, wicked young women [they] $\mathrm{kn}[\mathrm{e}] \mathrm{w}$, and remember that [these women] once... indulged in giddy behavior just as [they were] doing, and perhaps thought as little ... of the consequences." Catherine reminded them that this negligence led to misery both on earth and in the afterlife: "a state of sin and wretchedness [that was] painful in the extreme to think of for a moment." It was not too late, however, to change their ways. Rather than follow this unhappy path, she asked them-- "will you not, my beloved girls, ask the Lord to be your guide?" 424 This example illustrates again how sexual purity was linked to morality and faith in nineteenth-century culture. By helping them to dedicate their lives to proper practices and devout faith, Catherine believed that she could save these girls from a life of ruin, material destitution, and eternal damnation.

Though Catherine may have felt uncomfortable or inadequate speaking about these matters, nineteenth-century anxieties about the seduction of young girls and the trope of the "fallen woman" made it a moral necessity to shield them against a dangerous, sinful world that sought to take advantage of their naiveite and indiscretion. ${ }^{425}$ As Rachel Fuch's work demonstrated, the "fallen woman" not only referred to those who lost their virtue or worked as prostitutes - it also included the lower-class 'Poor Mother' who failed to fulfill her responsibilities to take care of her home and family. ${ }^{426}$ Catherine, therefore, had to address this delicate subject in order to protect her students from a life of ridicule, shame, and suffering and to shield their future families from the neglect of a 'bad' mother. This example also demonstrates

\footnotetext{
${ }^{424}$ Catherine Read to Her Sunday School Girls, Oak Hill, Torquay, April 5 [Suggested 1843-50], MAR, MD 5694, SCA.

${ }^{425}$ Moira Martin, “Single Women and Philanthropy: A Case Study of Women's Associational Life in Bristol, 18801914," Women's History Review 17, no. 3 (2008): 395-417, 406. 426 Fuchs, 159.
} 
that even though middle-class women may have been well-intentioned in their attempts to "reform" lower-class women, by reinforcing middle-class values in their lessons they necessarily bolstered their own class position and cultural power. Nevertheless, this caveat should not suggest that middle-class women only looked to further their own "interest[s]" in supporting charitable work; rather, as Hans Medick and David Warren Sabean showed, the relationship between emotion and interest were much more blurred and complicated as interest directly shaped and defined emotion. ${ }^{427}$

Through this lesson, Catherine used affection to perform the role of an "auxiliary mother" by warning her "beloved girls" about the dangers of an irresolute life-- the duty of a good, respectable mother. Catherine's solicitude to her students also represented her gender specific duties as Christian to help these women — who she treated like members of her family by guiding them from sin and vice. ${ }^{428}$ Though it remains unwritten in her letters, surely Catherine hoped that her good motherly example would lead them to pass on these same lessons on conduct and faith to their own children.

Catherine and Emily's experiences as religious instructors in the Sunday School demonstrated how these roles provided them with opportunities to mother their charges by educating children on piety and faith. The Reads, as Congregationalists, were strict adherents of the importance of personal salvation and were therefore determined to utilize the Sunday School as a means for more than just basic literacy; they strove to promote religious education and the salvation of their community ${ }^{429}$ Catherine performed a motherly role in beseeching her students to form a deep, personal relationship with Christ by accepting him as their Savior. Like Emily's

\footnotetext{
${ }^{427}$ Hans Medick and David Warren Sabean, eds., Interest and Emotion: Essays on the Study of Family and Kinship (Cambridge: Cambridge University Press, 1984).

${ }^{428}$ Hall, "The Sweet Delights of Home," 62.

${ }^{429}$ Tudur Jones, 146.
} 
letter to Lizzie Rawson, Catherine utilized the model established by her own mother, Elizabeth Read, by encouraging her "children" to take their faith seriously and dedicate themselves to their inward, personal faith. ${ }^{430}$ One of Catherine's letters worked to impress upon her students the importance of spiritual salvation through the story of the death of a little girl. According to the story, the child appeared to be "a very good little girl" who enjoyed going to church, reading "good books," and singing hymns. Though she acted in a pious manner, her parents feared that "her heart might yet be unchanged." As Catherine pointed out, the child's delight in these activities did not guarantee the salvation of her soul because one could enjoy them without truly committing themselves to God. ${ }^{431}$

Catherine used the story to encourage her students to examine their religious convictions. The little girl in the story had accepted Jesus for her personal savoir and asked forgiveness for her sins and was therefore no longer afraid to die because she placed her trust in the Lord that he "would take her to live with Him in Heaven." Catherine asked her students if they were afraid to die and reasoned that they could not be if their sins were forgiven by Christ and their souls belonged to Jesus. She pleaded for those who were afraid of dying to "go to Jesus [with their fears] and ask Him not to cast you out." ${ }^{432}$ This letter demonstrated that she cared about more than outward respectability and conduct: she invested herself in the spiritual welfare of her students.

\footnotetext{
${ }^{430}$ Elizabeth Read to Edmund Read, February 23, 1830, MAR, MD 5697, SCA; Elizabeth Read to Edmund Read, April 22, [Suggested 1830], MAR, MD 5697, SCA. Taylor also noted that Elizabeth Read wrote to Mary Anne while she was away at school to coerce her to stop engaging in frivolous behavior, such as attending the theatre, because she feared it would lead to an impious lifestyle. See Taylor, "Life of Mary Anne Rawson," 3.

${ }^{431}$ Catherine Read to her Sunday School Scholars, Ventnor, Isle of Wight, November 25, 1834, MAR, MD 5694, SCA. Brown noted that nineteenth-century evangelicals used death to shock children and persuade them to follow the exemplary model shown in the account. See Callum G. Brown, The Death of Christian Britain: Understanding Secularisation 1800-2000 (London: Routledge, 2001), 65; Brunner, 79; Ceri Jones, 96-7.

${ }^{432}$ Catherine Read to her Sunday School Scholars, Ventnor, Isle of Wight, November 25, 1834, MAR, MD 5694, SCA.
} 
Catherine's dedication to her student's salvation suggests that Catherine's position as a Sunday School teacher was not merely a means for her to assert control over her lower-class neighbors; if she merely cared about appearance and her own social standing, she could have easily taught them how to maintain an outwardly pious and respectable lifestyle without troubling herself about the true status of her student's souls and their earthly happiness. Moreover, the fact that she had to make this speech proves that lower-class women did not necessarily conform to her middle-class standards-- they had autonomy and were ultimately outside of her middle-class influence. This acceptance of educational opportunities and ambivalence towards middle-class moral standards reflected a larger trend and explains why many lower-class families chose Nonconformist Sunday Schools, which were less authoritarian, rather than charity schools and day schools. ${ }^{433}$

As a testament to her concern for the state of their souls, Catherine shared a "little hymn about prayer" that she thought would help her students seek a real, emotional connection with God. One verse of this prayer warned that they "may as well kneel down and worship gods of Stone, As offer the living God, a prayer of words alone." ${ }^{434}$ These examples from the Sunday School letters emphasized the importance of personal salvation in Congregationalist theology. Outward actions were not enough to guarantee one's personal salvation—individuals had to have a true, personal conviction of God's grace. Like the little girl in the story, simply enjoying the trappings of faith—-hearing sermons, singing hymns, reading the Bible, going to Sunday School— did not equate with real piety, only a close, personal relationship with Christ

\footnotetext{
${ }^{433}$ Dennis Smith, Conflict and Compromise: Class Formation in English Society, 1830-1914; A Comprehensive Study of Birmingham and Sheffield (Boston: Routledge and Kegan Paul, 1982).

${ }^{434}$ Catherine Read to her Sunday School Scholars, Ventnor, Isle of Wight, November 25, 1834, MAR, MD 5694, SCA.
} 
guaranteed salvation. ${ }^{435}$ Catherine used cultural symbols of civilization and barbarousness to solidify the absurdness of relying on outward representations of faith without inward conviction.

The reference to "gods of Stone" in this prayer compared the audacity of praying routinely or passively to pagan practices that the British viewed as absurd, superstitious, and savage. ${ }^{436}$ Just as Catherine and her contemporaries found it ridiculous that the natives of empire worshipped idols, Catherine warned her students that it was not enough to "only say the words of prayer"-- they must really "pray from [their] hearts." This line especially underscored the importance of actively working to redeem one's soul-- not just saying the words but feeling them and meaning them. This concern was a part of the evangelical emphasis on the need for spiritual reform of the nation and the importance of "real religion" or "the capacity to lead a spiritual life." ${ }^{437}$ These examples illustrate that Catherine promoted the importance of personal dedication to Christ and that as an "auxiliary mother" it was her duty to educate, forewarn, and cajole her students into a closer relationship with Christ. ${ }^{438}$

Catherine and Emily viewed their role as educators not as a philanthropic pastime, but a deep, religious commitment to shepherding the young into a relationship with God. Emily's letter also illustrated the ways in which the single sisters acted as "auxiliary mothers" to others' children. Emily felt that this role was one in which they must lead by modeling a life of faith and piety for their students; an idea supported by Fordyce's Sermons. For this reason, Emily held reservations about entrusting her niece, Lizzie Rawson, with her own Sunday School class. She

\footnotetext{
${ }^{435}$ Hall, "The Sweet Delights of Home," 60-1; Dieleman, 29, 37, 46.

436 Twells, The Civilising Mission and the English Middle Class, 1, 19, 49-50.

${ }^{437}$ Hall, "The Sweet Delights of Home," 59; Brown, 36-7.

${ }^{438}$ Catherine Read to her Sunday School Scholars, Ventnor, Isle of Wight, November 25, 1834, MAR, MD 5694, SCA. This notion relates to Leslie J. Lindenauer's understanding of feminine Protestant piety that empowered women's ability to assert their influence within the family and the community through religious and charitable work. See Leslie J. Lindenauer, Piety and Power: Gender and Religious Culture in the American Colonies, 1630-1700 (New York: Routledge, 2002).
} 
doubted how well her niece could instruct and encourage others to save their souls, asking her "how [she could] tell the dear little children of the love and compassion of Jesus if [she had] never known it."439

Emily's letter shows that she discerned the serious implications of her positions as a Sunday School teacher. "Oh what important work you are entering on," she warned her niece, "the souls of six little ones... committed to your care, and you and they will have to give an account of the time you spend together at that day..., where the dead, small and great should stand before God." 440 This point revealed that, on the Day of Judgement, Sunday School teachers were responsible for acknowledging their own sins to God as well as success or failure in their work as religious instructors. This duty reflected middle-class mothers' serious responsibility to ensure their families' salvation. Emily's stern contemplation of Lizzie's readiness to serve as a Sunday School teacher also shows that this was not a frivolous hobby or pastime-- it was a serious endeavor with major consequences for the community that the Reads did not take lightly. Catherine and Emily's positions as Sunday School teachers demonstrate how they utilized motherly attributes such as affection, scolding, and compassion to persuade their students of the importance of spiritual devotion and the dangers of impiety and immorality. The daughters' letters show that the family's Sunday School served as a facet of their religious, moral, and educational outreach that allowed them to extend their familial roles beyond the nuclear family to encompass the neighborhood. Their decision to treat their Sunday School children with similar affection and conscientiousness as their nieces and nephews suggests that they imagined them as part of their larger, hyper-extended family that incorporated the villagers into their sphere of "spinster domesticity."

\footnotetext{
${ }^{439}$ Emily Read to Lizzie Rawson, Saturday, October 1, 1842, MAR, MD 5696, SCA.

440 Ibid.
} 


\section{Conclusion}

Despite the stereotypical image of spinsters as oppressed, unhappy figures in traditional scholarship, Catherine and Emily's poems and letters demonstrate that single women were crucial figures in their family networks and communities. Scholarship like Hill's that argued that unmarried women inevitably led cursed lives as unempowered drudges often reflected contemporary concerns about women's futures as "surplus women" due to the remarkable population imbalance between men and women in the nineteenth century. Larsen's and Duncan's works that analyzed case studies of wealthy single women, however, refuted these claims and noted that these women performed crucial, valued roles as support systems to their family network, as evidenced by their roles as networkers and domestic support systems. Both studies particularly addressed how single women helped their family members care for children. My work on the unmarried Read sisters extends this interpretation to middle-class spinsters.

This chapter develops the important role that spinster women played as domestic aids to their family by illustrating how these women could take on parent-like roles as "auxiliary mothers" by nurturing others' children—acts that led them to engage in "spinster domesticity." Catherine and Emily's services to their sisters' children and Sunday School students upheld the model established by contemporary conceptions of motherhood. They demonstrated deep ties of care and concern by utilizing language of affection, caring for their charges' physical and moral wellbeing, and serving as mentors and teachers in their formative, moral, and religious education. Nineteenth-century prescriptive literature offered even more evidence of single women's ability to perform mother-like roles by proving that most tasks associated with motherhood - affectionate, gentle, dedicated care for children's emotional, physical, and moral well-being—were not inherently biological. 
What's more the personal circumstances of the Reads' family network demonstrate that married sisters relied on the aid provided by their unmarried siblings. Without Catherine and Emily's help, Mary Anne Rawson and Eliza Wilson would have struggled to raise their families due to Mary Anne's early widowhood and her daughter's sickliness and to Eliza's health problems and near constant pregnancy for an eight-year period. ${ }^{441}$ Archival evidence such as sweet birthday poems and touching anecdotes show that the spinster sisters relished aiding their married sisters' children and formed affectionate bonds with them. These examples reveal Catherine and Emily's reverence for their nieces and nephews and their delight in their growth and development. Nevertheless, their experiences were far from fair-weather or easy tasks - they assumed responsibility for their sisters' children in their parents' absences and worried about their safety, advised them on practical matters, took care of them while sick, and invested in their well-being. Catherine and Emily also fulfilled a crucial role emphasized in conduct literature on motherhood: instructing children in educational and spiritual matters.

In their services as dedicated aunts, Catherine and Emily committed themselves to the formative, religious, and moral education of their nieces and nephews. They taught their sisters' children how to identify letters of the alphabet and encouraged them to be studious and dedicate themselves to their lessons. They also served as examples of piety by leading them in prayers and stressing the importance of personal faith, spiritual conversion, and inner commitment to Christ as their Savior. In this last example, both sisters played upon a model established by their own mother's attentiveness to their childhood spiritual development. This concern with spiritual education and personal salvation would carry into their relationships with their Sunday School students.

${ }^{441}$ Eliza gave birth to a child every year from 1829-1837 except for 1830 and had her last child in 1840. 
The Reads' engagement in the Sunday School was a direct part of their charitable and religious outreach within their community, which they saw as part of their duty to help the Wincobank villagers and their children. Middle-class women's participation in philanthropic work like Sunday Schools reflected the ideology of domesticity and notions of their status as moral and domestic authorities, which qualified them to teach the lower classes on moral, domestic, and spiritual matters. In order to instruct other women's children, Catherine and Emily utilized the persuasive measures recommended to mothers in conduct books by offering affection, gentle scolding, and firm direction to guide students much like mothers watched over their own children. This mother-like service included teaching their Sunday School students the importance of propriety and reserve by warning them of the path from sinful indiscretion to misery on earth and eternal damnation in the afterlife. In discussing topics like seduction and prostitution, Catherine had to stretch the boundaries of gendered norms on propriety and delicacy. Nevertheless, her pseudo-motherly status in steering her charges on the right path and the necessity of these lessons excused her venturing into a somewhat uncomfortable topic.

In addition to these moral lessons, Catherine and Emily's letters also offered insight into Congregationalist beliefs as seen through their emphasis on personal salvation. Their focus on entreating their students to dedicate themselves to their personal salvation and accept Christ as their Savoir directly corresponded to their mother's emphasis on this subject in their religious development. This commonality suggests that they did not view their students as less important than their immediate family members - they used the same methods to encourage both types of children. Moreover, their personal faith demonstrated that piousness was about more than surface level commitment and participation in religious life; one could not just listen to sermons, sing hymns, and attend Sunday School—-they must engage in personal reflection about their sins and 
the state of their soul. This definition of inward spirituality reflected the sisters' own understanding of their evangelizing role in the community as Congregationalists: their status as Sunday School teachers was a serious responsibility because it entailed commitment to ensuring the spiritual salvation of others.

Catherine and Emily's example concurs with recent scholarship on unmarried women by stressing their engagement with their family, community, and religious networks. This case study of Catherine and Emily Read demonstrates that even if contemporary stereotypes like those found in nineteenth-century novels ${ }^{442}$ derided spinsters as poor, burdensome, and problematic, this trope was not pervasive in practice. Some, like Catherine and Emily, drew upon their family networks and charitable work to practice their socially accepted roles as "auxiliary mothers." Their letters demonstrate that they carried out similar tasks to those associated with motherhood by participating in affectionate care and supervision, education, and religious instruction of children. These examples show that even childless, unmarried women were able to utilize the ideals of women's inherent domestic nature to strengthen their family and community. As "auxiliary mothers" and proponents of "spinster domesticity," Catherine and Emily served as support systems that ensured the protection and success of their family's and community's future generations.

${ }^{442}$ See Miss Bates in Jane Austen's novel Emma and Miss Havisham in Charles Dickens' Great Expectations. 


\section{Chapter 4}

Going Tea-Total: Women, Sociability, and Domesticity in Teetotal Events in Sheffield, 18301850

Jane Austen famously wrote that "there is nothing like staying at home for real comfort." ${ }^{\prime 43}$ For the Rawsons of Sheffield, this saying certainly rang true. A friend of the family even claimed that Wincobank Hall, like heaven, was "difficult of access, but a sweet happy place of rest when arrived at and inhabited by an angel."444 This comment illustrates how Wincobank Hall was not merely the family's haven; it was simultaneously a domestic, social, and philanthropic space where the family welcomed like-minded, influential friends like George Bennet, James Montgomery, Frederick Douglass, and Giuseppe Mazzini and provided charitable outreach to the lower classes. ${ }^{445}$ Accordingly, Wincobank Hall and its mistresses serve as a model to explore the importance of sociability and the home within the temperance movement. ${ }^{446}$ This chapter reveals how middle-class women deepened their involvement in the temperance movement by utilizing their domestic roles to sponsor spectacular teetotal events that blended the public and private.

\section{Temperance and Reforming Domesticity}

The British temperance movement emerged in the 1830 s as a response to the perceived problem of working-class drunkenness-- a concern particularly prominent amongst

\footnotetext{
443 Jane Austen, "Emma," in Jane Austen: Seven Novels, compilation by Barnes and Nobles (New York: Barnes and Nobles, Inc., 2007), 801.

${ }^{444}$ Mary Anne Rawson, “The Memorials of James Montgomery,” JMC, SUA.

${ }^{445}$ George Bennet was a famous missionary living in Sheffield; James Montgomery was a renowned poet and advocate for the working classes in Sheffield; Frederick Douglass and Giuseppe Mazzini were prominent figures within the anti-slavery movement and Italian nationalism respectively.

${ }^{446}$ I am developing Twells' argument that Wincobank Hall was the center of the Reads' philanthropic work and Vickery's claim that the home was not merely restricted to the private sphere. See Twells, "Missionary Domesticity, Global Reform and 'Woman's Sphere' in Early Nineteenth-Century England;" Vickery, The Gentleman's Daughter.
} 
evangelicals. ${ }^{447}$ The British and Foreign Temperance Society, created in 1831, was first the national society established to address this vice. To diminish the drinking of spirits, especially gin, temperance societies pushed for the Beer Act of 1830 that supported the opening of more pubs to decrease the consumption of liquor. The act, however, only encouraged more people to drink beer and did not decrease drunkenness. As a result of the perceived failure of this measure, a growing number of activists - known as teetotalers-- began to demand absolute abstinence from all forms alcohol ${ }^{448}$ Teetotalism was especially prominent amongst the working classes of Northern England who had first-hand knowledge and experience of the evils of drink. ${ }^{449}$ The rising popularity of teetotalism led to tensions in the late 1830s and early 1840s with moderates in the movement (predominately from the middle class) who suggested that only spirits were harmful and teetotalers who advocated abstinence from all types of alcohol. ${ }^{450}$ By the mid-1840s, teetotalism was the most popular ideology in the temperance movement. A key element of teetotal ideology was its villainization of the public house and idolization of the private home.

Teetotalers contrasted the good, wholesome recreations of the middle-class home with the dissipation of the public house. They championed the notion that all the evils of modern, urban life-- fornication, poverty, dirtiness, and disease-- were caused by drunkenness. In truth, these living conditions were not caused by drunkenness; rather, dirty, crowded dwelling spaces contributed to a high rate of drinking because the pub served as a working-class "recreational centre." ${ }^{451}$ Teetotalers were not unaware of this problem, even if they were unrealistic about the

\footnotetext{
${ }^{447}$ Andrea Broomfield, Food and Cooking in Victorian England: A History (Westport, CT: Praeger, 2007), 64.

${ }^{448}$ Erika Rappaport, "Sacred and Useful Pleasures: The Temperance Tea Party and the Creation of a Sober Consumer Culture in Early Industrial Britain," Journal of British Studies 52, no. 4 (2013): 990-1016, 1000. Rappaport also suggests that disillusionment with the limited amount of political participation extended to men in the Reform Act of 1832 served as another rallying point.

${ }^{449}$ Brian Harrison, Drink and the Victorians: The Temperance Question in England, 1815-1872 (Pittsburgh: University of Pittsburgh Press, 1971), 128.

${ }^{450}$ Reid, "Middle-Class Values and Working-Class Culture in Nineteenth-Century Sheffield," 373, 395.

${ }^{451}$ Harrison, 46.
} 
degree to which the odds were stacked against the working classes. ${ }^{452}$ For these reasons, teetotal advocates harangued about the strains that alcohol placed on the working-class family.

Teetotalers emphasized how drink made working-class families suffer; they commonly spoke out against men who used their paychecks to drink instead of provide food and clothing for their families and denounced drunkards' proclivities for domestic abuse. ${ }^{453}$ The most controversial cases, however, involved working-class mothers who were too drunk to fulfill their familial and domestic responsibilities. ${ }^{454}$ In each of these scenarios, teetotalers pointed out how drinking caused the neglect of household and familial duties.

In contrast, teetotalers advocated the importance of domestic practices like taking tea that encouraged families to stay home and develop close, affectionate ties. ${ }^{455}$ Tea drinking originated as an "afternoon social occasion [practiced] predominately [by Nonconformists, which] gradually spread" throughout other parts of English society in the $1840 \mathrm{~s} .{ }^{456}$ This trend was spurred by the rising prominence of tea and coffee in the mid-eighteenth-century. ${ }^{457}$ By the Victorian period, taking tea became an inseparable part of English middle-class domestic and social rituals and their national identity. ${ }^{458}$ Teetotalers championed these beverages as ideal

\footnotetext{
${ }^{452}$ Harrison, 132. Harrison claimed that teetotalers rightly presented sobriety as a choice between "two dramatic alternatives" in the decision to be sober or to be a drunkard, but that they "exaggerated the extent to which [the individual] was in command of [their] own fate."

${ }^{453}$ Ibid., 46-7, 128-9, 175, 321; Geddes Poole, 175. See also Hall, “The Sweet Delights of Home,” 78-80.

${ }^{454}$ Fuchs, 159.

455 This teetotal idea responded to a central theme of nineteenth-century middle class culture. Catherine Hall's study of the Queen Caroline Affair provides further evidence of the importance of domestic relations within the home in nineteenth-century England by revealing that public interest in the affair sought to protect the Queen and the nation by bolstering "the brightest ornament of English civilization[-] its 'domestic virtue.' See Hall, "The Sweet Delights of Home," 48.

${ }^{456}$ Harrison, 302.

${ }^{457}$ Rappaport, 995.

${ }^{458}$ Jule E. Fromer, A Necessary Luxury: Tea in Victorian England (Athens: Ohio University Press, 2008); Broomfield, 59.
} 
alternatives to alcohol because of their economy and relative safety compared to other nonalcoholic options like milk and water, which were still highly unsanitary. ${ }^{459}$

Teetotalers created a paradigm in which tea and alcohol were diametrically opposed to each other, posing alcohol as the root of working-class suffering and tea as its solution. For example, a teetotal procession in Cardiff used tableaus to contrast the "home of a drunkard" with a teetotal family gathering. The former scene included shabby furniture, a brow-beaten, abused wife, dirty, starving children, and a violent husband, whereas the latter showed a "well-dressed [family] taking tea together in a room comfortably furnished." ${ }^{460}$ Teetotalism's emphasis on familial security and domestic happiness attributed particular authority to women.

Elite women's participation in the teetotal movement focused on the problem of drunkenness within the working-class family. These women cited their concern for workingclass families, especially women and children, as a rallying point for their interference in working-class homes. ${ }^{461}$ Contemporary ideas about middle-class women's roles as domestic and moral authorities enabled them to serve the working classes as instructors on proper domestic practices and moral values. In order words, their gender roles positioned them as best qualified to address societal concerns about drunkenness and family bonding. ${ }^{462}$ As authorities on domestic life, these women held the skill sets necessary to address working-class family challenges.

\footnotetext{
${ }^{459}$ Harrison, 92.

${ }^{460}$ Paul O' Leary, Claiming the Streets: Processions and Urban Culture in South Wales, c. 1830-1880 (Cardiff: University of Wales Press, 2012), 110. For more on how tea was attributed with meaning and contrasted with alcohol, see Rappaport, 991.

${ }^{461}$ Geddes Poole, 104-5.

462 Several scholars have made this point. See Rappaport, 1007; Cowman, 212-213; Twells, "Missionary Domesticity, Global Reform, and 'Woman's Sphere' in Nineteenth-Century England," 268, 279; Twells, The Civilising Mission and the English Middle Class, 9; Midgley, Women against Slavery. Though my work focuses on British middle-class women's philanthropy, Ruth M. Alexander's study of lower-middle- and working-class American women demonstrates that their activism adopted a specific version of domesticity suited to their needs as workers, mothers, and family-members of artisans. See Ruth M. Alexander, 'We Are Engaged as a Band of Sisters': Class and Domesticity in the Washington Temperance Movement, 1840-1850," Journal of American History 75, no. 3 (1988): 763-785. For a French example, see Christine Adams, "Constructing Mothers and Families: The Society for Maternal Charity of Bordeaux, 1805-1860,” French Historical Studies 22, no. 1 (1999): 66-86.
} 
Therefore, they were perfectly placed to teach working-class men and women to cultivate middle-class definitions of the home-- a clean, pious, domestic space apart from the temptations and chaos of the outside world. ${ }^{463}$ Working-class families in turn adapted middle-class masculine and feminine ideals to suit the realities of their lives as workers; they stressed men's roles as protectors of dependents within their families and women's as providers of domestic services rather than as moral centers and household managers. ${ }^{464}$ In addition to creating a happy home and family, teetotalers also expounded on the gains that accompanied a sober lifestyle to inspire people to abstain from alcohol.

A central aim of the teetotal movement encouraged the working classes to seek respectability by embracing such "middle-class" values as thrift and sobriety. ${ }^{465}$ Teetotalers believed that when the working classes stopped drinking, they began the process of becoming respectable individuals. This transformation, however, was individual and could not be coerced. ${ }^{466}$ For teetotalers, the first step towards gaining respectability was to sign the personal pledge to renounce alcohol. ${ }^{467}$

Signing the teetotal pledge was hard on one's social life, for rich and poor alike. Choosing this path meant that the working classes had to relinquish relationships with those who continued to drink. ${ }^{468}$ Their decision to cut these ties often created hostility as former

\footnotetext{
${ }^{463}$ Reid, "Middle-Class Values and Working-Class Culture in Nineteenth-Century Sheffield."

${ }^{464}$ Hall, "The Sweet Delights of Home," 81; Meg Gomersall, "Women's Work and Education in Lancashire: A Response to Keith Flett," History of Education 18, no. 2 (1989):153-62, 162; Anna Clark, The Struggle for the Breeches: Gender and the Making of the British Working Class (Berkeley: University of California Press, 1995). ${ }^{465}$ The Temperance movement was not the only nineteenth-century reform interest which sought to improve the lives of the working classes by reforming their personal habits. Rather, it was just one "part of a broader middleclass social practice of self-improvement and benevolence that sought to inculcate thrift and good behavior amongst workers." See Rappaport, 1003.

${ }^{466}$ Harrison, 115.

${ }^{467}$ Ibid., 132.

${ }^{468}$ Ibid., 132-3.
} 
acquaintances saw their rejection of drink and pub culture as pretentious. ${ }^{469}$ Moreover, the importance of wine and port to conventions of elite sociability like the dinner party made the pledge a difficult choice for the middle classes as well. According to Caroline Reid, this sacrifice was the reason that most of the English middle class remained moderates-those who only opposed the consumption of spirits. Mary Anne alluded to the awkwardness caused by her teetotalism when she admitted that "one of the greatest trials [she faced] in embracing Teetotalism was... cutting off from offering a glass of wine to [her friend, James Montgomery]. ${ }^{470}$ These factors show that when they signed the pledge, teetotalers essentially had to create a new life for themselves. Though the initial step was individual, teetotal societies played a crucial role in the path to sobriety.

Teetotal societies helped their members bear their isolation and fostered commitment to their new lifestyle by utilizing material objects as symbols that acknowledged their hard work and perseverance. These outward expressions of commitment held symbolic importance: badges, regalia, flags, and banners served as external evidence of their dedication to the cause. Moreover, these symbols represented outward signs of the inward changes in their lives making them visibly recognizable to others. ${ }^{471}$ Visibility also helps explain the importance of demonstrating one's beliefs and commitment to the community in teetotal events like processions. Like the objects these events used, teetotal events proudly exhibited dedication to the teetotal cause. As Paul O' Leary's study of processions showed, these events were "as much about being on display

\footnotetext{
${ }^{469}$ Harrison, 133.

${ }^{470}$ Reid, "Middle-Class Values and Working-Class Culture in Nineteenth-Century Sheffield," 395. See Mary Anne Rawson, "Memorials of James Montgomery," JMC, SUA.

${ }^{471}$ Harrison, 132.
} 
in a public place as ... about achieving an aim. ${ }^{, 472}$ Engagement and activism also played a key role in the teetotal mission.

Teetotal societies served as both the replacement for supposedly unsavory working-class pastimes and the training ground for their new, more respectable lifestyles. These clubs fostered commitment amongst members by giving them responsibilities as officers and recruiters urging more people to the teetotal cause. ${ }^{473}$ By making them active members of the society, these associations helped individuals to commit to their new lifestyle and avoid temptations. These societies also served important social functions.

Teetotal meetings replaced past entertainments associated with drinking to serve as a substitute for the traditional center of working-class sociability - the pub. Teetotal societies had to foster the same spirit of community and entertainment associated with the pub. For this reason, teetotal meetings took common sources of amusement in pub culture and reformed them into respectable forms of entertainment. Just as individuals gathered to mingle, tell stories, and sing songs in the pub, teetotal meetings offered their members opportunities to hear reformed drunkards or teetotal speakers share cautionary tales and sing wholesome teetotal songs. ${ }^{474}$ These activities not only helped members to keep their pledges, but also introduced them to fellow abstainers by providing an opportunity for socialization and amusement. In addition to meetings, teetotalers also sponsored tea parties as respectable recreational activities.

Like teetotal meetings, tea parties provided alternative social engagements to replace the pub. Though much scholarship has been dedicated to the temperance movement, Erika

\footnotetext{
${ }^{472}$ O' Leary, 4. Similarly, Katrina Navickas has analyzed the political uses of adornment in her study of the role of symbolic articles like sashes and vestments in creating solidarity amongst radicals. See Katrina Navickas, 'That sash will hang you': Political Clothing and Adornment in England, 1780-1840," Journal of British Studies 49, no. 3, (2010): 540-565, 540, 542, 544.

${ }^{473}$ Harrison, 132-3.

${ }^{474}$ Ibid., 129.
} 
Rappaport's article offers the most in-depth analysis of temperance teas. According to Rappaport, temperance teas served as tutorials where women demonstrated proper, domestic practices to encourage the working classes to adopt them into their lifestyles. ${ }^{475}$ These events placed serious emphasis on such domestic ideals as proper table etiquette. ${ }^{476}$ They also provided proof of the enjoyableness of taking tea. Through these events, temperance societies enchanted their guests with visions of "the sweet life [to persuade them that] the rejection of certain material pleasures would bring an ever-lasting world of copious food, moral drinks, and domestic happiness. ${ }^{477}$

I argue that teetotal teas played a double role. First, as Rappaport suggests, they provided sociability, practice in respectability, and encouraged consumption of respectable goods. ${ }^{478} \mathrm{In}$ addition to this, these events helped the working classes to see the economic and social advantages of gathering for refreshments in their own homes rather than the pub. As Rappaport pointed out, teatime was associated with friends and family coming to the home to engage in polite conversation. ${ }^{479}$ This would be particularly important for showing working people alternative domestic habits. Teetotal events like these tea parties represent a new and fruitful area in historical scholarship that reveals middle-class women's unrecognized leadership in teetotalism.

Seminal works on the temperance movement, like those by Brian Harrison, focused on its male leaders and often downplayed women's involvement as frivolous efforts by disregarding the validity of their contributions as members of "ladies committee[s]" who hosted bazaars and

\footnotetext{
475 Rappaport, 993.

${ }^{476}$ Ibid., 992-3. Harrison also mentioned that tea parties were a means of promoting respectability and social mobility amongst the working classes. Harrison, 92.

${ }^{477}$ Rappaport, 1004.

${ }^{478}$ Ibid., 992.

${ }^{479}$ Ibid.
} 
teas. ${ }^{480}$ By studying activities like temperance teas in depth, however, scholars like Rappaport shed light on the important roles played by middle-class women and the events they organized. Through these charitable societies, women legitimized their presence in the public sphere as reforming agents and instructors on proper domestic practices-- a common theme in women's involvement in philanthropy. ${ }^{481}$ These "wealthy women" were active participants in this movement who contributed their "money, food, space, and time" to these societies. ${ }^{482}$ These four categories directly correlated to women's domestic roles as housekeepers and hostesses who managed their families' use and consumption of these commodities. For this reason, Rappaport's four categories and the gendered nature of sociability are integral to understanding the success of these events and women's contributions to the broader temperance movement.

My work on the Rawsons' activism in teetotalism expands upon Rappaport's study of temperance teas to demonstrate further the relationship between middle-class women's engagement in teetotal activism, domesticity, and sociability. Past works on temperance undervalued women's participation in these events, which created the false impression that women did not play active roles within these societies until the 1870 s. $^{483}$ Even an early biographical study of Mary Anne Rawson dismissed her work in the Wincobank Total Abstinence Society because it was "limited to teetotal teas and festivals." ${ }^{484}$ I, however, argue that these events were crucial contributions to the teetotal movement that demonstrate the relationship between middle-class women's philanthropic activism and gendered conceptions of

\footnotetext{
${ }^{480}$ Lillian Lewis Shiman, Crusade Against Drink in Victorian England (New York: St. Martins Press, 1988$), 182$.

${ }^{481}$ Several scholars have illustrated this point. See Rappaport, 1007; Cowman, 212-213; Twells, "Missionary Domesticity, Global Reform, and 'Woman's Sphere' in Nineteenth-Century England," 268, 279; Twells, The Civilising Mission and the English Middle Class, 9; Midgley, Women Against Slavery.

482 Rappaport, 1007.

${ }^{483}$ Lewis Shiman, 186-7.

484 Taylor, "Life of Mary Anne Rawson," 15.
} 
domesticity and sociability. The Rawsons and the Wincobank Total Abstinence Society

(hereafter WTAS) provide a window to analyze women's leadership in the teetotal movement.

\section{Temperance in Sheffield: The Reads and the WTAS}

The temperance movement in Sheffield emerged in response to an alarming rate of public drunkenness. Although it had a smaller population than most "industrial towns," Sheffield had as many "pubs and beerhouses" as larger cities. Even more alarmingly for contemporaries, it had the second highest rate of "prosecutions for drunkenness." 485 John Holland's Picture of Sheffield (1824) seconded this view of Sheffield's tendency towards "drunkenness and riot[, which he claimed were] exhibited in an alarming degree... with the most pernicious effects upon the rising generation." 486 Public concerns about drunkenness generated the creation of the Sheffield Temperance Society in September of 1831 which, unlike most temperance societies, featured the effective coexistence of moderates who advocated for abstaining from spirits and teetotalers who swore off all intoxicants. ${ }^{487}$ Successful cooperation between the moderates and teetotalers in the Temperance society meant, however, that the Sheffield Temperance Society was short-lived. By 1841, the temperance society was renamed the Sheffield Total Abstinence Society. ${ }^{488}$ This unique circumstance raises fascinating insights about the Rawsons' WTAS.

The WTAS was a family association that did not have any formal affiliation with Sheffield's teetotal organizations. It is unlike other societies established in Sheffield at this time and the family's other charitable works. ${ }^{489}$ The Rawsons were not members of the local temperance society in Sheffield. This is surprising as the family were active members of the

\footnotetext{
485 Pollard, 29.

${ }^{486}$ Holland, The Picture of Sheffield, 85.

${ }^{487}$ Reid, "Middle-Class Values and Working-Class Culture in Nineteenth-Century Sheffield," 394, 399.

${ }^{488}$ Ibid., 400.

489 Taylor, "Life of Mary Anne Rawson," 15.
} 
city's anti-slavery movement, Sunday School Union, Society for Bettering the Condition of the Poor, and Lancastrian schools before the 1840s. Furthermore, most middle-class temperance advocates were moderates (anti-spirits) whereas the Rawsons were firmly teetotal and extreme in their views on total abstinence; they refused to drink wine even for communion rites or medicinal purposes. ${ }^{490}$ In addition to their unique stance and views, the Rawsons' WTAS was also uncommon in terms its nature, leadership, and venue.

Mary Anne Rawson's primary aim in starting the WTAS in November of 1840 was to help the people of Wincobank. ${ }^{491}$ This is not surprising based upon the family's long history of charitable engagement in the village; in 1817, they converted their carriage house into a public chapel and their laundry room into a Sunday School for the Wincobank villagers. ${ }^{492}$ Mary Anne was particularly worried about local harvesters whose "thirsty work" was traditionally rewarded with a gift of "three to five quarts of cider per day per man." Fearing that this practice contributed to drunkenness, Mary Anne suggested that the custom be corrected and "coffee or tea" be offered instead. ${ }^{493}$ Mary Anne's decision to form the WTAS demonstrated her sense of maternalistic duty to assist the villagers as an middle-class woman of means. ${ }^{494}$ In other words, her concern for the wellbeing of the families at Wincobank mirrored her status as a caretaker and mother within the family network and empowered her with a conviction of the necessity of educating others about the dangers of drink.

\footnotetext{
${ }^{490}$ Taylor, "Life of Mary Anne Rawson," 15.

${ }^{491}$ Ibid.

${ }^{492}$ See Twells, The Civilising Mission and the English Middle Class, 87.

${ }^{493}$ Taylor, "Life of Mary Anne Rawson," 15.

${ }^{494}$ Graham Seal, "Tradition and Agrarian Protest in Nineteenth-Century England and Wales," Folklore 99, no. 2 (1988): 146-169, 146; Jessica Gerard, "Lady Bountiful: Women of the Landed Classes and Rural Philanthropy," Victorian Studies 30, no. 2 (1987): 183-210. Seal's article focuses on unrest between the agrarian laborer and the landed elite; however, I argue that Mary Anne's presence as a wealthy, upstanding middle-class member of the community also made her feel obligated to help the Wincobank villagers due to the reciprocal duties of the middle and lower classes.
} 
The WTAS's leadership also set it apart from other societies as it was the women in the family who ran it: mainly Mary Anne Rawson and her daughter Lizzie. Unlike urban teetotal societies, which were predominately run by male officers, there is no evidence that Mary Anne's brother, Edmund Read, was involved. ${ }^{495}$ A past study of Sheffield's temperance movement even argued that the "most active" middle-class women involved in the society were family members of men who participated in the association. ${ }^{496}$ Edmund Read's absence from the Sheffield Temperance Society may explain why the Rawson women were not members of the town's organizations and instead chose to create their own local society.

The Rawsons' engagement with officers of the Sheffield Society for Promoting Total Abstinence suggests that it was not any moral or intellectual differences that prevented the family from participating in Sheffield's teetotal societies. Family correspondence shows that members of the town's organization like Edward Smith and Mr. Harmer Smith contributed to the WTAS meetings as chairmen and speakers. ${ }^{497}$ This information suggests that the Rawsons were willing to work with individuals who were active in the city's temperance movement, even if they were not personally members of these societies. Mary Anne and Lizzie's management of the WTAS indicates that they did not allow Edmund's lack of participation to stop them from engaging in a cause they believed in. By establishing the WTAS, Mary Anne and her family could personally supervise the society and directly aid members of their community. The unorthodox leadership of the WTAS also explains why they focused on teetotal events as teetotal teas and festivals were the purview of middle-class women within the temperance movement.

\footnotetext{
${ }^{495}$ Lewis Shiman, 182; "Temperance Society," Sheffield Independent, August 6, 1831, BNA; "The Total Abstinence Society," Sheffield Independent, August 6, 1842, BNA.

496 Reid, "Middle-Class Values and Working-Class Culture in Nineteenth-Century Sheffield," 404.

${ }^{497}$ Lizzie Rawson to Catherine Read, April 17, 1841, MAR, MD 5698, SCA.
} 
Furthermore, the family opened up their house and property for their charitable endeavors, including the WTAS. ${ }^{498}$ Other Sheffield teetotal societies used public venues like the infirmary, the music hall, and the Friends Meeting House, illustrating the exceptional nature of the Rawsons locating their temperance activism in their home ${ }^{499}$ I suggest that the Rawsons utilized their private property as a way to normalize women's leadership positions by hosting its events in a space that acknowledged the domestic authority of middle-class women. The Rawsons blended the public and private by using their home, Wincobank Hall, to host public teetotal events that highlighted the pleasures inherent in a respectable, sober domestic lifestyle.

Located three miles outside of Sheffield, Wincobank Hall was a three-story home that served as the social, charitable, and domestic epicenter of the Rawsons' lives. Wincobank Hall was emblematic of the family's respectability and status as it featured a dining room, drawing room, library, housekeeper's room, butler's pantry, seven bedrooms, nine dressing rooms, and servants' quarters. The house was surrounded by eighteen acres of fields which included multiple kitchen gardens, fruit trees, and a vinery. During the 1840 s, when the WTAS met, renovations to the house and grounds further readied it for its purpose as a domestic seat and meeting place. In April of 1841, a boys' school was built behind Wincobank Hall abutting the family gardens. And, sometime in the 1840s, a "northern extension" and a "large bay-drawing room window" were added to the house. ${ }^{500}$ The construction of the boy's school and additions to the house increased the number of guests the Rawsons could receive in their home and property. These

\footnotetext{
${ }^{498}$ Alison Twells also argued that Wincobank Hall was the center of the Rawsons' charitable enterprises in her book, The Civilising Mission and the English Middle Class.

499 "Lecture on Temperance," Sheffield Independent, October 12, 1844, BNA; “Temperance Soiree," Sheffield Independent, January 6, 1849, BNA.

500 "Advertisement for Auction of Wincobank Hall," October 18, 1887, SSC, SSC 792 , SCA; Taylor, "Life of Mary Anne Rawson," 12; Grace Corbett, Richard O' Neill, and Andrea Burgess, "Archeological Excavations at Wincobank Hall, Sheffield," Transactions of the Hunter Society 27 (2018): 29-44. This study also suggests that the addition in the 1840 s was to incorporate visitors.
} 
features illustrate the Rawsons' status and demonstrate how they augmented their home to make it more suitable as a domestic and charitable space.

Rappaport's four categories of women's involvement in temperance-- money, time, space, and food - illuminate how middle-class women like the Rawsons played an active role in the teetotal movement. The correspondence between Mary Anne Rawson's daughter, Lizzie, and her cousin, Mary Eliza Wilson, and her aunt, Catherine Read, reveals insights about the WTAS and role of middle-class women and teetotal events in the temperance movement. Lizzie's letters evidence the close familial bonds between the Reads and the Wilsons and provide a rich account of the exceptional and mundane elements of Lizzie's life including news about family members, pets, villagers, and local events. They also demonstrate that the families shared a zeal for philanthropy.

The Rawsons and Wilsons fostered a sense of charitability and activism in their children, as their mother, Elizabeth Read, had done for them. ${ }^{501}$ Letters between cousins Lizzie Rawson and Mary Eliza Wilson document the financial contributions they gave to charitable works. For instance, Lizzie wrote to Mary Eliza of her donations to the teetotal fund, mentioning when she had saved "a pence" and " 8 d." for "Teetotal money." 502 These letters also illustrate the role of kinship networks in the Rawsons' teetotalism.

Lizzie also used her kinship ties to encourage her cousins to donate to their charitable endeavors at Wincobank Hall. She urged Mary Eliza to send the donations she was saving for the "Woodside chapel" so that she and her sister could start collecting for the construction of Wincobank chapel and offered to send them a "little subscription book" in which to record their

\footnotetext{
${ }^{501}$ See Alison Twells, The Civilising Mission and the English Middle Class, 88.

${ }^{502}$ Lizzie Rawson to Mary Eliza Wilson, [Suggested before 1841], MAR, MD 5698, SCA; Lizzie Rawson to Mary Eliza Wilson, April 27, [Suggested before or in 1841], MAR, MD 5698, SCA; Lizzie Rawson to Mary Eliza Wilson, Wincobank, January 7, 1841, MAR, MD 5698, SCA.
} 
collections. ${ }^{503}$ Lizzie's reference to the subscription book shows that she was familiar with the methods of record keeping for charitable giving. This indicates that Lizzie's family fostered the standard practices used in charitable money-raising during her youth to prepare her for her future role as a benefactor.

Lizzie's suggestion that Mary Eliza and her sister collect for Wincobank also illustrates how family networks used filial bonds to gather support for causes. This example shows that the family preserved their familial connections and kept the Wilson children engaged in the Read's charitable interests through their visits to Wincobank Hall and family correspondence. Moreover, it demonstrates that these connections provided even young, unmarried women with the opportunity to support charities outside of their own neighborhoods.

Lizzie Rawson's letters also documented how she contributed her time to teetotalism. The letters often exhibited Lizzie's pride in being able to help in the family's teetotal society. For instance, Lizzie wrote to her aunt, Catherine Read, that she "was very busy" preparing "medals" for one of the teetotal events. ${ }^{504}$ This was not an isolated case either. Another of Lizzie's letters boasted to her cousin Mary Eliza that she had "made the greater part [of a] smaller flag" that would be carried in a teetotal procession. ${ }^{505}$ Both examples denote that Lizzie devoted her time and energy to the family society. Furthermore, they show that she was entrusted with making materials that would represent the society to the public, as medals and banners were physical representations of the club.

Lizzie's sewing, moreover, was particularly relevant as it revealed that Lizzie used her domestic skills to serve the society. Much of women's work in nineteenth-century associations

\footnotetext{
${ }^{503}$ Lizzie Rawson to Mary Eliza Wilson, [Suggested before 1841], MAR, MD 5698, SCA.

${ }^{504}$ Lizzie Rawson to Catherine Read, April 17, 1841, MAR, MD 5698, SCA.

${ }^{505}$ Lizzie Rawson to Mary Eliza Wilson, Wincobank, May 31, ND, MAR, MD 5698, SCA.
} 
utilized women's "natural" domestic roles to legitimize their participation in public associations. One of women's responsibilities in eighteenth- and nineteenth-century domestic codes was to prepare clothes and linens for the family. The use of domestic skills justified women's participation in public matters since women should employ them for the benefit the community, particularly the lower classes. ${ }^{506}$

Participation in charitable causes like teetotalism also required interaction with the lower classes, especially for the Rawsons whose primary aim in philanthropy was helping the Wincobank villagers. Lizzie's engagement in the WTAS also gave her experience fulfilling her duties to the less fortunate around her. Lizzie served the family's teetotal society by encouraging members of the community to attend the WTAS's events. She was entrusted with the task of promoting the society amongst the Wincobank villagers and was therefore seen as a suitable representative of the society despite her youth. ${ }^{507}$ This role required her to speak with members of the community to beseech them to attend these events. This was certainly a daunting task for a young woman, as one of Lizzie's letters showed.

Lizzie's experience demonstrates that despite the rise of teetotalism in the 1840s, it was still not a popular cause with the Wincobank villagers. An anecdote from her correspondence reveals that others' reluctance to engage with teetotalism sometimes forced her into awkward encounters. Lizzie wrote that during a journey "up the Hill to try to persuade some people to come to the meeting," she met Joseph Sellars. Upon seeing him, she asked if he would be coming to WTAS' event that evening-- an invitation he frankly refused. Surprised by his tone

\footnotetext{
${ }^{506}$ Karen Hagemann, "Female Patriots: Women, War, and the Nation in the Period of the Prussian-German AntiNapoleonic Wars," Gender and History 16, no. 2 (2004): 397-424, 411; Katherine Aaslestad, "Patriotism in Practice: War and Gender Roles in Republican Hamburg, 1750-1815," in Gender, War, and Politics: Transatlantic Perspectives 1775-1830, eds. Gisela Mettele and Jane Rendall (New York: Palgrave Macmillan, 2010), 227; Twells, 'Let Us Begin Well at Home', 27, 34, 37; Twells, The Civilising Mission and the English Middle Class, 3, 105, 113; Linda Colley, Britons: Forging the Nation, 1707-1837 (London, Yale University Press), 264-267.

${ }^{507}$ Lizzie Rawson was sixteen years old in November 1844.
} 
and reluctance to speak with her, Lizzie pressed him to reconsider by tempting him with the promise of "a very fine speaker." This bait, however, was not enough to satisfy Joseph, who replied that he would have gone 'if there was going to be a good gospel sermon preached...but not as it is.' This stipulation is interesting, as it shows that Joseph likely qualified as an "upstanding" member of the poor. At the very least, he appeared to be open to the Read's religious charitable work-- it was specifically the teetotal message that he rejected. Undaunted by his reply, Lizzie assured him that there would most likely be a religious message in the speech, "for there often was... in the Middle of the Teetotalism." ${ }^{508}$ Despite her logic, Joseph still refused to attend.

This exchange demonstrates how Lizzie's sense of obligation towards the villagers compelled her to take on a difficult task. To fulfill her role and ensure the happiness and prosperity of the lower classes around her, she had to use her reason and rhetorical powers to persuade others against their hesitations or biases. Though it may seem like Joseph Sellars was merely put out by being harassed by a young girl, his aversion to teetotalism was deeper than mere annoyance at Lizzie's badgering. The letter reveals that Joseph also refused to speak about this with Lizzie's aunt, Emily Read-- the woman most-involved in the family's parochial charity and well-known by the Wincobank villagers. ${ }^{509}$ This caveat offers an opportunity to reexamine class relationships and middle-class philanthropy in Sheffield.

Joseph Sellars serves as a personification of lower-class resistance to middle-class authority in nineteenth-century Sheffield and the separation between the middle classes and the lower classes. This rift stemmed from the physical and cultural separation of the lower classes first into industrial villages and later into working-class slums and the middle classes’

\footnotetext{
${ }^{508}$ Lizzie Rawson to Mary Eliza Wilson, Wincobank, November 27, 1844, MAR, MD 5698, SCA.

509 Ibid.
} 
association of lower-class pastimes and sociability like the pub with immorality and disreputableness. Moreover, the prevalence of radical lower-class ideologies like Chartism also created tensions that fed the middle classes' desires to make respectable, middle-class culture alluring and amenable to lower-class audiences-particularly men.

Chartists ensconced the increasing lower-class hostility to the industrial elite and the social and economic conditions of the town from the late 1830s to mid-1840s. Chartism was not only the largest threat to the traditional order in Britain —in Sheffield it also represented a combination of its various radical cultures like Jacobinism, New Connexion Methodism, and radical working-class demands for universal male suffrage. This unrest came to a head in the summer of 1839 with Chartists espousing a rhetoric of the need to displace the current leadersthe town's industrial elite — and staging rallies that resulted in the arrest of several leaders and activists. ${ }^{510}$ Moreover, the town's reputation of ambiguous social stratification created a sense of ambiguous social position and a corresponding alarming rate of independence amongst the lower classes. For example, in Sheffield's cutlery trade, 'little mester[s]' confounded the stable division between master and worker so characteristic within the Industrial Revolution's narrative by being able to simultaneously work in another cutler's small workshop and establish his own enterprise with apprentices working under him. ${ }^{511}$

Joseph Sellar's example refutes any suggestions of an inherently repressive relationship between middle-class philanthropists and lower-class beneficiaries. His responses to Lizzie proved that he successfully rejected the family's teetotal message and did not feel pressured to accept the Reads' values due to fears that the Reads would retaliate or deny him aid or favor. Instead, this exchange demonstrates that class relationships were never a constant- - they were

\footnotetext{
${ }^{510}$ Price, 37, 42-3.

${ }^{511}$ Twells, The Civilising Mission and the English Middle Class, 58-60, 101, 145.
} 
shaped by individual circumstances and local culture and relied upon the interplay between "reciprocity, dependence, and resistance." ${ }^{512}$ This awkward encounter illustrates how the sense of maternal care and solicitude that drove the Rawsons' teetotal work could create awkwardness between the family and the Wincobank villagers and reifies lower-class individuals' agency within middle-class philanthropic ventures. Mary Anne could do her best to "domesticate" lower-class men by teaching them to grow hyacinths in empty ale glasses, however, as Joseph Sellars showed, her attempts to repurpose symbols of drink for beautiful, domestic purposes could not force her ideals and practices onto unrelenting opponents or uninterested parties. ${ }^{513}$ Regardless of potential unpleasant encounters with unenthusiastic individuals, the Rawsons remained passionate about promoting these events.

Convincing people like Joseph Sellars to come to the meetings was important because the WTAS used these events as outreach opportunities. The WTAS sponsored teetotal events such as teetotal teas and festivals that advocated the benefits of sobriety. ${ }^{514}$ The Rawsons' meetings provided sources of entertainment and educated the public on the importance of sobriety. The key components of the WTAS included teetotal speeches, processions, and teas.

Teetotal speeches were a crucial part of both teetotal teas and festivals that also serve as an example of the use of space in teetotal events. Despite its status as a small family-run association on the outskirts of Sheffield, the WTAS managed to feature speeches by a few

\footnotetext{
${ }^{512}$ Hans Medick and David Warren Sabean, "Introduction," in Interest and Emotion: Essays on the Study of Family and Kinship, eds. Hans Medick and David Warren Sabean (Cambridge: Cambridge University Press, 1984), 3.

${ }^{513}$ See Twells, The Civilising Mission and the English Middle Class, 102; Taylor, "Life of Mary Anne Rawson," 15. See also, Smith.

${ }^{514}$ The Rawson's hosted teetotal teas that featured a feast on their property followed by a meeting in the Boys' School and teetotal festivals that included a procession, teetotal tea, and a meeting. Lizzie's letters suggest that these teetotal meetings used the same elements as other teetotal societies, particularly in Yorkshire, featuring the use of processions, prayers, hymns, speeches, and feasts. Taylor's study specified that the society used specially written temperance hymns to the tunes of "Old Folks at Home" and "Nelly Bly." Rappaport, 1006; Lizzie Rawson to Mary Eliza Wilson, Wincobank, May 31, ND, MAR, MD 5698, SCA; Taylor, "Life of Mary Anne Rawson," 15.
} 
famous teetotal speakers. These prominent guest lecturers served an important role within the events: attracting guests. The opportunity to hear famous men and the stories of those who had dedicated their lives to teetotalism was a crucial aspect of these events' allure. Lizzie's letters addressed several prominent men who were invited to speak at the WTAS. Her letters elucidate the role of these teetotal speakers in the broader movement.

James Teare, Edward Grubbe, and John Hockings were all famous working-class teetotal speakers who performed at the WTAS' teetotal teas and festivals. Though it may seem strange that they were of a different social class than the Rawsons, these speakers were indicative of the large predominance of the working classes active in promoting teetotalism. Despite their class differences, these men shared nonconformist ideals and worldviews with the family which united them in a mission to address drunkenness. Nevertheless, the Rawsons did not merely value these speakers because they shared the same values; the WTAS also used them as incentives to draw in audiences.

These men were prominent figures in the teetotal movement who traveled from town to town performing at local societies throughout Great Britain. Their celebrity corroborates the WTAS's legitimacy: their willingness to speak at this local, family-run society proves that they did not deem it a waste of their time - they considered it as a valid part of the temperance movement. Each of these men illustrate how societies like the WTAS used teetotal speakers to inspire their audiences to renounce alcohol. John Hockings' career serves as an excellent example of the allure of these teetotal speakers. Hockings was a renowned teetotal speaker from Birmingham, known for captivating the crowd with his use of humorous anecdotes embellished 
from his own life. ${ }^{515}$ In this way, these men served as sources of entertainment that subtlety educated their audiences and shared important lessons.

Traveling teetotal speakers like James Teare, Edward Grubbe, and John Hockings demonstrate how charitable causes generated networks that connected like-minded individuals across the country. The WTAS gave Mary Anne and Lizzie Rawson the opportunity to meet with prominent figures within teetotalism. It therefore allowed them to participate in the wider movement by hosting these men to speak in their local society centered around their home and to use their ideas as ammunition against drunkenness in their community. The WTAS proves that women were not limited to domestic concerns — rather, their societally sanctioned roles legitimated their interest in public matters like teetotalism and enabled them to forge ties with influential thinkers such as these teetotal speakers.

Lizzie's letters, which attest to the quality of these men's speeches, also support the notion that these speakers served as an attraction. One letter particularly discussed a meeting where Mr. Addelshaw, a famous proponent of total abstinence from Bolton-le-Moors, came to speak. ${ }^{516}$ In her letter, Lizzie expressed her anticipation to hear Addelshaw speak and her irritation that three teetotalers from Sheffield --"rather poor vulgar speakers"-- took up so much time with their speeches before he could address the audience. ${ }^{517}$ It appears that Lizzie was not the only one waiting to hear Mr. Addelshaw as her letter disclosed that her aunt, Emily, had to tell the chairman to skip over other teetotalers' speeches to allow suitable time for Addelshaw's

\footnotetext{
515 Harrison, 129.

516 "Local intelligence," Westmoreland Gazette, November 1, 1856, BNA.

${ }^{517}$ Lizzie Rawson to Mary Eliza Wilson, May 31, [Suggested 1844], MAR, MD 5698, SCA. In this instance, Lizzie's use of the term vulgar does not denote unrespectable, lower-class conduct, but that their speeches were less interesting or impressive than teetotal speakers like Addelshaw's.
} 
address. ${ }^{518}$ This anecdote demonstrates the Read sisters' authority in the society and supports my argument that a crucial role of these speakers was drawing in an audience which could be a useful means to overcome the reluctance of individuals like Joseph Sellars. From Lizzie's letters, it appears that the Rawsons were successful in their use of speakers to consistently draw in an audience.

Lizzie's letters often reflected on the great attendance at these events. There were several mentions of well-attended events, such as meetings where "the school [was] quite filled," processions of "eighty two teetotalers," and even more women and children, and teetotal teas that served "nearly all the teetotalers and more than one hundred other people." ${ }^{519}$ The large turnout was important not just from a social point of view, but also from an evangelical one. In one letter, Lizzie shared her excitement that a meeting's message had been especially affecting, inspiring "many people" to make a pledge of total abstinence after the meeting. ${ }^{520}$ This comment illustrates another crucial point; people were not just attending these events-- the events themselves convinced more people to sign the pledge of total abstinence. Teetotal events like processions also provided an opportunity for teetotalers to publicly demonstrate their beliefs to their community while promoting sobriety.

\footnotetext{
${ }^{518}$ Gendered ideas about women's role in the public sphere restricted most women from speaking publicly. This explains why the Reads/ Rawsons relied on a male chairman to serve as the officiator during teetotal speeches. It is worth noting that Emily directed the chairman on how to respond to this issue-- the chairman did not take responsibility for this decision himself. This suggests that female family members oversaw these events, even if they had to allow men to perform the society's traditionally public roles. See Midgley, Women Against Anti-Slavery, 5960; Sirpa Salenius, An Abolitionist Abroad: Sarah Parker Remond in Cosmopolitan Europe (Amherst: University of Massachusetts Press, 2016).

${ }^{519}$ Lizzie Rawson to Mary Eliza Wilson, November 27, 1844, MAR, MD 5698, SCA; Lizzie Rawson to Mary Eliza Wilson, Wincobank, May 31, ND, MAR, MD 5698, SCA; Lizzie Rawson to Catherine Read, April 17, 1841, MAR, MD 5698, SCA. Lizzie's letter distinguishes between the men, women, and children present, suggesting that there were at least one hundred and sixty-five attending the teetotal procession and at least one hundred and eighty-two present at the teetotal tea.

${ }^{520}$ Lizzie Rawson to Mary Eliza Wilson, November 27, 1844, MAR, MD 5698, SCA.
} 
Lizzie's coverage of these processions specified the number of teetotalers who joined, individuals who carried banners, and the order that these men, women, and children processed. ${ }^{521}$ The order of these members and the selection of who was allowed to carry the banners illustrated that these organized events honored certain individuals with special positions or roles. Furthermore, the public act of demonstrating one's commitment to teetotalism served as a "public affirmation" of their pledge, making participants even less likely to backslide as doing so would prove that they had broken their word. ${ }^{522}$ In these ways, the public nature of these processions was a central aspect of their purpose and effectiveness.

Processions were also an opportunity for teetotalers to publicly exhibit their strength of numbers. These processions served as evidence of their success by demonstrating the number of supporters within the society. The WTAS's teetotal processions through the streets of the village show how its members used the public nature of processions to declare their support for this cause and the worthiness of its objectives. These events conform to Rappaport's categorization of the use of space in middle-class women's teetotal work as temperance processions dominated public streets to assert their presence physically in the community and gain supporters. Lizzie's correspondence remarked upon this aspect of her family's teetotal work and expressed her delight in the large numbers of teetotalers, women, and children who participated in the processions and guests who came for teetotal teas. ${ }^{523}$

Furthermore, the Rawsons' teetotal processions concluded at the family's home. This aspect of the WTAS's teetotal processions illustrates the true permeability of the public and private in the nineteenth century. The events began in the public sphere but ended with a teetotal

\footnotetext{
${ }^{521}$ Lizzy Rawson to Mary Eliza Wilson, Wincobank, May 31, ND, MAR, MD 5698, SCA.

${ }^{522}$ O' Leary, 108.

${ }^{523}$ Lizzy Rawson to Mary Eliza Wilson, Wincobank, May 31, ND, MAR, MD 5698, SCA.
} 
tea in the Rawsons' gardens where guests were invited to enjoy tea, coffee, and cake and hear teetotal speeches. Though these teetotal teas were public events, the Rawsons used their own estate to host these teas, allowing guests access to the areas around their home. These teetotal teas were also significant because the practice of taking tea was becoming increasingly popular as a mode of entertaining guests in middle-class homes. ${ }^{524}$ In this way, these teetotal teas were large scale renditions of more traditional private tea parties. ${ }^{525}$ The WTAS's teetotal teas show that serving teas to large crowds was not an easy task to accomplish.

Providing enough space for one's guests was a common challenge in teetotal teas and not merely a circumstance that stemmed from the Rawsons' decision to use their own property to host these events; it was also a problem for larger societies that met in public places. In fact, according to Rappaport, a chief part of these event's instructive value was to show the working classes how to maintain order and decorum while serving a large number of people. Being able to host many guests and maintain "order and regularity" was integral and necessary as a chief function of these teas was to teach the working classes "upper-class table etiquette." For this reason, Rappaport claims that these teas contained "disciplinary aspects" similar to those used by the middle classes in the "factory" and "workhouse." 526 They demonstrate that teetotal events attracted and entertained the public while simultaneously serving as an opportunity to educate and reform their audience. The WTAS's teetotal teas illustrate how the Rawsons prepared adequate space to host these large parties on their private property and serve as an example of Rappaport's final category of women's contributions to the temperance movement: serving food and drink.

\footnotetext{
${ }^{524}$ Harrison, 302.

525 Rappaport, 992.

526 Ibid., 1001, 1006, 1008.
} 
If such events have been overlooked in scholarship on the Temperance movement, the Rawsons' correspondence demonstrates that their teetotal teas were major productions that required extensive planning and management of the food, venue, and itinerary to please their guests. The Rawsons opened up Wincobank Hall to crowds of more than one hundred people for their teetotal teas. In order to accommodate everyone in this space, some quick thinking was in order. To serve their guests, Lizzie's letters show that tea was served in two shifts, sometimes seating as many as one hundred at a time. The impressive quantity of participants at these events demonstrates the need for multiple spaces as ways to entertain these crowds. On one occasion, those who were not served tea were allowed to sit in the "Boys' School" while the others ate and drank. ${ }^{527}$ At another, guests who had finished their tea walked in the gardens to "allow the rest of the guests to sit." ${ }^{" 528}$ This is a significant aspect of these events because it shows that the Rawsons welcomed the public in their gardens-- a space generally reserved for family and guests.

Lizzie's letters demonstrate that guests were not restricted to one area in the Rawsons' property but had access to multiple spaces. The proximity of the boys' school to the house and gardens suggests that the Rawsons held their tea parties where the public could see the benefits of a sober, respectable lifestyle: a large home, garden, extensive property, and the means to provide tea and delicacies for guests. By opening their home as a venue for their charitable work, these teetotal teas illustrated that the family used their domestic space to edify the public. Lizzie's pride in the success of these events is not surprising as the role of hostess was one of the duties of respectable ladies. Moreover, it was their ability to entertain and provide beautiful settings that helped the success of these events and ergo the teetotal mission. In addition to

\footnotetext{
${ }^{527}$ Lizzie Rawson to Catherine Read, April 17, 1841, MAR, MD 5698, SCA.

${ }^{528}$ Lizzie Rawson to Mary Eliza Wilson, Wincobank, May 31, ND, MAR, MD 5698, SCA.
} 
crafting an alluring atmosphere, teetotalers strategically used beautiful objects endowed with symbolic importance to attract converts and retain followers.

Teetotal regalia like cards, ribbons, medals, and banners were physical representations of the organization and teetotalers' identities. These items served as a way to establish a spirit of solidarity amongst teetotalers because each object symbolized their unity of purpose and physically represented their personal transformation. The latter point was especially important considering their separation from their past lives and the possible hostility they faced from members of their community who continued to enjoy drink. Moreover, these symbols used aesthetics to endow the object with value and honor their cause.

Symbolic objects were an important means of recognizing and sacralizing the individual's transformation, as shown in the family's letters. Pledge cards and ribbons served as reminders of the individual's promise to abstain from consuming and serving alcohol. Moreover, they were physical signs of one's adherence to their promise. Those who broke their vows were expected to come forward and admit their breach of promise by returning the card and ribbon to their teetotal society. ${ }^{529}$ In this way, the card and ribbon served as an outward sign of an inward change or personal principle. Its presence served as a physical indicator of their commitment to the cause and a motivating force to stay true to their pledge. Moreover, the overt ceremonial nature of these items denotes the role of ritual, display, and beauty within teetotal societies. Teetotal societies also utilized medals in order to establish a feeling of solidarity whilst simultaneously marking these events as special occasions by using these items to add to the ambiance and festivity of the events. It is clear from Lizzie's letter that the medals were painstakingly crafted and esteemed as special components of the celebration as Lizzie carefully

\footnotetext{
${ }^{529}$ Edmund Read to Rebekah Wilson, The Mills, March 5, 1846, MAR, MD 5698, SCA. Edmund reminded his niece that anyone who "break[s] [their pledge must acknowledge their failure by] returning the card and ribbon."
} 
described her choice-- a "very large [medal] ... with a very beautiful blue ribbon \& a white satin rosette on [it]. ${ }^{" 530}$ While it may seem superficial that she was concerned with its beauty, as Harrison pointed out, these symbols were crucial methods of identification and served as rewards for loyalty to their pledge. ${ }^{531}$ For this reason, it was likely important that the medals were aesthetically pleasing, as it would be fortuitous if they were both envied and appreciated as a reward for moral victory and personal sacrifice.

Even the embellished banners carried in teetotal processions were material objects endowed with symbolic importance. These banners represented their society and as such colors and embellishments were used to draw the community's attentions to and show the society's commitment to their cause. According to Lizzie's letters, the WTAS had two banners. One was a "very large flag [of] white calico with a broad border of blue [and] blue fringe [on the bottom with blue letters in the middle that spelled] Wincobank Total Abstinence Society [surrounded by a] large wreath of oak leaves." The other was a "smaller...white [one with] a border fringe of yellow [that said] Tee-totalism for ever in yellow letters in the middle [with] a bunch of flowers,.. blue fringe, [and] streamers" on top. ${ }^{532}$ The expressive detail that Lizzie provided in describing these flags to her cousin underscores the importance of the materials selected and the organization of the piece. These examples illustrate the thought and attention dedicated to teetotal events' settings and the paraphernalia used within them. Though past scholarship has neglected them as unworthy of serious study, the beauty, grandeur, and pomp of teetotal events were crucial aspects of middle-class women's roles in the teetotal movement and an important part of the building and sustaining of the temperance community.

\footnotetext{
${ }^{530}$ Lizzie Rawson to Catherine Read, April 17, 1841, MAR, MD 5698, SCA.

${ }^{531}$ Harrison, 132.

${ }^{532}$ Lizzie Rawson to Mary Eliza Wilson, Wincobank, May 31, ND, MAR, MD 5698, SCA.
} 
Teetotal events used respectability, finery, and aesthetically pleasing objects to draw individuals into the movement. Lizzie's letters demonstrated that even though teetotalism was not widely accepted, these events were well-attended. I hypothesize that elegant food, polite society, entertaining famous speakers, and beautiful regalia made these teetotal teas effective at Wincobank Hall. It is therefore understandable that Lizzie Rawson was especially attracted by the pomp, circumstance, and novelty afforded by teetotal events. She was drawn to the ways it allowed her family to host guests, serve tea, and have prominent and well-known temperance advocates speak. Though her dedication to the cause cannot be denied, as proven by her diligent collection of money and contribution of labor, she was also captivated by the opportunity to partake in respectable sociability at these teetotal events.

\section{Conclusion}

Nineteenth-century middle-class conceptions of the home as a domestic haven influenced the temperance movement as advocates—especially teetotalers who championed abstinence from all forms of alcohol—sought to educate the public on the detrimental impact of alcohol consumption. As this chapter has shown, teetotalers placed special emphasis on the importance of reforming the lower-class home in both urban slums and rural villages. Temperance advocates were particularly distressed by how alcohol endangered lower-class families.

Contemporary fears about working-class women and their children's vulnerability due to the proximity of alcohol to their family and social lives prompted elite women to view their help as morally and practically necessary. Their gendered, domestic roles placed them as experts on matters of the home and the family, which proved particularly important due to teetotalism's espousal of domesticity and sober sociability as superior to pub culture. Teetotal societies particularly encouraged practices where family and friends gathered in the home to take tea 
together, a practice synonymous with respectable, domestic conventions at this time. Middleclass women played a vital role in hosting teetotal events which fostered friendships and reinforced individual commitment to the cause through symbolic cards, medals, and banners. These events were crucial elements of temperance activism, especially the teetotal movementnot frivolous affairs.

Rappaport asserted that the public nature of these temperance events contributed to their purpose and effectiveness within the movement. She argued that these tea parties served as "a promotional occasion" or "advertisement...that legitimated certain commodities while denigrating others as irrational, wasteful, and harmful." 533 To expand upon this point, I propose that these teetotal events were advertisements and incentives for teetotalism's message and goals that used cake, tea, and polite conversation to demonstrate how the society could improve individual's lives and help them to create a new, respectable social world for themselves.

Like Rappaport, I argue that part of the appeal of these teetotal events, was the use of respectable society to enchant people to swear off alcohol and engage in alternate methods of sociability. These events provided much needed pastimes and opportunities to gather likeminded people and represented a break in the everyday routine that improved the audiences' lives. Thus, a crucial part of the teetotal movement's outreach and retention efforts entirely depended on women's provenance as domestic authorities and connoisseurs of sociability. This chapter utilized Rappaport's four categories of money, food, space, and time to highlight the Rawsons' engagement in the temperance movement and the importance of the events hosted by their small, family-run teetotal society, the WTAS.

\footnotetext{
${ }^{533}$ Rappaport, 993.
} 
Middle-class women's work in teetotal events were an integral part of the temperance movement that has been largely neglected in scholarship. My case study shows that women were active in teetotalism through their sponsorship of teetotal events, which played important educational and promotional functions in spreading the teetotal message. The Rawsons' example reveals how these women used their own home as a vehicle to impart the values of sobriety and respectability to the villagers they invited to their events. Though the use of their heavenly home, Wincobank Hall, may be unique, it demonstrates how middle-class women integrated ideas of the public and private to engage in activism and philanthropy. Ultimately, the WTAS's example proves that women like Mary Anne and Lizzie Rawson supported the teetotalism movement by sharing their home as they performed societally sanctioned domestic roles hosting teetotal events. 


\section{Chapter 5}

My Brother's Keeper: Conflicts between Personal Ambition and Family Strategy in NineteenthCentury Family Businesses

Family conflicts offer a vantage point into the tensions inherent in trying to balance one's personal ambitions and the family network's strategy. This struggle was especially evident during periods of transition or change in the family business. The Reads' quarrels reveal how uncertainty and disappointed hopes led individuals to reassess their position within the family network. In these situations, family members schemed about methods that would simultaneously support their personal ambitions and promote the wider family network's goals—or plotted ways to redefine family strategy to suit their personal ambitions. The Reads' family conflicts in 1846 and 1860 both centered around proposed changes to the company's leadership. These cases demonstrate that personal ambition could challenge filial obligations and that when it did, individuals had to reconsider the utility of honoring their duties to their extended kin. During these episodes, family loyalty came into question and each side had to ask themselves, "Am I my brother's keeper?"

The Reads' family network demonstrates that in some ways the ties between extended family members were even more circumstantial than the biblical allegory of Cain and Abel. Just as in this story, which is arguably the first example of family conflict in the Western Christian narrative, the Reads and Wilsons had reason to ponder what they owed each other and how far such loyalties should be carried. What was the limit of an uncle's responsibility to his deceased brother's family or a husband to his wife's brother? In times of prosperity, family members celebrated and embraced their extended kin as "affectionate" uncles, nephews, nieces, brothers, 
and sisters. In times of economic distress, confusion and strife, these links became more tenuous and family networks relied even more on female family members as negotiators and referees between parties. As this chapter will show, the weakening of female ties and the strains of personal ambition in competition with family strategy placed the family network in danger.

\section{Kinship, Family Conflicts, Female Negotiators, and Masculine Roles in the Household}

The Reads' quarrels can only be fully understood in the context of the broader historiography on feuds, family conflicts, women's roles as negotiators of familial tensions, and the connection between middle-class masculinity and men's provisionary roles. Each of these subjects played a crucial role in the Reads' quarrels in 1847 and 1860 and offers insights into family dynamics and the underlying issues within these conflicts. Though the Reads' examples never completely devolved into a violent or self-destructive family feud, scholarship on family feuds demonstrates how others have analyzed interfamilial tensions and blood feuds.

Recent scholarship on family feuds offers important insights into the role of kinship in these events. Osvaldo Raggio's study of early modern Liguria argued that analyzing kinship illuminates the wider structure of society because families played political, economic, and fiscal roles that established interpersonal relationships and dictated how individuals treated each other. ${ }^{534}$ In order to understand the true context of feuds, one had to study the goals and incentives of these groups and their members to reveal what could be gained through their alliances. Altina L. Waller's study of one of the most infamous family feuds of the nineteenth century--the Hatfields and the McCoys - demonstrated this point by proving that even in legendary feuds such as this the two sides were not strictly based on blood lines. Rather, people were drawn into networks not only by family and marriage ties but also by how they perceived

\footnotetext{
534 Osvaldo Raggio, Feuds and State Formation, 1550-1700: The Backcountry of the Republic of Genoa, trans. Matthew Vester (Cham, Switzerland: Palgrave Macmillan, 2018), xvi, 31.
} 
such relationships would benefit or weaken them. In other words, factors such as "common" economic and professional "interests" influenced conceptions of "family loyalty." "535 This illustrates that individual's circumstances, ambitions, and needs impacted notions of family loyalty. As Sabean's study of eighteenth and nineteenth-century Neckerhausen showed, failure to uphold one's contributions to the family network often created family conflict.

Sabean's work demonstrated that familial relationships were built upon ideas of exchange or reciprocity. For instance, the quarrels between Leonard Weiler and his stepson, Johan George, over access to tools revealed an accepted "system of exchange" where children traded manual labor on their parent's land for access to resources, wages, or property depending upon their parent's age. ${ }^{536}$ In addition to demonstrating that failure to uphold one's role in this relationship led to interfamilial tensions, Sabean's work also stressed the limits of family loyalty by pointing out that even family members expected to receive payment for their work. ${ }^{537}$ This concept also offers revolutionary insights into marriage ties and familial obligations. Sabean noted that families used marriage to try to establish cooperative, beneficial alliances. These ties created "a set of social relationships which would structure and make possible a lifetime of fruitful exchanges [ - not because] anyone had a particular claim on an in-law, but [because they were entitled to]... consideration and cooperation." ${ }^{538}$ Affinal ties (or in-laws) therefore were not bound by any unbreakable bonds, but did consider themselves entitled to aid and solicitude. As such, there were expectations of reciprocal services and mutual benefits which must be met to

\footnotetext{
${ }^{535}$ Altina L. Waller, Feud: Hatfields, McCoys, and Social Change in Appalachia, 1860-1900 (Chapel Hill: University of North Carolina Press, 1988), 11, 77, 80-1.

536 Sabean, Property, Production, and Family in Neckarhausen, 278.

${ }^{537}$ Ibid., 284, 315.

${ }^{538}$ Ibid., 418-9.
} 
secure familial harmony within the natal and marital families. Women played an integral role in the restoration of familial ties during family conflicts.

Many studies of aristocratic women's roles in their kinship networks demonstrate how they utilized their affectionate relationships with natal and marital family members to act as mediators between both parties in quarrels. Studies of aristocratic women and their family correspondence reflect the same points and practices of the middle-class women studied in this project. As Clarissa Campbell Orr pointed out, "monarchy in the early modern period was... a dynastic, family business." 539 Just as Mary Anne and Catherine wrote to further their family's interests in Read \& Co., aristocratic women took responsibility for seeking their family networks' interests. In Magdalena Sanchez's study of Catalina Micaela's letters to her husband Carlo Emanuele I, for example, she demonstrated that Micaela used her affectionate concern as a devoted wife to remind him of his husbandly duties and to serve as a go-between who represented her father's interests to her husband. ${ }^{540}$ Similarly, Adelina Modesti's case study of Margherita de' Medici Farnese provides evidence of women's integral "diplomatic" role in resolving the "political tensions... that could arise between natal and marital families."541 Similarly to women's use of their affective, domestic roles within the family network to navigate tensions and restore harmony, middle-class men's professional identities served as a crucial component of their gendered roles as husbands and fathers.

\footnotetext{
${ }^{539}$ Clarissa Campbell Orr, Queenship in Europe, 1660-1850: The Role of the Consort (Cambridge: Cambridge University Press, 2004), 1.

${ }^{540}$ Magdalena S. Sanchez, 'Lord of My Soul': The Letters of Catalina Micaela, Duchess of Savoy, to Her Husband, Carlo Emanuele," in Early Modern Habsburg Women: Transnational Contexts, Cultural Conflicts, Dynastic Continuities, eds. Anne J. Cruz and Maria Galli Stampino (Farnham: Ashgate, 2013), 79, 80-1.

${ }^{541}$ Adelina Modesti, "Margherita de' Medici Farnese: A Medici Princess at the Farnese Court," in Medici Women: The Making of a Dynasty in Grand Ducal Tuscany, eds. Giovana Benadusi and Judith C. Brown (Toronto: Center for Renaissance and Reformation Studies, 2015), 231-2. Duchess Margherita took the initiative for seeking her son, Ranuccio II's, interests by using her affectionate, familial ties to her brother, Cardinal Giovan de' Medici, and notions of reciprocal respect to convince him to protect her son's status as a duke of Parma and Piacenza in Grand Duke Ferdinand's court.
} 
Though most studies of nineteenth-century middle-class family life focus on the role of women as wives and mothers, recent works on men's roles in the family reveal that men's household roles depended upon their status as income-gatherers and managers. ${ }^{542}$ Men's domestic roles as providers of the family's resources meant their fatherly and husbandly duties demanded they protect the family from want. ${ }^{543}$ Karen Harvey argued that middle-class men and women engaged in two different, gendered definitions of housekeeping. Whereas women's housekeeping involved attention to household chores, men's "keep[ing] house" meant practicing “oeconomy” by owning property and assuming control over a household. ${ }^{544}$ Similarly, John Tosh's study argued that middle-class conceptions of masculinity hinged upon a man's abilities "to establish a home, to protect it, to provide for it, to control it, and to train its young aspirants to manhood." 545

As these points show, nineteenth-century middle-class norms reinforced men's dedication to their families. The professional did not outweigh the domestic, particularly in the model of evangelical "Christian masculinity," according to which manliness required "enjoy[ing] domestic life and willingly tak[ing] responsibility for children." ${ }^{546}$ Fathers used their loving bonds with their children to direct and guide them by couching their advice or demands as coming from a place of love and signing themselves as their "affectionate father." 547 These combined domestic and professional responsibilities enabled middle-class men to assert their capacity for "selfgovernance," which in turn, proved their right and ability to participate in the public sphere-a factor so important that the role became synonymous with men's civic duties by the end of the

\footnotetext{
${ }^{542}$ Bailey, 173; Claudia Nelson, "Wives and Husbands," in Family Ties in Victorian England (Westport, Conn: Praeger Publishers, 2007), 29-30.

${ }^{543}$ Bailey, 173.

${ }^{544}$ Harvey, 532-3, 535-6.

545 Tosh, A Man's Place, 4, 107-8.

${ }^{546}$ Hall, "The Sweet Delights of Home," 57.

${ }^{547}$ Barker, 126.
} 
eighteenth century. ${ }^{548}$ The importance of these qualities can be further understood by reviewing how well the figures in this case study upheld these characteristics.

These family conflicts demonstrate how the Reads' manliness was called into question when Uncle John and Edmund failed to fulfill many-- if not all-- of these requirements. Both Uncle John and Edmund faced financial problems, did not produce children, held precarious professional positions, and had insecure ties of ownership to the house at the Mills. ${ }^{549}$ In contrast, Wilson's domestic and professional life represented a much stronger model of nineteenth-century masculinity. He had derived an abundance of wealth from his cotton-spinning mill in Nottingham, had eight children, would own two profitable businesses by 1847 , and had three homes throughout his lifetime. ${ }^{550}$ By creating a dichotomy between the Reads' failures and Wilson's successes, these quarrels illuminate the importance of professional and domestic responsibilities in men's reputations.

There are two commonalities between the quarrels in 1847 and 1860: new leadership in the family company called to question certain individual's roles in the family network and business's future. Though scholars used to assert that the modern period represented the end of the extended family's influence and the rise of individuality, capitalism, and the nuclear family, my case study provides further evidence of the enduring influence of kinship networks in the nineteenth-century. ${ }^{551}$ Despite the rise of capitalism and individualism, in both of these quarrels,

\footnotetext{
${ }^{548}$ Harvey, 532-3, 535-6.

${ }^{549}$ As this chapter will show, Uncle John and Edmund's ties to the company emasculated them in many ways because the company's financial problems and Edmund's insecure position in the company complicated their status as provisioners and householders. Uncle John lost the family company when he went bankrupt in 1846 and Edmund never attained a prominent position in it. Uncle John lost his home after his bankruptcy in 1847, and Edmund never owned his own home. Edmund either lived with his parents at Wincobank Hall or at the house at the Mills while working for the family company.

${ }^{550}$ Edmund Read to William Wilson, SSW, June 20, 1860, SSC, SSC 170, SCA; Wilson, Two Hundred Precious Metal Years, 94.

${ }^{551}$ See Sabean, Kinship in Neckarhausen, 10-11, 19, 23; Sabean and Teuscher, 2-3, $20,24$.
} 
family members ultimately decided to protect the family network over their own personal ambitions or interests. Therefore, this chapter proves that family networks and the nuclear family coexisted in the modern period by demonstrating further the strength of kinship ties in urban, industrial communities like nineteenth-century Sheffield.

The two family conflicts in 1847 and 1860 also provide an interesting example of the importance of signage in family correspondence. When the family network's links were strong, especially when members sought to persuade others to take a certain action or heed their advice, they used affectionate signatures which assured the recipient of their love for them and the strength of their familial ties. I argue that these reminders of family ties and affection would be doubly important amongst more distant relatives like uncles, nephews, and in-laws. Moreover, family conflicts demonstrate how a change in signature denoted alterations in the family dynamic and the threat of losing this close, loving, familial relationship. This phenomenon is evident in the 1847 quarrel through Uncle John's letter to Mary Anne, which unlike his past letters that were signed "your affectionate uncle," simply denoted himself as "Yours affectionately, John Read"; and in 1860, through Edmund's letters to Wilson that abandoned his traditional method of signing his letters- - Your affectionate brother." 552 This use of referencing one's relationship when signing letters was not unique to these parties, as Wilson's correspondence with his sister-in-law, Catherine Read, also used the emotive signatures, "Yours my dear Brother very affectionately" and "Your affectionate brother." ${ }^{553}$ These variations show how using or excluding references to one's familial connection to each other in correspondence

\footnotetext{
552 John Read to Mary Anne Rawson, [June 28, 1846], SSC, SSC 775, SCA; Edmund Read to William Wilson, SSW, June 13, 1860, SSC, SSC 170, SCA; Edmund Read to William Wilson, The Mills, February 16, 1837, SSC, SSC 738. My argument builds off a similar phenomenon in Barker's work on correspondence between fathers and sons. See Family and Business During the Industrial Revolution.

${ }^{553}$ William Wilson to Catherine Read, Radford, March 9, 1837, SSC, SSC 747, SCA; William Wilson to Catherine Read, Radford, March 25, 1837, SSC, SSC 747, SCA; Catherine Read to William Wilson, Wincobank, March 12, 1835, SSC, SSC 740, SCA.
} 
established a connection of affection and cooperation and how the elimination of these titles demonstrated displeasure and alienation.

\section{First Family Conflict, 1837-1847}

The Reads' correspondence evidences that even though the family could work together in times of struggle, individuals still sought their own gain or contested another person's actions if they were not conducive to the overall good of the family. In each of these cases, the individual utilized their role within the family network to address the benefits or repercussions that certain actions had on the entire family. Uncle John would face such a struggle in reconciling his personal desires with his obligations to his brother's family.

After his brother Joseph died in July 1837, Uncle John assumed the deceased's responsibility for the company and became responsible for his brother's family's maintenance. Uncle John fulfilled this role in several ways: he ensured that his widowed sister-in-law received an annuity of $£ 300$ from Read \& Co., gave Edmund a position at the company, and oversaw their daily expenses by "keeping [their] father's debts" and "providing" them with gifts like black silk dresses. ${ }^{554}$ These examples demonstrate the concept of reciprocity according to which Mary Anne and her family owed Uncle John their affection, appreciation, and respect in return for his attentiveness to their needs. In addition to these everyday acts of stewardship, Uncle John also considered making a more substantial compromise: purchasing Wincobank Hall "to prevent it going out of the family" [and thereby] sacrificing [his] own feelings to satisfy [his nieces' --

provided] he could dine there with any degree of pleasure." ${ }^{, 55}$ Regardless of this sentiment, when

\footnotetext{
554 Wilson, Two Hundred Precious Metal Years, 106; Mary Anne Rawson to John Read, [Suggested 1837-1840], MAR, MD 5692, SCA; Catherine Read to Anne Read, Torquay, [Suggested October 6, 1842], MAR, MD 5694, SCA.

555 John Read to Mary Anne Rawson, [Suggested 1837-1840], MAR, MD 6053, SCA.
} 
it was time to make this decision, it remains unclear if Uncle John could truly forfeit his own personal inclinations for the benefit of the family network.

It was not Uncle John who ultimately reinstated the family's ownership of Wincobank Hall-- Mary Anne repurchased it for her mother, daughter, and spinster sisters with a "legacy" from her deceased husband's cousin Frances Greaves' will in $1840 .{ }^{556}$ After purchasing the house, Mary Anne supplemented her family's income and supported their Sunday and Day schools by opening a girls' boarding school in her home, which unfortunately failed to thrive due to the school's inability to secure the "regular attendance" of enough clientele. ${ }^{557}$ Mary Anne's decision to seek respectable employment demonstrates that, rather than relying entirely on the family network, she protected her personal ambitions by seeking a means of independent income to support the members of the family living at Wincobank Hall and their charitable works.

Mary Anne was not the only one striving to further their own interests while advancing the wider family's goals. Edmund also pursued plans that he felt would simultaneously fulfill his personal ambitions while alleviating the family's financial troubles. The family's financial stability had never entirely resurged after Joseph's bankruptcy in 1837 and Read \& Co.'s future faced harsh uncertainty in 1844 due to their inability to effectively clear the company's debts. ${ }^{558}$ It was in this climate that Edmund wrote to Uncle John to persuade him to grant him more power and renumeration so that he could assume responsibility for repaying Read \& Co.'s debts. In order to do this, Edmund played upon his filial devotion to his uncle and his respect for his uncle's professional acumen while simultaneously proving his readiness to assume more

\footnotetext{
556 Wilson, Two Hundred Precious Metal Years, 105.

557 Taylor, "Life of Mary Anne Rawson," 10. Hall's study of Birmingham also included an example of Ann Morgan, a middle-class dissenter woman who opened up a boarding school in her home to support her family when her husband became too ill to work. See Hall, Civilising Subjects, 296.

${ }^{558}$ Elizabeth Read's Diary, December 22, 1844, MAR, MD 6042, SCA; Wilson, Two Hundred Precious Metal Years, 106-8.
} 
authority by referencing their current financial setbacks and offering potential solutions. ${ }^{559}$ These statements simultaneously proved Edmund's loyalty to his Uncle and willingness to submit to his authority and advocated for his capacity to take on more responsibility in the company. For reasons unclear within the family correspondence, Edmund was not granted his petition for more power and influence at Read \& Co. and two years later, in 1846, the family faced their second financial crisis.

Only nine years after their father, Joseph's, bankruptcy, the Reads' faced their second financial crisis, when Uncle John also became insolvent. This situation forced the family to utilize family duty to retain loyalty and obedience to the family network in a situation where anyone would be tempted to seek their own best interests. In these times of turmoil, the Reads relied on female members to solidify their ties to the extended family and remind them of their duty to protect the network's interests against their own. Mary Anne's letter revealed that affective ties played a powerful role in family networks: women's emotive and religious roles gave them responsibilities to advise their male family members on these matters - especially if it endangered the family network's cohesion.

Mary Anne's letter demonstrated that it was through her emotive, nurturing role in the family network that she was able to offer her uncle comfort and advice. Mary Anne extended respect and affection to her uncle in thanks for his past services to her family because she felt beholden to him; as she herself admitted, his "kindness [towards them had] brought him into [this dire] situation [and yet she] could do nothing to help or relieve [him]. ${ }^{560}$ After acknowledging her feelings of obligation and concern, Mary Anne set about using her affective influence to comfort and instruct.

\footnotetext{
${ }^{559}$ Edmund Read to John Read, The Mills, January 16, 1844, SSC, SSC 766, SCA.

${ }^{560}$ Mary Anne Rawson to John Read, Wincobank, January 19, [1846], SSC, SSC 716, SCA.
} 
Mary Anne reminded her uncle that all was not lost yet: "the real necessities and comforts of life are...few, and when all is settled,... we shall get on comfortably...[as] after all [this] dreadful anxiety a quiet life, even in a humble way [would] be a relief." ${ }^{561}$ This statement not only attempted to reassure her uncle - it also represented a deliberate hope that Mary Anne and her sister, Catherine, shared that their uncle's current trials would inspire him to stop seeking worldly pleasures and start focusing on the salvation of his immortal soul. ${ }^{562}$ Mary Anne and Catherine's framing of an economic crisis as an opportunity to foster a true Christian spirit and reliance in Christ demonstrates their true piety and complicates the assumption that faith merely served as a means to assert influence over social inferiors. This example suggests that though many scholarly works have focused on middle-class evangelical outreach to the lower classes, they have not considered how these women used similar methods of affectionate advice and gentle guidance to shepherd their own family members. What's more her fulfillment of the requirements of a doting niece freed her to address more controversial, public matters: how her uncle's current plans endangered the family network.

Mary Anne feared that her uncle's "fatigue and anxiety" had evolved into a state of apathetic disregard for the state of the business and a willingness to let other parties sort out what must be done without considering the situation carefully enough. She feared he had unquestioningly accepted his "greedy" solicitors Brookfield and Gould's advice that "a regular bankruptcy [was] the quickest easiest way of bringing things to a close, when perhaps it might be averted \& [he] may repent of it afterwards. ${ }^{" 563}$ Mary Anne had good reason to suppose that he would regret his idleness. Though Uncle John alleged that 'any termination would be almost the

\footnotetext{
${ }^{561}$ Mary Anne Rawson to John Read, Wincobank, January 19, [1846], SSC, SSC 716, SCA.

562 Mary Anne Rawson to John Read, Wincobank, January 19, [1846], SSC, SSC 716, SCA; Catherine Read to Mary Anne Rawson [Suggested Torquay, May 18, 1846], MAR, MD 5694, SCA.

${ }^{563}$ Mary Anne Rawson to John Read, Wincobank, January 19, [1846], SSC, SSC 716, SCA.
} 
same thing[,]' the options "seemed very different [to her: one] would not be known all through the country in the same way [as having] his name in the Gazette, and... every little thing belonging to [him] ... sold whether [he] like[d] it or not." ${ }^{\text {564 }}$ Mary Anne's arguments played to her uncle's sensibilities and opinions-- as he surely would not want to undergo the public embarrassment of declaring bankruptcy and auctioning off his carefully cultivated possessions-and forced him to consider how this action would impact the family's reputation.

After laying out her case, Mary Anne implored him to try to negotiate with the company's "principal creditors... [to see if] there was enough... to pay [so that they might] not proceed to extremities, but suggest some plan by which things might be more quietly wound up." ${ }^{565}$ This alternative would allow the family to settle their debts quietly and prevent public scandal, much as Uncle John's decision to assume his brother's debts and take over the company in 1837 had done. As this episode showed, Mary Anne's affective concern for her uncle enabled her to comment on matters of business and finance in order to steer Uncle John away from a path that would force him to endure the public shame of declaring bankruptcy and tarnish the family name by association. This episode demonstrates that even in matters such as one's bankruptcy a person could not act according to their own preferences alone-- they had to seek out what would be best for the family network.

When it became clear that Uncle John could not retain financial responsibility for the family company any longer, the Reads turned to Wilson once again for support. Wilson agreed to look into the business to determine if he could help his brother- and sisters-in-law without jeopardizing himself and found that the business's position was stable enough to take the risk. ${ }^{566}$

\footnotetext{
${ }^{564}$ Mary Anne Rawson to John Read, Wincobank, January 19, [1846], SSC, SSC 716, SCA.

${ }^{565}$ Ibid.

${ }^{566}$ William Wilson to Thomas Gould, London, June 5, 1846, SSC, SSC 773, SCA; Brookfield and Gould to William Wilson, Sheffield, June 30, 1846, SSC, SSC 773, SCA.
} 
Though the plan was financially safe, the emotional and social impact of this change led to the first family conflict in the summer of 1846 . This quarrel demonstrates two themes: changes in the professional hierarchy led to the breakdown of familial, emotive ties like respect and trust and female family members continued to play integral roles as negotiators within these disputes.

Tensions emerged over the process of transferring power from Uncle John to William Wilson. When the process of turning the company over to Wilson's control threatened to destroy the family network, Uncle John turned to Mary Anne to express his grievances and facilitate a return to amicable if not congenial relations. This phenomenon suggests another facet of reciprocity—men's ability to ask female family members for assistance or support. Just as women could use their moral and affective influence to ask for protection or aid for themselves and their families, men could call on women to act as intermediaries in grievances with members of the family network. This suggests that Uncle John played upon Mary Anne's gendered role as a go-between for the family network to seek recompense for the wrongs committed against him so that they could restore the family network's harmony.

Women's familial positions were important because even when a male family member recognized the dangers of family conflicts, they may have lacked the emotional influence or social diplomacy to address the rift. Uncle John certainly suggested that his pride kept him from repairing relations as he confessed that though he knew that "family quarrels [were] at all times foolish things... when a Man fe[lt] himself falling from the Station he has long filled, he [did] not like the last kick to come from... his own family." ${ }^{567}$ Mary Anne would recognize the paramount importance of reconciling her relatives as Uncle John was threatening to break all ties with Wilson and Edmund. As Uncle John hinted, this severance would have a serious impact on

\footnotetext{
${ }^{567}$ John Read to Mary Anne Rawson, [June 28, 1846], SSC, SSC 775, SCA.
} 
the family and would compromise their honor by making them fodder for gossip. ${ }^{568}$ This example underscores the serious consequences of these types of disagreements; they weakened family networks and opened the family up to community judgement and societal censure, especially if the rumors suggested (or worse proved) that Wilson and Edmund had behaved disreputably.

Uncle John accused Wilson and Edmund of behaving dishonorably in their designs to purchase the family business. Though Uncle John believed there were disrespectable or even sinister methods at play, upon reviewing the correspondence, it seems that the true problem lay in Wilson and Edmund's failure to show Uncle John the proper respect or regard for his feelings by excluding him from a series of decisions and ignoring his advice. In their haste to secure the family network's stability and protect Edmund's professional future, Wilson and Edmund had pursued their own benefit in business matters at the expense of Uncle John's frail dignity. Even after Uncle John told Wilson of his intentions to personally consult the creditors, Wilson preemptively acted on his own accord and purchased the "lease" to the house at the mills. Uncle John was so astounded by this maneuver that, when he first heard of it, he literally refused to believe that Wilson "would buy or the bank would sell [it] without [his] knowledge."

Wilson's side of the story paints a different picture: he had kept Uncle John updated on his progress throughout this process. Wilson proved this by remunerating that Uncle John had known that he was "in communication with the bank" as they had discussed the "bank's lease" and the Directors' acceptance of his “offer.” In Wilson's eyes, this communication refuted any suspicions of duplicitousness on his part. Uncle John's participation and cognizance of these developments suggests that the real cause of this tension was how swiftly the "premises" were

\footnotetext{
568 John Read to Mary Anne Rawson, [June 28, 1846], SSC, SSC 775, SCA.

569 Ibid.
} 
bought back, which Wilson reasoned was not due to any action of his own but rather that the bank directors were more cooperative than Read \& Co.'s creditors; he had "lost no time in pursuing both objects-- surely [it was not his fault] that one was accomplished before the other." Wilson denied willfully keeping information from Uncle John by confessing that he had not more openly discussed purchasing the lease to avoid inflicting unnecessary pain as "direct[ly] mention[ing]... it... to one who knew what [he] was attempting seemed needless... [and] indelicate. ${ }^{" 570}$ This explanation shows how affective ties and ideals about respect may have complicated the execution of business matters in family businesses—in sparing Uncle John's feelings Wilson had excluded Uncle John and opened himself up to charges of self-interest. Regardless of his supposed reason for these actions, Wilson's description of events acknowledged that Uncle John was (intentionally or not) kept in the dark about parts of this process.

The climax of Uncle John's suspicions came when the bank's representative, Mr. Watson, came to discuss the terms of him leaving the house at the mills. Before Wilson could even explain why he had purchased the lease without Uncle John's knowledge, Watson informed him that he must "give... up [the house] Wednesday first of July, within ten day[s]." flippant attitude and the social connotations of being kicked out of one's own home were too much to bear, especially for someone already sensitive to slight because of his bankruptcy and opprobrium. Uncle John railed against his mistreatment, calling their actions "contrary to all the usual courtesies of life." ${ }^{572}$ Despite the fact that Wilson was present when the bank representative shared this news, Uncle John felt that he had been duped and taken advantage of.

\footnotetext{
${ }^{570}$ William Wilson to John Read, July 14, 1846, SSC, SSC 776, SCA.

${ }^{571}$ John Read to Mary Anne Rawson, [June 28, 1846], SSC, SSC 775, SCA.

${ }^{572}$ Ibid.
} 
Wilson responded to the insinuation that he had treacherously schemed with the bank to humiliate Uncle John by clarifying that he had never "heard...of such a notice" and even if this report had been true there was nothing that he could gain from creating such an agreement. The terms that Uncle John described were not only 'contrary to all the courtesies of life' - but also "utterly futile \& illegal." In addition to this, Wilson reminded Uncle John that they had given him a copy of the notice and repeatedly assured him that he "could not be disturbed before Xmas.” Therefore, Wilson suggested that the "enigma" rose from Uncle John's confusing transfer of ownership of the rents with having "possession of the premises." 573 These examples suggest that Wilson had not done anything wrong and that Uncle John was actually most upset by how quickly and irreverently he was displaced as the leader of the company-before Wilson had even officially purchased Read \& Co.

Perhaps the largest (and most damning) source of Uncle John's anger, however, was how Edmund had treated him. Once it became clear that Wilson was going to assume control of the company, Edmund changed his deferential tone to one of insolence. Uncle John admitted that it was not so much the "matter" that Edmund brought forward that upset him but "the manner" in which he did it. ${ }^{574}$ Edmund's actions stemmed from his resentment of his uncle's treatment of him while he was in charge of the company. When Uncle John had tried to offer advice on matters of business, Edmund had tersely replied that "in six months it will be his own, \& he can then do as he likes" and had criticized his uncle for not paying his miniscule salary of $£ 100$ for the last three years. In order to defend himself, Uncle John reminded Edmund that he always intended to give him the business and its profits, that he faced serious financial setbacks from the company's debts, and that he had the considerable cost of Edmund's "living," "horse," and

\footnotetext{
${ }^{573}$ William Wilson to John Read, July 14, 1846, SSC, SSC 776, SCA.

574 John Read to Mary Anne Rawson, [June 28, 1846], SSC, SSC 775, SCA.
} 
"meals." ${ }^{\circ 75}$ As Hannah Barker's example showed, room and board were considered part of the wages of a young bachelor, apprentice son or in Edmund's case nephew and could be offered in lieu of a salary ${ }^{576}$ Regardless of this secondary source evidence that supports Uncle John's arguments, Wilson's comments on the subject defended Edmund's perspective. According to Wilson, Edmund “[n]ever benefited [from] the business during his father's life [when he] never had a salary-- or received above $£ 5 \ldots$ at a time [or under] his uncle [when] he had only $£ 100$ a year [on] a/c [of] their unfortunate debt.."577 Edmund's claim that he had a right to a higher salary and more influential position therefore served as a potential breaking point in the family network.

Though there are not any comments from Mary Anne on the matter, it is clear from Wilson's response that she communicated Uncle John's concerns to him. ${ }^{578}$ Her interference appears to have created an understanding between the parties which allowed Wilson and Edmund to continue on in their plans to purchase Read \& Co. Their success in restoring social cohesion, unfortunately, did not ease Wilson's path or help Uncle John's finances. From July to September 1846, Wilson continued to pursue negotiations with the creditors before purchasing the company in October 1846 and renaming it the Sheffield Smelting Company (hereafter SSC). ${ }^{579}$ Likewise, in October 1846 Uncle John was forced to sell his home, Derwent Hall, and

\footnotetext{
${ }^{575}$ John Read to Mary Anne Rawson, [June 28, 1846], SSC, SSC 775, SCA.

576 Barker, 111-114.

577 William Wilson to George Young, Nottingham, March 6, 1847, SSC, SSC 773, SCA.

${ }^{578}$ Wilson alludes to the fact that "various members of the family" have brought Uncle John's grievances to his attention. Since Wilson quoted material from Uncle John's letter to Mary Anne it seems most likely that she was one of the many who communicated with Wilson. Due to the similarities of subject matter as well as direct references to this letter, it is even possible that she forwarded Uncle John's letter to Wilson. See William Wilson to John Read, Wincobank, July 14, 1846, SSC, SSC 776, SCA.

${ }^{579}$ Wilson, Two Hundred Precious Metal Years, 111; Mr. Gould to William Wilson, July 15, 1846, SSC, SSC 773, SCA; William Wilson to S. Bailey, Wincobank, July 17, 1846, SSC, SSC 773, SCA; Henry Ed. Watson to Messrs. Brookfield \& Gould, Sheffield, August 25, 1846, SSC, SSC 773, SCA; Edmund Read to Henry Watson, Oak HillTorquay, August 24, 1846, SSC, SSC 773, SCA; Edmund Read to Henry Watson, Oak Hill- Torquay, August 29, 1846, SSC, SSC 773, SCA; Edmund Read to Henry Watson, Oak Hill, September 9, 1846, SSC, SSC 773, SCA; William Wilson to S. Bailey, Torquay, September 3, 1846, SSC, SSC 773, SCA; Edmund Read to Henry Watson,
} 
“almost all of his assets" to repay his brother's debts. ${ }^{580}$ The company's new name and management signified the end of an era and a period of great change for the Reads' family network.

\section{Second Family Conflict, 1846-1860}

Though Wilson faced the same challenges in obtaining cheap, abundant supplies of smelt that Joseph and Uncle John had, he was also more fortunate than his predecessors in several ways. His stewardship coincided with the end of the economic difficulties of the "hungry forties" and the "return [of] industrial prosperity." He also had the financial means to clear the company's past debts and the foresight to obtain more stable sources of capital through a new account with the Sheffield and Hallamshire Bank in December 1848. ${ }^{581}$ These challenges and solutions were reflected in an initial loss of $£ 1,256$ for the first two and a half years of business followed by a reversal of fortunes in June 1850 with a "profit" of $£ 1,326$ which was only broken briefly in 1854-6 during the Crimean War and promptly resurged again from 1857-9.582

Wilson also benefited from the experienced staff he acquired at the mills, including his brother-in-law Edmund who now had the work experience necessary to make him an asset to the company. ${ }^{583}$ Edmund's practical experience was crucial because, despite owning the SSC,

Oak Hill, September 9, 1846, SSC, SSC 773, SCA; William Wilson to S. Bailey, Torquay, September 3, 1846, SSC, SSC 773, SCA; William Wilson to Henry Watson, Torquay, September 12, 1846, SSC, SSC 773, SCA; Brookfield and Gould to Henry Watson, Royds Mills, September 12, 1846, SSC, SSC 773, SCA; Brookfield \& Gould to Henry Watson, Royds Mill, Sheffield, September 18, 1846, SSC, SSC 773, SCA; Articles of Agreement, SSC, SSC 774, SCA.

${ }^{580}$ Elizabeth Read's Diary, December 22, 1844, MAR, MD 6042, SCA; Wilson, Two Hundred Precious Metal Years, 106-8; "Derwent Hall, Derbyshire," Sheffield Independent, October 17, 1846, BNA; "Derwent Hall Estate," Sheffield Independent, July 25, 1846, BNA.

${ }^{581}$ Wilson, Two Hundred Precious Metal Years, 111, 116, 126. The hungry forties were a period economic depression in the early 1840s that blighted trade in Sheffield and led to harsh circumstances for trade, especially for the working classes. See Reid, "Middle-Class Values and Working-Class Culture in Nineteenth-Century Sheffield," $36,46,49,58$.

582 Wilson, Two Hundred Precious Metal Years, 112.

${ }^{583}$ Ibid. The Sheffield Smelting Company started with two employees its first week and grew to include nine on the second week and for a period after. 
Wilson did not have any formal training in smelting. Though he tried to educate himself on these matters by reading The Mining Journal, Wilson's research sometimes drove him to promote techniques that seemed innovative but were actually counter-intuitive, which Edmund had to respectfully reject. ${ }^{584}$ It was also obvious that Wilson trusted Edmund's judgement and ability as he sent him as a delegate to train the new manager of the London branch, William Bruce, in $1848 .{ }^{585}$ Wilson's reliance on Edmund's judgment and managerial skills provide important context for the second family conflict in 1860 .

The second quarrel in 1860 demonstrates another instance of the breakdown of trust and respect over misalignment between personal ambition and family strategy as well as the ongoing importance of women's roles as negotiators in family conflicts. Between April 1851 and May 1860 three crucial events occurred which displaced the previous structure of female negotiators within the family network. In April 1851, Wilson's wife, the Reads' sister Eliza died, some years afterwards Catherine Read left her long-standing residence in the Wilson household to care for her aging, blind mother at Wincobank Hall, and Mary Anne and Lizzie embarked on two voyages to Italy in 1857 and 1860. Though R. E. Wilson acknowledged these events in his history of the family business, he did not connect their occurrence with the breakdown of the family network. Eliza Wilson represented the link between Wilson and her natal family and therefore her death severed a crucial tie between Wilson and his in-laws. Moreover, with neither Catherine or Emily living in the Wilson household and Mary Anne and Lizzie travelling abroad,

\footnotetext{
${ }^{584}$ Wilson's research convinced him that they needed to install larger furnaces at the mills so that they could increase the amount of product yielded. Edmund's practical experience had proven that this was not a viable solution. Read \& Co's former manager, Lucas, had installed a "large furnace" that had only produced a slightly larger return and required twice as much money and time due to the need to process the material twice; even then, the results were sometimes unusable. See Wilson, Two Hundred Precious Metal Years, 113-4.

585 Ibid., 121, 130; Mary Anne Rawson to John Read, Wincobank, ND [Suggested 1854], MAR, MD 5697, SCA.
} 
the surviving female affinal links were also more distant than ever before. The consequences of these circumstances would be fully brought to light in the deterioration of Wilson and Edmund's relationship.

R. E. Wilson's account of the family also failed to acknowledge the serious threat that Wilson and Edmund's disagreement over Edmund's position in the company and corresponding salary caused within the family network. His account merely stated that Edmund had been denied a partnership and a raise and was then offered a joint partnership with his nephew John Wycliffe Wilson which he refused and instead retired. ${ }^{586}$ This depiction obscures the connection between masculinity, work, and reputation and women's roles as negotiators during family conflicts.

The 1860 quarrel started when Edmund sought to improve his personal situation by asking Wilson to fulfill an informal agreement to increase his salary. Much to Edmund's embarrassment, he had the awkward task of reminding Wilson that when he was "married [nine years ago, Wilson had] raised his Salary [and had] intimated that [he might] be able to increase it still further." 587 Though matters did not immediately descend into outright hostility, the correspondence clearly denotes strain and tension as Edmund's letters show that he waited a month for Wilson's response. ${ }^{588}$ Of particular importance was Edmund's reference to a letter from Wilson on June $7^{\text {th }}$ that agreed to reconsider Edmund's raise after "reviewing [their] correspondence from May 28, 1851." ${ }^{, 589}$ Wilson's silence on this topic, attested by Edmund's

\footnotetext{
586 Wilson, Two Hundred Precious Metal Years, 125, 127.

${ }^{587}$ Edmund Read to William Wilson, SSW, May 3, 1860, SSC, SSC 170, SCA.

${ }^{588}$ Edmund Read to William Wilson, SSW, June 8, 1860, SSC, SSC 170, SCA; Edmund Read to William Wilson, SSW, June 13, 1860, SSC, SSC 170, SCA; Edmund Read to William Wilson, SSW, June 20, 1860, SSC, SSC 170, SCA; Edmund Read to Henry Wilson, July 12, 1860, SSC, SSC 170, SCA.

${ }^{589}$ Unfortunately, many pieces of Wilson's correspondence in the Sheffield City Archives are either missing or so badly deteriorated that they are now illegible. For this reason, many of Wilson's responses, including that of June $7^{\text {th }}$ are lost. For Wilson's agreement to reconsider, see Edmund Read to William Wilson, SSW, June 13, 1860, SSC, SSC 170, SCA; Edmund Read to William Wilson, SSW, June 20, 1860, SSC, SSC 170, SCA.
} 
many letters asking the reason for his delayed response, suggests that Wilson had some reservations about fulfilling his supposed promise.

If Edmund did have written proof of this intention as he suggested, what could be keeping Wilson from honoring it? Perhaps Wilson had made a hasty, emotional offer that he now realized was financially and professionally unsound. 1851 was a hard year for William Wilson: in April his second wife, Edmund's sister, Eliza died, and in October-- the same month that Edmund was married-- his second eldest child (and first child by Eliza), Mary Eliza, died. With these two deaths within a few months of each other and Mary Eliza's death within the same month as Edmund's marriage, it is possible that Wilson's grief may have left him emotionally vulnerable enough to make an unwise promise to his deceased wife's brother. When Wilson refused to honor these supposed promises, the ties of loyalty and affection between Edmund and Wilson started to erode.

Edmund and Wilson fought over what loyalty Edmund owed the Wilsons and the SSC. Edmund argued that Wilson's failure to promote his professional aspirations by granting him a partnership or raising his salary evidenced that he had been mistreated. When negotiating his status at the company, Edmund refused to accept any "proposals [which acted] as if...[he was] a common ordinary clerk-- for such [he] ought never to be considered--" and demanded to be "placed in a pecuniary point, as if [he] were, and had been, a partner... for some time." 590 Edmund corroborated the fairness of this demand by pointing out that if he "had been...in many [other] businesses so long as...this [he] should have been made partner before this time. ${ }^{591}$ The company's history also attests to this as his father Joseph and Uncle John had been made partners when they turned 21, and two years after this quarrel, in 1862, Wilson would grant his sons

\footnotetext{
${ }^{590}$ Edmund Read to Henry Wilson, The Mills, July 16, 1860, SSC, SSC 170, SCA.

${ }^{591}$ Edmund Read to William Wilson, The Mills, July 19, 1860, SSC, SSC 170, SCA.
} 
Henry Joseph and John Wycliffe Wilson partnerships when they were 29 and 26 respectively. ${ }^{592}$ It seems that Edmund's late start in professional life may have displaced his professional trajectory - perhaps one was too old to start as a partner when they were 45 years old. Wilson and Edmund's conflicting notions of familial duty to one's affinal ties demonstrates Sabean's argument that marriage ties did not bind individuals together into unbreakable alliances as much as create relationships which would grant them favored positions of influence. Edmund did not see himself as unable to contest Wilson's idea and clearly found himself entitled to better treatment and consideration as Wilson's brother-in-law, particularly because he had worked to support Wilson and the company's interests for so long-- likely under an assumption he would someday be made partner.

Edmund's aggravations became a legitimization of his right to seek outside opportunities. The tensions between Edmund's obligations to the family network and his desire to fulfill his personal ambitions come to the forefront in Edmund's negotiations over terms of employment with a rival company interested in starting a business in Sheffield. Wilson was livid that Edmund had not immediately told him about the rival company and was convinced that Edmund was engaging in duplicitous behavior to ruin the SSC. Perhaps Wilson imagined that Edmund was capable of such double-dealing because Edmund actually had provided Wilson with important details or information that helped him take over the company in the months leading up to their quarrel with Uncle John in the summer of 1847. Nonetheless, Wilson's connection to the family and utility to the family network surely served as extenuating circumstances that would excuse such sharing, since Edmund ostensibly always viewed Wilson's purchase as a unified strategy undertaken by the family network.

${ }^{592}$ Wilson, Two Hundred Precious Metal Years, 56, 63, 132. 
Edmund's actions in this instance demonstrate that he traversed the delicate balance between personal ambition and family loyalty. Though Wilson claimed he had behaved dishonorably by failing to prioritize protecting the Wilsons' and the SSC's interests, Edmund insinuated that Wilson unfairly expected him to accept the responsibilities of a partner without its rewards; Edmund did not think that "such a step [was] absolutely necessary for one who has been treated as a mere underling-- subject to be turned away at any moment-- \& not a partner." 593 Regardless of this spiteful reply, Edmund could not entirely shake feelings of obligation to the Wilsons and the SSC.

Despite the fact the he did not have a stable or prestigious position at the company, Edmund alleged that he had not behaved dishonorably towards the Wilsons in his dealings with the rival business. Contrary to Wilson's accusations, Edmund had originally only entered into communications with them to gain information on potential "opposition" -- it was purely coincidental that he and Wilson argued about his salary at this time. Regardless of his current disagreement with Wilson, he had deliberately avoided harming the family's interests: he had never revealed any of the company's current troubles to any person and the rival company's "opposition" was not any worse than if he had not taken a step in the matter." 594

Edmund took pride in his conduct in this matter and clearly thought he had the moral high ground. He affirmed that "if they "kn[e]w a good deal of S. S. Co.'s plans, they know nothing whatever from [him: he had] never spoken a word or given a hint to a single man... for [he] should not have felt justified in doing so [even if] some... thought [he was] foolish... [for] carrying....scruples...to [such] a length. ${ }^{, 595}$ Edmund therefore not only fulfilled his obligations to

\footnotetext{
${ }^{593}$ Edmund Read to William Wilson, The Mills, July 20, 1860, SSC, SSC 170, SCA.

${ }^{594}$ Edmund Read to Henry Wilson, The Mills, July 12, 1860, SSC, SSC 170, SCA.

${ }^{595}$ Edmund Read to William Wilson, The Mills, July 20, 1860, SSC, SSC 170, SCA.
} 
his brother-in-law who he felt had abused and antagonized him, but had treated him with more respect and loyalty than some thought he deserved.

Edmund obviously sought to avoid public scandal by keeping their quarrel private, and it seems unlikely that he would disclose his undervalued position and antagonistic relationship with his current company's owner in his conversations with the rival company. Informing them of his unhappy and desperate prospects would only hinder his chances of negotiating advantageous terms with them. Furthermore, the prospect of Edmund not only leaving, but working for another local business granted him leverage so he would not want to burn any bridges with the SSC. Either way, Edmund would not need to disclose information now-- he could still use his knowledge about the SSC's mills to hurt the Wilsons once he was hired by their rivals. Regardless of Edmund's intentions, his conversations with the rival company fulfilled an indispensable purpose: they legitimated his demands for a higher salary by providing him with evidence that his experience made him a valuable asset even without any promises or "family connexion[s]." ${ }^{596}$ The potential threat posed by Edmund leaving the company convinced Wilson to offer Edmund a joint partnership with his son, John Wycliffe Wilson.

Though this appeared to grant Edmund's demands, Edmund refused to accept his offer. Edmund did not explain exactly why he rejected the joint-partnership — he only stated that while he initially intended to accept the offer, after "looking into the matter and seeing how the arrangement would work" he had realized that he must decline it. ${ }^{597}$ The notion of sharing power with his young nephew after he had waited so long to be named partner must have made the offer unpalatable. It certainly did not grant him proper credit and acceptance in the company's hierarchy if it merely placed him as equal to his nephew. Just as Edmund had allowed his father,

\footnotetext{
${ }^{596}$ Edmund Read to Henry Wilson, The Mills, July 12, 1860, SSC, SSC 170, SCA.

${ }^{597}$ Edmund Read to William Wilson, The Mills, July 27, 1860, SSC, SSC 170, SCA.
} 
Uncle John, and Wilson to assume control first, he likely thought that he deserved the right to be full partner as thanks for his years of diligent service and his personal connection to the family business. Or, perhaps he feared that his young nephew would undermine his influence and restrict his hard-earned authority since they both held the title of partner. Therefore, he stated that he would not accept the position of joint-partner but would continue working for the SSC with a $£ 500$ salary and $£ 250$ annuity. ${ }^{598}$

Edmund's decision to turn down the offer of joint-partnership perplexed Wilson. $\mathrm{He}$ thought Edmund behaved "unwisely... [by] declin[ing] [the] offer of partnership" as such an position would guarantee him a "positive a certainty (as far as business matters of that kind can be considered). ${ }^{" 599}$ Wilson's incredulousness at Edmund's refusal of joint-partnership likely stemmed from the fact that Wilson saw it as the obvious and best possible solution. Much like Edmund had assumed that as a bachelor, Uncle John must intend to give him control of the company, Wilson probably deemed it pointless to place the company solely in Edmund's hands when his own fortune had saved the company and he, unlike Edmund, had sons to carry on the business. For this reason, Wilson assumed a joint-partnership represented the limits of his obligations to his brother-in-law and the natural, pragmatic choice as the company would inevitably become a Wilson enterprise after Edmund's retirement.

Though the arguments were over matters of business, the tensions soon spread into family matters and threatened to weaken the ties between the Wilsons and the Reads. Wilson and Edmund's quarrel led to a breakdown of trust that created isolation and strain and nearly severed the family network's ties. Edmund and Wilson's correspondence devolved from amiable letters

\footnotetext{
${ }^{598}$ Edmund Read to William Wilson, The Mills, July 27, 1860, SSC, SSC 170, SCA.

599 William Wilson to Edmund Read, Mills 11.45, July 28, [1860], SSC, SSC 170, SCA.
} 
discussing the running of the family business and assuring each other of their respect and affection to tools each could use against the other to protect their self-interests. ${ }^{600}$

From the very beginning of the quarrel in 1860, Edmund had emphasized the importance of communicating about his future prospects in writing, which suggested that he had doubts about Wilson fulfilling his promise after many years of silence on the subject. ${ }^{601}$ Three months later, Edmund's stance had only intensified as he demanded that the conditions had to be in writing: since they "attach[ed] such widely different meanings to words and expressions [he could] not be satisfied to receive any guarantee without ... an impartial person['s]... opinion of its meaning and bearing. " 602 This comment demonstrated that Edmund felt it necessary to have evidence that would compel Wilson to keep his word as well as allow him to ask other parties if its wording offered Wilson any loopholes. Both points must have seemed especially necessary after Wilson had refused to carry out his supposed earlier promise to increase his salary.

This distrust was not one-sided. Wilson demanded that Edmund promise (in writing) that if he returned to the company he would dedicate himself to the business. Wilson's suspicion about Edmund's work ethic and trustworthiness seriously offended Edmund and led Edmund to propose that "if [Wilson had] no more opinion of [his] principles than [the] last letter implie[d]... [it was] perhaps as well ...that our connexion [may] be near its close."603 These comments

\footnotetext{
${ }^{600}$ Comparing Edmund and Wilson's correspondence from 1835 and 1837 to these letters in 1860 proves this point. See Edmund Read to William Wilson, The Mills, April 8, 1835, SSC, SSC 738, SCA; Edmund Read to William Wilson, The Mills, December 17, 1836, SSC, SSC 738, SCA; Edmund Read to William Wilson, The Mills, December 17, 1836, SSC, SSC 738, SCA; Edmund Read to William Wilson, The Mills, April 8, 1835, SSC, SSC 738, SCA; Edmund Read to William Wilson, The Mills, October 22, 1835, SSC, SSC 738, SCA; Edmund Read to William Wilson, The Mills, December 14, 1835, SSC, SSC 738, SCA; Edmund Read to William Wilson, November 17, 1836, SSC, SSC 738; Edmund Read to William Wilson, The Mills, February 4, 1837, SSC, SSC 740.

${ }^{601}$ Edmund Read to William Wilson, SSW, May 3, 1860, SSC, SSC 170, SCA.

${ }^{602}$ Edmund Read to Henry Wilson, The Mills, July 16, 1860, SSC, SSC 170, SCA.

${ }^{603}$ Edmund Read to William Wilson, The Mills, July 20, 1860, SSC, SSC 170, SCA.
} 
demonstrate how this quarrel had seriously damaged Wilson and Edmund's confidence in each other and weakened the family network.

There is further evidence of how the family conflict in 1860 strained family ties and led to alienation amongst the branches through the example of Edmund denying his nephew the right to call on him. Edmund warned Henry Joseph not to visit him to try to negotiate the terms of his salary and annuity as Edmund did not intend to deviate from any of his demands so the trip would be a waste of his nephew's "valuable...time" and "a letter [would] better answer every purpose. ${ }^{\circ 04}$ This clause that correspondence was a better vehicle for this conversation suggests that he wanted to avoid being manipulated by a personal, emotional appeal and to have a guarantee through written proof of their agreement. Family loyalty also shifted according to how the relationship impacted their other familial duties. Edmund and Wilson's letters reveal that a core part of Edmund's concerns related to how his professional instability hindered his ability to fulfill his domestic duties as a husband.

Edmund often supported his right and need for a more secure position and a higher salary by emphasizing how his current situation impacted his wife. For instance, he asserted that Wilson's refusal to answer whether he would raise his salary interfered with his provisionary roles as a husband. Wilson's failure to respond to his questions left him unable to respond to a predicament in his household staff: one of his servants had handed in her notice because she refused to work in "such a smoky, dirty place [any longer]." ${ }^{" 605}$ Though this may seem trivial, Tosh and others have shown that since men's familial roles were provisionary ones, Edmund's masculine responsibilities as a husband included keeping his wife in the respectable conditions

\footnotetext{
${ }^{604}$ Edmund Read to Henry Wilson, The Mills, July 16, 1860, SSC, SSC 170, SCA.

${ }^{605}$ Edmund Read to William Wilson, SSW, June 20, 1860, SSC, SSC 170, SCA. A letter from Emily Read corroborated the mills was an unpleasant, smoky, dirty dwelling. Emily Read to Anne Read, The Mills, August 8, 1835, MAR, MD 5696, SCA.
} 
appropriate to their station. ${ }^{606}$ If, as Edmund alleged, the servant had refused to accept the responsibility of working in these conditions, household aid must have been especially necessary for maintaining respectable levels of comfort and cleanliness.

Edmund's position was doubly difficult because the house that he and his wife lived in at the mills actually belonged to the company-- if he left the SSC he would have to give it up. ${ }^{607} \mathrm{In}$ addition to being part of the family business empire, the house-- though "smoky and dirty"-- held sentimental value as the place where Mary Anne and her sisters, if not Edmund himself, were born. Moreover, as a middle-class man Edmund's masculinity hinged on his ability to provide for his family. If his house was not his own but technically owned by his brother-in-law and dependent upon his work at SSC, it is not surprising that Edmund would be concerned about Wilson's refusal to offer him any guarantees for his future status at the company.

There is further evidence that Edmund's dependence on Wilson's authority within his own home strained his masculine identity in Edmund's demands for returning to the company. He explicitly stated that he must "be allowed to consider my house entirely my own and not be obliged to keep a room for [Wilson] and if... the smoke and dirt or other nuisances [should] make...it needful [to be allowed] to remove to another house." ${ }^{608}$ Later letters also demonstrate that this policy was not in order to restrict Wilson's presence but to give Edmund a pretense of authority within his own home.

Edmund expressed his gratitude that Wilson had agreed to "give up [his] room in our house- - it was] a great convenience to [his wife and himself-- but they would nonetheless] be glad to accommodate [him]... on receiving a little notice of [his] intentions.. ${ }^{\prime 609}$ This comment

\footnotetext{
${ }^{606}$ Bailey 171-5; Tosh, A Man's Place, 4, 107-8; Harvey, 532-3, 535-6.

${ }^{607}$ Edmund Read to William Wilson, The Mills, July 13, 1860, SSC, SSC 170, SCA.

${ }^{608}$ Edmund Read to Henry Wilson, The Mills, July 16, 1860, SSC, SSC 170, SCA.

${ }^{609}$ Edmund Read to William Wilson, The Mills, July 19, 1860, SSC, SSC 170, SCA.
} 
suggests that Wilson used to come to Sheffield without notice expecting to stay in a room in their home which was specially set aside for his convenience. Regardless of family ties and affectionate feelings, such an obligation must have been a source of anxiety for Edmund's wife and an embarrassing, emasculating reminder of Edmund's dependence on Wilson. Wilson's status as the owner of the company and the house suggests that even after this, the agreement was merely a courtesy as the SSC still owned the house.

Edmund also framed his demands for a larger salary as necessary to allow him to provide for his wife. His current low rate of compensation did not allow him to "make adequate provision for the future:" he needed a higher salary that would "enable [him] to save considerably for [his] wife, [which was] of course of the first importance in [his] view. ${ }^{610}$ In this way, the ability to provide for one's wife, even after one's death, serves as further evidence of the demands of provisionary masculinity. Edmund's adamance about his salary and annuity therefore related to his masculine role within the family network by securing an adequate source of income to provide for his wife.

Edmund also protected his wife's future interests by trying to obtain yearly payment for her after he died. Edmund gradually reduced his demands from $£ 100$ annually, to waiving her annuity if they increased his salary now with a caveat that they would pay her $£ 50$ a year if he died within ten years, to relying on Wilson's honor and hoping that he would give her $£ 50$ a year if he should die in the next five years. ${ }^{611}$ As Edmund's mother had received an annuity from the company, this may have been another instance where Edmund believed Wilson denied him the professional respect that he deserved due to his service and connection to the business.

\footnotetext{
${ }^{610}$ Edmund Read to William Wilson, The Mills, July 19, 1860, SSC, SSC 170, SCA.

${ }^{611}$ Edmund Read to Henry Wilson, The Mills, July 16, 1860, SSC, SSC 170, SCA; Edmund Read to William Wilson, The Mills, July 19, 1860, SSC, SSC 170, SCA.
} 
Wilson and Edmund's quarrel also demonstrates women's roles as negotiators by revealing the devastating consequences of their displacement within the family network and men's inability to adequately fulfill this role. When Wilson's son, Edmund's nephew, Henry Joseph, tried to mediate, he was unsuccessful. His efforts only prompted Edmund to rehearse his father's wrongs against him, reminding Henry Joseph that he had only pursued "what [he] considered [his] father's promise to give [him] a better Salary"; it was his father who had "declined to entertain the question and refus[ed]...even the right to petition for more... after taking a month to consider... it [and] urg[ed] [him] to leave if...not satisfied \& content." A further illustration of Henry Joseph's failure to intercede between his father and uncle was Edmund's rebuff to his nephew's plea that 'the breach [between the families] may yet be repaired.' Rather than inspiring a spirit of contrition or reconciliation, Edmund only aloofly commented that he did not have any "quarrel [with Henry Joseph's] father, nor [any] wish for one;" he had "simply asked for an increase of Salary and was refused, with an intimation that [he] had better go if...not content - \& therefore [he was] follow[ing] the advice \& giv[ing] notice to go-- where is the quarrel?",612

The family conflict of 1860 could only end after the female family members resumed their roles as negotiators in the family network. Edmund's sisters, especially Catherine, utilized their emotive, caring positions in the family network to restore harmony by reminding Edmund and Wilson of their ties to each other and responsibilities to protect the family network's interests. As Edmund himself admitted, it was only his sisters' "regret [over the] bad feeling which opposition might naturally produce [and fears that it would] widen the breach between families [and] give a very unfavourable impression to [the public that] persuaded [him] ... to

${ }^{612}$ Edmund Read to Henry Wilson, The Mills, July 12, 1860, SSC, SSC 170, SCA. 
[seek] an amiable settlement." ${ }^{\prime 613}$ Edmund's reference to his sisters' wishes requires consideration.

Though it is unclear if Edmund's older sisters truly cowed him into submission, the most thought-provoking aspect of this claim remains the level of influence his sisters had within this decision. Months of ineffective negotiating and threatening only desisted once they became involved in the matter. This phenomenon offers further evidence to scholarly works on kinship and family history that affirm women played a central role as links within the family network. Conversely, if his sisters did not have this level of influence, what would Edmund gain by framing this concession as his sisters' desires? Perhaps utilizing his sisters' feelings enabled him to reconcile with Wilson without his brother-in-law becoming defensive. If this plea came from Wilson's sisters-in-law rather than his business associate, Wilson would be obligated to listen out of standards of propriety, masculine obligation to female dependents, and societally accepted norms of women's authority on emotional and familial matters. Either way, the notion that the female members of the family wanted to restore harmony created the impetus for ending this fight.

Even more interestingly, the sisters' intervention not only brought their brother to heel, but also compelled Wilson to negotiate with Edmund. Wilson openly admitted that only the "family feelings [expressed to him in] a letter from our dear sister Catherine... whom [he sympathized with]... believing she [fe[lt] perhaps more than any of us all the hardship... [prevented him from giving] a decided negation to [Edmund's] proposals. ${ }^{\circ 614}$ It is worth noting that Wilson used the term "our sister Catherine" which reinstated their pseudo-sibling relationship. Moreover, it was Edmund's sisters who came up with the option that ultimately

\footnotetext{
${ }^{613}$ Edmund Read to William Wilson, The Mills, July 28, 1860, SSC, SSC 170, SCA.

${ }^{614}$ William Wilson to Edmund Read, Mills 11.45, July 28, [1860], SSC, SSC 170, SCA.
} 
diffused the situation: Edmund would retire now with an $£ 275$ annuity or would remain as long as necessary until his nephew John Wycliffe had "sufficient experience in the business... to manage it satisfactorily." 615

Regardless of the sisters' wishes, the breach could not be healed that easily-even after Wilson and Edmund resolved to reconcile, their letters reveal their suspicions about each other's loyalty and self-serving interests. For instance, a miscommunication over the agreed upon terms created fresh antagonism between the two men. After Edmund wrote to accept what he thought was Wilson’s offer of $£ 400$ as salary and $£ 250$ on retirement, Wilson peevishly informed him that if he "look[ed] at [his] letter again [he would] see the annuity was $£ 250$ if [he] decided to leave [now---] not whenever [he] decided to leave." ${ }^{616}$ Edmund recalcitrantly apologized for his mistake - he "hoped [Wilson] did not think [he]...want[ed] in any way to take advantage of [him]" - and accepted the offer to "retire" now 'bonafide [sp] and friendly., ${ }^{617}$ Edmund's "hope" that Wilson did not suppose he had written the first time to try to trick him into agreeing to a different deal or negotiating further demonstrates that Wilson's suspicions of foul play affronted him.

For his part, Wilson clearly believed that Edmund had manipulated him throughout the last three or four months. He told Edmund that he could comfort himself with knowing he had "the honour of having fought a hard battle \& the satisfaction of "dying game" \& carrying a good share the spoils!" Regardless of his suspicions, Wilson claimed that he did not want to give up on repairing the relationship between the two families: he was "still...desirous to cultivate kindly feeling [and] sincere [in his wish to] try [to reconcile themselves]." ${ }^{\prime 18}$ Wilson's angry words

\footnotetext{
${ }^{615}$ Edmund Read to William Wilson, The Mills, July 28, 1860, SSC, SSC 170, SCA.

${ }^{616}$ William Wilson to Edmund Read, The Mills 2.0, July 28, 1860, SSC, SSC 170, SCA.

${ }^{617}$ Edmund Read to William Wilson, The Mills, [suggested after Wilson's 2.0] July 28, 1860, SSC, SSC 170, SCA.

${ }^{618}$ William Wilson to Edmund Read, The Mills 2.0, July 28, 1860, SSC, SSC 170, SCA.
} 
suggest that he perhaps felt it was his duty to make up with his brother-in-law to avoid scandal and to appease his sisters-in-law as he did not seem to want to reconnect with Edmund.

Even after agreeing to retire, however, the two disagreed on what loyalty Edmund owed the Wilsons and his former company. Edmund considered retirement as an opportunity to gain a secure income from the SSC while enabling him to pursue work at another company more willing to promoting his professional aspirations. Therefore, Edmund demanded that upon retirement he would have the free[dom] to do whatever [he] liked without any sort of conditions." ${ }^{619}$ Wilson refused to accept this clause and wanted to protect the interests of his nuclear family and the SSC. This argument revealed the tensions between Edmund's familial duty and his personal, professional ambitions.

Edmund wholeheartedly "agree[d] not to enter into any business... in opposition to" the Wilsons but worried that "the way" Wilson had "worded" this clause would force him to choose between keeping his annuity or serving as a "manager" or "partner... in a like business." In Edmund's eyes, this was unreasonable: his "annuity would be for past services [so Wilson] could never object to [him] endeavoring to increase it in any way, provided it did not interfere with [Wilson's] interest or those of [his] family." ${ }^{620}$ Edmund did not win this battle. Instead, he had to accept that he would lose his annuity if he decided to work for another company. In other words, Edmund ultimately chose family ties over personal ambition or individualism.

Though he could have protected his personal, professional interests by seeking employment elsewhere and engaging in competition with his brother-in-law and nephews, Edmund chose to protect the family's interests - to submit himself to the will of the family network. This concession stemmed not from the fact that his loyalty superseded his own

\footnotetext{
${ }^{619}$ Edmund Read to Henry Wilson, The Mills, July 16, 1860, SSC, SSC 170, SCA.

${ }^{620}$ Edmund Read to William Wilson, The Mills, July 19, 1860, SSC, SSC 170, SCA.
} 
ambitions or remained static and untestable, but because his sisters reminded him of the importance of family connections and the need to protect the wider group's interests. The Reads' family conflicts in this chapter therefore demonstrate that despite the rise of individualism, especially in the competitive world of modern industry, nuclear and extended family ties coexisted — even if they were tested by claims of self-interest and personal ambition.

\section{Conclusion}

The Reads' family conflicts in 1846 and 1860 reveal that understandings of family loyalty fluctuated based on their circumstances and the family network's willingness to meet individual's needs and desires. As in the case of Cain and Abel, families had to consider if they were truly responsible for their kin and question the limitations of loyalty to extended kin. Decisions about family loyalty ultimately boiled down to the advantages or disadvantages of the alliance and the family's ability to retain ties of obligation to the members of their family network.

For example, during the quarrel between Uncle John and Wilson and Edmund in 1846, notions of family loyalty shifted due to the increasing influence of Wilson within the family network as the future head of the company and Uncle John's corresponding receding role. Uncle John believed that Wilson and Edmund had taken advantage of his weakness and were seeking to elevate themselves at his own expense by throwing him out of the house at the mills and hiding their plans and intentions from him. In actuality, Wilson and Edmund were not scheming about how to swindle and humiliate Uncle John - they seemed to have completely overlooked him in their rush to make plans and secure the company's future.

Uncle John's suspicions stemmed from his outrage at their treatment, which contradicted what he saw himself as being entitled to as the former head of the company and key actor in the 
family network who had sacrificed his own interests to support them and had gone bankrupt as a consequence. What's more, Mary Anne's letter from January 1846 proved that he had earned such solicitude for his services to their family. Edmund and Wilson focused their attention not on the past which had led to this second financial crisis, but on how they could move forward from it and protect the family's interests. Family loyalties were therefore shifting from Uncle John who had served the family network to Wilson who represented their hope for the future.

The family's behavior in this action represented another example of how the definition of family loyalty changed according to individual context. Edmund and his natal family prioritized protecting Edmund's financial and professional future, which were both directly linked to the family company. Since Wilson represented their best potential hope of resolving the company's financial problems, they chose him. This did not mean, however, that they excommunicated Uncle John from the family network-his success in writing to Mary Anne to address his grievances proved that they still had ties of obligation to him. Rather, the main problem issued from Wilson's usurping Uncle John's role in the family network, and his nieces' and nephew's acceptance of this new pecking order before Wilson had even purchased the company.

Similarly, the family conflict between Edmund and Wilson in 1860 proves that ideas about loyalty change according to individual circumstances. As Sabean argued in Property, Production, and Family in Neckerhaussen, marriage did not represent a definite system of ties which established obligations; rather, it placed the two parties in relationships that granted them consideration and influence. Before 1860, Edmund remained loyal to Wilson because he assumed that his services to him and the company would be rewarded with a partnership. When he realized that Wilson did not intend to further his interests, Edmund saw it as within his rights to look for work that would appreciate his expertise. Though he reserved his right to protect his 
personal ambitions, Edmund did not completely cut ties with his family connections. His goal was to find a situation that would allow him to advance his interests, but according to his letters, he would not agree to do so at the detriment to the family company. Moreover, family ties and loyalty to the Wilsons won in the end. It was ultimately his sisters' reminder of the necessity of family ties and the importance of supporting his nephew's professional interests that succeeded. Edmund chose to retire and continue to support the family business rather than seek his own benefits - a sign that neither the nuclear family nor the extended family completely lost influence in the nineteenth-century world of business.

Women played a crucial part in the sustaining of these ties - a fact that helps explain why the resilience of family ties was ignored in traditional scholarship on the modern period. ${ }^{621}$ In both of these family conflicts, women served as intermediaries communicating the concerns and addressing the grievances of both parties. Interestingly in the example from 1846, Uncle John called upon Mary Anne to act as a go-between and air his complaints about Wilson and Edmund's behavior. Uncle John's decision to reach out to Mary Anne demonstrated women's accepted roles as mediators in family conflict and suggested a reciprocal aspect within reciprocity: men and women utilized each other for help according to their gendered roles as provisioners and professionals or filial, domestic, affective advocates. This phenomenon is further shown in the devastating results of women's lack of mediating presence due to Eliza Wilson's death in April 1851, Catherine's permanent residence in Sheffield rather than with the Wilsons, and Mary Anne and Lizzie's journeys to Italy. The serious nature of the escalation of tensions between Wilson and Edmund, the failure of Henry Joseph Wilson to reconcile his father

\footnotetext{
${ }^{621}$ David Warren Sabean and Sylvia Yanagisako made a similar point in arguing that kinship networks' influence on politics was not recognized in traditional scholarship due to the uncontested acceptance of the ideology of the separation spheres and associations of family matters with women's work. See David Warren Sabean, Kinship in Neckarhausen, 11; Yanagisako, 42-3.
} 
and uncle, and the fact that the quarrel only ended after Edmund's sisters interceded proves that women used their affectionate, filial roles as sisters to settle interfamily disputes. In other words, advising and cajoling male family members remained central to women's emotive, nurturing domestic, familial roles in the family network.

In addition to revealing women's roles as negotiators, the two conflicts in 1846 and 1860 demonstrate the connections between men's masculine roles as providers and their professional roles. They show how Uncle John and Edmund's public, professional images were weakened by the family's bankruptcies and Wilson's purchase of the company. Uncle John's bankruptcy and Edmund's failed attempt to become a partner reveal that their masculine domestic roles as providers and property holders depended upon their status within the company. In both cases, Uncle John and Edmund's financial troubles hindered their position in the family. Uncle John's bankruptcy led to the sale of the family company and the loss of his professional identity as its owner. Edmund's inability to secure a partnership placed him in a vulnerable, dependent position without any certainty about his place within the company and complicated his ability to support his wife.

Furthermore, the fact that both Uncle John and Edmund lost the right to live at the house at the Mills illustrates how crucial their professional identities were to their ability to mimic the characteristics of masculine property ownership. The family's reduced circumstances since 1837 made the house at the mills a crucial resource for supporting family members. Uncle John and Edmund's precarious financial and professional positions offer unique insight into how deeply interconnected professional and domestic ideas of men's place in the home and the family were. In their examples, losing their positions also meant being evicted from their homes. Conversely, Wilson's status as a paragon of masculinity due to his financial stability, professional 
accomplishments as the owner of two successful businesses and various homes, and social standing as a husband and father serves as a foil to compare and contrast Edmund and Uncle John's public failures. In each of these situations, male and female family members dealt with the strains and measured the consequences of acting as "their brother's keeper[s]." 


\section{Conclusion}

I was thinking how it would do for... Dr. Alliott to preach at Wincobank [Thursday] evening, and then for him to remain with you until Saturday when he would go to Masbro.... He said how very much he should like it if he did fix to stay. I think Wincobank is quite noted as a resting place for Ministers, for Mrs. Alliott said directly how much she wished he could go-- She thought-- it would do him some good. ${ }^{622}$

My dear Parents were very hospitable, and it was always a pleasure to them to entertain, not merely their old friends, but any distinguished strangers who came into the neighborhood, and who quickly became friends. And it was a great enjoyment and advantage to us, even occasionally, to have the opportunity of seeing and hearing the conversation of superior persons, especially as there was around us a great lack of improving society. We always invited Montgomery when we had any guests we thought he would like to see, or would like to see him: and at different times he met here, Dr. Marshman, John Sheppard, Jane and Isaac Taylor, Mr. and Mrs. Gilbert, Mr. \& Mrs. Ellis, Sir Francis Chantray, Dr. Winter Hamilton, Dr. Raffles, Josiah Conder, Dr. Pye-Smith, and Dr. McCall. ${ }^{623}$

In many ways, the Reads' home, Wincobank Hall, served as a central character within this case study. It symbolized their wealth and influence, their financial problems and the uncertainties of business, their philanthropic outreach, and their social and familial networks. In other words, the home performed a central task as not only the family's dwelling, but a structure directly related to their identities as Nonconformists, manufacturers, and philanthropists.

At the beginning of this case study, Wincobank Hall evidenced the Reads' social status and affluence. Joseph's decision to leave the industrial area of Attercliffe to settle in the gorgeous countryside affirms the industrial narrative in which manufacturers moved away from the dirty, crowded condition of cities into grand houses in the suburbs. The house itself proved the family's wealth as its rooms and setting denoted respectability through its dining room, drawing room, butler's pantry, library, housekeeper's room, seven bedrooms, nine dressing rooms, servants' quarters, carriage house, stables, and gardens. Even the family's financial

\footnotetext{
622 Catherine Read to Mary Anne Rawson, Plumptre House, [June 10, 1841], MAR, MD 5694.

${ }^{623}$ Mary Anne Rawson, “The Memorials of James Montgomery,” JMC, SUA.
} 
difficulties and eventual loss of the home performed an integral role in facilitating an understanding of what insights the Reads' experiences offer broader scholarship.

Wincobank Hall remained a central figure in the Reads' story — even after the family left it in 1834. Throughout this project, various homes have played a pivotal part in the family narrative: in 1834 Joseph decided to move back to the house at the mills, in 1840 Mary Anne repurchased Wincobank Hall, and in 1846 Uncle John lost the house at the mills and Derwent Hall. In each of these circumstances, removal, return, and relocation unveiled how these properties shaped the Reads' identity as a respectable, manufacturing family.

Furthermore, the Reads' tumultuous relationships regarding home ownership contradicts a prevailing assumption in historical scholarship. Though many studies assume that wealth and security were constants in the nineteenth century, the Reads' experiences demonstrate that fortunes fluctuated based on economic conditions, familial decisions, and financial pressures from outside institutions like banks. Even more importantly, the Reads' model represents the true standard of life for middle-class businessmen. By focusing on families who accumulated great wealth like the Cadburys or Wedgwoods rather than families whose businesses failed (sometimes even repeatedly) scholars have skewed representations of urban industrial business.

As Twell's study also showed, Wincobank Hall also played an integral role as the center of the family's charitable outreach before and after their financial problems. Wincobank Hall facilitated Mary Anne and her sisters' charitable development by acting as the epicenter of their family's engagement in poor relief. Additionally, the house functioned as a venue for their religious and moral outreach. In both 1817 and 1841, their home and property served as the location for the family's local chapel and Sunday School to promote piety, faith, and religious education amongst their neighbors. And, when Mary Anne established the Wincobank Total 
Abstinence Society in 1841 the hall became a meeting site for the family teetotal society's meetings and events.

Wincobank Hall was also a social, familial space where like-minded reformers and affectionate friends and family came together. As the opening vignettes suggested, many of the family's letters and reflections describe the influential and prominent individuals that the family met and forged bonds of friendship with. These included famous literary figures like James Montgomery and Anne Taylor Gilbert, who were also fellow anti-slavery supporters, the missionary George Bennet, the Italian nationalist, Giuseppe Mazzini, and American abolitionist, Frederick Douglas. In addition to these famous guests, the Reads invited Congregationalist ministers and teetotal lecturers to their home as part of their religious and moral outreach, which in turn allowed them to establish social, religious, and philanthropic networks. Finally, it served as a space that fostered the bonds between the Wilson children and their Read aunts, uncle, and cousin during the Wilsons' extended stays in Sheffield. This overview of Wincobank Hall's role in the family's lives also resonates with this project's larger themes: the importance of men and women's gendered, kin roles in family networks and businesses; the role of business, middleclass morality, and respectable sociability in nineteenth-century middle-class identity; the permeability of the public and private within middle-class women's charitable work; and the dangers of assuming that these figures' faith were merely tools to assert and protect middle-class social authority.

As chapters two and six showed, the Reads' family network proved that men and women played specific gendered, kin roles within the family network and the family business. For men, these responsibilities included overseeing the business and protecting the family's financial interests. Men's familial roles were directly connected to their status as wage earners and 
supporters of their female dependents. In other words, men's professional lives directly affected their personal lives and vice versa. Even women, who scholars once assumed did not have any influence in the world of business, contributed to the family enterprise as a part of their domestic roles within the family. The Reads' case study evidenced that middle-class women participated in discussions about the family business and even took part in family strategies and business negotiations that sought to protect and promote the family's financial and professional interests. In each of these cases, the Read women utilized their gendered, kin roles as caring, concerned daughters, sisters, and nieces to advocate on others' behalves, offer advice, and mediate disputes.

Chapters two, three, four, and five of this study demonstrated the role of income, professionalism, middle-class values, and respectable sociability in their personal identities. For the men of the family, their self-worth, public position, and influence within the family network depended upon their ability to financially support their families and manage the business. The family's letters clearly reveal the importance of the family business within men's personas and future interests as displayed by the family strategies offered and conflicts over position and payment. As chapter five showed, individual circumstances and personal ambitions directly impacted notions of family loyalty—leading to shifting allegiances and notions of obligation to different members of the family network.

Similarly, female family members' philanthropic work articulated the importance of respectability and sociability in women's engagement in the community. The Read sisters' engagement in charitable enterprises like anti-slavery societies, the Society for Bettering the Condition of the Poor, Bible Societies, Lancastrian Schools, Sunday Schools, and teetotal societies reveal how conceptions of respectability, middle-class morality, and acceptable social practices informed and empowered their participation in the public sphere. This case study 
provides further evidence of the fallacy of a separation of spheres by proving the truly permeable nature of the public and private in middle-class women's family networks and charitable work.

Catherine Read, Emily Read, Mary Anne Rawson, and Lizzie Rawson's engagement in the family's Sunday School and teetotal society underscored that middle-class women utilized contemporary ideals about domesticity and femininity to perform their gender-sanctioned roles within the community. In both cases, maternalism (or the idea that elite women had a duty to watch over their social inferiors because of their elevated status, position as moral authorities, and inherently caring, sympathetic natures) empowered their ability to effect change in their neighborhood. Chapter three reveals how spinster women like Catherine and Emily Read performed their gendered roles as mothers by guiding and instructing their nieces and nephews and Sunday School students. This chapter used their examples to prove that though contemporaries worried about the fate of "surplus women," single women gained fulfillment, purpose, and respect through their maternalistic, philanthropic roles as doting aunts and affectionate teachers.

Similarly, chapter four studies the fluidity of conceptions of public and private by analyzing the Rawsons' work in their family's teetotal society. This case study argues that the family utilized ideas about women's domestic roles and the sanctity of the home to establish their own teetotal society that promoted sobriety amongst the Wincobank villagers. The Wincobank Total Abstinence society manipulated ideas about the public and the private by utilizing the Reads' home as a venue and thereby playing upon notions of sociability to excuse women's leadership in a traditionally male movement. Chapters three and four therefore show that the Read/ Rawson women assumed maternalistic duties in their roles as caretakers and educators in the family's Sunday School and teetotal society. 
Though other works have also addressed these themes, the nature of the Reads' family network and their charitable work offers unique contributions to scholarship. The Reads' family network represents a compelling study because the majority of its members defy the traditional norm emphasized in other studies of family networks: husbands and wives. Though Elizabeth and two of her daughters, Mary Anne and Eliza, married, none of these couple groups survived for the entirety of this case study: Mary Anne and Elizabeth became widows in 1829 and 1837 respectively and when Eliza died in 1851 William Wilson became a widower. Moreover, the family featured a large percentage of individuals who do not conform to the traditional narrative on men and women's gender roles. Catherine and Emily never married, making it impossible for them to fulfill their supposedly "natural" positions as wives and biological mothers. ${ }^{624}$ Likewise, Uncle John's bachelors status and Edmund's failure to produce any children in his marriage placed them on the periphery as most scholarship on eighteenth- and nineteenth-century masculinity emphasized the importance of middle-class fatherhood.

Lastly, the Reads prove the integral role of religious convictions in the female family members' personal identities and its influence upon their charitable work. Family correspondence evidences that all of the women in this case study held devout, dedicated personal faith systems reflective of the impulse of the Evangelical Revival and contemporary Congregationalism; their personal faith and charitable works emphasized the same topics synonymous with these religious movements: personal salvation, religious outreach, moral and scriptural education, and repentance of one's sins. Moreover, their letters offer ample proof of their identification with inner piety, also known by evangelicals as "inward religion" or "heart

\footnotetext{
${ }^{624}$ Though their aunt, Uncle John's sister, Anne Read is not covered in this project's case studies, she too was a spinster. Her example therefore lends even more credibility to my argument.
} 
religion." ${ }^{625}$ Examining articulations of faith by individuals within this family unit provides an opportunity to reconcile religious fervor with class authority.

Though the Reads' charitable work did inherently bolster their class position and local authority by reinforcing their own social and cultural biases, this project's case studies offer little evidence that the family deliberately used these ventures to garner social power or communal authority. Rather, their work in the Sunday School and WTAS suggests that though they may have tried to influence and reform their lower-class neighbors, they could not force wayward Sunday School girls or Joseph Sellars to accept their values-let alone change their ways. Furthermore, there is a striking similarity between their attempts to cajole wayward family members like Uncle John to take their faith more seriously and their interactions with lower-class individuals. In both cases, the Read women used affection, concern, and persuasion to remonstrate with complacent Christians and potential victims of drunkenness. The family's moral and religious outreach, as well as their mentoring of their family members, therefore, suggested that the Reads felt compelled to help others as a part of their evangelical Christian duty to improve others' spiritual and moral lives. ${ }^{626}$ Despite the fact that the Read name died out with Edmund's death in 1873, the Reads' influence as industrial, middle-class philanthropists had an enduring legacy in Sheffield.

The Wilson children and their offspring carried on the Reads' legacy as dissenter manufactures and philanthropists even after the last member of this case study, Mary Anne, passed away in 1887. William Wilson's sons Henry Joseph (“H. J.”) Wilson and John Wycliffe (“J. W.") Wilson took over control of the Sheffield Smelting Company in 1862. The family's connection to the smelting works endured for at least two hundred years with the male

\footnotetext{
${ }^{625}$ Brunner, 79; Rivers, 155.

${ }^{626}$ Bebbington, Evangelicalism in Modern Britain, 11.
} 
descendants of Reads/ Wilsons holding partnerships in the company for one hundred and thirty years and serving as working directors from 1890 on. ${ }^{627}$ Henry Joseph's life suggests that he upheld his grandparents', parents', and aunts' model: he served as a Liberal MP for Holmfirth from 1885-1912 and was a vehement teetotaler and pacifist. He and his wife, Charlotte Wilson, also fought to protect women and prostitutes from victimization in their opposition to the Contagious Diseases Acts. ${ }^{628}$

Henry Joseph and Charlotte's eldest son, Cecil Wilson, followed in his father's footsteps as a dedicated pacifist and Labour MP in $1922 .{ }^{629}$ And, their daughter, Dr. Helen Wilson, earned notoriety as one of the first (if not the first) female doctors and the first female magistrate in Sheffield. She also carried on her ancestor's legacies of charity and reform. Helen fought to aid prostitutes as the Secretary of the British Association for Moral and Social Hygiene in 1910, supported the Neighbour Guilds Association that helped poor communities in Sheffield, and advocated for passive demonstrations for women's emancipation. ${ }^{630}$

William Wilson's second son in this business partnership—John Wycliffe Wilson—also continued the family model of charitable relief by serving as the Chair of the Board of Guardians for the Fir Vale Workhouse and proponent of the Salvation Army. His daughter, Dr. Ruth Mary Wilson-yet another female doctor amongst the Reads' progeny_ also supported the Salvation Army in Sheffield by serving as Salvation Army Warden of the home. Even more compellingly, the Wilsons reestablished Wincobank Hall's tradition of providing aid to needy families by founding the first Salvation Army rescue home in Sheffield from 1899-1915.

\footnotetext{
${ }^{627}$ Wilson, Two Hundred Precious Metal Years, xi.

${ }^{628}$ Twells, The Civilising Mission and the English Middle Class, 112. H. J. Wilson's wife faced criticism for her involvement in such a controversial issue. See Price, 65.

${ }^{629}$ Price, 118.

${ }^{630}$ Ibid., 96.
} 
Unfortunately, Wincobank Hall was torn down in the 1920s due to its severely dilapidated state. ${ }^{631}$ The boys' school that the family constructed in 1841 , however, still stands and serves as a community center, now known as the Wincobank Undenominational Chapel. In 2017, local historians and community members gathered to celebrate the two-hundred-year anniversary of the Reads' opening of their chapel in Wincobank Hall's carriage house. As these examples show, the Reads' legacy though underrepresented in historical scholarship had a crucial and enduring impact on life in Sheffield in the late nineteenth and early twentieth centuries that in some cases still carries on to this day.

The Reads represent a group of influential manufacturing dissenters who shaped local and national history in nineteenth-century England. The family's unique circumstances reveal several scholarly assumptions or misinterpretations: an emphasis on successful business ventures during the volatile world of nineteenth-century business, the problematic nature of the family paradigm of wives/ mothers and husbands/ fathers, and a dismissive attitude toward piety and faith's relationship to philanthropy. The Read family's correspondence attests to their establishment of dynamic kinship and philanthropic networks that furthered their engagement in pivotal charitable ventures within the town. Studying the family's charitable activism and their attempts to protect and promote the family business, Read \& Co., offers insights into many scholarly discussions, including middle-class cultural identity, gender roles, piety, philanthropy, and social outreach, family business and financial crisis during the era of industrial and capital development, and the role of the family and kinship in modern Europe.

631 “With Dr. Ruth Wilson," The Deliverer, October 1904; Archeritage, "Wincobank Hill," Archeological Report (Sheffield: Archeritage, 2011), http://www.wincobanklivinghistory.co.uk/home/wincobank-hall.aspx. 
Autumn Mayle

Respectable Women, Ambitious Men: Gender and Family Networks in Victorian Sheffield Bibliography

\section{Primary Sources}

I. Manuscript Collections

Mary Anne Rawson Collection, Sheffield City Archives

Sheffield Smelting Company Collection, Sheffield City Archives

H. J. Wilson Papers, Sheffield City Archives

Letters of Wilson Family, Sheffield City Archives

James Montgomery Collection, Sheffield University Archives

Wilson Children Correspondence, Nottingham Archives

William Wilson Correspondence, Nottingham Archives

Henry Ward Beecher's Sermons, Evangelical Library

Correspondence of W. B. Rawson, Dr. Williams' Library

Joseph Read and Rotherham College Correspondence, Dr. Williams’ Library

\section{Press}

Sheffield Independent, Sheffield, 1820-1850

Sheffield Iris, Sheffield, 1817-1825

Westmoreland Gazette, Kendal, 1856

The Deliverer, London, 1904

Evangelical Magazine, London, 1830-1850

The London Times, London, 1817-1825

\section{Published and Digital Primary Sources}

Fordyce, James. Sermons to Young Women. American ed. Philadelphia: M. Carey, 1809.

Gisbourne, Thomas. An Enquiry Into the Duties of the Female Sex. 8th ed. London: W. Heseltine, 1810.

Holland, John. The Picture of Sheffield: Or, An Historical and Descriptive View of the Town of Sheffield in the County of York. Sheffield: Ridge, 1824.

Leader, R. E. Reminiscences of Old Sheffield: Its Street and Its People. Sheffield: Leader and Sons, 1875.

Odom, William. Hallamshire Worthies: Characteristics and Work of Notable Sheffield Men and Women. Sheffield: J. W. Northend, 1926.

Sheffield Female Anti-Slavery Society. Annual Reports of the Sheffield Female Anti-Slavery Society, 1826, 1827,1832. Accessed March 20, 2020. www.jstor.org/stable/60238182. 
Sheffield Ladies' Anti-Slavery Society. Annual Reports of the Sheffield Ladies Anti-Slavery Society, 1828-30. Accessed March 20, 2020. www.jstor.org/stable/60239510.

Stickney Ellis, Sarah. Mothers of England: Their Influence and Responsibility. London: Fisher, Son, and Co., 1843.

Taylor, John. The Illustrated Guide to Sheffield And the Surrounding District Comprising Accounts of the Early History and Progress of the Town, Its Public and Religious Bodies, Edifices, and Institutions, Descriptions of Its Manufactures, and of the Suburban Scenery and Places of Interest in the Surrounding District, \&c. Sheffield: Pawson and Brailsford, 1879.

White, William. General Directory of the Town and Borough of Sheffield: With Rotherham, Chesterfield, and All the Parishes, Townships, Villages, and Hamlets Within a Circuit of Twelve Miles Round the Capital of Hallamshire. Sheffield: R. E. Leader, 1845.

“With Dr. Ruth Wilson.” The Deliverer, October 1904.

\section{Secondary Sources}

Aaslestad, Katherine. "Patriotism in Practice: War and Gender Roles in Republican Hamburg, 17501815. In Gender, War, and Politics: Transatlantic Perspectives, 1775-1830, edited by Gisela Mettele and Jane Rendall. New York: Palgrave Macmillan, 2010.

Adams, Christine. "Constructing Mothers and Families: The Society for Maternal Charity of Bordeaux, 1805-1860.” French Historical Studies 22, no. 1 (1999): 66-86.

Alexander, Ruth M. 'We Are Engaged as a Band of Sisters': Class and Domesticity in the Washington Temperance Movement, 1840-1850.” Journal of American History 75, no. 3 (1988): 763-785.

Archeritage. "Wincobank Hill.” Archeological Report. Sheffield: Archeritage, 2011. http://www.wincobanklivinghistory.co.uk/home/wincobank-hall.aspx.

Arnstein, Walter L. Queen Victoria. Basingstoke, Hampshire: Palgrave Macmillan, 2003.

Bailey, Joanne. "Masculinity and Fatherhood in England, 1760-1830." In What Is Masculinity?

Historical Dynamics from Antiquity to the Contemporary World, edited by John Arnold and Sean Brady. Basingstoke, Hampshire: Palgrave Macmillan, 2011.

Barker, Hannah. Family and Business During the Industrial Revolution. Oxford: Oxford University Press, 2017.

Bebbington, David. Evangelicalism in Modern Britain: A History from the 1730s to the 1980s. London: Routledge, 1989. 
Bebbington, David. Victorian Nonconformity. Bangor, Gwynedd: HEADSTART HISTORY, 1992.

Berend, Zsuzsa. 'The Best or None: Spinsterhood in Nineteenth-Century New England.” Journal of Social History 33, no.4 (2000): 935-957.

Broomfield, Andrea. Food and Cooking in Victorian England: A History. Westport, CT: Praeger, 2007.

Brown, Callum G. The Death of Christian Britain: Understanding Secularisation 1800-2000. London: Routledge, 2001.

Brunner, Daniel L. "The 'Evangelical' Heart of Pietist Anthony William Boehm.” In Heart Religion: Evangelical Piety in England and Ireland, 1690-1850, edited by John Coffey. Oxford: Oxford University Press, 2016.

Campbell Orr, Clarissa. Queenship in Europe, 1660-1850: The Role of the Consort. Cambridge: Cambridge University Press, 2004.

Carey, Brycchan. British Abolitionism and the Rhetoric of Sensibility: Writing, Sentiment, and Slavery, 1760-1807. Basingstoke, Hampshire: Palgrave Macmillan, 2005.

Ceri Jones, David. “George Whitefield and Heart Religion.” In Heart Religion: Evangelical Piety in England and Ireland, 1690-1850, edited by John Coffey. Oxford: Oxford University Press, 2016.

Clapp, E. J. and J .R. Jeffrey. Women, Dissent, and Anti-Slavery in Britain and America, 17901865. Oxford: Oxford University Press, 2011.

Clark, Anna. The Struggle for the Breeches: Gender and the Making of the British Working Class. Berkeley: University of California Press, 1995.

Cookson, Gillian. "Family Firms and Business Networks: Textile Engineering in Yorkshire, 17801830s.” Business History 39, no. 1 (1997): 1-20.

Colley, Linda. Britons: Forging the Nation, 1707-1837. New Haven: Yale University Press, 2009.

Corbett, Grace, Richard O’ Neill, and Andrea Burgess. “Archeological Excavations at Wincobank Hall, Sheffield.” Transactions of the Hunter Society 27 (2018): 29-44.

Corfield, Penelope J. Power and the Professions in Britain, 1700-1850. London: Routledge, 1995.

Cowman, Krista. "Women, Locality and Politics in Nineteenth-Century Britain." In Gender in Urban Europe: Sites of Political Activity and Citizenship, 1750-1900, edited by Krista Cowman, Nina Javette Koefoed, and Karlsson Sjogren. London: Routledge, 2014.

Cox, Nancy. The Complete Tradesman: A Study of Retailing, 1550-1820. Aldershot, Hants: Ashgate, 2000. 
Davidoff, Leonore and Catherine Hall. Family Fortunes: Men and Women of the English Middle Class, 1780-1850. London: Routledge, 1987.

Davidoff, Leonore, Megan Doolittle, Janet Fink, and Katherine Holden. The Family Story: Blood, Contract, and Intimacy 1830-1960. New York: Longman, 1999.

Davidson, Denise Z. "The New (Emotional) Regime: Bourgeois Reactions to the Turmoil of 18141815." French History Studies 42, no. 4 (2019): 595-621.

Dieleman, Karen. Religious Imaginaries: The Liturgical and Poetic Practices of Elizabeth Barrett Browning, Christina Rossetti, and Adelaide Procter. Athens: Ohio University Press, 2012.

Digby, Anne. Making a Medical Living: Doctors and Patients in the English Market for Medicine, 1720-1911. Cambridge: Cambridge University Press, 1994.

Duncan, Alison. "Power and the Old Maid: The Never-Married Gentlewoman in Her Family, 17401835." Women's History Magazine, 63 (2010): 11-18.

Earle, Peter. The Making of the English Middle Class: Business, Society and Family Life in London 1660-1730. London: Methuen London, 1989.

Fowkes Tobin, Beth. "The Tender Mother": The Construction of Motherhood and the "Lady's Magazine." Women's Studies 18, no. 2 (1990): 205-21.

Francus, Marilyn. Monstrous Motherhood: Eighteenth-Century Culture and the Ideology of Domesticity. Baltimore: John Hopkins University Press, 2012.

Fromer, Jule E. A Necessary Luxury: Tea in Victorian England. Athens: Ohio University Press, 2008.

Fuchs, Rachel F. Gender and Poverty in Nineteenth-Century Europe. Cambridge: Cambridge University Press, 2005.

Geddes Poole, Andrea. Philanthropy and the Construction of Victorian Women's Citizenship: Lady Frederick Cavendish and Miss Emma Cons. Toronto: University of Toronto Press, 2014.

Gleadle, Kathryn. Borderline Citizens: Women, Gender, and Political Culture in Britain, 1815-1867. Oxford: Oxford University Press, 2009.

Gerard, Jessica. "Lady Bountiful: Women of the Landed Classes and Rural Philanthropy." Victorian Studies 30, no. 2 (1987): 183-210.

Gomersall, Meg. "Ideals and Realities: The Education of Working-Class Girls, 1800-1870.” History of Education 17, no. 1 (1988): 37-53. 
Gomersall, Meg. "Women's Work and Education in Lancashire: A Response to Keith Flett." History of Education 18, no. 2 (1989):153-62.

Grassby, Richard. Kinship and Capitalism: Marriage, Family, and Business in the English-Speaking World, 1580-1740. Cambridge: Cambridge University Press, 2001.

Gunn, Simon and Rachel Bell. The Middle Class: Their Rise and Sprawl. London: Phoenix, 2002.

Gunn, Simon. The Public Culture of the Victorian Middle Class: Ritual Authority and the English Industrial City 1840-1914. Manchester: Manchester University Press, 2000.

Hagemann, Karen. "Female Patriots: Women, War, and the Nation in the Period of the PrussianGerman Anti-Napoleonic Wars." Gender and History 16, no. 2 (2004): 397-424.

Hall, Catherine. Civilising Subjects: Metropole and Colony in the English Imagination, 1830-1867. Chicago: University of Chicago Press, 2002.

Hall, Catherine. "The Sweet Delights of Home." In A History of Private Life: From the Fires of Revolution to the Great War, edited by Michele Perrot. Harvard University Press, 1990.

Hall, Catherine. White, Male, and Middle Class: Explorations in Feminism and History. New York: Routledge, 1992.

Harrison, Brian. Drink and the Victorians: The Temperance Question in England 1815-1872. Pittsburgh: University of Pittsburgh Press, 1971.

Harvey, Karen. "Men Making Home: Domesticity in Eighteenth-Century Britain." Gender and History 21, no. 3 (2009): 520-40.

Hill, Bridget. Women Alone: Spinsters in England, 1660-1850. New Haven: Yale University Press, 2001.

Holland, Lynda. "A Family Affair: A Nineteenth Century Tale of One Family and Its Business." Family and Community History 14, no. 1 (2011): 24-40.

Hopkins, Mark. Nonconformity's Romantic Generation: Evangelical and Liberal Theologies in Victorian England. Carlisle, Cumbria: Paternoster Press, 2004.

Horowitz, Sarah. Friendship and Politics in Post-Revolutionary France. University Park, PA: Penn State University Press, 2014.

Hudson, Pat. "Financing Firms." In The Rise of the Modern Firm, edited by Geoffrey Jones and Walter A. Friedman. Cheltenham: Edward Elgar Publishing Limited, 2012.

Hunt, Margaret R. The Middling Sort: Commerce, Gender, and the Family in England, 1680-1780. Berkeley: University of California Press, 1996. 
Johnson, Christopher H. Becoming Bourgeois: Love, Kinship, and Power in Provincial France, 16701880. Ithaca: Cornell University Press, 2015.

Joris, Elisabeth. "Kinship and Gender: Property, Enterprise, and Politics." In Kinship in Europe: Approaches to Long-Term Development, 1300-1900, edited by David Warren Sabean, Simon Teuscher, and Jon Mathieu. Oxford: Bergham Books, 2007.

Kashuba, Wolfgang. “German Burgerlichkeit after 1800: Culture as Symbolic Practice.” In Bourgeois Society in Nineteen Century Europe, edited by Jurgen Kocka and Allen Mitchell. London: Bloomsbury Academic, 1993.

Kingsley Kent, Susan. Queen Victoria: Gender and Empire. Oxford: Oxford University Press, 2016.

Kish Sklar, Kathryn and James Brewer Stewart. Women's Rights and Transatlantic Antislavery in the Era of Emancipation. New Haven: Yale University Press, 2007.

Klingaman, Nicholas and William Klingaman. The Year Without Summer: 1816 and the Volcano that Darkened the World and Changed History. New York: St. Martin's Press, 2013.

Kramnick, Isaac. "Religion and Radicalism: The Political Theory of Dissent." In Republicanism and Bourgeois Radicalism. Ithaca: Cornell University Press, 1990.

Larsen, Ruth. "For Want of a Good Fortune: Elite Single Women's Experiences in Yorkshire, 17301860." Women's History Review 16, no. 3 (2007): 387-401.

Lester, V. Markham. Victorian Insolvency: Bankruptcy, Imprisonment for Debt, and Company Winding-up in Nineteenth-Century England. Oxford: Clarendon Press, 1995.

Levine, Phillipa. "So Few Prizes and Many Blanks: Marriage and Feminism in Later NineteenthCentury England.” Journal of British Studies 28, no. 2 (1989): 150-74.

Lewis Shiman, Lillian. Crusade Against Drink in Victorian England. New York: St. Martins Press, 1988.

Lindenauer, Leslie J. Piety and Power: Gender and Religious Culture in the American Colonies, 1630-1700. New York: Routledge, 2002.

Martin, Moira. "Single Women and Philanthropy: A Case Study of Women's Associational Life in Bristol, 1880-1914.” Women's History Review 17, no. 3 (2008): 395-417.

McCormack, Matthew. "Introduction." In Public Men: Masculinity and Politics in Modern Britain, edited by Matthew McCormack. Basingstoke, Hampshire: Palgrave Macmillan, 2007. 
McCormack, Matthew. "Men, 'the Public' and Political History." In Public Men: Masculinity and Politics in Modern Britain, edited by Matthew McCormack. Basingstoke, Hampshire: Palgrave Macmillan, 2007.

Medick, Hans and David Warren Sabean, eds. Interest and Emotion: Essays on the Study of Family and Kinship. Cambridge: Cambridge University Press, 1984.

Midgley, Clare. Feminism and Empire: Women Activists in Imperial Britain, 1790-1865. London: Routledge, 2007.

Midgley, Clare. Women Against Slavery: The British Campaigns, 1780-1870. London: Routledge, 1992.

Modesti, Adelina. "Margherita de' Medici Farnese: A Medici Princess at the Farnese Court." In Medici Women : The Making of a Dynasty in Grand Ducal Tuscany, edited by Giovana Benadusi and Judith C. Brown. Toronto: Center for Renaissance and Reformation Studies, 2015.

Mollona, Massiliano. "An Ethnography of Industrial Work and Politics.” In Made in Sheffield. New York: Berghahn Books, 2009.

Mood, Jonathan. "Women in the Quaker Community: The Richardson Family of Newcastle, c. 18151816." Quaker Studies 9, no. 2 (2005): 204-19.

More, Charles. The Industrial Age: Economy and Society in Britain, 1750-1995. London: Longman, 1997.

Morgan, Simon. A Victorian Woman's Place: Public Culture in the Nineteenth Century. London: Tauris Academic Studies, 2007.

Morris, Robert John. Class, Sect, and Party: The Making of the British Middle Class: Leeds, 18201850. Manchester: Manchester University Press, 1990.

Morris, R. J. Men, Women, and Property in England, 1780-1870: A Social and Economic History of Family Strategies amongst the Leeds Middle Classes. Cambridge: Cambridge University Press, 2005.

Navickas, Katrina. “'That Sash Will Hang You:' Political Clothing and Adornment in England, 17801840." Journal of British Studies 49, no. 3 (2010): 540-65.

Nelson, Claudia. "Wives and Husbands." In Family Ties in Victorian England. Westport, Conn: Praeger Publishers, 2007.

Newbon, Pete. The Boy-Man, Masculinity and Immaturity in the Long Nineteenth Century. London: Palgrave Macmillan, 2019. 
O'Leary Paul. Claiming the Streets: Processions and Urban Culture in South Wales, c. 1830-1880. Cardiff: University of Wales, 2012.

Owens, Alastair. "Inheritance and the Life Cycle in Family Firms in the Early Industrial Revolution." Business History 44, no. 1 (2002): 21-46.

Perrot, Michelle. "Stepping Out." In A History of Women in the West, Emerging Feminism from Revolution to World War, edited by Genevieve Fraise and Michelle Perrot. Cambridge: Harvard University Press, 1993.

Perry, Ruth. "The Importance of Aunts." In Novel Relations: The Transformation of Kinship in English Literature and Culture, 1748-1818. Cambridge: Cambridge University Press, 2004.

Pollard, Sydney. A History of Labour in Sheffield. Liverpool: Liverpool University Press, 1959.

Porter, Roy. Creation of the Modern World: The Untold Story of the British Enlightenment. London: W. W. Norton and Company, 2000.

Post, John D. The Last Great Subsistence Crisis in the Western World. Baltimore: Johns Hopkins University Press, 1977.

Price, David. Sheffield Troublemakers: Rebels and Radicals in Sheffield History. Andover, Hampshire: Phillimore \& Co., 2008.

Raggio, Osvaldo. Feuds and State Formation, 1550-1700: The Backcountry of the Republic of Genoa. Translated by Matthew Vester. Cham, Switzerland: Palgrave Macmillan, 2018.

Rappaport, Erika. "Sacred and Useful Pleasures: The Temperance Tea Party and the Creation of a Sober Consumer Culture in Early Industrial Britain." Journal of British Studies 52, no. 4 (2013): 990-1016.

Reddy, William. The Navigation of Feeling: A Framework for the History of Emotions. Cambridge: Cambridge University Press, 2001.

Reid, Caroline. "Middle-Class Values and Working-Class Culture in Nineteenth-Century Sheffield." $\mathrm{Ph}$. D diss, University of Sheffield, 1976.

Reid, Caroline. "Temperance, Teetotalism, and Local Culture: The Early Temperance Movement in Sheffield." Northern History 13 (1977): 248-64.

Richardson, Sarah. The Political Worlds of Women: Gender and Politics in Nineteenth-Century Britain. Hoboken: Taylor and Francis, 2013.

Rivers, Isabel. "Inward Religion and Its Dangers in the Evangelical Revival." In Heart Religion: Evangelical Piety in England and Ireland, 1690-1850, edited by John Coffey. Oxford: Oxford University Press, 2016. 
Sabean, David Warren and Simon Teuscher. "Kinship in Europe: A New Approach to Long-Term Development." In Kinship in Europe: Approaches to Long-Term Development (1300-1900), edited by David Warren Sabean, Simon Teuscher, and Jon Mathieu. New York: Berghahn Books, 2007.

Sabean, David Warren. Kinship in Neckarhausen, 1700-1870. Cambridge: Cambridge University Press, 1998.

Sabean, David Warren. Property, Production, and Family in Neckarhausen, 1700-1870. Cambridge: Cambridge University Press, 1990.

Salenius, Sirpa. An Abolitionist Abroad: Sarah Parker Remond in Cosmopolitan Europe. Amherst: University of Massachusetts Press, 2016.

Sanchez, Magdalena S. 'Lord of My Soul': The Letters of Catalina Micaela, Duchess of Savoy, to Her Husband, Carlo Emanuele.” In Early Modern Habsburg Women: Transnational Contexts, Cultural Conflicts, Dynastic Continuities, edited by Anne J. Cruz and Maria Galli Stampino. Farnham: Ashgate, 2013.

Scott, Joan W. "Gender: A Useful Category of Historical Analysis.” The American Historical Review 91, no. 5 (1986): 1053-75.

Seal, Graham. "Tradition and Agrarian Protest in Nineteenth-Century England and Wales." Folklore 99, no. 2 (1988): 146-69.

Smith, Dennis. Conflict and Compromise: Class Formation in English Society, 1830-1914; A Comprehensive Study of Birmingham and Sheffield. Boston: Routledge and Kegan Paul, 1982.

Snell, K. D. M. "The Sunday School Movement in England and Wales: Child Labour, Denominational Control and Working-Class Culture." Past and Present 164, no. 1 (1999):122168.

Standish, Meacham. “The Evangelical Inheritance.” Journal of British Studies 3, no. 1 (1963): 88104.

Stanley Holton, Sandra. "Family Memory, Religion and Radicalism: The Priestman, Bright, and Clark Kinship Circle of Women Friends and Quaker History." Quaker Studies 9, no. 2, (2005): 156175.

Stone, Lawrence. The Family, Sex, and Marriage. London: Harper \& Row Publishers, 1977.

Sussman, Charlotte. Consuming Anxieties: Consumer Protest, Gender, and British Slavery, $1713-$ 1833. Stanford: Stanford University Press, 2000.

Taylor, Norma. "Life of Mary Anne Rawson.” BA Dissertation, Sheffield University, 1972. 
Thompson, David M., ed. Nonconformity in the Nineteenth Century. London: Routledge and Kegan Paul, 1972.

Timm, Annette F. and Joshua A Sanborn. Gender Sex and the Shaping of Modern Europe: A History from the French Revolution to the Present Day. Oxford: Berg Publishers, 2007.

Tosh, John. A Man's Place: Masculinity and the Middle-Class Home in Victorian England. New Haven: Yale University Press, 1999.

Tosh, John. "The History of Masculinity: An Outdated Concept?" In What Is Masculinity? Historical Dynamics from Antiquity to the Contemporary World, edited by John Arnold and Sean Brady. Basingstoke, Hampshire: Palgrave Macmillan, 2011.

Tosh, John. "The Old Adam and the New Man: Emerging Themes in the History of English Masculinities, 1750-1850.” In English Masculinities, 1660-1800, edited by Tim Hitchcock and Michèle Cohen. London: Routledge, 2016.

Trivallato. Francesca. The Promise and Peril of Credit: What a Forgotten Legend About the Jews and Finance Tells Us About the Making of European Commercial Society. Princeton: Princeton University Press, 2019.

Tudur Jones, R. Congregationalism in England, 1662-1962. London: London Independent Press Ltd., 1962.

Turley, David. The Culture of English Anti-Slavery, 1780-1860. London: Routledge, 1991.

Tweedale, Geoffrey. "Backstreet Capitalism: An Analysis of the Family Firm in the NineteenthCentury Sheffield Cutlery Industry.” Business History 55, no. 6 (2013): 875-91.

Twells, Alison. The Civilising Mission and the English Middle Class, 1792-1850: The Heathen at Home and Overseas. Basingstoke, Hampshire: Palgrave Macmillan, 2009.

Twells, Alison. 'Let Us Begin Well at Home': Class, Ethnicity, and Christian Motherhood in the Writing of Hannah Kilkam, 1774-1833." In Radical Femininity: Women's Self-Representation in the Public Sphere, edited by Eileen Yeo. Manchester: Manchester University Press, 1998.

Twells, Alison. "Missionary Domesticity, Global Reform, and the 'Woman's Sphere' in Early Nineteenth-Century England.” Gender and History 18, no. 2 (2006): 266-84.

Twells, Alison. 'We Ought to Obey God Rather than Man': Women, Anti-Slavery, and Nonconformist Religious Cultures, 1800-1840." In Women, Dissent, and Anti-Slavery in Britain and America, 1790-1865, edited by E. J. Clapp and J .R. Jeffrey. Oxford: Oxford University Press, 2011. 
Van Horn Melton, James. Rise of the Public in Enlightenment Europe. Cambridge: Cambridge University Press, 2001.

Vickery, Amanda. The Gentleman's Daughter: Women's Lives in Georgian England. New Haven: Yale University Press, 1998.

Wahrman, Dror. Imagining the Middle Class: The Political Representation of Class in Britain, $c$. 1780-1840. Cambridge: Cambridge University Press, 1995.

Wahrman, Dror. 'Middle Class' Domesticity Goes Public: Gender, Class, and Politics from Queen Caroline to Queen Victoria." Journal of British Studies 32, no. 4 (1993): 396-432.

Waller, Altina L. Feud: Hatfields, McCoys, and Social Change in Appalachia, 1860-1900. Chapel Hill: University of North Carolina Press, 1988.

Weiss, Barbara. The Hell of the English: Bankruptcy and the Victorian Novel. Lewisburg: Bucknell University Press, 1986.

Williams, Carolyn D. and Angela Escott, and Louise Duckling. Woman to Woman: Female Negotiating During the Long Eighteenth Century. Newark: University of Delaware Press, 2010.

Wilson, Kathleen. The Island Race: Englishness, Empire, and Gender in the Eighteenth Century. New York: Routledge, 2003.

Wilson, Kathleen. "Languages of Class, Practices of Power." Journal of Urban History 25, no. 4 (1999): 557-70.

Wilson, Kathleen. Sense of the People: Politics, Culture, and Imperialism in England, 1715-1785. Cambridge: Cambridge University Press, 1998.

Wilson, R. E. Two Hundred Precious Metal Years: A History of the Sheffield Smelting Company Limited 1760-1960. London: Ernest Benn Limited, 1960.

Yanagisako, Sylvia. "Bringing It All Back Home: Kinship Theory in Anthropology." In Kinship in Europe: Approaches to Long-Term Development (1300-1900), edited by David Warren Sabean, Simon Teuscher, and Jon Mathieu. New York: Berghahn Books, 2007.

Zall, P.M. "The Cool World of Samuel Taylor Coleridge: Joseph Lancaster's System.” The Wordsworth Circle 13, no. 2 (1982): 91-93. 
